\title{
제29차 국제개발협력위원회
}

의 결안건(제 29-1호)

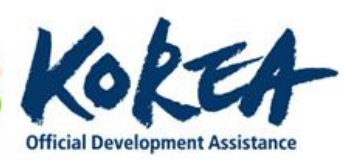

\section{'18년 국제개발협력 종합시행계획 [요구액 기준]}

\section{6. 30}

※ 동 안건에 포함된 $\mathrm{ODA}$ 사업은 요구 기준이며, 정부예산 편성과정 및 국회 예산 심의를 통해 최종 확정 예정임

\section{관계부처 합동}




\section{순 서}

।. 추진배경

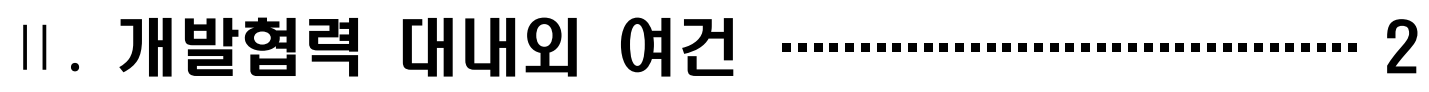

III. 새 정부 국제개발협력 추진방향 …………… 3

IV. '18년 국제개발협력 추진방향 ………………. 5

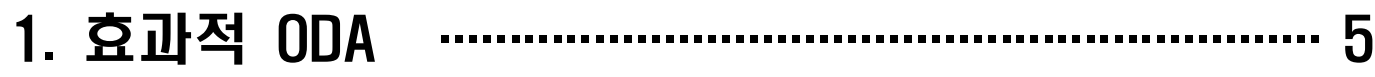

2. 투명한 ODA ……………………………………...... 19

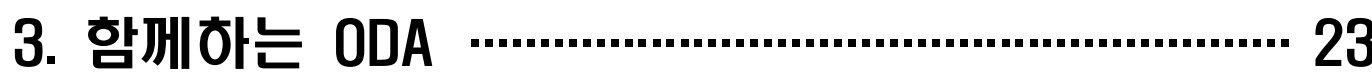

V. '18년 국제개발협력 사업 개요 …………..... 28

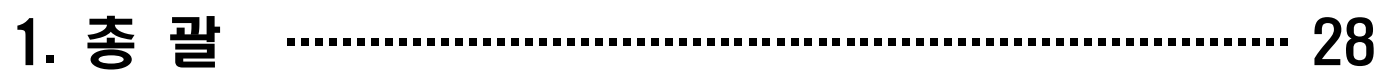

2. 양자협력 분야 ……................................................... 31

3. 다자협력 분야 ………………………………......... 32

〈첨부 1〉 2018년도 기관별 ODA 사업예산 현황 …………. 33 〈첨부 2〉 2018년도 기관별 ODA 사업예산 세부현황 …….. 34 


\section{I. 추진 배경}

$\square$ 국제개발협력위원회는 유상·무상 분야별 시행계획을 조정 · 심사·의결하여 매년 ‘종합시행계획'을 확정

* 국제개발협력기본법 제 11 조 및 동 시행령 제9조

O 금년은 $\mathrm{ODA}$ 를 둘러싼 대내외 여건 진단 등을 통해 새 정부의 추진방향을 설정하고 차년도 사업 추진방향을 제시

* $\triangle \mathrm{ODA}$ 사업의 투명성·체계성·효과성 확보 $\Delta$ 일자리창출 연계·민간협력 등

$\square$ 금번 종합시행계획(안) 의결 결과는 정부 예산 편성 및 국회 예산 심의 과정을 거쳐 12 월말 확정액 기준 시행계획에 반영·확정 (국제개발협력위원회)

< 참고 : 국제개발협력 종합시행계획 수립 절차 >

○ 시행기관, 「기관별 시행계획안」 수립(3월)

○ 주관기관, 기관별 시행계획안 검토 후「분야별 시행계획안」을 수립 하여 국제개발협력위원회에 제출(5월)

윽ㄱㄱㄱ개발협력위, 분야별 시행계획(유무상 사업심사 포함) 검토 후, $\ulcorner$ 연간 종합시행계획」 수립·의결(6월)

의예산안 편성 및 심의(기재부·국회)

○ 국제개발협력위, 확정예산 반영한「연간 종합시행계획」 의결(12월) 


\section{II. 개발협력 대내외 여건}

\section{$\square$ 대 외}

O '15.9월 유엔 개발정상회의에서 채택된 '2030 지속가능개발 의제(SDGs")' 이행노력 본격화, 국제적으로 취약국·계층에 대한 지원 확대 요구 증대

* SDGs는 사회·환경·경제를 3 대 축으로 포괄적이고 다원화된 개발 목표 제시

우리도 국제사회에서 높아진 위상만큼 지원과 책임을 요구받고 있으나, 충분하지는 않은 상황

- SDGs 등 국제적·보편적 가치 및 목표에 중점을 둔 사업집행 필요

- ODA 규모도 기본계획상 목표('20년까지 ODA/GNI 비율 0.2\%) 달성을 위해 지속 확대 요구

* ODA/GNI 비율 '16년 실적은 $0.14 \%$ 수준

\section{$\square$ 대 내}

외최근 $\mathrm{ODA}$ 예산의 지속적인 증가에 따라 $\mathrm{ODA}$ 투명성 - 책임성· 효과성 강화 요구 증대

* ('13) 1.9 조원 $\rightarrow$ ('15) 2.2조원 $\rightarrow$ ('17) 2.6조원

- 일부 사업은 ODA원칙에 부합하지 않았다는 우려로 국민 신뢰 저하

- 해외 현지에서 진행되는 관계로 집행과정의 부실 사례 발생

엉부북관의 $\mathrm{ODA}$ 추진과정에서 민간부문과의 협력 강화, $\mathrm{ODA}$ 생태계 육성을 통한 일자리 기여 등 요구

$\diamond$ 국제적 · 보편적 가치에 목표를 둔 원칙있는 $\mathrm{ODA}$ 를 통해 국민 신뢰 회복 및 국제사회에 기여 추진 


\section{III. 새 정부 국제개발협력 추진방향}

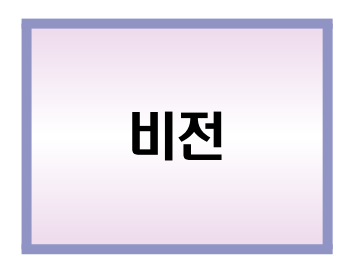

\section{인류의 공동번영과 세계평화에 기여}

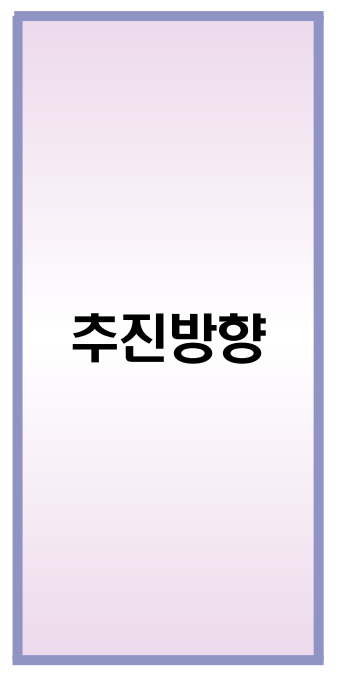

\section{SDGS 이행목표 달성에 기여하는 원칙있는 ODA}

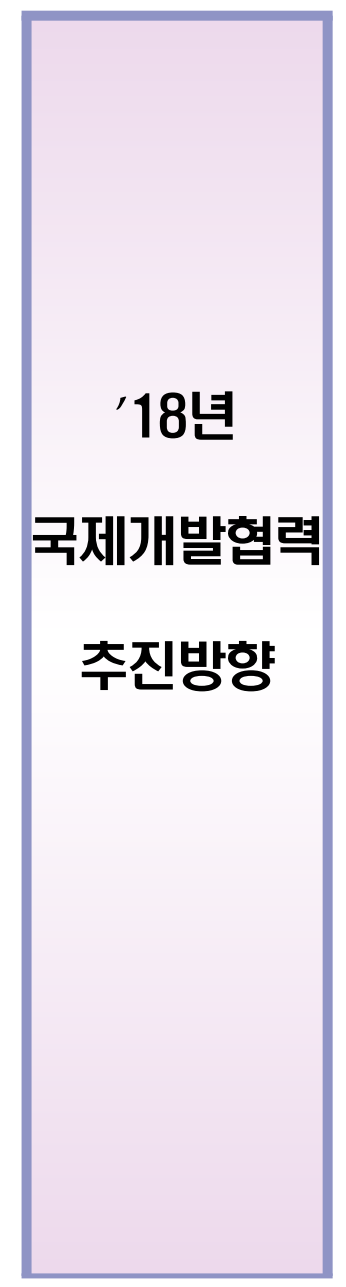

2 국가협력전략에

기반한 사업 추진

3 ODA 사업간 연계 및

평가 내실화
2 수요자 친화적 정보공개 확대

3 범국민 이해와 참여 증진
함께하는 ODA

1 ODA 생태계

육성 통한일지리

기여 및 만간과

파트너십 강화

2 인도적 지원 단계적 확대

3 글로벌 파트너십 강화 


\section{새 정부 국제개발협력 추진방향}

\section{1 효과적 $\mathrm{ODA}$}

ㅇ 그간 국제 공통의 가치.수요 등 일관된 방향下 ODA 추진 미흡 $\rightarrow$ 지원에 따른 효과 미흡, 원칙 없는 ODA로 비판

* 예) 한식 - 한류문화 전파 사업 $\rightarrow$ 개도국이 필요로 하는 지원을 해야 하는 ODA사업의 성격에 맞지 않고 현지화도 곤란

아다수 기관이 참여하지만 상호 연계가 되지 않고 단순 난립 한다는 비판 지속 $\rightarrow$ 수원국이 원하는 목적에 기여 곤란

$\Rightarrow$ 국제사회 공동 목표(SDGs), 수원국 수요(국가협력전략) 등을 재원배분 원칙으로 설정하고, 사업간 연계방식 활성화 등 원조효과성 제고

\section{2 투명한 ODA}

○ 예산규모는 증가하지만 해외현지 진행사업에 대한 통제 메카니즘은 미흡 $\rightarrow$ 부적절한 사업추진 가능성

$\Rightarrow$ 사업과정의 정보공개 확대, 현장점검 강화 등 제도적 장치를 설정하여 우리국민 및 수원국에 대한 투명성·책임성 확보

\section{3 함께하는 ODA}

인간역량을 활용한 시너지 효과 제고, $\mathrm{ODA}$ 의 생태계 육성을 통한 일자리 기여, 글로벌 협력을 통한 국가 위상 제고 등 요구

$\Rightarrow$ 민간부문, 타공여국, 국제기구 등 $\mathrm{ODA}$ 주체와의 소통과 협력을 지속 강화

$\diamond$ 원칙있는 $\mathrm{ODA}$ 로 국민 신뢰 기반 마련 및 SDGs 이행 목표 달성에 기여 


\section{IV. '18년 국제개발협력 추진방향}

\section{1 효과적 ODA}

\section{1 개도국 SDGS 이행 지원}

$\square$ 개 요

ㅇㄱㄱ제사회가 공동으로 추구하는 개도국의 SDGs 이행 지원을 $\mathrm{ODA}$ 재원배분 및 사업추진 핵심 원칙으로 적용

- 핵심원칙에 부합되지 않는 등 논란이 있었던 기존 일부사업들은 정비

* 코리아에이드 : 사업 既폐기, 보건사업(모자보건 아웃리치사업)으로 대체

* 새마을 ODA : 개도국 특성 고려없이 과도하게 추진한 사업은 수원국 맞춤형 사업으로 추진 (새마을 분과위 등 추진체계 폐지)

* 개발협력구상 : 관련사업은 SDGS 이행 지원사업으로 추진(명칭 및 추진체계 폐지)

이배별사업 기획 과정에서 $\mathrm{SDGs}$ 와의 연계성 검토 및 이행 지원을 위한 성과지표 설정

\section{$\square$ 주요 지원 분야 및 사업}

○ ' 18 년 관련 사업 규모는 약 2 조 4,719 억원, 17 개 목표 중 우리의 비교 우위 분야인 산업화, 교육, 보건, 물과 위생, 기아와 농업에 집중 배분(약 1 조 7,019 억원)

* SDGs 17개 목표

(1)빈곤퇴치 (2)기아와 농업 (3)보건 (4)교육 (5)양성평등 (6)물과 위생 (7)에너지 (8)포용적 경제성장 (9)산업화 (10)불평등 (11)지속가능도시 (12)지속가능소비생산 (13)기후변화 (14)해양자원 (15)생물다양성 - 생태계 (16)평화 - 제도 (17)이행수단 · 글로벌파트너십 
- (산업화, SDG 9) 철도, 도로, 통신망 등 사회기반시설 지원 * 베트남 로떼-락소이 고속도로 건설사업(EDCF) 등

- (교육, SDG 4) ICT 기반 교육시스템, 정보화 지원 등 양질의 교육 지원 * 파키스탄 UNESOO 소녀들의 교육권 현실화를 위한 교육역량 강화 지원사업(KOCA) 등

- (보건, SDG 3) 종합병원, 보건역량강화 지원 등 전반적 의료 환경 개선

* 우즈베키스탄 국립아동병원 건립사업( $(E D F)$, WHO 향생제내성 등 신규 감염병 대응을 위한 국가 대응능력 향상사업 (KOICA) 등

- (물과 위생, SDG 6) 상-하수처리 식수시설 등 수자원 안전 및 위생 개선 * 우간다 UNICEF 카라모자 지역 초중등학교 식수시설 보급 및 위생교육 사업(KOICA) 등

- (기아와 농업, SDG 2) 농촌 종합개발 사업, 농업기술 전수사업 등을 통해 개도국 농촌의 자립도 제고

* 수원국에 특화된 영농기술 전수사업(농식품부) 등

< SDG 목표와 ODA 사업규모 >

\begin{tabular}{|c|c|c|c|c|c|c|c|c|c|c|c|c|c|c|c|c|c|c|}
\hline 목 표 & 그분 & 1 & 2 & 3 & 4 & 5 & 6 & 7 & 8 & 9 & 10 & 11 & 12 & 13 & 14 & 15 & 16 & 17 \\
\hline \multirow{3}{*}{$\begin{array}{c}\text { 사업 } \\
\text { 수 } \\
\text { (개) }\end{array}$} & 구상 & 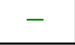 & 8 & 17 & 9 & - & 26 & 9 & - & 38 & 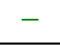 & 1 & - & 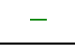 & - & - & 3 & - \\
\hline & 무상 & 53 & 129 & 138 & 203 & 14 & 46 & 24 & 68 & 120 & 12 & 54 & 5 & 45 & 23 & 20 & 138 & 63 \\
\hline & 총계 & 53 & 137 & 155 & 212 & 14 & 72 & 33 & 68 & 158 & 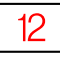 & 58 & & 45 & 23 & 20 & 141 & 63 \\
\hline \multirow{3}{*}{$\begin{array}{l}\text { 규모 } \\
\text { (억원) }\end{array}$} & 유상 & 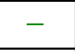 & 586 & 1,356 & 749 & - & 1,901 & 727 & - & 4,897 & - & 180 & + & $\pi$ & - & 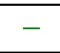 & 185 & - \\
\hline & 무상 & 198 & 1,461 & 1,453 & 3597 & 965 & 324 & 310 & 425 & 697 & 70 & 307 & 8 & 261 & 184 & 155 & 760 & 969 \\
\hline & 총계 & 1,193 & 2,047 & 2808 & 4,346 & 965 & 2725 & 1,037 & 425 & 5,594 & 70 & 487 & 8 & 1,261 & 184 & 156 & 945 & 969 \\
\hline \multirow{3}{*}{$\begin{array}{c}\text { 비중 } \\
(\%)\end{array}$} & 유상 & - & 6 & 13 & 7 & - & 18 & 7 & - & 46 & - & 2 & - & - & - & - & 2 & - \\
\hline & 무상 & 84 & 10.3 & 10.3 & 25.4 & 6.8 & 23 & 22 & 3.0 & 4.9 & 0.5 & 22 & 0.1 & 8.9 & 1.3 & 1.1 & 5.4 & 6.9 \\
\hline & 총계 & 4.8 & 8.3 & 11.4 & 17.6 & 3.9 & 9.0 & 4.2 & 1.7 & 226 & 0.3 & 20 & 0.0 & 5.1 & 0.7 & 0.6 & 3.8 & 3.9 \\
\hline
\end{tabular}

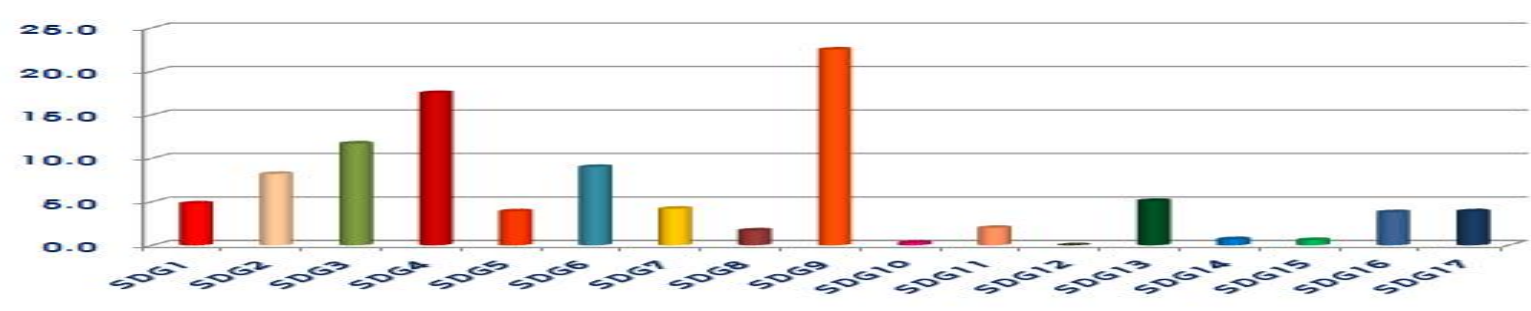

\section{향후 추진계획}

O 주요 공여국의 정책 및 전략 분석, SDGs 목표별 성과관리 프레임워크 도출 등 체계적인 이행 지원 전략 마련

* 금년 평가소위 과제로 「개도국의 SDGs 이행 지원 평가」진행 예정 


\section{2 국가협력전략에 기반한 사업 발굴·추진}

\section{$\square$ 개 요}

우수원국과 협의를 통해 수원국 수요를 반영하여 작성된 국가 협력전략(CPS)을 사업 발굴과 재원배분의 우선 기준으로 설정

* 선택과 집중을 통한 원조 효과성 제고를 위해 양자 ODA 재원을 24개 중점 협력국 및 중점협력국별 중점협력 분야(교통, 수자원, 의료 등)에 집중 지원

\section{중점협력국 및 중점협력분야 지원현황}

으웅점협력국 지원 액: 총 1 조 2,692억원 (양자 ODA재원의 $72.6 \%$ )

- (유상원조) 8,486억원 (총 유상지원액 1조 581억원의 80.2\%)

- (무상원조) 4,206억원 (개별국가 대상 ${ }^{*}$ 원조액 6,889억원의 61.0\%) * 양자 무상원조 사업 중 개별 국가 대상 사업

으웅점협력국 중점협력분야 지원액: 총 1 조 580 억원 (중점협력국 지원 총액의 $83.3 \%$ )

- (유상 원조) 7,487억원 (중점협력국 유상 지원 총액의 88.2\%)

- (무상 원조) 3,093억원 (중점협력국 무상 지원 총액의 73.5\%)

\section{$\square$ 향후 추진계획}

이수원국 국가발전 전략과 우리나라의 원조역량을 고려한 국별협력 전략에 따라 사업을 발굴, 기획할 수 있도록 시행기관 협조 강화

ㅇ 수원국 수요와 상황에 탄력 대응하기 위한 CPS 수립 개선방안 마련 


\section{참고 중점협력국 및 중점협력분야 현황}

\section{중점협력국별 중점협력분야 목록}

\begin{tabular}{|c|c|}
\hline 중점협력국 & 중점협력분야 \\
\hline 가나 & 지역개발, 보건위생, 교육, 에너지 \\
\hline 네 팔 & 물관리 및 보건위생, 교육, 지역개발, 에너지 \\
\hline 라오스 & 물관리 및 보건위생, 에너지, 교육, 지역개발 \\
\hline 르 완다 & 통신, 교육, 지역개발 \\
\hline 모잠비크 & 교통, 에너지, 물관리 및 보건위생, 교육 \\
\hline 몽골 & 교육, 물관리 및 보건위생, 공공행정, 교통 \\
\hline 미얀마 & 공공행정, 지역개발, 교통, 에너지 \\
\hline 방글라데시 & 교육, 교통, 물관리 및 보건위생, 통신 \\
\hline 베트남 & 교통, 교육, 물관리, 공공행정 \\
\hline 볼리비아 & 지역개발, 물관리 및 보건위생, 교통, 에너지 \\
\hline 세네갈 & 지역개발 및 수산업, 교육, 물관리 및 보건위생, 교통 \\
\hline 스리랑카 & 교육, 교통, 물관리 및 보건위생, 지역개발 \\
\hline 아제르바이잔 & 통신 공공행정, 물관리 및 보건위생, 지역개발 \\
\hline 에티오피아 & 물관리 및 보건위생, 지역개발, 교통·에너지, 교육 \\
\hline 우간다 & 지역개발, 교육, 물관리 및 보건위생 \\
\hline 우즈베키스탄 & 공공행정, 교육, 물관리 및 보건위생 \\
\hline 인도네시아 & 교통, 환경보호, 공공행정, 물관리 및 보건위생 \\
\hline 캄보디아 & 교통, 물관리 및 보건위생, 교육, 지역개발 \\
\hline 콜롬비아 & 평화구축, 교통, 산업, 지역개발 \\
\hline 탄자니아 & 물관리 및 보건위생, 교통, 교육, 에너지 \\
\hline 파라과이 & 물관리 및 보건위생, 교통, 통신, 지역개발 \\
\hline 파키스탄 & 교통, 에너지, 물관리 및 보건위생, 지역개발 \\
\hline 페루 & 보건위생, 공공행정, 환경보호, 교통 \\
\hline 필리핀 & 지역개발, 물관리 및 보건위생, 교통, 재해예방 \\
\hline
\end{tabular}




\section{ODA 사업간 연계 및 평가 내실화}

\section{3-1 ODA 사업간 연계 및 통합적 추진}

\section{$\square$ 개 요}

ㅇ 실제 시너지 효과를 낼 수 있는 ${ }^{1}$ 사업간 연계, 과감한 통폐 합에 중점을 둔 ${ }^{(2)}$ 유사 - 중복사업간 조정 등 종합조정

○ 유상-무상 사업간 14 건(38개 사업) 연계, 무상사업간 13 건(29개 사업) 연계, 사업간 중복방지 10 건(21개 사업) 추진

\section{$\square$ 연계 및 중복방지}

\section{(1) 유상-무상 사업간 연계 [14건 38개 사업]}

유상-무상 사업이 전후방으로 연계되어 수원국 목표 달성에 종합적으로 기여할 수 있도록 사업간 연계

$<$ 예시 $>$

i ) 개 발조사 (무상) + 인프라(유상) + 역량강화(무상)

: 타슈켄트 공항 신여객터미널 건설 타당성 조사(무상, $\mathrm{KOICA})$

+ 타슈켄트 공항 신여객터미널 건설 사업(유상, EDCF)

+ ICAO 공동연수-공항건설 및 운영과정(무상, $\mathrm{KOICA})$

$+\mathrm{ICAO}$ 공동연수-공항포장평가(무상, $\mathrm{KOICA})$

$\Rightarrow$ 무상사업으로 타당성 조사 실시 $\rightarrow$ 그 결과를 토대로 유상 건설 사업 추진 $\rightarrow$ 무상사업으로 공항 운영 및 관리 기술 전수

ii ) 인 프라(유상) + 역량강화(무상)

: 우즈베키스탄 교육정보화 1차 사업(유상, EDCF)

+ UNESCO 아태지역 저개발국 ICT 활용교육 지원(무상, 교육부)

+ 우즈벡 교육정보화 지원(무상, 교육부)

$\Rightarrow \mathrm{EDCF}$ 사업으로 전국 학교에 컴퓨터 교실 설치 완료 $\rightarrow$ 교육부 사업으로 교사 ICT 활용역량 제고 및 기자재(PC, 노트북 등) 지원 


\section{(2) 무상 사업간 연계 [13건 29개 사업]}

으타 기관 사업으로 지원한 인프라, 교육·기술 컨텐츠 등을 활용하여 사업효과성 제고

<예시>

- 카메룬 벼 재배단지를 활용한 교육연구단지 조성사업(무상, 농식품부)

+ 한-아프리카 농식품 기술협력협의체 운영(무상, 농진청)

$\Rightarrow$ 농진청 사업으로 아프리카에 적합한 벼 품종 개발, 농식품부 연구단지 조성 사업에 농진청이 개발한 벼 품종 활용

\section{(3) 사업간 중복방지 [10건 21 개 사업]}

유유사 중복 가능성 있는 사업에 대해 과감한 통폐합 추진 * 21 개 사업을 10 개 사업으로 통폐합

$<$ 예시 $>$

i ) 베트남 연안지역 통합해양 환경관리 기반구축(무상, 해수부)

+ 대규모 해양오염 대비를 위한 국가방제체계 구축 지원사업(무상, 안전처)

+ 베트남 연안관리 및 해양오염 대응 이행전략 수립(무상, $\mathrm{KOICA}$ )

$\Rightarrow$ 베트남 연안관리 및 해양오염 대응 이행전략 수립(KOICA)으로 통폐합

ii ) 케냐 해외농업기술개발 2차 사업(무상, 농진청)

+ 케냐 양계·감자 KOPIA 시범마을 조성사업(무상, 농진청)

$\Rightarrow$ 케냐 해외농업기술개발 2차 사업(농진청)으로 통폐합

\section{$\square$ 향후 추진 계획}

ㅇ 종합패키지형 연계 사업 강화

- 사업간 전후방 연계 유형(인프라 구축 $\rightarrow$ 역량강화, 사후관리 기자재 등) 적극 유도 $\rightarrow$ 수원국의 목적 달성에 실질적으로 기여

* 예) 000 국의 '보건인프라 확립' 목적 달성을 위해서는 '병원건립' + '의료기기' + '운 영지원’ + ‘의료인력 초청연수’ + ‘의료기기 사후관리’ 등의 종합 지원 필요 
< 패키지 사업의 유형 >

- (유형 1) 개발조사(무상) + 인프라(유상)

예) 무상으로 공항 여객터미널 건설 타당성조사 시행, 유상으로 건설 추진

- (유형 2) 시설지원(무상) + 역량강화(무상)

예) 무상으로 농촌개발을 위한 시설(양계장 등) 지원, 무상으로 기술자문 및 교육 제공

- (유형 3) 인프라(유상) + 시설지원(무상)

예) 유상으로 대형병원 건립, 무상으로 의료기자재를 공급

- (유형 4) 인프라(유상) + 역량강화(무상)

예) 유상으로 철도현대화 사업 추진, 무상으로 철도 교관요원 역량강화 병행

- (유형 5) 인프라(유상) + 시설지원(무상) + 역량강화(무상)

예) 유상으로 병원 건립, 무상으로 의료기자재 지원, 무상으로 의료인력 초청연수

i) 연중 상시 발굴 체계 가동( (가칭)유무상 연계협의회 운영)

ii) 국제개발협력위원회 심의 및 예산당국의 예산편성 과정에서 연계사업에 대해 우선고려

- 특히, 신규사업 제안시 기존/신규 사업과의 연계 필수적 검토 유도 * 금년은 신규 478 개 사업중 17 개 사업 연계(교육부 6 개, EDCF 4개)

iii) 기 연계 추진사업에 대해서도 추진현황 및 실적 점검

\section{3-2 평가결과의 실질적 활용을 위한 평가제도 전면 재설계}

ㅇ 평가보고서 품질을 향상시키고 성과지향적 평가를 유도하여 궁극적 으로 평가결과와 차년도 사업심사가 연계될 수 있는 체계 구축

* 현재는 기관간 평가 품질에 차이 크고, 차년도 심사에 연계되는 매커니즘 부재

i ) 평가 품질 향상을 위해 사업유형별 평가기준 및 지표 마련

ii) 사업별 성과지표 설정 및 그 달성여부를 중점 평가

iii) 평가결과와 차년도 사업심사간 연계 매커니즘 구축 


\section{참고 2018년도 사업간 연계 및 통합 세부내역}

\section{1. 연계추진 : 27건 [67개 사업]}

\section{(1) 유무상간 연계 - 14건 [38개사업]}

\begin{tabular}{|c|c|c|c|c|c|}
\hline & 기관 & 사 업 명 & 수원국 & 조정결 과 & 내 용 \\
\hline \multirow{4}{*}{1} & EDCF & $\begin{array}{l}\text { 타슈ㅋㅔㅔㅌㅡ 국제공항 신여ㄱㅐㅐ터미널 건설사업 } \\
\text { (프로젝트, '17년-'20년, 487억/2,291억, 신규) }\end{array}$ & \multirow{2}{*}{$\begin{array}{l}\text { 우즈베 } \\
\text { 키스탄 }\end{array}$} & \multirow{4}{*}{ 연계추진 } & $\begin{array}{l}\text { 개발조사(무상) }+ \text { 인프라(유상) }+ \text { 역량 } \\
\text { 강화(무상) }\end{array}$ \\
\hline & \multirow{3}{*}{ KOICA } & $\begin{array}{l}\text { 타슈ㅋㅔㅔㅌㅡ 공항 신여객터미널 건선 타당성조사 } \\
\text { (개발컨설팅, "15년-'17년, } 41 \text { 억, 완료) }\end{array}$ & & & $\begin{array}{c}\text { ○ 무상사업인 KOICA의 타슈켄트 공항 신여객 } \\
\text { 터미널 건설 타당성 조사결과를 토대로 } \\
\text { 유상사업인 EDCF의 타슈켄트 국제공항 신여객 }\end{array}$ \\
\hline & & $\begin{array}{l}\text { ICAO 공동연수-공항건설 및 운영과정 } \\
\text { (연수사업, '17년-'19년, 1.6억/4.8억, 계속) }\end{array}$ & \multirow{2}{*}{$\begin{array}{l}\text { ICAO } \\
\text { 회원국 }\end{array}$} & & \multirow{2}{*}{$\begin{array}{l}\text { O EDCF의 공항 터미널 사업 수원국 관계자 } \\
\text { (공항건설 담당자)를 ICAO 연수대상에 포함, } \\
\text { 공항건설 · 운영 및 시설관리 등을 전수하여 } \\
\text { 공항 터미널의 성공적 건설에 기여 } \\
\text { * 연수대상 선정 시 ICAO와 협의 }\end{array}$} \\
\hline & & $\begin{array}{l}\text { ICAO 공동연수-공항포장평가(인증) } \\
\text { (연수사업, '17년-'19년, 1.6억/4.8억, 계속) }\end{array}$ & & & \\
\hline \multirow{3}{*}{2} & EDCF & $\begin{array}{l}\text { 공안부 현대식병원 건립사업 } \\
\text { (프로젝트, "17년-'23년, 6억/745억, 계속) }\end{array}$ & \multirow{3}{*}{ 라오스 } & \multirow{3}{*}{ 연계추진 } & \multirow{3}{*}{$\begin{array}{l}\text { - 인프라(유상) + 역량강화(무상) } \\
\text { ○ EDCF 사업으로 병원 건축, 의료기자재 등을 지원 } \\
\text { ○ KOICA 사업으로 해당병원의 전문의 양성을 } \\
\quad \text { 위한 국내 전문가 파견 및 초청연수 } \\
\text { } \mathrm{KOFIH} \mathrm{사업으로} \mathrm{해당병원에서} \mathrm{의료기기를} \\
\text { 취급하는 기술인력을 교육 }\end{array}$} \\
\hline & KOICA & $\begin{array}{l}\text { 경찰병원 역량강화사업 } \\
\text { (프로젝트, '14년-'18년, 10억/56억, 계속) }\end{array}$ & & & \\
\hline & $\begin{array}{l}\text { 복지부 } \\
(\mathrm{KOFIH})\end{array}$ & $\begin{array}{l}\text { 라오스 의료기기 관리운영체계 구축사업 } \\
\text { (프로젝트, '18년-'22년, 8억/50억, 신규) }\end{array}$ & & & \\
\hline \multirow{3}{*}{3} & EDCF & $\begin{array}{l}\text { 르완다 국립대학교 건립사업 } \\
\text { (프로젝트, '15년-'20년, 171억/701억, 계속) }\end{array}$ & \multirow{3}{*}{ 르완다 } & \multirow{3}{*}{ 연계추진 } & \multirow{3}{*}{$\begin{array}{l}\text { 인프라(유상) + 역량강화(무상) } \\
\text { EDCF 사업으로 르완다 국립대학교 건립 } \\
\text { O 교육부의 유네스코 인재양성지원을 통해 } \\
\text { 르완다 국립대학교에 창업지원 관련 교육 } \\
\text { 과정 개설을 지원하고 강의(교수진 파견) } \\
\text { 교육부의 국제협력 선도대학 사업으로 르완다 } \\
\text { 국립대학교의 원격교육 학부 교육과정 개편, } \\
\text { 교재개발, 교원양성 등 지원 }\end{array}$} \\
\hline & \multirow{2}{*}{ 교육부 } & $\begin{array}{l}\text { 유네스코 저개발국 인재양성지원 - UNITWIN } \\
\text { (기타기술협력, '15년-'19년, 20억/90억, 계속) }\end{array}$ & & & \\
\hline & & $\begin{array}{l}\text { 국제협력 선도대학 육성지원사업 } \\
\text { - 르완다대학교 원격교육 역량강화사업 } \\
\text { (민관협력, '18년-'23년, 4억/18억, 계속) }\end{array}$ & & & \\
\hline \multirow[b]{2}{*}{4} & EDCF & $\begin{array}{l}\text { 요르단 연구용 원자로 건설사업 } \\
\text { (프로젝트, '10년-'16년, 960억, 완료) }\end{array}$ & \multirow[b]{2}{*}{ 요르단 } & \multirow[b]{2}{*}{ 연계추진 } & \multirow{2}{*}{$\begin{array}{l}\text { - 인프라(유상) }+ \text { 역량강화(무상) } \\
\text { EDCF 사업으로 건설된 연구용 원자로의 } \\
\text { 활용 능력을 촉진하도록, 교육부의 국제협력 } \\
\text { 선도대학 사업으로 과학기술대 원자력학과 } \\
\text { 교육과정 개편, 교재개발, 원자력 전문인력 } \\
\text { 양성 등 리모델링 지원 }\end{array}$} \\
\hline & 교육부 & $\begin{array}{l}\text { 국제협력 선도대학 육성지원사업 } \\
\text { - 과학기술대학교 원자력학과 교육의 질 제고 } \\
\text { (민관협력, '18년-'23년, 4억/18억, 계속) }\end{array}$ & & & \\
\hline
\end{tabular}




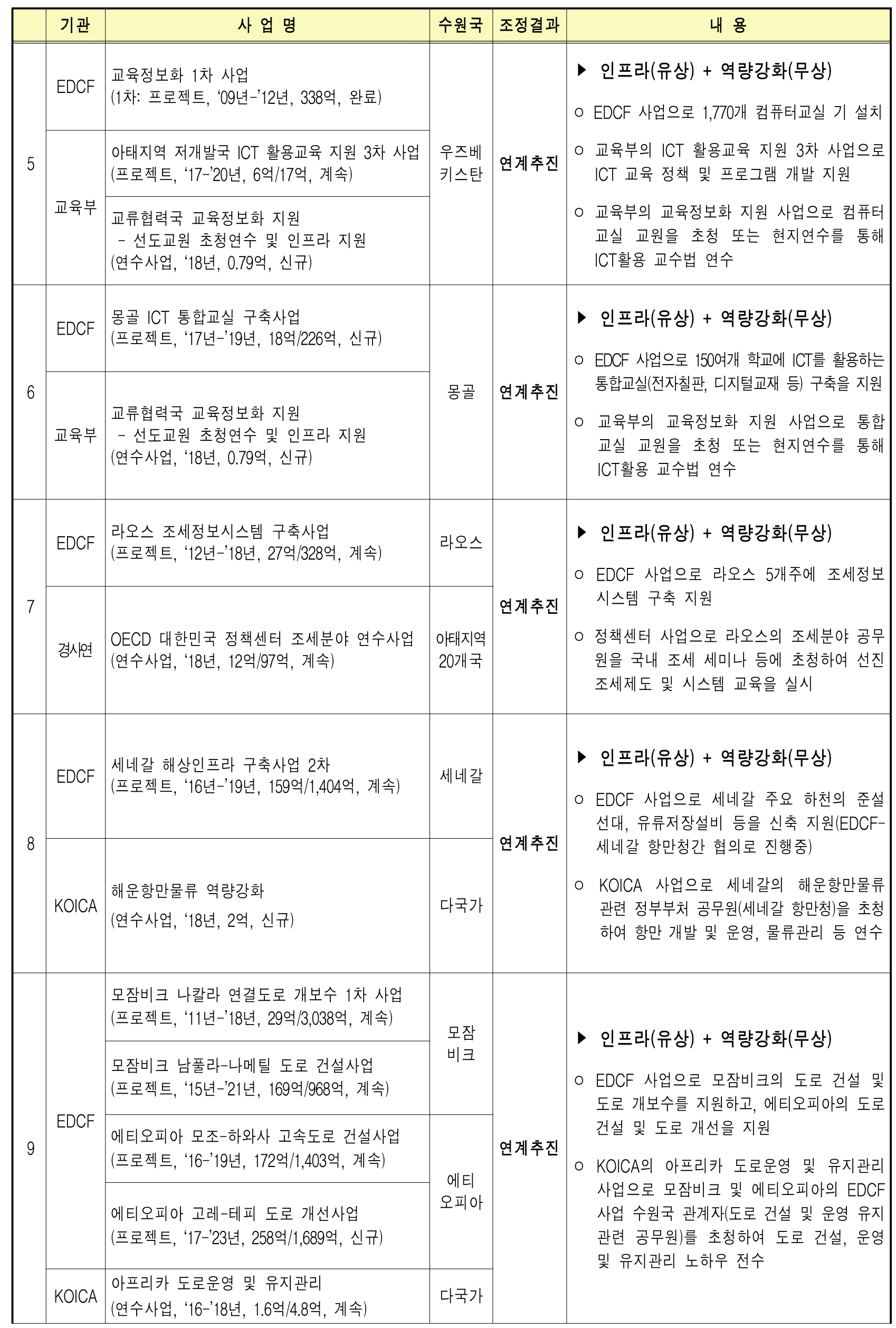




\begin{tabular}{|c|c|c|c|c|c|}
\hline & 기관 & 사 업 명 & 수원국 & 조정결 과 & 내 용 \\
\hline \multirow[b]{2}{*}{10} & EDCF & $\begin{array}{l}\text { 도미니카공화국 출입국 관리시스템 구축사업 } \\
\text { (프로젝트, '13-'19년, 13억/356억, 계속) }\end{array}$ & $\begin{array}{l}\text { 도미 } \\
\text { 니카 } \\
\text { 공화국 }\end{array}$ & \multirow[b]{2}{*}{ 연계추진 } & \multirow{2}{*}{$\begin{array}{l}\text { 인프라(유상) + 역량강화(무상) } \\
\text { ○ } \mathrm{EDCF} \text { 사업으로 출입국 수속 시간 단축을 } \\
\text { 위한 출입국 자동화 장비, 송수신 연계 시스템 } \\
\text { 구축 등 지원 } \\
\text { ○ } \mathrm{KOICA} \text { 의 출입국 관리행정 사업으로 수원국 } \\
\text { 관계자출입국관리 공무원)를 초청하여 출입국 } \\
\text { 시스템 구축 기술, 운영 및 서비스 노하우 전수 }\end{array}$} \\
\hline & KOICA & $\begin{array}{l}\text { 출입국 관리행정 역량강화 } \\
\text { (연수사업, '17-'19년, 1.6억/4.8억, 계속) }\end{array}$ & 다국가 & & \\
\hline \multirow[b]{2}{*}{11} & EDCF & $\begin{array}{l}\text { 방글라데시 BSM 의대 종합전문센터 건립사업 } \\
\text { (프로젝트, '16년-'20년, } 65 \text { 억/1,882억, 계속) }\end{array}$ & \multirow[b]{2}{*}{$\begin{array}{l}\text { 방글 } \\
\text { 라데시 }\end{array}$} & \multirow[b]{2}{*}{ 연계추진 } & \multirow{2}{*}{ 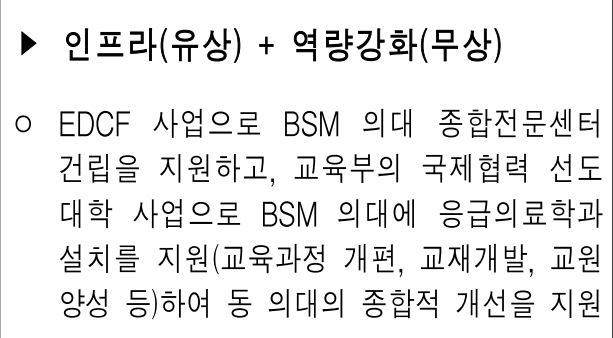 } \\
\hline & 교육부 & $\begin{array}{l}\text { 국제협력 선도대학 육성지원사업 } \\
\text { - BSM 의과대 교육역량강화사업 } \\
\text { (민관협력, '18년-'23년, 4억/18억, 계속) }\end{array}$ & & & \\
\hline \multirow{3}{*}{12} & \multirow{2}{*}{ EDCF } & $\begin{array}{l}\text { 전자정부 통합데이터센터 건립사업 } \\
\text { (프로젝트, '17년-'19년, 116억/309억, 계속) }\end{array}$ & \multirow{3}{*}{$\begin{array}{l}\text { 우즈베 } \\
\text { 키스탄 }\end{array}$} & \multirow{3}{*}{ 연계추진 } & \multirow{3}{*}{$\begin{array}{l}\text { 인프라(유상) + 역량강화(무상) } \\
\text { 을 EDCF 사업을 담당하는 수원국 공무원(정책 } \\
\text { 담당자)을 KOICA 사업 연수대상에 포함, } \\
\text { 전자정부 분야 정책 교육을 추진함으로써 } \\
\text { EDCF 사업으로 구축되는 센터 및 도서관 } \\
\text { 등의 성공적인 운영에 기여 }\end{array}$} \\
\hline & & $\begin{array}{l}\text { 국립전자도서관 구축사업 } \\
\text { (프로젝트, '15년-'18년, 75억/230억, 계속) }\end{array}$ & & & \\
\hline & KOICA & $\begin{array}{l}\text { 선임연구원 및 중간관리자를 위한 ICT 역량강화사업 } \\
\text { (연수사업, '17-'19년, } 1.6 \text { 억/4.8억, 계속) }\end{array}$ & & & \\
\hline \multirow[b]{3}{*}{13} & EDCF & $\begin{array}{l}\text { 탄자니아 주민증 데이터센터 건립사업 } \\
\text { (프로젝트, '14년-'19년, 2억/886억, 계속) }\end{array}$ & $\begin{array}{l}\text { 탄자 } \\
\text { 니아 }\end{array}$ & & \multirow{3}{*}{ 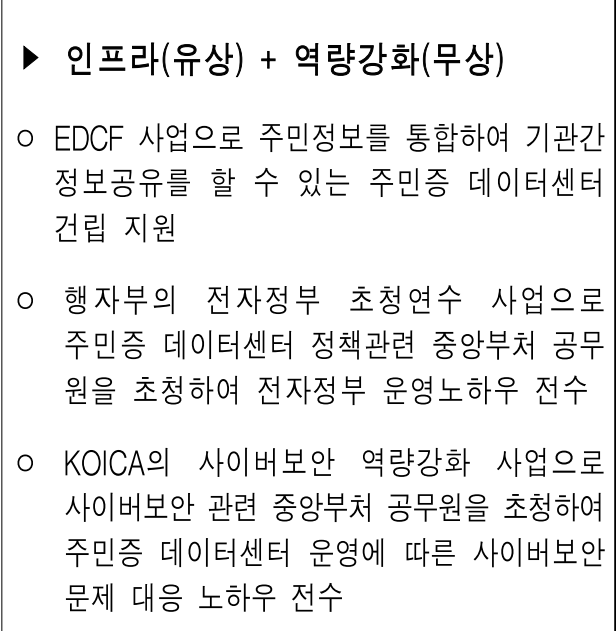 } \\
\hline & 행자부 & $\begin{array}{l}\text { 전자정부 초청연수 } \\
\text { (연수사업, '18년, 5억, 계속) }\end{array}$ & & & \\
\hline & KOICA & $\begin{array}{l}\text { 안정적인 e-gov 이행을 위한 사이버보안 역량 } \\
\text { 강화 } \\
\text { (연수사업, '18년, 2억, 신규) }\end{array}$ & 다국가 & 연계추진 & \\
\hline & EDCF & $\begin{array}{l}\text { 방글라데시 ICT 교육훈련센터 건립사업(2차) } \\
\text { (프로젝트, '17년-'20년, 10억/991억, 신규) }\end{array}$ & \multirow{2}{*}{$\begin{array}{l}\text { 방글 } \\
\text { 라데시 }\end{array}$} & \multirow{2}{*}{ 연계추진 } & \multirow{2}{*}{$\begin{array}{l}\text { - 인프라(유상) + 역량강화(무상) } \\
\text { ○ EDCF 사업으로 방글라데시 } 160 \text { 여개 면에 ICT } \\
\text { 교육을 담당할 중등교원 등 대상 ICT 교육훈련 } \\
\text { 센터 건립을 지원하고, 교육부의 교육정보화 } \\
\text { 지원 사업으로 방글라데시 해당지역의 교원을 } \\
\text { 초청 또는 현지연수를 통해 ICT활용 교수법 연수 }\end{array}$} \\
\hline & 교육부 & $\begin{array}{l}\text { 교류협력국 교육정보화 지원 } \\
\text { - 선도교원 초청연수 및 인프라 지원 } \\
\text { (연수사업, '18년, 0.79억, 신규) }\end{array}$ & & & \\
\hline
\end{tabular}


(2) 무상간 연계 - 13 건 [29개 사업]

\begin{tabular}{|c|c|c|c|c|c|}
\hline & 기관 & 사 업 명 & 수 원 국 & 조정결과 & 내 용 \\
\hline \multirow[b]{2}{*}{1} & $\begin{array}{l}\text { 농식 } \\
\text { 품부 }\end{array}$ & $\begin{array}{l}\text { 카메룬 벼 재배단지를 활용한 교육연구단지 } \\
\text { 조성사업 } \\
\text { (프로젝트. "14년-18년, } 6.5 \text { 억/30억, 계속) }\end{array}$ & 카메룬 & \multirow[b]{2}{*}{ 연계 추진 } & $\begin{array}{c}\text { ○ 농식품부의 사업으로 카메룬의 벼 품종개량 } \\
\text { 연구 등을 위한 연구단지 조성 지원 }\end{array}$ \\
\hline & 농진청 & $\begin{array}{l}\text { 한-아프리카 농식품 기술협력 협의체(KAFACI) 운영 } \\
\text { (개발컨설 팅, " } 11 \text { 년-계속, } 48.54 \text { 억, 계속) }\end{array}$ & 아프리카 & & $\begin{array}{l}\text { ㅇ 농진청의 사업은 아프리카에 적합한 쌀 } \\
\text { 품종을 개발하고 전파하는 것인 바, 동 } \\
\text { 사업으로 개발된 벼 품종을 농식품부 연구 } \\
\text { 단지 조성 사업에 활용토록 연계 }\end{array}$ \\
\hline \multirow{3}{*}{2} & 행자부 & $\begin{array}{l}\text { 미얀마 바간 사진 아카이브 보존 및 디지털화 사업 } \\
\text { (프로젝트, '18년-'19년, 3억/6억, 신규) }\end{array}$ & \multirow{3}{*}{ 미얀마 } & \multirow{3}{*}{ 연계 추진 } & \multirow{3}{*}{$\begin{array}{c}\circ \text { 행자부(국가기록원)의 사업으로 미얀마 } \\
\text { 바간 유적·벽화 관련 사진기록물을 디지 } \\
\text { 털화하는 작업 지원 } \\
\text { ○ 문화재청은 행자부의 디지털화 사업 결과를 } \\
\text { 활용하여 유적 등 복원 사업을 수행하고 } \\
\text { 문체부는 미얀마 디지털 문화자원지도 } \\
\text { 개발 및 관광안내, 교육 등에 활용 }\end{array}$} \\
\hline & $\begin{array}{l}\text { 문화 } \\
\text { 재청 }\end{array}$ & $\begin{array}{l}\text { 협력국 세계유산 보존관리 지원사업 } \\
\text { (프로젝트, '15년-'20년, 5억/18억, 계속) }\end{array}$ & & & \\
\hline & 문체부 & $\begin{array}{l}\text { 미얀마 문화예술 활용 역량 강화 지원 사업 } \\
\text { (프로젝트, '18년-'19년, } 10 \text { 억/20억, 신규) }\end{array}$ & & & \\
\hline \multirow[b]{2}{*}{3} & 문체부 & $\begin{array}{l}\text { 문화예술교육 } \mathrm{ODA} \text { (베트남) } \\
\text { (기타기술협력, '18년-'21년, 2억/8억, 신규) }\end{array}$ & \multirow[b]{2}{*}{ 베트남 } & \multirow[b]{2}{*}{ 연계 추진 } & \multirow{2}{*}{$\begin{array}{l}\text { ○ 문체부 사업으로 개발된 문화예술교육 } \\
\text { 프로그램을 KOICA 사업으로 건립될 소수 } \\
\text { 민족을 위한 중고등학교 기숙사에서의 } \\
\text { 방과후 활동에 활용 }\end{array}$} \\
\hline & KOICA & $\begin{array}{l}\text { 베트남 라오까이성 행복프로그램 } \\
\text { (프로젝트, '14년-'18년, 55억/156.8억, 계속) }\end{array}$ & & & \\
\hline \multirow[b]{2}{*}{4} & 교육부 & $\begin{array}{l}\text { BEAR 1 지속성 강화 사업 } \\
\text { (기타기술협력, "16년-'20년, } 0.6 \text { 억/3억, 계속) }\end{array}$ & 나미비아 & \multirow[b]{2}{*}{ 연계 추진 } & \multirow{2}{*}{ 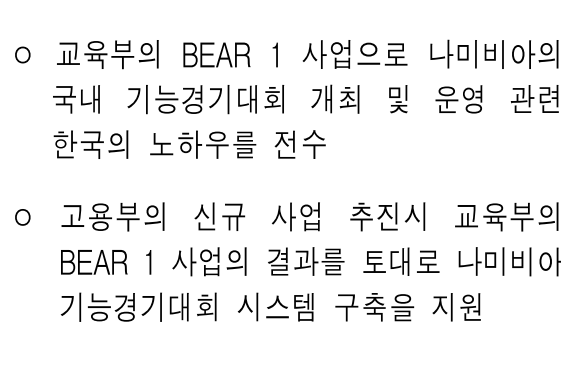 } \\
\hline & 고용부 & $\begin{array}{l}\text { 개도국 직업훈련분야 역량강화(기능경기) } \\
\text { (연수사업, '18년-'20년, 10억/30억, 신규) }\end{array}$ & $\begin{array}{l}\text { 잠비아 } \\
\text { 코스타리카 } \\
\text { 콜롬비아 } \\
\text { 나미비아 } \\
\quad \text { 몽골 }\end{array}$ & & \\
\hline \multirow[b]{2}{*}{5} & KOICA & $\begin{array}{l}\text { 미얀마 내수면 수산양식산업 기반조성지원 } \\
\text { (프로젝트, '14년-'18년, 49억/-, 계속) }\end{array}$ & \multirow{2}{*}{ 미얀마 } & \multirow[b]{2}{*}{ 연계 추진 } & \multirow{2}{*}{ 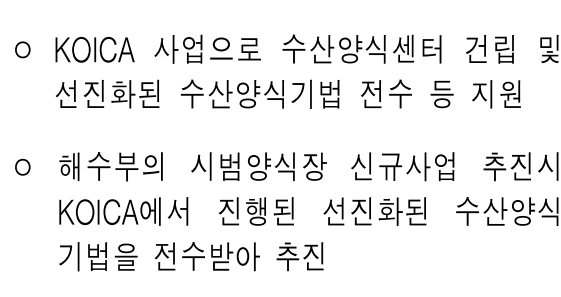 } \\
\hline & 해수부 & $\begin{array}{l}\text { 한국형 해상가두리 시범양식장 지원사업 } \\
\text { (프로젝트, '18년-'19년, 5.5억/11억, 신규) }\end{array}$ & & & \\
\hline \multirow[b]{2}{*}{6} & KOICA & $\begin{array}{l}\text { 니카라과 중등교사 ICT 교육역량강화사업 } \\
\text { (프로젝트, '17년-'20년, 4.6억/34.5억, 계속) }\end{array}$ & \multirow[b]{2}{*}{ 니카라과 } & \multirow[b]{2}{*}{ 연계 추진 } & \multirow{2}{*}{$\begin{array}{l}\text { O KOICA사업으로 카라소 ICT 연수센터에 } \\
\text { ICT 기자재 지원 } \\
\text { ○ 교육부 사업으로 니카라과 교원에 대힌 } \\
\text { 현지연수시 KOICA가 기자재를 지원힌 } \\
\text { 연수센터를 활용 }\end{array}$} \\
\hline & 교육부 & $\begin{array}{l}\text { 교류협력국 교육정보화 지원 } \\
\text { - 선도교원 초청연수 및 인프라 지원 } \\
\text { (연수사업, '18년, 0.79억, 신규) }\end{array}$ & & & \\
\hline
\end{tabular}




\begin{tabular}{|c|c|c|c|c|c|}
\hline & 기관 & 사 업 명 & 수 원 국 & 조정결과 & 내 용 \\
\hline \multirow[b]{2}{*}{7} & KOICA & $\begin{array}{l}\text { 케냐 초등학교 환경개선 및 역량강화사업 } \\
\text { (프로젝트, '14년-'19년, 4.53억/47.65억, 계속) }\end{array}$ & \multirow[b]{2}{*}{ 케냐 } & \multirow[b]{2}{*}{ 연계 추진 } & \multirow{2}{*}{ 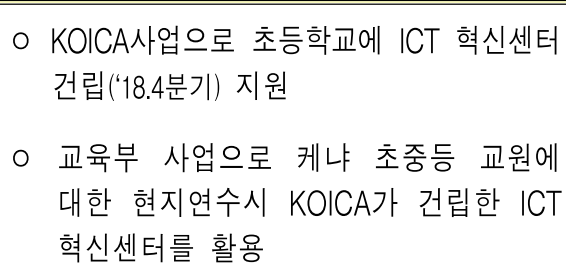 } \\
\hline & 교육부 & $\begin{array}{l}\text { 교류협력국 교육정보화 지원 } \\
\text { - 선도교원 초청연수 및 인프라 지원 } \\
\text { (연수사업, '18년, 0.79억, 신규) }\end{array}$ & & & \\
\hline \multirow{4}{*}{8} & 교육부 & $\begin{array}{l}\text { 첨단 ICT 활용 시범교실 구축운영지원 } \\
\text { (프로젝트, "18년-'22년, } 6.85 \text { 억/9,2억, 신규) }\end{array}$ & \multirow{4}{*}{ 르완다 } & \multirow{4}{*}{ 연계 추진 } & \multirow{4}{*}{ 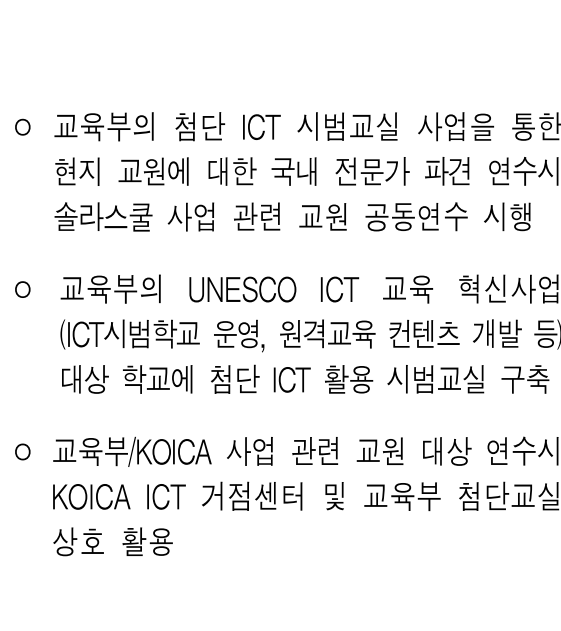 } \\
\hline & 교육부 & $\begin{array}{l}\text { 솔라스쿨 활용 교육 지원 } \\
\text { (프로젝트, "16년-'20년, } 0.48 \text { 억/1.66억, 계속) }\end{array}$ & & & \\
\hline & 교육부 & $\begin{array}{l}\text { UNESCO 아프리카 ICT 활용 교육혁신 지원 } \\
\text { (프로젝트, '15년-'18년, 9.66억/69억, 계속) }\end{array}$ & & & \\
\hline & KOICA & $\begin{array}{l}\text { 르완다 교사 및 예비교사 ICT 교육역량강화사업 } \\
\text { (프로젝트, '17년-'20년, 30억/80억, 계속) }\end{array}$ & & & \\
\hline \multirow{2}{*}{9} & 교육부 & $\begin{array}{l}\text { 첨단 ICT 활용 시범교실 구축 운영지원 } \\
\text { (프로젝트, '17년-'21년, } 1.48 \text { 억/8.33억, 계속) }\end{array}$ & \multirow{2}{*}{ 케냐 } & \multirow{2}{*}{ 연계 추진 } & \multirow{2}{*}{$\begin{array}{l}\text { ○ 교육부의 첨단 ICT 시범교실 사업을 통한 } \\
\text { 현지 교원에 대한 국내 전문가 파견 연수시 } \\
\text { 솔라스쿨 사업 관련 교원 공동연수 시행 }\end{array}$} \\
\hline & 교육부 & $\begin{array}{l}\text { 솔라스쿨 활용 교육 지원 } \\
\text { (프로젝트, '13년-'18년, 0.68억/3.39억, 계속) }\end{array}$ & & & \\
\hline \multirow{2}{*}{10} & 행자부 & $\begin{array}{l}\text { 라오스 새마을운동 시범마을 조성 및 관리 } \\
\text { (프로젝트, '15년-'19년, 1.74억/11.02억, 계속) }\end{array}$ & \multirow{2}{*}{ 라오스 } & \multirow{2}{*}{ 연계 추진 } & \multirow{2}{*}{$\begin{array}{l}\circ \mathrm{KOICA} \text { 농촌개발사업으로 건립될 연수원을 } \\
\text { 활용하여 행자부 사업 대상 마을 주민에 } \\
\text { 대한 연수(사후관리) 실시 }\end{array}$} \\
\hline & KOICA & $\begin{array}{l}\text { 라오스 농촌공동체 개발사업 } \\
\text { (프로젝트, "14년-'20년, 30억/162.96억, 계속) }\end{array}$ & & & \\
\hline \multirow{2}{*}{11} & 행자부 & $\begin{array}{l}\text { 캄보디아 새마을운동 시범마을 조성 및 관리 } \\
\text { (프로젝트, '15년-'19년, 0.3억/1.9억, 계속) }\end{array}$ & \multirow{2}{*}{ 캄보디아 } & \multirow{2}{*}{ 연계 추진 } & \multirow{2}{*}{$\begin{array}{l}\circ \mathrm{KOICA} \text { 농촌개발사업으로 건립될 연수원을 } \\
\text { 활용하여 행자부 사업 대상 마을 주민에 } \\
\text { 대한 연수(사후관리) 실시 }\end{array}$} \\
\hline & KOICA & $\begin{array}{l}\text { 캄보디아 농촌공동체 개발사업 } \\
\text { (프로젝트, '14년-'18년, 15억/100.43억, 계속) }\end{array}$ & & & \\
\hline \multirow{2}{*}{12} & 복지부 & $\begin{array}{l}\text { 캄보디아 통합모자보건 증진사업 } \\
\text { (프로젝트, '17년-'21년, 23억/129억, 계속) }\end{array}$ & \multirow{2}{*}{ 캄보디아 } & \multirow{2}{*}{ 연계추진 } & \multirow{2}{*}{$\begin{array}{l}\text { 으복지부 사업으로 건립된 조산사양성센터를 } \\
\text { 통해 기 건립된 } \mathrm{KOICA} \text { 모자보건센터의 } \\
\text { 병원운영 자문을 위한 전문가 파견, 의료 } \\
\text { 인력 연수 등 실시 }\end{array}$} \\
\hline & KOICA & $\begin{array}{l}\text { 캄보디아 씨엠립 주립병원 역량강화사업 } \\
\text { (프로젝트, '10년-'12년, 35억, 완료) }\end{array}$ & & & \\
\hline \multirow{2}{*}{13} & 행자부 & $\begin{array}{l}\text { 우간다 새마을운동 시범마을 조성 및 관리 } \\
\text { (프로젝트, '15년-'19년, 2.53억/14.27억, 계속) }\end{array}$ & \multirow{2}{*}{ 우간다 } & \multirow{2}{*}{ 연계 추진 } & \multirow{2}{*}{$\begin{array}{l}\circ \mathrm{KOICA} \text { 농촌개발사업으로 건립된 연수원을 } \\
\text { 활용하여 행자부 사업 대상 마을 주민에 대한 } \\
\text { 연수(사후관리) 실시 }\end{array}$} \\
\hline & KOICA & $\begin{array}{l}\text { 우간다 농촌개발 시범마을 건립사업 } \\
\text { (프로젝트, '15년-'18년, 8.11억/25.75억, 계속) }\end{array}$ & & & \\
\hline
\end{tabular}




\section{3. 중복방지 : 10 건 [21개 사업]}

\begin{tabular}{|c|c|c|c|c|c|}
\hline & 기관 & 사 업 명 & 수 원 국 & 조정결과 & 내 용 \\
\hline \multirow{2}{*}{1} & 경사연 & $\begin{array}{l}\text { 국제기술혁신협력사업(우간다) } \\
\text { (개발컨설 팅, '18년-'19년, 2억/4억, 신규) }\end{array}$ & \multirow{2}{*}{ 우간다 } & \multirow{2}{*}{$\begin{array}{l}\text { 통합 } \\
\text { (2개사업 } \rightarrow \\
\text { 1개사업) }\end{array}$} & \multirow{2}{*}{$\begin{array}{l}\text { 을사사사업 통폐합 } \\
\text { - 국제기술혁신협력사업(개발컨설팅)에 } \\
\text { 연수사업을 통합 }\end{array}$} \\
\hline & 경사연 & $\begin{array}{l}\text { 국제기술혁신ㅎㅕㅕ력사업(우간다) } \\
\text { (연수사업, } 18 \text { 년, 1억, 신규) }\end{array}$ & & & \\
\hline \multirow{2}{*}{2} & $\begin{array}{l}\text { 농식 } \\
\text { 품부 }\end{array}$ & $\begin{array}{l}\text { 개도국 식물검역전문가 초청연수사업 } \\
\text { (연수사업, "18년, } 1.15 \text { 억, 신규) }\end{array}$ & \multirow{2}{*}{$\begin{array}{l}\text { 아세안 } \\
\text { 개도국 }\end{array}$} & \multirow{2}{*}{$\begin{array}{l}\text { 통합 } \\
\text { (2개사업 } \rightarrow \\
\text { 1개사업) }\end{array}$} & \multirow{2}{*}{$\begin{array}{l}\text { 으유사사업 통폐합 } \\
\text { - 개도국 식물검역전문가 역량강화 } \\
\text { 사업으로 초청연수 및 워크숍 개초 } \\
\quad \text { 사업을 통합 }\end{array}$} \\
\hline & $\begin{array}{l}\text { 농식 } \\
\text { 품부 }\end{array}$ & $\begin{array}{l}\text { 식물검역 국제기준 아시아지역 워크숍 개최 } \\
\text { (기타기술협력, "18년, } 0.75 \text { 억, 신규) }\end{array}$ & & & \\
\hline \multirow{2}{*}{3} & 해수부 & $\begin{array}{l}\text { 키리바시 해수이용 수경재배 시스템 보급 및 운영 사업 } \\
\text { (프로젝트, '18년-20년, 3억7억, 신규) }\end{array}$ & \multirow{2}{*}{ 키리바시 } & \multirow{2}{*}{$\begin{array}{l}\text { 통합 } \\
\text { (2개사업 } \rightarrow \\
\quad \text { 1개사업) }\end{array}$} & \multirow{2}{*}{$\begin{array}{l}\text { 유유사사업 통폐합 } \\
\text { - 해수를 이용한 식수 및 식량생산 } \\
\text { 시스템 지원사업으로 2개 사업을 } \\
\text { 통합 }\end{array}$} \\
\hline & 해수부 & $\begin{array}{l}\text { 신재생 해수담수화 기술을 적용한 키리바시 식수지원 } \\
\text { (프로젝트, "18년-'21년, 1억/5억, 신규) }\end{array}$ & & & \\
\hline \multirow{3}{*}{4} & 해수부 & $\begin{array}{l}\text { 베트남 연 안지역 통합해양 환경관리 기반구축 } \\
\text { (프로젝트, '18년-'20년, 5억/15억, 신규) }\end{array}$ & \multirow{3}{*}{ 베트남 } & \multirow{3}{*}{$\begin{array}{l}\text { 통합 } \\
\text { (2개사업 } \rightarrow \\
\text { 1개사업) }\end{array}$} & \multirow{3}{*}{$\begin{array}{l}\text { O KOICA 사업으로 통폐합 } \\
\text { - 해수부·안전처 사업을 KOICA } \\
\text { 베트남 연안관리 및 해양 오염 } \\
\text { 대응 이행전략 수립 사업으로 통흥 }\end{array}$} \\
\hline & 안전처 & $\begin{array}{l}\text { 대규모 해양오염 대비를 위한 국가방제체계 } \\
\text { 구축 지원 사업 } \\
\text { (프로젝트, "18년-'20년, 15.12억/46.5억, 신규) }\end{array}$ & & & \\
\hline & KOICA & $\begin{array}{l}\text { 베트남 연안관리 및 해양 오염 대응 이행전략 수립 } \\
\text { (프로젝트, '18년-'20년, 2억/34.5억, 신규) }\end{array}$ & & & \\
\hline \multirow{2}{*}{5} & 관세청 & $\begin{array}{l}\text { 싱글윈도우 시스템 구축 지원(탄자니아) } \\
\text { (프로젝트, "18년-'20년, 20.7억/69억, 신규) }\end{array}$ & \multirow{2}{*}{ 탄자니 아 } & \multirow{2}{*}{$\begin{array}{c}\text { 통 합 } \\
\text { (2개사업 } \rightarrow \\
\text { 1개사업) }\end{array}$} & \multirow{2}{*}{$\begin{array}{l}\text { O KOICA 사업으로 통폐합 } \\
\text { - 관세청 사업을 KOICA 탄자니아 } \\
\text { 싱글윈도우 시스템 구축지원 } \\
\text { 사업으로 통합 }\end{array}$} \\
\hline & KOICA & $\begin{array}{l}\text { 탄자니아 싱글윈도우 시스템 구축 지원 사업 } \\
\text { (프로젝트, '18년-'20년, 2억/69억, 신규) }\end{array}$ & & & \\
\hline \multirow{2}{*}{6} & 농진청 & $\begin{array}{l}\text { 베트남 해외농업기술개발(KOPIA) 2차 사업 } \\
\text { (개발컨설팅, "14년-'18년, 10억/40억, 계속) }\end{array}$ & \multirow{2}{*}{ 베트남 } & \multirow{2}{*}{$\begin{array}{l}\text { 통합 } \\
\text { (2개사업 } \rightarrow \\
\quad \text { 1개사업) }\end{array}$} & \multirow{2}{*}{$\begin{array}{l}\text { O 유사사업 통폐합 } \\
\text { - 베트남 해외농업기술 개발(KOPIA) } \\
\text { 2차 사업에 땅콩 재배 시범마을 } \\
\text { 사업을 통합 }\end{array}$} \\
\hline & 농진청 & $\begin{array}{l}\text { 베트남 땅콩 KOIPIA 시범마을 조성 사업 } \\
\text { (프로젝트, '17년-'19년, 5억/15억, 계속) }\end{array}$ & & & \\
\hline \multirow[t]{2}{*}{7} & 농진청 & $\begin{array}{l}\text { 케냐 해외농업기술개발(KOPIA) 2차 사업 } \\
\text { (개발컨설팅, '14년-'18년, 10억/35억, 계속) }\end{array}$ & \multirow{2}{*}{ 케냐 } & \multirow{2}{*}{$\begin{array}{l}\text { 통합 } \\
\text { (2개사업 } \rightarrow \\
\text { 1개사업) }\end{array}$} & \multirow{2}{*}{$\begin{array}{l}\text { 유유사사업 통폐합 } \\
\text { - 케냐 해외농업기술개발(KOPIA) } \\
\text { 2차 사업에 양계·감자 재배 } \\
\text { 시범마을 사업을 통합 }\end{array}$} \\
\hline & 농진청 & $\begin{array}{l}\text { 케냐 양계·감자 KOPIA 시범마을 조성 사업 } \\
\text { (프로젝트, '16년-'18년, 5억/15억, 계속) }\end{array}$ & & & \\
\hline \multirow{2}{*}{8} & 농진청 & $\begin{array}{l}\text { 에티오피아 해외농업기술개발(KOPIA) 2차 사업 } \\
\text { (개발컨설팅, "16년-'20년, 6억/20억, 계속) }\end{array}$ & \multirow{2}{*}{ 에티오피아 } & \multirow{2}{*}{$\begin{array}{l}\text { 통 합 } \\
\text { (2개사업 } \rightarrow \\
\text { 1개사업) }\end{array}$} & \multirow{2}{*}{$\begin{array}{l}\text { O 유사사업 통폐합 } \\
\text { - 에티오피아 해외농업기술개발(KOPIA } \\
\text { 2차 사업에 마늘 재배 시범마을 } \\
\text { 사업을 통합 }\end{array}$} \\
\hline & 농진청 & $\begin{array}{l}\text { 에티오피아 마늘 KOPIA 시범마을 조성 사업 } \\
\text { (프로젝트, '18년-'20년, 5억/15억, 신규) }\end{array}$ & & & \\
\hline
\end{tabular}




\begin{tabular}{|c|c|c|c|c|c|}
\hline & 기관 & 사 업 명 & 수 원 국 & 조정결과 & 내 용 \\
\hline \multirow[t]{2}{*}{9} & 농진청 & $\begin{array}{l}\text { 파라과이 해외농업기술개발(KOPIA) 2차 사업 } \\
\text { (개발컨설팅, '15년-'19년, 10억/25.5억, 계속) }\end{array}$ & \multirow[t]{2}{*}{ 파라과이 } & \multirow{2}{*}{$\begin{array}{c}\text { 통합 } \\
\text { (2개사업 } \rightarrow \\
\text { 1개사업) }\end{array}$} & \multirow{2}{*}{$\begin{array}{l}0 \text { 유사사업 통폐합 } \\
\text { - 파라과이 해외농업기술개발(KOPIA) } \\
\text { 2차 사업에 참깨 재배 시범마을 } \\
\text { 사업을 통합 }\end{array}$} \\
\hline & 농진청 & $\begin{array}{l}\text { 파라과이 참깨 KOPIA 시범마을 조성 사업 } \\
\text { (프로젝트, '16년-'18년, 5억/15억, 계속) }\end{array}$ & & & \\
\hline \multirow[t]{2}{*}{10} & 농진청 & $\begin{array}{l}\text { 세네갈 해외농업기술개발(KOPIA) 2차 사업 } \\
\text { (개발컨설팅, '17년-'22년, 6억/28억, 계속) }\end{array}$ & \multirow{2}{*}{ 세네갈 } & \multirow{2}{*}{$\begin{array}{c}\text { 통합 } \\
\text { (2개사업 } \rightarrow \\
\text { 1개사업) }\end{array}$} & \multirow{2}{*}{$\begin{array}{l}0 \text { 유사사업 통폐합 } \\
\text { - 세네갈 해외농업기술개발(KOPIA) } \\
\text { 2차 사업에 땅콩 재배 시범마을 } \\
\text { 사업을 통합 }\end{array}$} \\
\hline & 농진청 & $\begin{array}{l}\text { 세네갈 땅콩 KOPIA 시범마을 조성 사업 } \\
\text { (프로젝트, '18년-'20년, 5억/15억, 계속) }\end{array}$ & & & \\
\hline
\end{tabular}




\section{2 투명한 ODA}

\section{ODA 사업 소 과정의 투명성 제교}

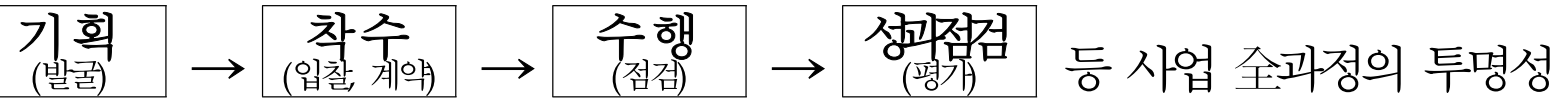
제고로 부적절한 개입 여지 차단(외부전문가 참여, 결과 공개 등)

* 유상 차관사업의 경우는 수원국 정부와 공개 여부 및 범위 등을 협의·추진

(1)「기획」단계 $\rightarrow$ 부적절한 개입 차단

i ) 사전 타당성 조사 등 기본요건 심사 대폭 강화

아사전타당성 조사 결과, 수원국 수원총괄기관의 요청서 등이 예외없이 구비되도록 심사

* 프로젝트·프로그램·개발컨설팅 등 사전타당성 조사 등이 의무화된 유형

에에난된 사업에 대해 현지의 재외공관 의견을 수렴하여 현지상황에 적합하게 추진되도록 유도

ii ) 사전타당성 조사에 민간전문가 참여(사업규모 고려 단계적 추진), 결과 공개

* 사전타당성 조사가 필수적인 프로젝트, 프로그램, 개발컨설팅에 적용

- 유상사업 사전 $\mathrm{F} / \mathrm{S}$ (pre-Feasibility Study) 기능 대폭 강화(외부 전문기관 등 실시로 객관성 담보)

iii) 사업 기획-발굴 단계부터 민간전문가가 참여하는 사업 심의위원회 개최 검토.추진

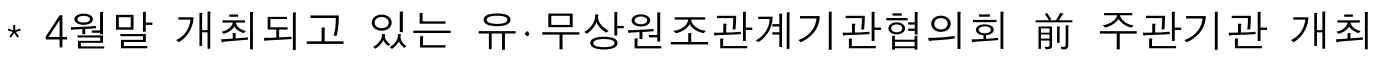


(2)「착수」 단계 $\rightarrow$ 정보공개 등 투명성 제고

애배별 사업의 시행기관 뿐 아니라 협약에 의해 실제 사업을 위탁받아 수행하는 기관(업체, 대학 등) 리스트 까지 공개 추진

(3)「수행」단계 $\rightarrow$ 현지 이행점검 강화

i ) 시행기관의 자체 사업 모니터링 활성화 및 주관기관 ${ }^{*}$ 의 이행점검 강화 * 주관기관은 이행점검 필요한 대상사업 선정기준 마련 및 시행기관과 공유 - 재외공관은 소재지 사업에 대한 상시 모니터링 및 결과 보고 체계 구축(최소 연 2회)

ii) 현지 이행점검에는 시행기관 뿐 아니라 민간전문가 참여 강화, 점검결과의 객관성 담보

iii) 점검결과의 차년도 사업심사시 반영 제도화

* 주관기관은 기준이하 사업 및 차년도 사업심사시 반영 기준 마련, 시행기관과 공유

(4)「평가」단계 $\rightarrow$ 민간전문가 참여 등 객관성 제고

i ) 시행기관의 자체평가에 민간전문가 참여 활성화

* 외부 전문기관 용역을 통한 평가 지속 확대 유도 및 최소 평가 작업에 민간전문가 참여 의무화

ii) 시행기관의 사업별 자체평가결과 보고서도 공개

(5) 모든 기관에 적용될 유무상 분야별 표준 사업심의절차 마련 - 시행

이사업발굴 및 사전타당성 조사 $(n-2) \rightarrow$ 사업심의위원회 개최(n-1) $\rightarrow$ 주관기관의 기관간협의회 개최(n-1) 등 절차를 표준화, 소기관 적용

$\Rightarrow$ 사업심의시(주관기관, 국개위) 사전타당성 조사 등에 민간전문가 참여, 결과 공개 여부 등 엄격 심사 


\section{2 수요자 친화적 정보 공개 확대}

\section{$\square$ 대국민 정보 공개 확대}

O ODA 통계시스템(stats.odakorea.go.kr에 구축)에서 공개하는 정보의 범위를 확대하고 수요자 친화적으로 재설계(시스템 정비 완료 후 7월부터 본격 활용)

i ) 지원국가 및 지원금액을 시각화하여 제공 (신설)

* 수원국별 규모 매핑(세계지도상에 표기)

ii) 총괄 조회기능 활성화

* (현행) 유형별(양 - 다자, 유-무상) 총액만 공개 $\Rightarrow$ (개선) 연도별 추이, 수원국·지역·분야·소득수준별 비교 기능 추가

iii) 사업 정보 공개범위 확대

* (현행) 사업명, 금액만 공개 $\Rightarrow$ (개선) 주요 사업내용, 세부사업 리스트, 지원조건, 실제 사업수행기관 등 추가

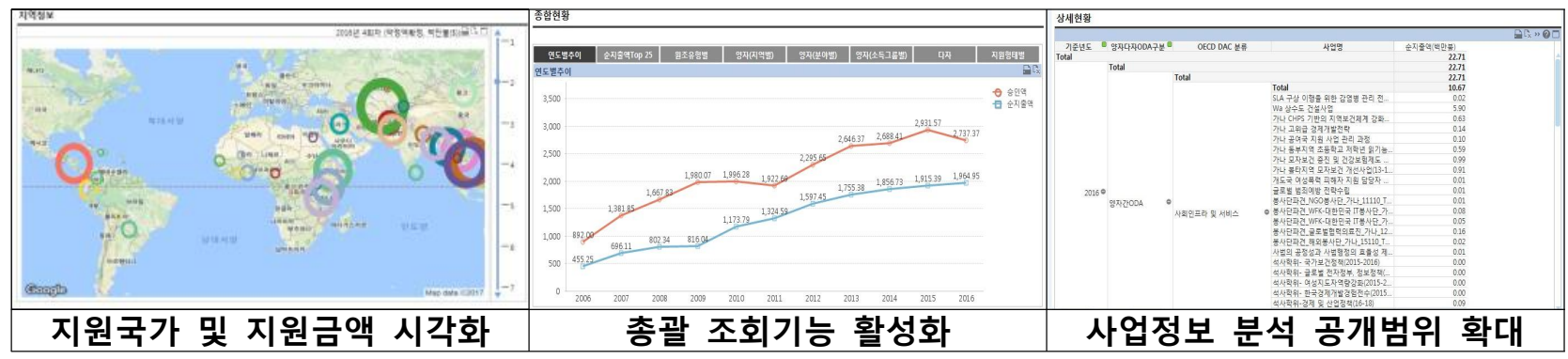

\section{국제기준에 부합하는 사업정보 공개 확대}

O 국제원조투명성기구(IATI) 필수공개 항목(13개) 포함 총 18 개 항목 공개, $\mathrm{EDCF}$-코이카외 부처(기재부·외교부·복지부) 사업정보도 공개

ㅇㅎㅇㅎㅜ, 관계기관 협의를 통해 공개하는 사업정보 항목 및 정보 공개 참여기관 범위를 지속적으로 확대

* 공개항목을 20 개 이상으로 확대하는 방안을 추진하고, 모든 중앙부처 및 산하기관의 정보공개 참여 검토 


\section{3 범국민 이해와 참여 증진}

\section{$\square$ 개 요}

ㅇ 국제개발협력은 '지구촌 가족의 구성원'으로서 '개발도상국의 지속가능한 개발과 성장'을 위해 지원이 필요하다는 대국민 인식 개선을 목표로 홍보 등 추진

으대국민 홍보 및 정보제공 확대 등 일반 국민과의 접점 확대, 청년층 참여 기회 확대 등 차세대 지지층 확보

\section{$\square$ 주요 추진 계획}

일반 국민과의 접점 확대

- (온라인) 고객 중심의 다양한 홍보채널 및 콘텐츠로 ODA에 대한 관심 제고

* 홈페이지, SNS 등을 통해 동영상, 생방송, 카드뉴스, 이벤트 등으로 흥미 유도

- (오프라인) 대중교통시설 홍보영상 방영 ${ }^{*}, \mathrm{ODA}$ 전시관 및 박람회 운영**, 간담회 개최 등을 통해 대국민 인식 개선 추진

* 지하철, $\mathrm{KTX} / \mathrm{SRT}$, 버스 등에 홍보영상 방영

** $\mathrm{EDCF}$ 사료전시관 상설 운영('17년 시범운영), $\mathrm{KOICA}$ 지구촌체험관을 통한 전시 및 체험학습 프로그램 운영, 지방도시 ODA 박람회 개최 등

ㅇㅊ청년층 참여 기회 확대로 차세대 지지층 확보

- 개발협력 교육 기회 확대 ${ }^{*}$ 및 $\mathrm{ODA}$ 관심 청년층 대상 참여 프로그램 ${ }^{* *}$ 운영 내실화

* KOICA ODA 교육원, EDCF 개발협력아카데미 등을 통한 교육 내실화

** WFK 봉사단, 청년인턴(KOICA, EDCF), 캠프, 경시대회 등을 통해 참여 기회 부여 확대

- 대학생 서포터즈를 통해 또래집단 대상 홍보활동 강화

우주요 계기 활용 대국민 홍보 확대

- 개발원조의 날(11.25), 개발협력주간(11.20 11.25) 등 개발협력 관련 행사 계기 집중적인 홍보 실시 


\section{3 함께하는 ODA}

\section{$10 \mathrm{OA}$ 생태계 육성을 통한 일자리 기여 및 민간과 파트너십 강화}

\section{1-1 ODA 생태계 육성 등을 통한 일자리 기여}

\section{$\square$ 개 요}

이발협력분야 청년기업 등 진출기반 지원, 인재양성 프로그램 확대 등을 통해 전문가 배양 생태계 조성 및 일자리와 연계

\section{$\square$ 주요 사업}

잉쳔기술기업, 기술스타트업 기업 등의 국제원조 진출 기반 확대 - 특히, 개도국에 유용한 혁신기술 보유한 청년기업 등 적극 발굴 <대표 사업>

- 혁신적 기술 프로그램 (CTS : Creative Technology Solution)

- 과학기술과 혁신적 접근을 기반으로 개도국 사회문제 해결에 필요한 기술개발 및 사업화를 지원 $\rightarrow$ 청년기술기업, 기술스타트업 기업 등의 $\mathrm{ODA}$ 참여 및 국제원조 무대 진출 기반 마련

- ‘18년 규모 : 94.8억원

*'15년 34억원 $\rightarrow$ '16년 22.0억원 $\rightarrow$ '17년 72.5억원 $\rightarrow$ '18년 94.8억원

이청 장년층의 현지 사업 등 참여 확대로 글로벌 청년인재 및 지역 전문가 등 전문인력으로 양성, 양질의 일자리로의 진입가능성 확대 


\section{<대표 사업>}

- 해외봉사단(WFK : World Friends Korea)

- 국내 청 - 장년층의 현지 봉사활동 참여를 통해 현지 주민 삼 개선 도모 + 글로벌 청년인재 및 지역 전문가 양성 기여

- '18년 규모 : 1,276억원

* '15년 1,022억원 $\rightarrow$ '16년 1,021억원 $\rightarrow$ '17년 1,040억원 $\rightarrow$ '18년 1,276억원

- 해외봉사단 코디네이터

- WFK 해외봉사단의 안전 및 복무 관리 강화에 필요한 인력 확대

- '18년 규모 : 180억원

*'15년 133억원 $\rightarrow$ '16년 174억원 $\rightarrow$ '17년 165억원 $\rightarrow$ '18년 180억원

> 청년인턴 사업

- KOICA- EDCF 등 해외사무소 및 ODA 사업수행기관에 채용을 통해 현장 실무경험 지원

- '18년 규모 : (KOICA) 156억원" / (EDCF) 6.24억원(*'17년대비 2배 증가)

* '15년 90.9억원 $\rightarrow$ '16년 136.96억원 $\rightarrow$ '17년 107.11억원 $\rightarrow$ '18년 156억원

ㅇ 국제기구 진출을 희망하는 청년층 대상 참여기회를 확대하여 국제기구 진출을 위한 경력사다리 제공

\section{<대표 사업>}

- 국제금융기구 초급전문가(JPO: Junior Professional Officer) 파견 사업 / 국제기구 다자협력전문가 파견사업 $(\mathrm{KMCO}: \mathrm{KOICA}$ Multilateral Cooperation Officer)

- 국제기구 진출을 희망하는 청년전문가를 대상으로 국제기구 개발협력 활동 참여 기회를 제공 $\rightarrow$ 국제기구 전문가 양성 기여

- "18년 규모 : (국제기구 초급전문가 파견사업) 20.13억원" / (KMCO) 14.23억원 * 국제기구 초급전문가 파견사업의 경우 전년대비('17년 4.03억원) 5 배 증가

\section{$\square$ 향후 계획}

ㅇ 우리 전문인력 글로벌 진출 및 개도국의 경제·사회·문화 발전을 동시에 도모할 수 있는 프로그램 적극 발굴·확산

일요시 기존 사업의 효과성을 점검하여 사업과 실질적인 일자리 창출이 연계되도록 프로그램 정비 


\section{1-2 민간과의 파트너십 강화}

\section{개 요}

인관협력 사업 지속 확대, 민간부문과의 공동 투자 활성화, 시민사회 역량 강화 등을 통한 민간과의 파트너십 강화 추진

\section{$\square$ 주요 지원 분야 및 사업}

ㅇ (민관협력사업 ${ }^{*}$ 국내 시민단체, 기업, 대학 및 연구기관과의 협력 사업 지속 확대로 민간 창의성 - 노하우 활용 및 파트너십 강화

* 외교부, $\mathrm{KOICA}$, 개별부처가 시민단체, 기업, 대학 및 연구기관 대상으로 사업 공모후 사업비 일부(50 90\%)를 지원하는 형태로 추진중

- 관련 사업 규모 지속 확대 ('17년 664억원 $\rightarrow$ '18년 787억원, 약 19\% 증가)

○ $\left(\mathrm{PPP}^{*}\right.$ 방식 사업) 순수 민간투자가 어려운 개도국의 대형 인프라사업에 대해 PPP방식 투자진출 확대 모색

* 개도국 정부가 민자사업 추진시, 사업시행법인(SPC)에 대한 개도국 정부의 정부출자금을 EDCF가 차관으로 지원하는 방식(Public Private Partnership)

- '18년에는 라오스 세피안-세남노이 수력발전 사업 지속 추진

* 솔로몬 티나강 수력발전, 베트남 떤반-년짝도로 건설사업도 향후 추진 예정

ㅇ (개발금융) 대규모 재원이 소요되어 $\mathrm{EDCF}$ 단독지원이 어려운 사업을 대상으로 시장 차입자금을 활용하여 양허성 차관 지원 - 타당성조사 등을 통해 개발금융 적용 가능 사업 발굴 및 집행 노력

O (시민사회 역량 강화) 초/중/고 및 대학생 대상 맞춤형 글로벌 시민교육 및 국제개발협력의 이해 교육 실시

* KOICA ODA 교육원을 통한 글로벌시민 및 국제개발협력 전문가 육성 


\section{2 인도적 지원 단계적 확대}

$\square$ 개 요

ㅇ 글로벌 인도적 위기 심화*에 따라 중견 공여국인 우리나라에 대한 국제사회의 기대가 높아지고 있는 상황

* 2차 대전 이래 최악의 난민위기, 기후변화, 감염병 등으로 인도적 위기 장기화·복합화 추세

윽국사회의 요구에 대응하여 인도적 지원 규모 지속 확대 ('16년 461억원 $\rightarrow$ '17년 900억원 $\rightarrow$ '18년 1,572억원)

\section{지원 전략}

ㅇ '18년 1,572억원에 대해서 국가별, 대상별, 분야별 중점 지원 분야를 선정하여 지원 계획

- (국가별) 시리아, 이라크 등 주요 분쟁취약국 (대상별) 난민, 여성, 아동 등 취약계층 (분야별) 교육, 보건, 직업훈련

으 과정에서 UNHCR, UNICEF, OCHA 등 핵심 인도지원 기구들과의 연례 정책협의회를 개최, 기구별 전문성을 감안한 효과적 인도적 지원 실시

$\square$ 향후 추진계획

ㅇ 중장기적으로 인도적 지원 규모 지속 확대 추진

* 2015년 기준 OECD DAC 회원국의 ODA 대비 인도적 지원 비율은 평균 $12.7 \%$ 수준(한국은 $3.2 \%$ )

인도적 지원 예산의 효과성-가시성 차원에서 중점 분야 위주 지원 지속 


\section{3 글로벌 파트너십 강화}

개 요

O $\mathrm{OECD}$ 개발원조위원회 동료검토 활용, 주요 선진공여국 및 국제기구 등과의 협력 강화 등을 통해 ODA 사업 선진화 추진

\section{주요 추진 계획}

옹료검토 결과에 따른 $\mathrm{ODA}$ 체계·사업 등 내실화

- '17년 수검한 OECD DAC 동료검토(peer review) 결과(권고사항 이행 등) 활용방안을 마련, $\mathrm{ODA}$ 정책·집행 개선 추진

* $\mathrm{DAC}$ 측 권고사항을 존중하면서 우리 실정에 맞는 정책적 우선순위 및 필요성 등을 고려, 부처간 협의를 통해 추진과제를 선정하고 이행 추진

○ 국제기구와의 협력 강화

- 지역별 전문성을 가진 국제금융기구(MDB)와의 협력사업 발굴을 통해 $\mathrm{ODA}$ 사업의 현지적합성 강화

* 니카라과 지열발전탐사 및 송전망 확충지원 사업(IDB 협력), 방글라데시 ICT 교육훈련 센터 건립사업(ADB 협력) 등

- 접근성 부족 등 양자사업이 시행되기 어려운 지역에 대한 지 원은 국제기구와의 협력을 적극 활용·지원

* WFP 니제르 기후변화 위험관리 역량강화를 통한 식량안보 지원사업, $\mathrm{UNDP}$ 사모아 여성 정치활동 참여 지원 사업 등

- AfDB 연차총회 및 한-아프리카 장관급 경제협력회의 공동 개최('18.5월)를 통한 對아프리카 지원 전략 고도화

어선진 공여국과의 협력 강화

- 지속가능개발목표(SDGs) 이행 지원을 위한 선진공여국(미국 ·EU·일본·영국 등)의 경험 공유 및 원조정책·제도 선진화 


\section{V. '18년 국제개발협력 사업 개요}

\section{1 총 괄}

$\square$ (총규모) 요구액 규모는 약 3 조 1,895 억원이며, 총 43 개 기관 (지자체 11개 포함) 1,372 개 사업

아업ㅂㅂ규모는 ' 17 년 대비(2조 6,359억) 5,536 억원 증가

* 제2차 기본계획('16 '20)상 '20년 $\mathrm{ODA} / \mathrm{GNI}$ 비율 목표는 $0.20 \%$ 이며, '18년 목표치는 $0.17 \%(16$ 년 실적은 $0.14 \%)$

* '17년 실적은 '18년초 산정 예정

○ 참여기관은 ' 17 년 대비(42개) 1 개 증가

* 중앙행정기관 1 개 감소(중기청 추가, 보훈처·검찰청 제외), 지방자치단체 2개(광주·제주 추가) 증가

아어업 수는 '17년 대비(1,243개) 129개 증가

\begin{tabular}{c|r|r|r|r|r|r|r}
\hline 구분 & \multicolumn{1}{|c|}{2012} & \multicolumn{1}{c|}{2013} & \multicolumn{1}{c|}{2014} & \multicolumn{1}{c|}{2015} & \multicolumn{1}{c}{2016} & \multicolumn{1}{c}{2017} & \multicolumn{1}{c}{2018} \\
\hline \hline 총ODA(십억원) & $1,798.6$ & $1,921.4$ & $1,955.2$ & $2,166.9$ & $2,280.5$ & $2,635.9$ & $3,189.5$ \\
\hline 양자간원조 & $1,332.1$ & $1,433.4$ & $1,469.8$ & $1,732.1$ & $1,784.9$ & $2,130,0$ & $2,629.0$ \\
비중(\%) & $(74.1)$ & $(74.6)$ & $(75.2)$ & $(79.9)$ & $(78.3)$ & $(80.7)$ & $(82.4)$ \\
\hline 무상원조 & 804.9 & 885.5 & 930.5 & $1,096.0$ & 1131.9 & $1,175.5$ & $1,570.9$ \\
비중(\%) & $(60.4)$ & $(61.8)$ & $(63.3)$ & $(63.3)$ & $(63.4)$ & $(55.2)$ & $(59.8)$ \\
\hline 유상원조 & 527.3 & 547.9 & 539.3 & 636.1 & 652.7 & 954.5 & $1,058.1$ \\
비중(\%) & $(39.6)$ & $(38.2)$ & $(36.7)$ & $(36.7)$ & $(36.6)$ & $(44.8)$ & $(40.2)$ \\
\hline 다자간원조 & 466.4 & 487.9 & 485.4 & 434.8 & 495.8 & 505.9 & 560.5 \\
비중(\%) & $(25.9)$ & $(25.4)$ & $(24.8)$ & $(20.1)$ & $(21.7)$ & $(19.3)$ & $(17.6)$ \\
\hline
\end{tabular}

* '12 '16년은 실적('16년은 잠정) 수치이며, '17년은 예산, '18년은 요구액 수치

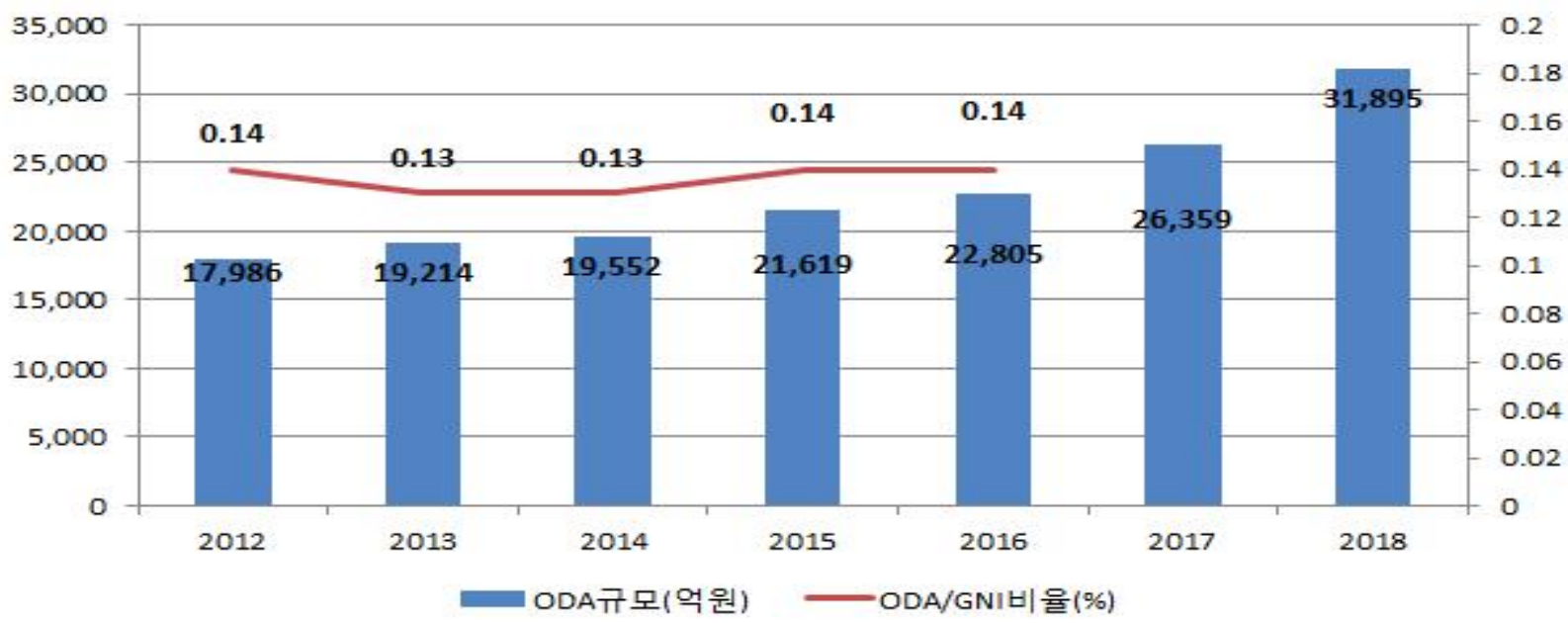


$\square$ (유형별) 총 ODA 중 양자협력 對 다자협력간 비율은 약 82:18, 유상협력 對 무상협력간 비율은 40:60 수준(요구액 기준)

ㅇ '17년 양-다자 비율(81:19)에 비해 양자협력 비율 증가

○ '17년 유·무상 비율(45:55)에 비해 무상협력 비율 증가

* 제2차 국제개발협력 기본계획('16 '20)상 양-다자 비율 목표(75:25)에 비해 양자협력의 비율이 다소 높음

$\square$ (지역별) 아시아 중심 기조 유지하되, '17년에 비해 중남미 $(5.0 \% \rightarrow 7.5 \%)$, 중동.CIS 비중 $(7.5 \% \rightarrow 11.2 \%)$ 증가

\begin{tabular}{c|c|c|c|c|c|c|c}
\hline 구 분 & 구분 & 아시아 & 아프리카 & 중남미 & 중동· CIS & 오세아니아 & 기타 \\
\hline \hline \multirow{3}{*}{ 규모(억원) } & 유상 & 5,192 & 2,366 & 886 & 2,136 & - & - \\
\cline { 2 - 8 } & 무상 & 4,038 & 2,483 & 1,096 & 798 & 185 & 7,108 \\
\cline { 2 - 8 } & 총계 & 9,230 & 4,849 & 1,982 & 2,934 & 185 & 7,108 \\
\hline \multirow{3}{*}{ 비중(\%) } & 유상 & 49.1 & 22.4 & 8.4 & 20.2 & - & - \\
\cline { 2 - 8 } & 무상 & 25.7 & 15.8 & 7.0 & 5.1 & 1.2 & 45.2 \\
\cline { 2 - 8 } & 총계 & 35.1 & 18.4 & 7.5 & 11.2 & 0.7 & 27.0 \\
\hline
\end{tabular}

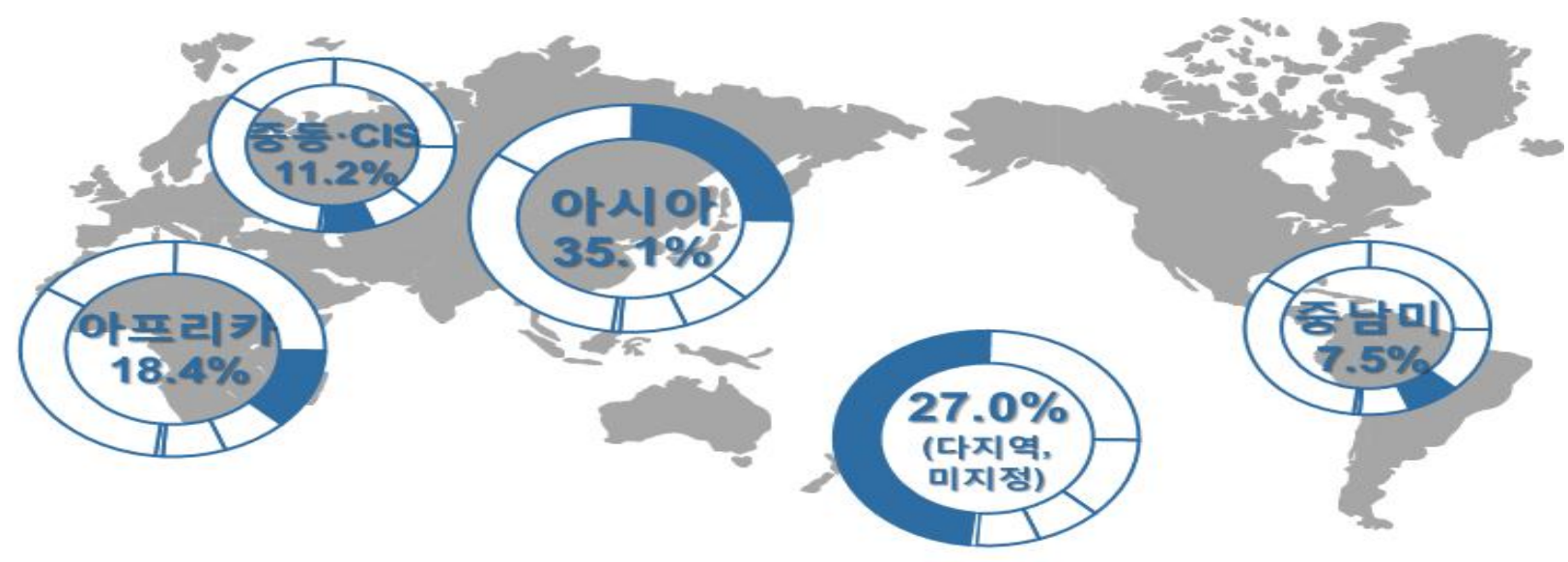

$\square$ (분야별) 교통, 보건, 공공행정, 교육 등을 중심으로 지원

\begin{tabular}{c|c|c|c|c|c|c|c|c|c|c}
\hline \multirow{2}{*}{ 구 분 } & 구분 & 교통 & 보건 & 공공행정 & 교육 & 농림수산 & $\begin{array}{c}\text { 산업 } \\
\text { 에 너지 }\end{array}$ & $\begin{array}{c}\text { 인도적 } \\
\text { 지원 }\end{array}$ & 환경 & 기타 \\
\hline \hline \multirow{3}{*}{ 규모(억원) } & 유상 & 3,737 & 1,355 & 1,079 & 674 & 392 & 727 & - & - & 2,617 \\
\cline { 2 - 12 } & 무상 & 109 & 1,633 & 1,570 & 1,849 & 1,628 & 847 & 1,572 & 422 & 6,078 \\
\cline { 2 - 12 } & 총계 & 3,846 & 2,988 & 2,649 & 2,523 & 2,020 & 1,574 & 1,572 & 422 & 8,695 \\
\hline \multirow{3}{*}{ 비중(\%) } & 유상 & 35.3 & 12.8 & 10.2 & 6.4 & 3.7 & 6.9 & - & - & 24.7 \\
\cline { 2 - 12 } & 무상 & 0.7 & 10.4 & 10.0 & 11.8 & 10.4 & 5.4 & 10.0 & 2.7 & 38.7 \\
\cline { 2 - 11 } & 총계 & 14.6 & 11.4 & 10.1 & 9.6 & 7.7 & 6.0 & 6.0 & 1.6 & 33.1 \\
\hline
\end{tabular}


$\square$ (형태별) 프로젝트 사업을 중심으로 다양한 형태로 지원

\begin{tabular}{|c|c|c|c|c|c|c|c|c|c|c|}
\hline 구 분 & 구분 & 프로젝트 & $\begin{array}{c}\text { 봉사단 } \\
\text { 파견 }\end{array}$ & $\begin{array}{c}\text { 연수사업 } \\
\text { (장학지원 } \\
\text { 포함) }\end{array}$ & $\begin{array}{l}\text { 개발 } \\
\text { 컨설팅 }\end{array}$ & 프로그램 & 민관협력 & $\begin{array}{c}\text { 기타 } \\
\text { 기술협력 }\end{array}$ & 행정비용 & 기타 \\
\hline \multirow{3}{*}{ 규모(억원) } & 유상 & 10,581 & - & - & - & - & - & - & - & ב- \\
\hline & 무상 & 6,442 & 1,630 & 1,455 & 1,127 & 1,104 & 787 & 279 & 267 & 2,617 \\
\hline & 총계 & 17,023 & 1,630 & 1,455 & 1,127 & 1,104 & 787 & 279 & 267 & 2,617 \\
\hline \multirow{3}{*}{ 비중(\%) } & 유상 & 100 & - & - & - & - & - & - & - & - \\
\hline & 무상 & 41.0 & 10.4 & 9.3 & 7.2 & 7.0 & 5.0 & 1.8 & 1.7 & 16.6 \\
\hline & 총계 & 64.8 & 6.2 & 5.5 & 4.3 & 4.2 & 3.0 & 1.1 & 1.0 & 9.9 \\
\hline
\end{tabular}

가. 분야별 비 중 (기타 제외)

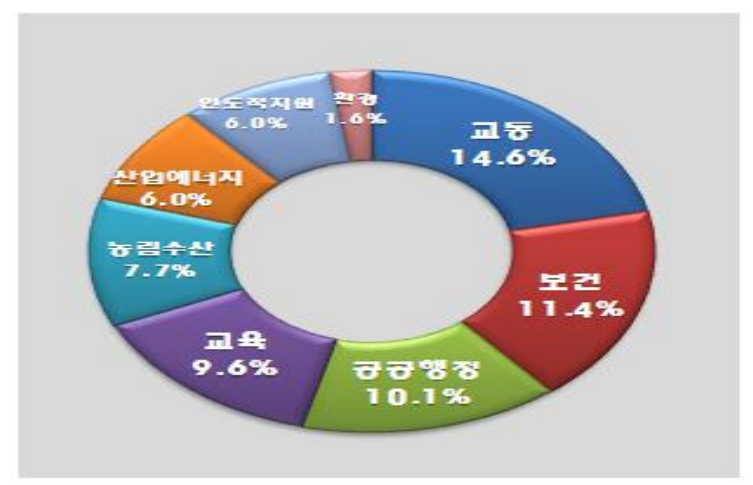

나. 유형별 비 중 (기타 제외)

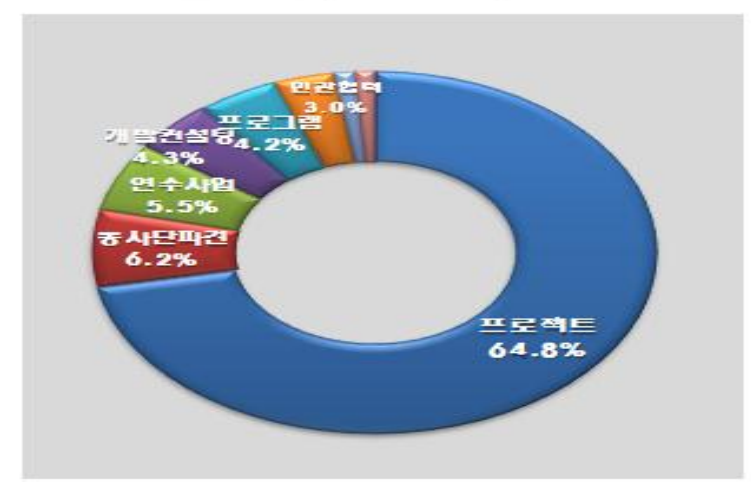

$\square$ (신규/예속) 신규사업 적극 발굴로 '17년에 비해 신규 사업의 규모 및 사업 수 증가

* 신규사업 규모 : ‘17년 대비(2,197억) 1,923억 증가

신규사업수 : ‘17년 대비(342개) 138개 증가

신규사업 비중 : "17년 대비 $(9.2 \%) 4.8 \%$ 증가

\begin{tabular}{c|c|c|c|c}
\hline 구 분 & 구분 & 신규 & 계속 & 합계 \\
\hline \hline \multirow{2}{*}{$\begin{array}{c}\text { 규모 } \\
\text { (억원) }\end{array}$} & 유상+MDB & 1,726 & 10,285 & 12,011 \\
\cline { 2 - 5 } & 무상+UN & 2,494 & 14,981 & 17,395 \\
\cline { 2 - 5 } & 총계 & 4,120 & 25,266 & 29,386 \\
\hline \multirow{2}{*}{$\begin{array}{c}\text { 비중 } \\
\text { (\%) }\end{array}$} & 유상+MDB & 14.4 & 85.6 & 100 \\
\cline { 2 - 5 } & 무상+UN & 13.8 & 86.2 & 100 \\
\cline { 2 - 5 } & 총계 & 14.0 & 86.0 & 100 \\
\hline
\end{tabular}

가. 규모

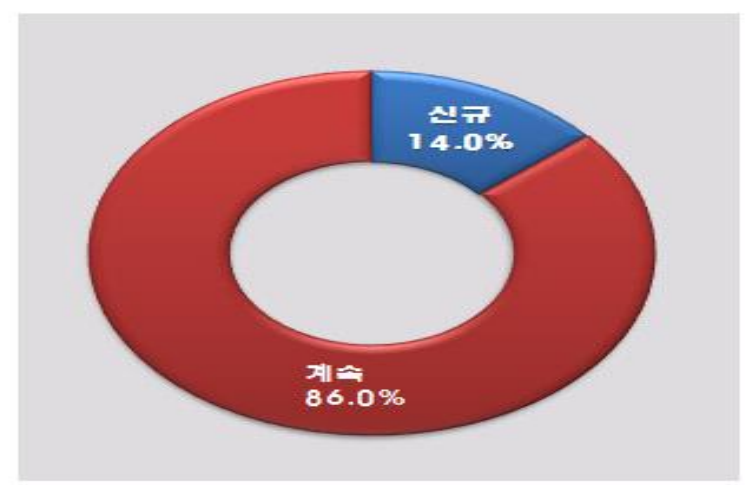

\begin{tabular}{c|c|c|c|c}
\hline 구 분 & 구분 & 신규 & 계속 & 합계 \\
\hline \hline \multirow{2}{*}{$\begin{array}{c}\text { 사법수 } \\
\text { (건) }\end{array}$} & 유상+MDB & 20 & 109 & 129 \\
\cline { 2 - 5 } & 무상+UN & 460 & 783 & 1,243 \\
\cline { 2 - 5 } & 총계 & 480 & 892 & 1,372 \\
\hline \multirow{2}{*}{ 비중 } & 유상+MDB & 15.5 & 84.5 & 100 \\
\cline { 2 - 5 }$(\%)$ & 무상+UN & 37.0 & 63.0 & 100 \\
\cline { 2 - 5 } & 총계 & 35.0 & 65.0 & 100 \\
\hline
\end{tabular}

나. 사업 수

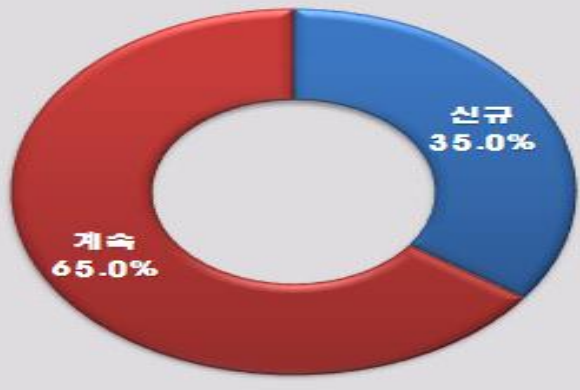




\section{2 양자협력 분야}

\section{1 유상협력 분야}

$\square$ (총괄) 31 개국 대상, 114 개 사업, 1 조 581 억원 차관 집행 추진

$\square$ (지역별) 아시아 중점지원 기조를 유지하되, 아프리카와 중동 · CIS, 중남미 지역으로 다변화 추진

이사시아(49.1\%), 아프리카(22.4\%), 중동.CIS(20.2\%), 중남미(8.4\%) 순

$\square$ (분야별) 개도국 민간부문의 경제활동을 촉진하는 분야 우선 지원 이교통(35.3\%), 수자원 · 위생(19.9\%), 보건(12.8\%), 공공행정(10.2\%), 에너지(6.9\%), 교육(6.4\%) 등

\section{2 무상협력 분야}

$\square$ (총괄) 84 개국 대상, 43 개 기관(지자체 11 개 포함), 1,189 개 사업, 1 조 5,709 억원 집행 추진

$\square$ (지역별) 아시아 중점지원 기조를 유지하되, 아프리카 지원 점진적 확대

아시아(26.1\%), 아프리카(15.7\%), 중남미(6.9\%), 중동.CIS(5.1\%), 오세아니아 $(1.2 \%)$ 순

$\square$ (분야별) 교육·보건 · 농림수산 · 인도적지원 등을 중심으로 지원

으교육(11.8\%), 보건(10.4\%), 농림수산(10.4\%), 인도적지원(10.0\%), 공공행정 $(10.0 \%)$, 산업에너지(5.4\%) 등

$\square$ (형태별) 프로젝트 사업 등 다양한 형태로 지원

○ 프로젝트(41.0\%), 봉사단(10.4\%), 연수사업 $(9.3 \%)$, 개발컨설팅 $(7.2 \%)$, 프로그램(7.0\%), 민관협력(5.0\%) 순

* (프로젝트) 66개국 대상 457건(6,442억), (개발컨설팅) 49개국 대상 156건 (1,127억), (해외봉사단) 53개국 대상 5,228명(1,630억) 추진, (연수사업 및 장학지원) 347 개 과정 15,581 명 $(1,455$ 억 $)$ 초청 


\section{3 다자협력 분야}

\section{1 국제금융기구}

$\square$ 국제금융기구에 대한 출자 · 출연은 약 $3,938.4$ 억원

에세부 유형별로는 증자 264.7억원, 양허성 기금 2,370.7억원, 신탁기금 1,303 억원 수준

< 출자·출연 계획 $($ 안) >

(단위: 억원)

\begin{tabular}{|c|c|c|c|c|}
\hline 구 분 & 증 자 & 양허성 기금 & 신 탁기 금(출연) & 합 계 \\
\hline WB & - & $1,642.0$ & 736.0 & 2,378.0 \\
\hline ADB & - & 246.9 & 218.5 & 465.4 \\
\hline AfDB & 22.7 & 355.3 & 138.0 & 516.0 \\
\hline IDB & 242.0 & - & 95.5 & 337.5 \\
\hline EBRD & - & - & 46.0 & 46.0 \\
\hline IMF & - & - & 34.5 & 34.5 \\
\hline GCF & - & 126.5 & - & 126.5 \\
\hline CABEI & - & - & 34.5 & 34.5 \\
\hline 합 계 & 264.7 & $2,370.7$ & $1,303.0$ & $3,938.4$ \\
\hline
\end{tabular}

* $\mathrm{AllB}$ 출자-출연 총액 1,719억원 추후 포함 예정('17.6월 OECD DAC 통계 작업반에서 $\mathrm{ODA}$ 적격기구로 합의, 계상비율 $85 \%$ 적용시 1,461 억원 인정 가능)

* 해당 기구와의 협의내용, 환율 변동 등에 따라 일부 변동 가능

\section{UN 및 기타 기구}

$\square$ 총 14 개 부처가 45 개 기구에 약 1,667 억원 기여(* 계상비율 미적용시 : 4,368억원)

이기구별 전문성 및 기존 협력관계 등을 종합적으로 고려하되, 주요 기구에 대한 기여 확대를 통해 선택과 집중 강화

$$
\text { < 주요 다자 기구별 지원계획(안) > }
$$

(단위 : 억원)

\begin{tabular}{c|c|c|c|c}
\hline UNDP & WHO & UNICEF & UNHCR & WFP \\
\hline 115 & 85.52 & 69 & 51.75 & 1.15 \\
\hline
\end{tabular}

* 여타 주요 지원계획 : 국제백신연구소(IVI) 114.26억원, 유엔여성기구(UN Women) 62.72억원, 국제식량농업기구(FAO) 55.35억원 등 


\section{첨부 1 2018년도 기관별 ODA 사업 예산 현황[요구 기준]}

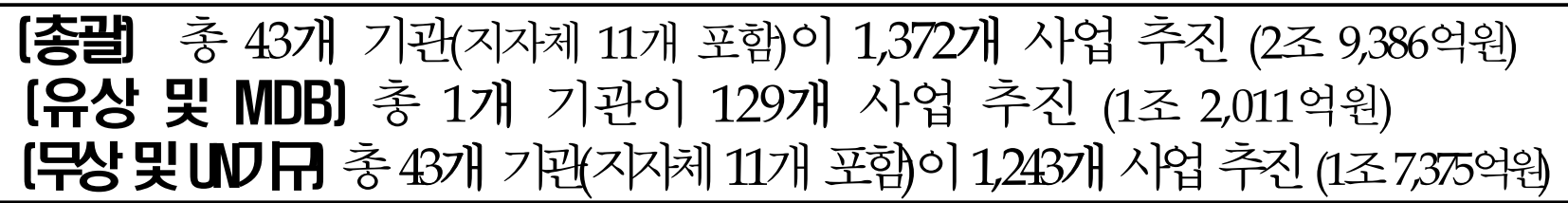

(단위 : 억원)

\begin{tabular}{|c|c|c|c|c|c|c|}
\hline \multirow{2}{*}{ 연 번 } & \multirow{2}{*}{ 시행 부처(기관) } & \multicolumn{3}{|c|}{ 2018년 } & \multicolumn{2}{|r|}{ 비 고 } \\
\hline & & 양자 & 다자 & 합계 & 사업수 & 사업 명 \\
\hline \multirow{2}{*}{1} & 국무조정실(본부) & 7.1 & 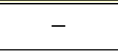 & 7.1 & 1 & 국제개발협력위원회 운영 \\
\hline & 경제인문사회연구회 & 117.3 & - & 117.3 & 24 & 국제기술혁신협력사업 등 \\
\hline \multirow{2}{*}{2} & 기획재정부(본부) & 585.3 & $1,429.5$ & $2,014.8$ & 54 & 국제금융기구(MDB), 경제발전경험공유사업(KSP) 등 \\
\hline & 수출입은행(EDCF) & $10,581.0$ & - & 10,581 & 114 & 우즈벡 타슈켄트 국제공항 신여객터미널 건설 등 \\
\hline 3 & 교육부 & 786.9 & - & 786.9 & 84 & 글로벌 코리아 스칼라십 등 \\
\hline 4 & 미래창조과학부 & 157.1 & 13.4 & 170.5 & 54 & 개도국 정보통신방송전문가 초청연수 등 \\
\hline \multirow{2}{*}{5} & 외교부(본부) & $2,924.3$ & $1,146.8$ & $4,071.1$ & 78 & 긴급구호 등 \\
\hline & 한국국제협력단 & $7,856.2$ & - & $7,856.2$ & 549 & 개도국 제도 구축사업(DEEP) 등 \\
\hline 6 & 법무부 & \multirow{2}{*}{$\begin{array}{l}10.8 \\
86.2\end{array}$} & - & 10.8 & 4 & 라오스 마약통제역량 강화 등 \\
\hline 7 & 행정자치부 & & - & 86.2 & 26 & 개도국 새마을 초청연수 등 \\
\hline 8 & 문화체육관광부 & 148.7 & - & 148.7 & 19 & 개도국 스포츠 발전 지원 등 \\
\hline 9 & 농림축산식품부 & 672.3 & 92.0 & 764.3 & 44 & 국제농업협력사업(ODA) 등 \\
\hline 10 & 산업통상자원부 & 455.4 & 14.4 & 469.8 & 42 & 즈벡 섬유테크노파크 조성사업 \\
\hline 11 & 보건복지부 & 390.7 & 225.0 & 615.7 & 39 & 국제백신연구소지원 등 \\
\hline 12 & 환경부 & 87.7 & 38 & 125.7 & 18 & 지구환경금융 부담금 등 \\
\hline 13 & 고용노동부 & 58.9 & 54.7 & 113.6 & 10 & 한-ILO 협력사업 등 \\
\hline 14 & 여성가족부 & 10.7 & 54.7 & 65.4 & 4 & 유엔여성기구기여금 등 \\
\hline 15 & 국토교통부 & 214.5 & 1.5 & 216 & 19 & 유엔 아프리카 자원공간정보 구축 등 \\
\hline 16 & 해양수산부 & 167.2 & - & 167.2 & 21 & 필리핀 해양수산 인프라 시설 구축 등 \\
\hline 17 & 국민안전처 & 18.5 & - & 18.5 & 4 & 재난안전 신기술 해외보급(ODA) 등 \\
\hline 18 & 인사혁신처 & 113.2 & - & 113.2 & 1 & 국제기구 고용휴직 제도운영 \\
\hline 19 & 식품의약품안전처 & 57.3 & - & 57.3 & 12 & 서태평양지역 개거도국불찰이원응약품 평가 및 \\
\hline 20 & 관세청 & 33.7 & 19.7 & 53.4 & 11 & 세계관세기구(WCO) 세관협력기금(CCF) 등 \\
\hline 21 & 통계청 & 32.1 & - & 32.1 & 7 & 라오스 통계역량강화사업 등 \\
\hline 22 & 경찰청 & 37.3 & - & 37.3 & 2 & 베트남 과학수사역량 강화사업 등 \\
\hline 23 & 문화재청 & 42.7 & 0.1 & 42.8 & 14 & 협력국 세계유산 보존관리 지원 등 \\
\hline 24 & 농촌진흥청 & 244.4 & 2.8 & 247.2 & 31 & 해외농업기술개발지원(KOPIA, 다자간 협의체 등) \\
\hline 25 & 산림청 & 143.6 & 3.0 & 146.6 & 15 & 아시아산림협력기구 협력사업 등 \\
\hline 26 & 중소기업청 & 9.5 & - & 9.5 & 2 & 최빈국 중소기업의 수출품질관리 역량 강화 \\
\hline 27 & 특허청 & 18.0 & 0.1 & 18.1 & 5 & WIPO 한국신탁기금 등 \\
\hline 28 & 기상청 & 35.4 & 0.7 & 36.1 & 7 & 미얀마 기상재해감시시스템 현대화 사업 등 \\
\hline 29 & 헌법재 판소 & 0.6 & - & 0.6 & 1 & 개발도상국 등 헌법재판기관 초청사업 \\
\hline 30 & 공정거래위원회 & 1.6 & - & 1.6 & 3 & UNCTAD 전문관 파견 등 \\
\hline 31 & 국민권익위원회 & 1.0 & - & 1 & 5 & 반부패 역량 강화 지원 등 \\
\hline 32 & 중앙선거관리위원회 & 68.5 & - & 68.5 & 10 & 선거관계자 역량강화 연수 등 \\
\hline 33 & 지방자치단체(11개) & 113.6 & - & 113.6 & 38 & 저개발국 새마을 시범마을 조성 등 \\
\hline & 합 계 & $26,289.3$ & $3,096.4$ & $29,385.7$ & 1,372 & \\
\hline
\end{tabular}

1) 양자협력 중 유상협력은 수출입은행(EDCF)에서만 시행(1조 581억원)

2) 다자협력 중 국제금융기구 출자금 265 억원, 양허성기금 2,244 억원은 ODA 총규모에는 포함되나, 기관별 사업예산에는 미포함

3) 다자협력 충 UN 및 기타기구 지원액은 ODA 계상비율에 따라 ODA로 인정되는 액수만을 포함 


\section{국무조정실 2018년도 ODA 예산 계획[안]}

$\square$ 총괄

(단위: 억원)

\begin{tabular}{l|c|c|c||c|c|c}
\hline \multirow{2}{*}{$\mathrm{ODA}$ 시행부처(기관) } & \multicolumn{3}{|c||}{2017} & \multicolumn{3}{c}{2018 (요구) } \\
\cline { 2 - 7 } & 양자 무상 & 다자 & 합계 & 양자 무상 & 다자 & 합계 \\
\hline 국무조정실 & 64.4 & - & 64.4 & 124.4 & - & 124.4 \\
\hline
\end{tabular}

※ 다자성양자는 양자에 포함

○ '18년도 ODA 시행목표

- 전략적·체계적 $\mathrm{ODA}$ 추진을 위한 정책 수립 및 제도 개선

우주요 정책과제

- ODA 사업의 투명성·효과성 제고를 위한 정책 및 제도 개선

- 국책연구기관의 전문성을 활용하여 수원국 정책 수립 및 집행 역량 배양 지원

유형별 분류

(억 원, \%)

\begin{tabular}{|c|c|c|c|c|c|c|c|c|c|c|c|c|}
\hline \multirow[b]{2}{*}{ 구분 } & \multirow[b]{2}{*}{ 계 } & \multirow[b]{2}{*}{$\begin{array}{l}\text { 프로 } \\
\text { 젝트 }\end{array}$} & \multirow[b]{2}{*}{$\begin{array}{l}\text { 프로 } \\
\text { 그램 }\end{array}$} & \multirow[b]{2}{*}{$\begin{array}{l}\text { 개발 } \\
\text { 컨설팅 }\end{array}$} & \multicolumn{4}{|c|}{ 기술협력 } & \multirow{2}{*}{$\begin{array}{c}\text { 민관 } \\
\text { 협력 } \\
\text { (NGO, } \\
\text { 기업) }\end{array}$} & \multirow[b]{2}{*}{$\begin{array}{l}\text { 행정 } \\
\text { 비용 }\end{array}$} & \multirow[b]{2}{*}{ 기타 } & \multirow[b]{2}{*}{$\begin{array}{l}\text { 순수 } \\
\text { 다자* }\end{array}$} \\
\hline & & & & & $\begin{array}{l}\text { 연수 } \\
\text { 사업 }\end{array}$ & $\begin{array}{l}\text { 장학 } \\
\text { 지원 }\end{array}$ & $\begin{array}{l}\text { 봉사단 } \\
\text { 파견 }\end{array}$ & $\begin{array}{l}\text { 기타 } \\
\text { 기술 } \\
\text { 협력 }\end{array}$ & & & & \\
\hline \multirow{2}{*}{ '17년 } & 64.4 & $\therefore$ & $\therefore$ & 14.9 & - & 11.4 & - & 31.5 & - & 6.6 & - & - \\
\hline & 100 & - & - & 23.1 & - & 17.7 & - & 49.0 & - & 10.2 & - & - \\
\hline '18년 & 124.4 & 11.7 & - & 17.7 & 49.1 & 14.4 & - & 24.5 & - & 7.1 & - & - \\
\hline (요구) & 100 & 9.4 & $\begin{array}{l}\cdots \\
-\end{array}$ & 14.2 & 39.4 & 11.6 & $\begin{array}{l}\cdots \\
-\end{array}$ & 19.7 & $\begin{array}{l}\cdots \\
-\end{array}$ & 5.7 & $\cdots$ & $\begin{array}{l}\cdots \\
-\end{array}$ \\
\hline
\end{tabular}

* 다자성양자를 제외한 순수다자만 해당되며, 다자성양자는 사업 유형에 맞게 분류

$\square$ 총 사업 목록

\begin{tabular}{|c|c|c|c|c|c|c|c|c|c|}
\hline & 세부사업명 & 내역사업명 & 사업 유형 & $\begin{array}{l}\begin{array}{c}\text { 총사업예산 } \\
\text { (억원) }\end{array} \\
\end{array}$ & $\begin{array}{l}18 \text { 년 예산 } \\
\text { (억원) }\end{array}$ & $\begin{array}{l}\text { 신규/ } \\
\text { 계속 }\end{array}$ & $\begin{array}{l}\text { 총사업 } \\
\text { 기간 }\end{array}$ & $\begin{array}{c}\text { 구분 } \\
\text { (양-다자) }\end{array}$ & $\begin{array}{l}\text { SDGS } \\
\text { 목표 }\end{array}$ \\
\hline 1 & $\begin{array}{l}\text { 국제개발협력위원회 } \\
\text { 운영 }\end{array}$ & $\begin{array}{l}\text { 국제개발협력위원회 } \\
\text { 운영 }\end{array}$ & 행정비용 & & 7.10 & 계속 & 2011-계속 & 양자무상 & \\
\hline 2 & $\begin{array}{l}\text { 개도국 인벤토리•감축 } \\
\text { 모형 전문가 양성 프 } \\
\text { 로그램 }\end{array}$ & $\begin{array}{l}\text { 국제 온실가스 전문가 } \\
\text { 양성과정 }\end{array}$ & 연수사업 & 3.40 & 3.40 & 신규 & 2018 & 양자무상 & 13 \\
\hline 3 & 국제기술혁신협력사업 & $\begin{array}{l}\text { 국제기술혁신협력사업 } \\
\text { (에티오피아) }\end{array}$ & 개발컨설팅 & 54.78 & 9.70 & 계속 & $2014-2018$ & 양자무상 & 9 \\
\hline 4 & 국제기술혁신협력사업 & $\begin{array}{l}\text { 국제기술혁신협력사업 } \\
\text { (탄자니아) }\end{array}$ & 개발컨설팅 & 3.00 & 1.50 & 신규 & $2018-2019$ & 양자무상 & 9 \\
\hline 5 & 국제기술혁신협력사업 & $\begin{array}{l}\text { 국제기술혁신협력사업 } \\
\text { (튀니지) }\end{array}$ & 개발컨설팅 & 3.00 & 1.50 & 신규 & $2018-2019$ & 양자무상 & 9 \\
\hline 6 & 국제기술혁신협력사업 & $\begin{array}{l}\text { 국제기술혁신협력사업 } \\
\text { (캄보디아) }\end{array}$ & 개발컨설팅 & 3.00 & 1.50 & 신규 & $2018-2019$ & 양자무상 & 9 \\
\hline 7 & 국제기술혁신협력사업 & $\begin{array}{l}\text { 국제기술혁신협력사업 } \\
\text { (우간다) }\end{array}$ & 개발컨설팅 & 4.00 & 2.00 & 신규 & $2018-2019$ & 양자무상 & 9 \\
\hline
\end{tabular}




\begin{tabular}{|c|c|c|c|c|c|c|c|c|c|}
\hline & 세부사업명 & 내역사업명 & 사업 유형 & $\begin{array}{l}\begin{array}{c}\text { 총사업예산 } \\
\text { (억원) }\end{array} \\
\text { (1) }\end{array}$ & $\begin{array}{l}\text { '18년예산 } \\
\text { (억원) }\end{array}$ & $\begin{array}{l}\text { 신규/ } \\
\text { 계속 } \\
\end{array}$ & $\begin{array}{l}\text { 총사업 } \\
\text { 기간 }\end{array}$ & $\begin{array}{c}\text { 구분 } \\
\text { (양-다자) } \\
\end{array}$ & $\begin{array}{l}\text { SDGs } \\
\text { 목표 }\end{array}$ \\
\hline 8 & 국제기술혁신협력사업 & $\begin{array}{l}\text { 국제기술혁신협력사업 } \\
\text { (인도네시아) }\end{array}$ & 개발컨설팅 & 3.00 & 1.50 & 신규 & $2018-2019$ & 양자무상 & 9 \\
\hline 9 & 국제기술혁신협력사업 & $\begin{array}{l}\text { 국제기술혁신협력사업 } \\
\text { (스리랑카) }\end{array}$ & 연수사업 & 1.00 & 1.00 & 신규 & 2018 & 양자무상 & 9 \\
\hline 10 & 국제기술혁신협력사업 & $\begin{array}{l}\text { 국제기술혁신협력사업 } \\
\text { (아제르바이잔) }\end{array}$ & 기타기술협력 & 1.00 & 1.00 & 신규 & 2018 & 양자무상 & 9 \\
\hline & $\begin{array}{l}\text { 한-OECD 국제개발 } \\
\text { 협력사업 }\end{array}$ & $\begin{array}{l}\text { (1)아-태지역 개도 } \\
\text { 국 조세공무원 및 전 } \\
\text { 문가를 대상으로 조세 } \\
\text { 조약, 이전가격세제 } \\
\text { 등 조세정책 교육연수 }\end{array}$ & 연수사업 & 12.06 & 12.06 & 신규 & 2018년 & 양자무상 & 1 \\
\hline & $\begin{array}{l}\text { 한-OECD 국제개발 } \\
\text { 협력사업 }\end{array}$ & $\begin{array}{l}\text { (2)아. 태지역개도국 } \\
\text { 경쟁당국·산업별규제 } \\
\text { 당국공무원및판사등을 } \\
\text { 대상으로카르텔. 기업 } \\
\text { 결합. 시장지배적지위 } \\
\text { 남용행위규제,경쟁주 } \\
\text { 창등의OECD선진경쟁 } \\
\text { 정책교육연수 }\end{array}$ & 연수사업 & 8.24 & 8.24 & 신규 & 2018년 & 양자무상 & 1 \\
\hline & $\begin{array}{l}\text { 한-OECD 국제개발 } \\
\text { 협력사업 }\end{array}$ & $\begin{array}{l}\text { (3)아-태지역 개도 } \\
\text { 국 공공거버넌스 관 } \\
\text { 련 공무원을 대상으로 } \\
\text { 공공혁신, 민관협력, } \\
\text { 지방재정 등에 관한 } \\
\text { 역랼강화 프로그램 및 } \\
\text { 아시아공공거버넌스 } \\
\text { 포럼 }\end{array}$ & 연수사업 & 5.38 & 5.38 & 신규 & 2018년 & 양자무상 & 1 \\
\hline & $\begin{array}{l}\text { 한-OECD 국제개발 } \\
\text { 협력사업 }\end{array}$ & $\begin{array}{l}\text { (4)아-태지역 개도 } \\
\text { 국 보건, 사회, 연금 } \\
\text { 분야 공무원 및 전문 } \\
\text { 가를 대상으로 선진제 } \\
\text { 도 전문가회의 교육 } \\
\text { 연수 }\end{array}$ & 연수사업 & 8.81 & 8.81 & 신규 & 2018년 & 양자무상 & 1 \\
\hline & $\begin{array}{l}\text { 국제학생 학위과정 초 } \\
\text { 청연수 }\end{array}$ & $\begin{array}{l}\text { 국제학생 학위과정 초 } \\
\text { 청연수 }\end{array}$ & 장학지원 & 114.60 & 14.40 & 계속 & 계속 & 양자무상 & 4 \\
\hline & $\begin{array}{l}\text { 국제개발협력역량강화 } \\
\text { 사업 }\end{array}$ & 세계개발교육네트워크 & 기타기술협력 & 17.22 & 2.17 & 계속 & 2012-계속 & 양자무상 & 17 \\
\hline & $\begin{array}{l}\text { 국제개발협력역량강화 } \\
\text { 사업 }\end{array}$ & $\begin{array}{l}\text { 중남미공공정책및관리 } \\
\text { 역량강화사업 }\end{array}$ & 연수사업 & 13.98 & 2.16 & 계속 & $2013-2020$ & 양자무상 & 17 \\
\hline & $\begin{array}{l}\text { 국제개발협력 역량강 } \\
\text { 화사업 }\end{array}$ & $\begin{array}{l}\text { 경제협력국과의 협력 } \\
\text { 관계제고 역량강화사 } \\
\text { 업 }\end{array}$ & 기타기술협력 & 16.72 & 2.32 & 계속 & 2012-계속 & 양자무상 & 17 \\
\hline & $\begin{array}{l}\text { 국제개발협력 역량강 } \\
\text { 화사업 }\end{array}$ & $\begin{array}{l}\text { 국제개발협력 전문가 } \\
\text { 역량강화사업 }\end{array}$ & 기타기술협력 & 5.52 & 5.52 & 신규 & 2018 & 양자무상 & 17 \\
\hline 20 & $\begin{array}{l}\text { 세계은행과의 공동사 } \\
\text { 업 }\end{array}$ & 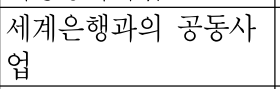 & 기타기술협력 & 10.47 & 10.47 & 신규 & 2018 & 다자성양자 & 17 \\
\hline & $\begin{array}{l}\text { 감보디아 초등교원 역 } \\
\text { 량 강화 연수 사업 : } \\
\text { 여학생 교육의 질 제 } \\
\text { 고를 중심으로 }\end{array}$ & $\begin{array}{l}\text { 캄보디아 초등교원 역 } \\
\text { 량 강화 연수 사업 : } \\
\text { 여학생 교육의 질 제 } \\
\text { 고를 중심으로 }\end{array}$ & 연수사업 & 9.00 & 3.00 & 신규 & 2018 2020 & 양자무상 & 4 \\
\hline & $\begin{array}{l}\text { 아시아 중점협력국의 } \\
\text { 지속가능개발목표 } \\
\text { (Sustainable } \\
\text { Development Goals) } \\
\text { 달성을 위한 양성평등 } \\
\text { 정책기반 강화 사업 }\end{array}$ & $\begin{array}{l}\text { 아시아 중점협력국의 } \\
\text { 지속가능개발목표 } \\
\text { (Sustainable } \\
\text { Development Goals) } \\
\text { 달성을 위한 양성평등 } \\
\text { 정책기반 강화 사업 }\end{array}$ & 연수사업 & 20.00 & 5.00 & 신규 & $2018-2021$ & 양자무상 & 5 \\
\hline & $\begin{array}{l}\text { 국제환경평가 교류협 } \\
\text { 력사업 }\end{array}$ & 국제환경평가 교류협 & 기타기술협력 & 3.00 & 3.00 & 계속 & 2018 & 양자무상 & 15 \\
\hline & $\begin{array}{l}\text { 최빈국 기후변화적응 } \\
\text { 역량 강화 사업 }\end{array}$ & $\begin{array}{l}\text { 최빈국 기후변화적응 } \\
\text { 역량 강화 사업 }\end{array}$ & 프로젝트 & 12.00 & 4.00 & 신규 & $2018-2021$ & 다자성양자 & 13 \\
\hline & $\begin{array}{l}\text { 파라과이환경영향평가 } \\
\text { 지원시스템을위한정보 } \\
\text { 화플랫폼구축 }\end{array}$ & $\begin{array}{l}\text { 파라과이환경영향평가 } \\
\text { 지원시스템을위한정보 } \\
\text { 화플랫폼구축 }\end{array}$ & 프로젝트 & 23.00 & 7.66 & 신규 & $2018-2020$ & 양자무상 & 15 \\
\hline
\end{tabular}




\section{기획재정부 2018년도 ODA 예산 계획[안]}

(단위: 억원)

\begin{tabular}{l|c|c|c|c||c|c|c|c}
\hline \multirow{2}{*}{ ODA 시행부처(기관) } & \multicolumn{4}{|c||}{2017} & \multicolumn{4}{c}{ 2018(요구) } \\
\cline { 2 - 9 } & 양자무상 & 양자유상 & 다자 & 합계 & 양자무상 & 양자유상 & 다자 & 합계 \\
\hline 기획재정부 & 405 & 9,545 & 1,163 & 11,113 & 585.3 & 10,581 & $1,429.5$ & $12,595.8$ \\
\hline
\end{tabular}

※ 다자성양자는 양자에 포함

○ '18년도 ODA 시행목표

- 유상분야 운용에 있어 1 조 8,000 억원 규모의 신규사업을 승인하고, 31 개국을 대상으로 114 개 사업의 개도국 차관 및 $\mathrm{MDB}$ 협조융자 차관 집행(10,581억원)

- 아프리카 및 중남미 등 신흥국에 대한 $\mathrm{EDCF}$ 지원을 강화하여 우리 기업의 해외진출 촉진 등 상생의 국제개발협력 추진

으주요 정책과제

- 개도국 경제성장 및 인프라 개발을 위해 SDG 적극 이행

- 개발효과성이 높고 우리 기업·인력 진출에 기여하는 대규모·랜드마크형 인프라 개발사업과 개발금융 및 $\mathrm{PPP}$ 활성화 등 민간부문의 참여 확대 추진

- 해외사무소 청년 인턴 파견 등을 통해 지역전문가 양성 등 지원

- 개발도상국 및 신흥경제국을 대상으로 우리의 경제발전경험을 공유하고, 현지에 적합한 정책 대안(Policy Option)을 제시

- 국제기구 협력강화 및 한국개발경험 공유를 위한 국제기구 신탁기금 운용

$\square$ 유형별 분류

(억원, \%)

\begin{tabular}{|c|c|c|c|c|c|c|c|c|c|c|c|c|}
\hline \multirow[b]{2}{*}{ 구분 } & \multirow[b]{2}{*}{ 계 } & \multirow[b]{2}{*}{$\begin{array}{l}\text { 프로 } \\
\text { 젝트 }\end{array}$} & \multirow[b]{2}{*}{$\begin{array}{l}\text { 프로 } \\
\text { 그램 }\end{array}$} & \multirow[b]{2}{*}{$\begin{array}{l}\text { 개발 } \\
\text { 컨설팅 }\end{array}$} & \multicolumn{4}{|c|}{ 기술협력 } & \multirow{2}{*}{$\begin{array}{c}\text { 민관 } \\
\text { 협력 } \\
\text { (NGO, } \\
\text { 기업) }\end{array}$} & \multirow[b]{2}{*}{$\begin{array}{l}\text { 행정 } \\
\text { 비용 }\end{array}$} & \multirow[b]{2}{*}{ 기타 } & \multirow[b]{2}{*}{$\begin{array}{l}\text { 순수 } \\
\text { 다자* }\end{array}$} \\
\hline & & & & & $\begin{array}{l}\text { 초청 } \\
\text { 연수 }\end{array}$ & $\begin{array}{l}\text { 장학 } \\
\text { 지원 }\end{array}$ & $\begin{array}{l}\text { 봉사단 } \\
\text { 파견 }\end{array}$ & $\begin{array}{l}\text { 기타 } \\
\text { 기술 } \\
\text { 협력 }\end{array}$ & & & & \\
\hline \multirow{2}{*}{ '17년 } & 11,113 & $9,683.6$ & - & 69.3 & - & - & - & - & - & 187.5 & 9.6 & 1,163 \\
\hline & 100 & 87.2 & - & 0.6 & - & - & - & - & - & 1.7 & 0.1 & 10.4 \\
\hline '18년 & $12,595.8$ & 10,834 & & 124.3 & - & - & - & - & - & 194 & 14 & $1,429.5$ \\
\hline (요구) & 100 & 86.0 & & 0.9 & & & & & & 1.5 & 0.1 & 11.3 \\
\hline
\end{tabular}

* 다자성양자를 제외한 순수다자만 해당되며, 다자성양자는 사업 유형에 맞게 분류

$\square$ 총 사업 목록

\begin{tabular}{|c|c|c|c|c|c|c|c|c|c|}
\hline & 세부사업명 & 내역사업 명 & 사업 유형 & $\begin{array}{l}\text { 총사업 예산 } \\
\text { (억원) }\end{array}$ & $\begin{array}{l}\text { ‘18년예산 } \\
\text { (억원) }\end{array}$ & $\begin{array}{l}\text { 신규/ } \\
\text { 계속 }\end{array}$ & $\begin{array}{l}\text { 총사업 } \\
\text { 기간 }\end{array}$ & $\begin{array}{c}\text { 구분 } \\
\text { (양-다자) }\end{array}$ & $\begin{array}{l}\text { SDGs } \\
\text { 목표 }\end{array}$ \\
\hline 1 & 아시아차관 & $\begin{array}{l}\text { 라오스 조세정보시 } \\
\text { 스템 구축사업 }\end{array}$ & 프로젝트 & 323.44 & 26.72 & 계속 & $2012 \sim 2018$ & 양자유상 & 9 \\
\hline 2 & 아시아차관 & $\begin{array}{l}\text { 라오스 사반나켓주 } \\
\text { 농촌종합개발사업 }\end{array}$ & 프로젝트 & 526.99 & 42.32 & 계속 & 2020 & 양자유상 & 2 \\
\hline 3 & 아시아차관 & 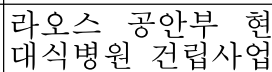 & 프로젝트 & 744.67 & 6.29 & 계속 & 2023 & 양자유상 & 3 \\
\hline
\end{tabular}




\begin{tabular}{|c|c|c|c|c|c|c|c|c|c|}
\hline & 세부사업명 & 내역사업명 & 사업 유형 & $\begin{array}{l}\text { 총사업 예산 } \\
\text { (억원) }\end{array}$ & $\begin{array}{l}\text { 18년예산 } \\
\text { (억원) }\end{array}$ & $\begin{array}{l}\text { 신규/ } \\
\text { 계속 }\end{array}$ & $\begin{array}{l}\text { 총사업 } \\
\text { 기간 }\end{array}$ & $\begin{array}{c}\text { 구분 } \\
\text { (양-다자) }\end{array}$ & $\begin{array}{l}\text { SDGs } \\
\text { 목표 }\end{array}$ \\
\hline 4 & 아시아차관 & \begin{tabular}{|l|} 
라오스스비엔티안시 \\
메 콩강병합관리 \\
사업(2차)
\end{tabular} & 프로젝트 & 659.95 & 7.87 & 신규 & $2017 \sim 2023$ & 양자유상 & 2 \\
\hline 5 & 아시아차관 & $\begin{array}{l}\text { 몽골 국립의료원 } \\
\text { 건립사업 }\end{array}$ & 프로젝트 & 650.20 & 42.17 & 계속 & $2014 \sim 2019$ & 양자유상 & 3 \\
\hline 6 & 아시아차관 & 몽골 시외버스 교체사업 & 프로젝트 & 33.87 & 1.45 & 신규 & $2016 \sim 2019$ & 양자유상 & 11 \\
\hline 7 & 아시아차관 & 몽골 국제버스 교체사업 & 프로젝트 & 33.87 & 1.45 & 신규 & $2016 \sim 2019$ & 양자유상 & 11 \\
\hline 8 & 아시아차관 & $\begin{array}{l}\text { 몽골 시외버스 교체 } \\
\text { 사업 2차 }\end{array}$ & 프로젝트 & 286.41 & 25.30 & 신규 & $2017 \sim 2019$ & 양자유상 & 11 \\
\hline 9 & 아시아차관 & \begin{tabular}{|l|} 
몽골 ICT통합교실 \\
구축아업
\end{tabular} & 프로젝트 & 224.65 & 18.13 & 신규 & $2017 \sim 2019$ & 양자유상 & 4 \\
\hline 10 & 아시아차관 & \begin{tabular}{|l|l|}
$\begin{array}{l}\text { 미얀마 철도현대화 } \\
\text { 사업 }\end{array}$ &
\end{tabular} & 프로젝트 & 515.54 & 149.01 & 계속 & $2017 \sim 2020$ & 양자유상 & 9 \\
\hline 11 & 아시아차관 & $\begin{array}{l}\text { 미얀마 한-미얀마 } \\
\text { 우정의 다리 건설 } \\
\text { 사업 }\end{array}$ & 프로젝트 & $1,579.07$ & 275.42 & 계속 & $2017 \sim 2022$ & 양자유상 & 9 \\
\hline 12 & 아시아차관 & $\begin{array}{l}\text { 미얀마 뚠때 운하 } \\
\text { 개선사업 }\end{array}$ & 프로젝트 & 702.28 & 10.85 & 계속 & $2017 \sim 2022$ & 양자유상 & 9 \\
\hline 13 & 아시아차관 & \begin{tabular}{|l|} 
방글라데시 다카 \\
상수도 개발사업
\end{tabular} & 프로젝트 & 469.06 & 16.87 & 계속 & $2013 \sim 2018$ & 양자유상 & 6 \\
\hline 14 & 아시아차관 & $\begin{array}{l}\text { 방글라데시 해상안 } \\
\text { 전 운항시스템 구 } \\
\text { 축사업 }\end{array}$ & 프로젝트 & 429.62 & 185.56 & 계속 & $2014 \sim 2019$ & 양자유상 & 9 \\
\hline 15 & 아시아차관 & $\begin{array}{l}\text { 방글라데시 광대역 } \\
\text { 무선통신망 구축사업 }\end{array}$ & 프로젝트 & 882.14 & 187.73 & 계속 & $2015 \sim 2018$ & 양자유상 & 9 \\
\hline 16 & 아시아차관 & \begin{tabular}{|l|} 
방글라데시 반달쥬리 \\
상수도 개 발사업
\end{tabular} & 프로젝트 & $1,111.27$ & 81.11 & 계속 & $2017 \sim 2020$ & 양자유상 & 6 \\
\hline 17 & 아시아차관 & \begin{tabular}{|l|} 
방글라데시 BSM의대 \\
종합 전문센터병원 \\
건립사업
\end{tabular} & 프로젝트 & $1,499.84$ & 64.97 & 계속 & $2016 \sim 2020$ & 양자유상 & 3 \\
\hline 18 & 아시아차관 & $\begin{array}{ll}\text { 베트남 티엔탄 } & \text { 상 } \\
\text { 수돋사업(2차) } & \text { 보 } \\
\text { 충융자 } & \end{array}$ & 프로젝트 & 167.46 & 31.85 & 계속 & $2017 \sim 2018$ & 양자유상 & 6 \\
\hline 19 & 아시아차관 & $\begin{array}{l}\text { 베트남 비엣찌 하 } \\
\text { 수도 건설사업 }\end{array}$ & 프로젝트 & 341.04 & 46.70 & 계속 & $2012 \sim 2019$ & 양자유상 & 6 \\
\hline 20 & 아시아차관 & $\begin{array}{l}\text { 베트남 목짜우 상 } \\
\text { 하수도 건설사업 }\end{array}$ & 프로젝트 & 145.10 & 29.57 & 계속 & $2011 \sim 2020$ & 양자유상 & 6 \\
\hline 21 & 아시아차관 & $\begin{array}{l}\text { 베트남 옌바이 종 } \\
\text { 합병원 건립사업 }\end{array}$ & 프로젝트 & 498.66 & 16.87 & 계속 & $2011 \sim 2018$ & 양자유상 & 3 \\
\hline 22 & 아시아차관 & $\begin{array}{l}\text { 베트남 꽝빈성 태 } \\
\text { 양광 발전사업 }\end{array}$ & 프로젝트 & 134.82 & 41.33 & 계속 & $2012 \sim 2019$ & 양자유상 & 7 \\
\hline 23 & 아시아차관 & $\begin{array}{l}\text { 베트남 롱수옌시 } \\
\text { 하수처리사업 }\end{array}$ & 프로젝트 & 538.95 & 68.43 & 계속 & $2013 \sim 2019$ & 양자유상 & 6 \\
\hline 24 & 아시아차관 & $\begin{array}{l}\text { 베트남 로때-락소 } \\
\text { 이 고속도로 건설 } \\
\text { 사업 }\end{array}$ & 프로젝트 & $2,348.27$ & 151.84 & 계속 & $2015 \sim 2022$ & 양자유상 & 9 \\
\hline 25 & 아시아차관 & $\begin{array}{l}\text { 베트남 국립이비인 } \\
\text { 후과병원 의료기자 } \\
\text { 재 공급사업 }\end{array}$ & 프로젝트 & 217.67 & 94.48 & 계속 & $2017 \sim 2019$ & 양자유상 & 3 \\
\hline 26 & 아시아차관 & $\begin{array}{l}\text { 베트남 하노이 약 } \\
\text { 학대학 건립사업 }\end{array}$ & 프로젝트 & 515.54 & 16.87 & 계속 & $2016 \sim 2020$ & 양자유상 & 4 \\
\hline 27 & 아시아차관 & $\begin{array}{l}\text { 베트남 흥하교량 } \\
\text { 건설사업 }\end{array}$ & 프로젝트 & $1,344.54$ & 101.23 & 계속 & $2015 \sim 2019$ & 양자유상 & 9 \\
\hline 28 & 아시아차관 & $\begin{array}{l}\text { 베트남 틴롱교량 } \\
\text { 건설사업 }\end{array}$ & 프로젝트 & 526.99 & 50.61 & 계속 & $2016 \sim 2020$ & 양자유상 & 9 \\
\hline 29 & 아시아차관 & $\begin{array}{l}\text { 베트남 안지앙성 탄짜 } \\
\text { 우 종햅병원 의료가자재 } \\
\text { 공급사업 }\end{array}$ & 프로젝트 & 34.37 & 23.40 & 계속 & $2017 \sim 2019$ & 양자유상 & 3 \\
\hline 30 & 아시아차관 & $\begin{array}{l}\text { 베 트남 짜빈성 튜껀 종 } \\
\text { 합병원 앞 의료기자 } \\
\text { 재 공급사업 }\end{array}$ & 프로젝트 & 34.37 & 23.40 & 계속 & $2017 \sim 2019$ & 양자유상 & 3 \\
\hline 31 & 아시아차관 & $\begin{array}{|ll|}\text { 베트남 렌강 및 황 } \\
\text { 마이강 수자원 개 } \\
\text { 발사업 }\end{array}$ & 프로젝트 & 881.39 & 153.36 & 계속 & $2017 \sim 2021$ & 양자유상 & 6 \\
\hline 32 & 아시아차관 & \begin{tabular}{|l|} 
베트남 하이퐁시 산 \\
부인과 병원 의료기 \\
자재 공급사업
\end{tabular} & 프로젝트 & 34.37 & 23.40 & 계속 & $2017 \sim 2019$ & 양자유상 & 3 \\
\hline
\end{tabular}




\begin{tabular}{|c|c|c|c|c|c|c|c|c|c|}
\hline & 세부사업명 & 내역사업명 & 사업 유형 & $\begin{array}{c}\text { 총사업예산 } \\
\text { (억원) }\end{array}$ & $\begin{array}{c}18 \text { 년예산 } \\
\text { (억원) }\end{array}$ & $\begin{array}{l}\text { 신규/ } \\
\text { 계속 }\end{array}$ & $\begin{array}{l}\text { 총사업 } \\
\text { 기간 }\end{array}$ & $\begin{array}{c}\text { 구분 } \\
\text { (양·다자) }\end{array}$ & $\begin{array}{l}\text { SDGS } \\
\text { 목표 }\end{array}$ \\
\hline 33 & 아시아차관 & $\begin{array}{l}\text { 베트남 소방방재청 } \\
\text { 재난안전설비 개선 } \\
\text { 사업 }\end{array}$ & 프로젝트 & 229.13 & 152.21 & 계속 & $2017 \sim 2020$ & 양자유상 & 11 \\
\hline 34 & 아시아차관 & $\begin{array}{l}\text { 베트남 짜빈상수도 } \\
\text { 건설사업 }\end{array}$ & 프로젝트 & 295.44 & 10.42 & 계속 & $2017 \sim 2021$ & 양자유상 & 6 \\
\hline 35 & 아시아차관 & 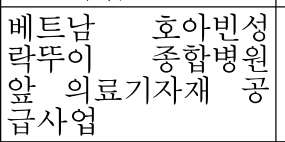 & 프로젝트 & 34.37 & 16.87 & 계속 & $2017 \sim 2019$ & 양자유상 & 3 \\
\hline 36 & 아시아차관 & $\begin{array}{l}\text { 베트남 하띤성 둑토 } \\
\text { 종합병 원 앞 의료기 } \\
\text { 자재 공급사업 }\end{array}$ & 프로젝트 & 34.37 & 16.87 & 계속 & $2017 \sim 2019$ & 양자유상 & 3 \\
\hline 37 & 아시아차관 & $\begin{array}{l}\text { 베트남 뀌년시 메 } \\
\text { 디컬센턴 앞의료기 } \\
\text { 자재 공급사업 }\end{array}$ & 프로젝트 & 34.37 & 16.87 & 계속 & $2017 \sim 2019$ & 양자유상 & 3 \\
\hline 38 & 아시아차관 & $\begin{array}{l}\text { 베트남 벤째성 종합 } \\
\text { 병원 건립사업 }\end{array}$ & 프로젝트 & 717.89 & 84.35 & 계속 & $2017 \sim 2020$ & 양자유상 & 3 \\
\hline 39 & 아시아차관 & $\begin{array}{l}\text { 베트남 케넷 철도 } \\
\text { 개량사업 }\end{array}$ & 프로젝트 & 869.49 & 80.98 & 신규 & $2017 \sim 2023$ & 양자유상 & 9 \\
\hline 40 & 아시아차관 & $\begin{array}{l}\text { 베트남 노후 교량 } \\
\text { 개보수사업(1차) }\end{array}$ & 프로젝트 & 601.33 & 55.67 & 신규 & $2017 \sim 2022$ & 양자유상 & 9 \\
\hline 41 & 아시아차관 & $\begin{array}{l}\text { 스리랑카 고체폐기 } \\
\text { 물 매립장 건립사 } \\
\text { 업 }\end{array}$ & 프로젝트 & 384.20 & 38.23 & 계속 & $2014 \sim 2019$ & 양자유상 & 6 \\
\hline 42 & 아시아차관 & $\begin{array}{l}\text { 스리랑카 데두루 } \\
\text { 오야 상수도 사업 }\end{array}$ & 프로젝트 & 640.38 & 69.17 & 계속 & $2016 \sim 2019$ & 양자유상 & 6 \\
\hline 43 & 아시아차관 & \begin{tabular}{|l|} 
스리랑카 루완웰라 \\
상수도 사업
\end{tabular} & 프로젝트 & 235.20 & 18.55 & 계속 & $2017 \sim 2020$ & 양자유상 & 6 \\
\hline 44 & 아시아차관 & $\begin{array}{l}\text { 캄보디아 21번 국 } \\
\text { 도 개보수사업 }\end{array}$ & 프로젝트 & 588.57 & 59.21 & 계속 & $2013 \sim 2018$ & 양자유상 & 9 \\
\hline 45 & 아시아차관 & $\begin{array}{l}\text { 캄보디아 살라타온 } \\
\text { 댐 개발사업 }\end{array}$ & 프로젝트 & 419.84 & 35.46 & 계속 & $2015 \sim 2019$ & 양자유상 & 6 \\
\hline 46 & 아시아차관 & $\begin{array}{l}\text { 캄보디아 2번 22번 } \\
\text { 국도 개보수 사업 }\end{array}$ & 프로젝트 & 642.70 & 96.03 & 계속 & $2017 \sim 2019$ & 양자유상 & 9 \\
\hline 47 & 아시아차관 & $\begin{array}{l}\text { 캄보디아 } 48 \text { 번 국 } \\
\text { 도 개보수 사업 }\end{array}$ & 프로젝트 & 772.55 & 115.61 & 계속 & $2017 \sim 2020$ & 양자유상 & 9 \\
\hline 48 & 아시아차관 & $\begin{array}{l}\text { 캄보디아 타크마우 하 } \\
\text { 수처리 구축 및 하 } \\
\text { 천정비사업 }\end{array}$ & 프로젝트 & 731.90 & 8.89 & 계속 & $2017 \sim 2023$ & 양자유상 & 6 \\
\hline 49 & 아시아차관 & $\begin{array}{l}\text { 캄보디아 반테민체이 } \\
\text { 관개 개발 및 홍수 피 } \\
\text { 해 저감 사업 }\end{array}$ & 프로젝트 & 974.88 & 12.29 & 신규 & $2017 \sim 2023$ & 양자유상 & 2 \\
\hline 50 & 아시아차관 & \begin{tabular}{|l|} 
파키스탄 말라칸트 \\
터널 건설사업
\end{tabular} & 프로젝트 & 893.60 & 131.41 & 계속 & $2016 \sim 2023$ & 양자유상 & 9 \\
\hline 51 & 아시아차관 & \begin{tabular}{|l|r|} 
파키스탄닌드주 \\
아동원 건립사업
\end{tabular} & 프로젝트 & 526.99 & 92.23 & 계속 & $2017 \sim 2020$ & 양자유상 & 3 \\
\hline 52 & 아시아차관 & $\begin{array}{l}\text { 파키스탄 } 45 \text { 번 국 } \\
\text { 도(캘카탁-치트 랄) } \\
\text { 개선·확장사업 }\end{array}$ & 프로젝트 & $1,074.38$ & 130.07 & 계속 & $2017 \sim 2021$ & 양자유상 & 9 \\
\hline 53 & 아시아차관 & \begin{tabular}{|l|} 
파키스탄 IT 파크 \\
건립사업
\end{tabular} & 프로젝트 & 873.93 & 182.27 & 신규 & $2017 \sim 2021$ & 양자유상 & 9 \\
\hline 54 & 아프리카차관 & \begin{tabular}{|l|} 
가 나 \\
Prestea-Kumasi \\
전력 강화 사업
\end{tabular} & 프로젝트 & 752.82 & 10.12 & 계속 & $2015 \sim 2018$ & 양자유상 & 7 \\
\hline 55 & 아프리카차관 & $\begin{array}{l}\text { 르완다 국립 대학교 } \\
\text { 건립사업 }\end{array}$ & 프로젝트 & 587.12 & 171.24 & 계속 & $2015 \sim 2020$ & 양자유상 & 4 \\
\hline 56 & 아프리카차관 & \begin{tabular}{|ll} 
모잠비크 & 마푸토 \\
위생매립장 건립사 \\
업
\end{tabular} & 프로젝트 & 557.02 & 96.72 & 계속 & $2015 \sim 2020$ & 양자유상 & 6 \\
\hline 57 & 아프리카차관 & $\begin{array}{l}\text { 모잠비크 남풀라- } \\
\text { 나메틸론도로설 } \\
\text { 사업 }\end{array}$ & 프로젝트 & 864.28 & 169.58 & 계속 & $2015 \sim 2021$ & 양자유상 & 9 \\
\hline 58 & 아프리카차관 & $\begin{array}{l}\text { 모잠비크 공공안전 } \\
\text { 관리 정보화시스템 } \\
\text { 구축사업 }\end{array}$ & 프로젝트 & $1,016.24$ & 102.18 & 계속 & $2017 \sim 2021$ & 양자유상 & 9 \\
\hline 59 & 아프리카차관 & $\begin{array}{l}\text { 세네갈 해상인프라 } \\
\text { 구축사업 2차 }\end{array}$ & 프로젝트 & $1,017.82$ & 159.48 & 계속 & $2016 \sim 2019$ & 양자유상 & 9 \\
\hline
\end{tabular}




\begin{tabular}{|c|c|c|c|c|c|c|c|c|c|}
\hline & 세부사업명 & 내역사업명 & 사업 유형 & $\begin{array}{l}\text { 총사업 예산 } \\
\text { (억원) }\end{array}$ & $\begin{array}{l}\text { 18년예산 } \\
\text { (억원) }\end{array}$ & $\begin{array}{l}\text { 신규/ } \\
\text { 계속 }\end{array}$ & $\begin{array}{l}\text { 총사업 } \\
\text { 기간 }\end{array}$ & $\begin{array}{c}\text { 구분 } \\
\text { (양-다자) }\end{array}$ & $\begin{array}{l}\text { SDGs } \\
\text { 목표 }\end{array}$ \\
\hline 60 & 아프리카차관 & $\begin{array}{l}\text { 시에 라리온 프리타 } \\
\text { 운시 복합행정센터 } \\
\text { 건립사업 }\end{array}$ & 프로젝트 & 630.92 & 152.95 & 계속 & $2014 \sim 2019$ & 양자유상 & 9 \\
\hline 61 & 아프리카차관 & \begin{tabular}{|l|l|} 
에티오피아 고레- \\
테피 도로 개선사 \\
업
\end{tabular} & 프로젝트 & $1,458.92$ & 258.44 & 신규 & $2017 \sim 2023$ & 양자유상 & 9 \\
\hline 62 & 아프리카차관 & \begin{tabular}{|l} 
잠비아 공공안전정 \\
보화 시스템 ${ }^{\prime}$ 수국
\end{tabular} & 프로젝트 & 475.81 & 46.88 & 계속 & $2017 \sim 2019$ & 양자유상 & 16 \\
\hline 63 & 아프리카차관 & $\begin{array}{l}\text { 카메룬 가루아 종 } \\
\text { 합병원 건립사업 }\end{array}$ & 프로젝트 & 658.25 & 64.96 & 계속 & $2015 \sim 2019$ & 양자유상 & 3 \\
\hline 64 & 아프리카차관 & 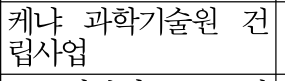 & 프로젝트 & $1,084.89$ & 132.78 & 신규 & $2017 \sim 2023$ & 양자유상 & 4 \\
\hline 65 & 아프리카차관 & \begin{tabular}{|l|} 
코트디부아르 국립 \\
암센터 건립사업 \\
\end{tabular} & 프로젝트 & $1,264.31$ & 124.51 & 계속 & $2017 \sim 2020$ & 양자유상 & 3 \\
\hline 66 & 아프리카차관 & $\begin{array}{|ll|}\text { 콩고민주공화국 } & \text { 렘 } \\
\text { 바ㅇㅣㅣㅂㅜ 상수도 } & \text { 사 } \\
\text { 업 } & \end{array}$ & 프로젝트 & 778.05 & 84.27 & 계속 & $2014 \sim 2022$ & 양자유상 & 6 \\
\hline 67 & 아프리카차관 & \begin{tabular}{|l|} 
탄자니아 잔지바르 \\
관개시설 개선사업
\end{tabular} & 프로젝트 & 572.82 & 63.18 & 계속 & $2014 \sim 2022$ & 양자유상 & 2 \\
\hline 68 & 아프리카차관 & $\begin{array}{ll}\text { 탄자니아 } & \text { 주민증 } \\
\text { 뎅이터센터 } & \text { 건립사 } \\
\text { 업 }\end{array}$ & 프로젝트 & 586.50 & 2.53 & 계속 & $2014 \sim 2019$ & 양자유상 & 9 \\
\hline 69 & 아프리카차관 & $\begin{array}{l}\text { 탄자니아 샐린더 } \\
\text { 교량 건설사업 }\end{array}$ & 프로젝트 & $1,042.90$ & 98.53 & 계속 & $2016 \sim 2021$ & 양자유상 & 9 \\
\hline 70 & 아프리카차관 & $\begin{array}{l}\text { 탄자니아 다레살람 } \\
\text { 시하수처리시설 } \\
\text { 구축사업 }\end{array}$ & 프로젝트 & $1,032.13$ & 150.24 & 신규 & $2017 \sim 2023$ & 양자유상 & 6 \\
\hline 71 & 중동-CIS차관 & $\begin{array}{l}\text { 아제르바이잔 피르 } \\
\text { 샤기 하수처리장 } \\
\text { 건립사업 }\end{array}$ & 프로젝트 & 530.29 & 210.87 & 계속 & $2015 \sim 2020$ & 양자유상 & 6 \\
\hline 72 & 중동-CIS차관 & $\begin{array}{l}\text { 아제르바이잔 직업 } \\
\text { 훈련 센터 건립사업 }\end{array}$ & 프로젝트 & 252.04 & 94.10 & 계속 & $2015 \sim 2020$ & 양자유상 & 4 \\
\hline 73 & 중동-CIS차관 & $\begin{array}{l}\text { 요르단 나우르 폐 } \\
\text { 수처리사업(보충융 } \\
\text { 자) }\end{array}$ & 프로젝트 & 343.69 & 146.64 & 계속 & $2017 \sim 2019$ & 양자유상 & 6 \\
\hline 74 & 중동-CIS차관 & 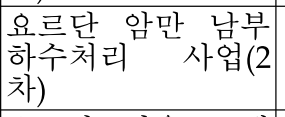 & 프로젝트 & 487.56 & 34.51 & 계속 & $2011 \sim 2018$ & 양자유상 & 6 \\
\hline 75 & 중동-CIS차관 & $\begin{array}{l}\text { 요르단 나우르 폐 } \\
\text { 수처리사업 }\end{array}$ & 프로젝트 & 238.29 & 145.84 & 계속 & $2008 \sim 2019$ & 양자유상 & 6 \\
\hline 76 & 중동-CIS차관 & $\begin{array}{l}\text { 우즈베키스탄ㄴ전전잔 } \\
\text { 정부통합데이터센 } \\
\text { 터 구축사업 }\end{array}$ & 프로젝트 & 309.32 & 116.36 & 계속 & $2017 \sim 2019$ & 양자유상 & 9 \\
\hline 77 & 중동-CIS차관 & $\begin{array}{l}\text { 우즈베키스탄 교육 } \\
\text { 정보화 2차사업 }\end{array}$ & 프로젝트 & 378.06 & 186.55 & 계속 & $2017 \sim 2020$ & 양자유상 & 4 \\
\hline 78 & 중동-CIS차관 & $\begin{array}{l}\text { 우즈베키크스난 국립 } \\
\text { 전자도서관 구축사 } \\
\text { 업 }\end{array}$ & 프로젝트 & 164.41 & 75.45 & 계속 & $2015 \sim 2018$ & 양자유상 & 4 \\
\hline 79 & 중동-CIS차관 & $\begin{array}{l}\text { 우즙베키스탄 국립 } \\
\text { 아동병원 건립사업 }\end{array}$ & 프로젝트 & $1,178.24$ & 572.26 & 계속 & $2015 \sim 2019$ & 양자유상 & 3 \\
\hline 80 & 중동-CIS차관 & $\begin{array}{l}\text { 우즙베키스탄 국가 } \\
\text { 지리정보시트템 } \\
\text { 축사업 }\end{array}$ & 프로젝트 & 174.87 & 67.09 & 계속 & $2015 \sim 2020$ & 양자유상 & 9 \\
\hline 81 & 중동-CIS차관 & $\begin{array}{l}\text { 우즈베키스탄 타슈 } \\
\text { 켄트 국제공항 신 } \\
\text { 여객ㄱ터미널 건설사 } \\
\text { 업 }\end{array}$ & 프로젝트 & $2,291.28$ & 486.81 & 신규 & $2017 \sim 2020$ & 양자유상 & 9 \\
\hline 82 & 중남미차관 & $\begin{array}{l}\text { 니카라과 지방 태 } \\
\text { 양광에너지 공급사 } \\
\text { 업 }\end{array}$ & 프로젝트 & 382.41 & 91.63 & 계속 & $2017 \sim 2020$ & 양자유상 & 7 \\
\hline 83 & 중남미차관 & $\begin{array}{l}\text { 니카라과 후이갈파 } \\
\text { 하수처리사업 }\end{array}$ & 프로젝트 & 760.11 & 121.47 & 계속 & $2016 \sim 2019$ & 양자유상 & 6 \\
\hline 84 & 중남미차관 & $\begin{array}{l}\text { 니카라과 마나과 } \\
\text { 우회도로 건설사업 }\end{array}$ & 프로젝트 & 808.71 & 122.79 & 신규 & $2017 \sim 2022$ & 양자유상 & 9 \\
\hline 85 & 중남미차관 & \begin{tabular}{|l|} 
도미니카공화국 출 \\
입국 관리시스템 \\
구축사업
\end{tabular} & 프로젝트 & 279.77 & 13.05 & 계속 & $2013 \sim 2019$ & 양자유상 & 9 \\
\hline
\end{tabular}




\begin{tabular}{|c|c|c|c|c|c|c|c|c|c|}
\hline & 세부사업명 & 내역사업명 & 사업 유형 & $\begin{array}{l}\text { 총사업 예산 } \\
\text { (억원) }\end{array}$ & $\begin{array}{l}\text { '18년 예산 } \\
\text { (억원) }\end{array}$ & \begin{tabular}{|l|} 
신규/ \\
계속
\end{tabular} & $\begin{array}{l}\text { 총사업 } \\
\text { 기간 }\end{array}$ & \begin{tabular}{|c|} 
구분 \\
(양-다자)
\end{tabular} & $\begin{array}{l}\text { SDGs } \\
\text { 목표 }\end{array}$ \\
\hline 86 & 중남미차관 & $\begin{array}{l}\text { 에콰도르 산토도밍 } \\
\text { 고시 하수도 확장 } \\
\text { 사업 }\end{array}$ & 프로젝트 & 778.77 & 93.00 & 계속 & $2015 \sim 2019$ & 양자유상 & 6 \\
\hline 87 & 중남미차관 & $\begin{array}{l}\text { 온두라스 농촌 태 } \\
\text { 양광 전력화사업 }\end{array}$ & 프로젝트 & 511.98 & 83.21 & 계속 & $2015 \sim 2019$ & 양자유상 & 7 \\
\hline 88 & 중남미차관 & $\begin{array}{l}\text { 온두라스 촐루테카 } \\
\text { 병원 건립사업 }\end{array}$ & 프로젝트 & 378.31 & 71.37 & 계속 & $2012 \sim 2019$ & 양자유상 & 3 \\
\hline 89 & $\begin{array}{l}\text { 태평양(대양주포함)차 } \\
\text { 관 }\end{array}$ & $\begin{array}{l}\text { 인도네시아 경찰청 } \\
\text { 고속순시선 공급사 } \\
\text { 업 }\end{array}$ & 프로젝트 & 409.30 & 82.67 & 계속 & $2015 \sim 2018$ & 양자유상 & 16 \\
\hline 90 & $\begin{array}{l}\text { 태평양(대양주포함)차 } \\
\text { 관 }\end{array}$ & $\begin{array}{l}\text { 인도네시아 바탐 } \\
\text { 하수처리시설 구축 } \\
\text { 사업 }\end{array}$ & 프로젝트 & 573.97 & 65.79 & 계속 & $2015 \sim 2019$ & 양자유상 & 6 \\
\hline 91 & $\begin{array}{l}\text { 태평양(대양주포함)차 } \\
\text { 관 }\end{array}$ & $\begin{array}{l}\text { 인도네시아 카리안 } \\
\text { 댐 건설사업 }\end{array}$ & 프로젝트 & $1,095.20$ & 101.23 & 계속 & $2013 \sim 2019$ & 양자유상 & 6 \\
\hline 92 & $\begin{array}{l}\text { 태평양(대양주포함)차 } \\
\text { 관 }\end{array}$ & $\begin{array}{l}\text { 인도네시아 경찰청 } \\
\text { 무선통신망 구축사 } \\
\text { 업 }\end{array}$ & 프로젝트 & 458.21 & 55.67 & 계속 & $2014 \sim 2020$ & 양자유상 & 16 \\
\hline 93 & $\begin{array}{l}\text { 태평양(대양주포함)차 } \\
\text { 관 }\end{array}$ & $\begin{array}{l}\text { 인도네시아 수자원 } \\
\text { 엔지니어링 사업 }\end{array}$ & 프로젝트 & 363.23 & 4.21 & 신규 & $2017 \sim 2020$ & 양자유상 & 6 \\
\hline 94 & $\begin{array}{l}\text { 태평양(대양주포함)차 } \\
\text { 관 }\end{array}$ & $\begin{array}{l}\text { 필리핀팡일만 교 } \\
\text { 량 건설사업 }\end{array}$ & 프로젝트 & $1,147.15$ & 189.61 & 계속 & $2017 \sim 2020$ & 양자유상 & 9 \\
\hline 95 & $\begin{array}{l}\text { 태평양(대양주포함)차 } \\
\text { 관 }\end{array}$ & $\begin{array}{l}\text { 필리핀 팜팡가지옃 } \\
\text { 통합재난위험감축 } \\
\text { 및기후변화 적응 } \\
\text { 사업 }\end{array}$ & 프로젝트 & 922.05 & 104.60 & 계속 & $2016 \sim 2021$ & 양자유상 & 2 \\
\hline 96 & $\begin{array}{l}\text { 태평양(대양주포함)차 } \\
\text { 관 }\end{array}$ & $\begin{array}{ll}\text { 필리핀 } & \text { 할라우강 } \\
\text { 다목적 } & \text { 사업(2단 } \\
\text { 계) } & \\
\end{array}$ & 프로젝트 & $2,381.56$ & 254.77 & 계속 & $2013 \sim 2022$ & 양자유상 & 2 \\
\hline 97 & $\begin{array}{l}\text { 태평양(대양주포함)차 } \\
\text { 관 }\end{array}$ & $\begin{array}{l}\text { 필리핀 사마르 해 } \\
\text { 안도로 사업 }\end{array}$ & 프로젝트 & 236.36 & 42.60 & 계속 & $2016 \sim 2019$ & 양자유상 & 9 \\
\hline 98 & 민간·국제기구협력차관 & $\begin{array}{l}\text { 니카라과 재생에너 } \\
\text { 지 송변전사업(2 } \\
\text { 차) }\end{array}$ & 프로젝트 & 552.30 & 112.26 & 계속 & $2015 \sim 2019$ & 양자유상 & 7 \\
\hline 99 & 민간·국제기구협력차관 & $\begin{array}{l}\text { 니카라과 브로드밴 } \\
\text { 드 구축사업 }\end{array}$ & 프로젝트 & 286.41 & 140.84 & 계속 & $2016 \sim 2020$ & 양자유상 & 9 \\
\hline 100 & 민간·국제기구협력차관 & $\begin{array}{l}\text { 니카라과 지열발전 } \\
\text { 탐사 및 송전망 확 } \\
\text { 충지원 사업 }\end{array}$ & 프로젝트 & 286.41 & 36.45 & 신규 & $2017 \sim 2021$ & 양자유상 & 7 \\
\hline 101 & 민간·국제기구협력차관 & $\begin{array}{l}\text { 라오스 세피안 세 } \\
\text { 남노이 수력발전사 } \\
\text { 업 }\end{array}$ & 프로젝트 & 925.68 & 126.11 & 계속 & $2015 \sim 2019$ & 양자유상 & 7 \\
\hline 102 & 민간·국제기구협력차관 & $\begin{array}{l}\text { 라오스 GMS 북부 } \\
\text { 송전사업 }\end{array}$ & 프로젝트 & 436.08 & 59.03 & 계속 & $2012 \sim 2018$ & 양자유상 & 7 \\
\hline 103 & 민간·국제기구협력차관 & $\begin{array}{l}\text { 라오슬 참파삭주 } \\
\text { 메콩강변 관리 } \\
\text { 사업 }\end{array}$ & 프로젝트 & 607.85 & 81.61 & 계속 & $2016 \sim 2022$ & 양자유상 & 2 \\
\hline & 민간·국제기구협력차관 & 말리 관개개발사업 & 프로젝트 & 262.40 & 19.13 & 계속 & $2016 \sim 2018$ & 양자유상 & 2 \\
\hline 105 & 3민간·국제기구협력차관 & $\begin{array}{l}\text { 모잠비크 나칼라 } \\
\text { 연결도로 개보수 } 1 \\
\text { 차 사업 }\end{array}$ & 프로젝트 & 229.13 & 29.10 & 계속 & $2011 \sim 2018$ & 양자유상 & 9 \\
\hline 106 & 민간·국제기구협력차관 & \begin{tabular}{|lr} 
미얀마 & $500 \mathrm{kV}$ \\
Taungoo- & Kamanat \\
송전망 & 구축사업 \\
\end{tabular} & 프로젝트 & $1,145.64$ & 167.28 & 계속 & $2017 \sim 2021$ & 양자유상 & 7 \\
\hline 107 & 민간·국제기구협력차관 & $\begin{array}{l}\text { 방글라데시 철도신 } \\
\text { 홋시스템 현대화 } \\
\text { 사업 }\end{array}$ & 프로젝트 & 252.08 & 42.51 & 계속 & $2013 \sim 2019$ & 양자유상 & 9 \\
\hline 108 & 민간·국제기구협력차관 & $\begin{array}{l}\text { 방글라데시 철도차 } \\
\text { 량 (객차) 구매사 } \\
\text { 업 }\end{array}$ & 프로젝트 & $1,157.10$ & 206.74 & 계속 & $2017 \sim 2019$ & 양자유상 & 9 \\
\hline 109 & 민간·국제기구협력차관 & $\begin{array}{l}\text { 방글라데시 ICT 교 } \\
\text { 육훈련 센터 건립 } \\
\text { 사업(2차) }\end{array}$ & 프로젝트 & 870.94 & 10.45 & 신규 & $2017 \sim 2020$ & 양자유상 & 4 \\
\hline & 민간·국제기구협력차관 & $\begin{array}{l}\begin{array}{l}\text { 베트남 훙옌시 폐 } \\
\text { 수처리 시설 건설 } \\
\text { 사업 }\end{array} \\
\end{array}$ & 프로젝트 & 271.73 & 37.34 & 계속 & $2014 \sim 2019$ & 양자유상 & 6 \\
\hline
\end{tabular}




\begin{tabular}{|c|c|c|c|c|c|c|c|c|c|}
\hline & 세부사업명 & 내역사업명 & 사업 유형 & $\begin{array}{c}\text { 총사업예산 } \\
\text { (억원) }\end{array}$ & $\begin{array}{c}18 \text { 년예산 } \\
\text { (억원) }\end{array}$ & $\begin{array}{l}\text { 신규/ } \\
\text { 계속 }\end{array}$ & $\begin{array}{l}\text { 총사업 } \\
\text { 기간 }\end{array}$ & $\begin{array}{c}\text { 구분 } \\
\text { (양-다자) }\end{array}$ & $\begin{array}{l}\text { SDGS } \\
\text { 목표 }\end{array}$ \\
\hline 111 만 & 민간·국제기구협력차관 & 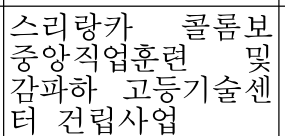 & 프로젝트 & 290.06 & 43.44 & 계속 & $2014 \sim 2018$ & 양자유상 & 4 \\
\hline 112 만 & 민간·국제기구협력차관 & $\begin{array}{l}\text { 에티오피아 모조- } \\
\text { 하와사 고속도로 } \\
\text { 건설사업 }\end{array}$ & 프로젝트 & $1,197.44$ & 172.56 & 계속 & $2016 \sim 2019$ & 양자유상 & 9 \\
\hline 113 문 & 민간·국제기구협력차관 & $\begin{array}{l}\text { 이집트 철도 전자 } \\
\text { 연동시스템 구축사 } \\
\text { 업 }\end{array}$ & 프로젝트 & $1,317.23$ & 256.70 & 계속 & $2017 \sim 2020$ & 양자유상 & 9 \\
\hline 114 문 & 민간·국제기구협력차관 & $\begin{array}{l}\text { 캄보디아 지방도로 } \\
\text { 개선사업 2차 }\end{array}$ & 프로젝트 & 485.31 & 76.51 & 계속 & $2015 \sim 2019$ & 양자유상 & 9 \\
\hline 115 & 국제금융기구 출연 & $\begin{array}{l}\text { WB 빈곤감축사회개 } \\
\text { 발기금 }\end{array}$ & 분담금 & 207 & 92 & 계속 & '17 ’19 & 다자 & \\
\hline 116 & 국제금융기구 출연 & WB 녹색성장기금 & 분담금 & 552 & 138 & 계속 & '16 '19 & 다자 & \\
\hline 117 & 국제금융기구 출연 & $\begin{array}{l}\text { WB 초급전문가 파 } \\
\text { 견 }\end{array}$ & 분담금 & 23 & 23 & 계속 & ‘18 & 다자 & \\
\hline 118 & 국제금융기구 출연 & $\begin{array}{l}\text { WB 한-WB 협력기 } \\
\text { 금 }\end{array}$ & 분담금 & 1,035 & 368 & 계속 & ‘16 ’18 & 다자 & \\
\hline 119 & 국제금융기구 출연 & $\begin{array}{l}\text { WB 경제평화구축기 } \\
\text { 금 }\end{array}$ & 분담금 & 173 & 57.5 & 계속 & ‘17 '19 & 다자 & \\
\hline 120 & 국제금융기구 출연 & IFC 기술협력기금 & 분담금 & 173 & 57.5 & 신규 & '18 '20 & 다자 & \\
\hline 121 & 국제금융기구 출연 & $\begin{array}{l}\mathrm{ADB} \text { e-Asia 지식 } \\
\text { 협력기금 }\end{array}$ & 분담금 & 219 & 219 & 계속 & ‘18 & 다자 & \\
\hline 122 & 국제금융기구 출연 & $\begin{array}{l}\mathrm{AfDB} \text { 한아프리카 } \\
\text { 협력기금 }\end{array}$ & 분담금 & 242 & 138 & 계속 & '17 ’18 & 다자 & \\
\hline 123 & 국제금융기구 출연 & $\begin{array}{l}\text { EBRD 기술자문협력 } \\
\text { 기금 }\end{array}$ & 분담금 & 34.5 & 34.5 & 계속 & ‘18 & 다자 & \\
\hline 124 & 국제금융기구 출연 & $\begin{array}{l}\text { EBRD 체제지원국지 } \\
\text { 원기금 }\end{array}$ & 분담금 & 11.5 & 11.5 & 계속 & ‘18 & 다자 & \\
\hline 125 & 국제금융기구 출연 & $\begin{array}{l}\text { IDB 재정혁신협력기 } \\
\text { 금 }\end{array}$ & 분담금 & 49 & 49 & 계속 & ‘18 & 다자 & \\
\hline 126 & 국제금융기구 출연 & IDB 빈곤감축기금 & 분담금 & 46 & 46 & 신규 & ‘18 & 다자 & \\
\hline 127 & 국제금융기구 출연 & $\begin{array}{l}\text { IMF한-IMF 기술협 } \\
\text { 력기금 }\end{array}$ & 분담금 & 173 & 35 & 계속 & $' 18 \sim 21$ & 다자 & \\
\hline 128 & 녹색가후기금 운영 지원 & $\begin{array}{l}\text { 녹색기후기금 운영 } \\
\text { 지원 }\end{array}$ & 분담금 & 1,150 & 126.5 & 계속 & '12 계속 & 다자 & \\
\hline 129 & 국제금융기구 출연 & $\begin{array}{l}\text { 한-CABEI 협력기금 } \\
\text { (가칭) }\end{array}$ & 분담금 & 34.5 & 34.5 & 신규 & ‘18 & 다자 & \\
\hline $130 \pi$ & $\begin{array}{l}\text { 메콩강위원회와의 경 } \\
\text { 제발전경험공유사업 } \\
\text { (KSP) }\end{array}$ & $\begin{array}{l}\text { 메콩강 유역 환경자원 } \\
\text { 관리 전략 }\end{array}$ & 개발컨설팅 & 4.50 & 4.50 & 신규 & $2018-2019$ & 양자무상 & 6 \\
\hline 131 & $\begin{array}{l}\text { 미얀마와의 경제발전 } \\
\text { 경험공유사업 }(\mathrm{KSP})\end{array}$ & $\begin{array}{l}\text { 미얀마 중앙통계청의 } \\
\text { 연구 및 역량 개발 } \\
\text { 방안 }\end{array}$ & 개발컨설팅 & 3.50 & 3.50 & 신규 & $18.5 \sim ' 19.8$ & 양자무상 & 17 \\
\hline $132^{\prime \prime}$ & $\begin{array}{l}\text { 베트남과의 경제발전 } \\
\text { 경험공유사업(KSP) }\end{array}$ & $\begin{array}{l}\text { WTO와 FTA체제에 } \\
\text { 서의 무역기술장벽 } \\
\text { 대응방안 }\end{array}$ & 개발컨설팅 & 3.20 & 3.20 & 신규 & $2018-2019$ & 양자무상 & 8 \\
\hline 133 & $\begin{array}{l}\text { 스리랑카와의 경제발 } \\
\text { 전경험공유사업(KSP) }\end{array}$ & \begin{tabular}{|l|} 
스리랑카 저소득측대 \\
상 주택 및 주거환경 \\
프로그램 개선을 위한 \\
역량강화 방안
\end{tabular} & 개발컨설팅 & 3.20 & 3.20 & 신규 & $18.5 \sim ' 19.8$ & 양자무상 & 11 \\
\hline 134 & $\begin{array}{l}\text { 과테말라와의 } \begin{array}{l}\text { 경제발 } \\
\text { 전경험공유사업 }(\mathrm{KSP})\end{array}\end{array}$ & $\begin{array}{l}\text { 재무행정의 자동화 및 } \\
\text { 디지털화 제고 }\end{array}$ & 개발컨설팅 & 3.80 & 3.80 & 신규 & $18.5 \sim ' 19.8$ & 양자무상 & 16 \\
\hline 135 & $\begin{array}{l}\text { 과테말라와의 } \begin{array}{r}\text { 경제발 } \\
\text { 전경험공유사업 }(\mathrm{KSP})\end{array}\end{array}$ & $\begin{array}{l}\text { 정부투명성 증진 및 } \\
\text { 상시 평가체계 구축 }\end{array}$ & 개발컨설팅 & 3.80 & 3.80 & 신규 & $18.5 \sim ' 19.8$ & 양자무상 & 16 \\
\hline 136 & $\begin{array}{l}\text { 멕시코와의 경제발전 } \\
\text { 경험공유사업(KSP) }\end{array}$ & $\begin{array}{l}\text { 과학기술·산업분석을 } \\
\text { 통한혁신정책수립지원 } \\
\text { 2단계 }\end{array}$ & 개발컨설팅 & 3.80 & 3.80 & 신규 & $18.5 \sim ' 19.8$ & 양자무상 & 9 \\
\hline 137 & $\begin{array}{l}\text { 온두라스와의 경제발 } \\
\text { 전경험공유사업(KSP) }\end{array}$ & $\begin{array}{l}\text { 온두라스 신용보증시 } \\
\text { 스템 관리감독기능 } \\
\text { 발전 강화 }\end{array}$ & 개발컨설팅 & 3.80 & 3.80 & 신규 & $18.5 \sim ' 19.8$ & 양자무상 & 9 \\
\hline
\end{tabular}




\begin{tabular}{|c|c|c|c|c|c|c|c|c|}
\hline 세부사업명 & 내역사업명 & 사업 유형 & $\begin{array}{c}\text { 총사업 예산 } \\
\text { (억원) }\end{array}$ & $\begin{array}{l}\text { '18년예산 } \\
\text { (억원) }\end{array}$ & $\begin{array}{l}\text { 신규/ } \\
\text { 계속 }\end{array}$ & $\begin{array}{l}\text { 총사업 } \\
\text { 기간 }\end{array}$ & \begin{tabular}{|c|} 
구분 \\
(양-다자)
\end{tabular} & $\begin{array}{l}\text { SDGs } \\
\text { 목표 }\end{array}$ \\
\hline $\begin{array}{l}138 \text { 쿠바와의 경제발전경 } \\
\text { 험 공유사업(KSP) }\end{array}$ & \begin{tabular}{|l|} 
쿠바 산업화 발전방안 \\
II
\end{tabular} & 개발컨설팅 & 4.20 & 4.20 & 신규 & $18.5 \sim 19.8$ & 양자무상 & 9 \\
\hline 139 페루와의 경제발전경 & \begin{tabular}{|l|} 
중소기업 지원을 위한 \\
기술 보증 및 승인 \\
방안
\end{tabular} & 개발컨설팅 & 3.80 & 3.80 & 신규 & $18.5 \sim ' 19.8$ & 양자무상 & 9 \\
\hline $\begin{array}{l}140 \text { 페루와의 경제발전경 } \\
\text { 험 공유사업(KSP) }\end{array}$ & $\begin{array}{l}\mathrm{PPP} \text { 를 통한 국가 인 } \\
\text { 프라 분야 발전 방안 }\end{array}$ & 개발컨설팅 & 3.80 & 3.80 & 신규 & $18.5 \sim 19.8$ & 양자무상 & 9 \\
\hline $\begin{array}{l}141 \text { 몽골과의 경제발전경 } \\
\text { 험공유사업(KSP) }\end{array}$ & $\begin{array}{l}\text { 거시경제정책 결정자 } \\
\text { 역량강화 사업 }\end{array}$ & 개발컨설팅 & 3.00 & 3.00 & 신규 & $18.5 \sim ' 19.8$ & 양자무상 & 8 \\
\hline $\begin{array}{l}\text { 우크라이나와의 경제 } \\
142 \text { 발전경험공유사업 } \\
\text { (KSP) }\end{array}$ & $\begin{array}{l}\text { 국내외 투자 활성화를 } \\
\text { 위한 매커니즘 및 구 } \\
\text { 체적 수단 수립 방안 }\end{array}$ & 개발컨설팅 & 4.00 & 4.00 & 신규 & $2018-2019$ & 양자무상 & 8 \\
\hline $\begin{array}{l}\text { 카자흐스탄과의 경제 } \\
143 \text { 발전경험공유사업 } \\
\text { (KSP) }\end{array}$ & $\begin{array}{l}\mathrm{PPP} \text { 프로젝트 개발 } \\
\text { 및 실행 }\end{array}$ & 개발컨설팅 & 3.20 & 3.20 & 신규 & $2018-2019$ & 양자무상 & 9 \\
\hline $\begin{array}{l}\text { 키르기즈공화국과의 } \\
144 \text { 경제발전경험공유사업 } \\
\text { (KSP) }\end{array}$ & $\begin{array}{l}\text { 공공 인적자원관리 효 } \\
\text { 율성 제고: 공무원 } \\
\text { 선발제도를 중심으로 }\end{array}$ & 개발컨설팅 & 3.00 & 3.00 & 신규 & $2018-2019$ & 양자무상 & 8 \\
\hline $\begin{array}{l}\text { 에티오피아와의 경제 } \\
145 \text { 발전경험공유사업 } \\
\text { (KSP) }\end{array}$ & $\begin{array}{l}\text { 주택건설 및 공공주택 } \\
\text { 행정 향상 }\end{array}$ & 개발컨설팅 & 3.40 & 3.40 & 신규 & $18.5 \sim 19.8$ & 양자무상 & 11 \\
\hline 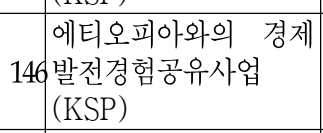 & $\begin{array}{l}\text { 지속가능한 성장을 위 } \\
\text { 한 금응 접근성 제고 } \\
\text { 정책 }\end{array}$ & 개발컨설팅 & 3.40 & 3.40 & 신규 & $18.5 \sim 19.8$ & 양자무상 & 8 \\
\hline $\begin{array}{l}147 \text { 베트남과의 경제발전 } \\
\text { 경험공유사업(KSP) }\end{array}$ & $\begin{array}{l}\text { 베트남 폐수처리시스 } \\
\text { 템 도입 가능 여부에 } \\
\text { 대한 타당성조사 }\end{array}$ & 개발컨설팅 & 3.20 & 3.20 & 신규 & $2018-2019$ & 양자무상 & 6 \\
\hline 148 탄자니아와의 경제발 & $\begin{array}{l}\text { 탄자니아 e-Gov. 연 } \\
\text { 구개발 역량강화 지 } \\
\text { 원 }\end{array}$ & 개발컨설팅 & 3.50 & 3.50 & 신규 & $18.5 \sim ' 19.8$ & 양자무상 & 17 \\
\hline 1499 공동컨설팅 & \begin{tabular}{|l|}
$\mathrm{KSP}-\mathrm{WB}$ 페루건강보 \\
험제도개선지원
\end{tabular} & 개발컨설팅 & 3.30 & 3.30 & 신규 & $18.5 \sim ' 19.8$ & 다자성양자 & 3 \\
\hline 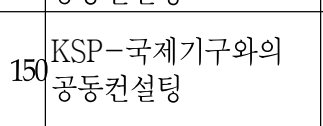 & $\begin{array}{l}\mathrm{KSP}-\mathrm{ADB} \text { 키르키즈통 } \\
\text { 합수자원관리제도구축 } \\
\text { 을위한ICT지원 }\end{array}$ & 개발컨설팅 & 3.50 & 3.50 & 신규 & $18.5 \sim ' 19.8$ & 다자성양자 & 6 \\
\hline 151 공동컨설팅 & $\begin{array}{l}\text { KSP-ADB베트남기술 } \\
\text { 이전을통한기업역량강 } \\
\text { 화지원 }\end{array}$ & 개발컨설팅 & 3.50 & 3.50 & 신규 & $18.5 \sim ' 19.8$ & 다자성양자 & 8 \\
\hline $\begin{array}{l}152 \text { KSP-국제기구와의 } \\
\text { 공콩컨설팅 }\end{array}$ & $\begin{array}{l}\mathrm{KSP}-\mathrm{ADB} \text { 스리랑카기 } \\
\text { 술교육대학지원을위한 } \\
\text { 기본계획수립 }\end{array}$ & 개발컨설팅 & 3.50 & 3.50 & 신규 & $18.5 \sim ' 19.8$ & 다자성양자 & 4 \\
\hline 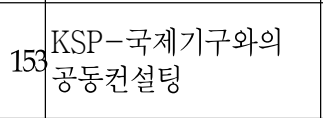 & $\begin{array}{l}\mathrm{KSP}-\mathrm{ADB} \text { 인도동부해 } \\
\text { 안경제권개발을위한기 } \\
\text { 본계획수립 }\end{array}$ & 개발컨설팅 & 3.50 & 3.50 & 신규 & $18.5 \sim ' 19.8$ & 다자성양자 & 11 \\
\hline 154 KSP-국제기구와의 & $\begin{array}{l}\mathrm{KSP}-\mathrm{ADB} \text { 보편적 의 } \\
\text { 료보장 달성을 위한 } \\
\text { 계획수립 지원 }\end{array}$ & 개발컨설팅 & 3.70 & 3.70 & 신규 & $18.5 \sim 19.8$ & 다자성양자 & 3 \\
\hline 155 KSP-공동제ㄱㅓㅓ설티깅 & $\begin{array}{l}\text { KSP-EBRD 우크라 } \\
\text { 이나 우체국 현대화 } \\
\text { 사업 지원 }\end{array}$ & 개발컨설팅 & 5.70 & 5.70 & 신규 & $18.5 \sim ' 19.8$ & 다자성양자 & 17 \\
\hline${ }_{156} \mathrm{KSP}$ 공동컨설젤팅 & $\begin{array}{l}\text { KSP-IDB 온두라스 } \\
\text { 국가 침해사고대응센 } \\
\text { 터 설립 지원 }\end{array}$ & 개발컨설팅 & 4.00 & 4.00 & 신규 & $18.5 \sim ' 19.8$ & 다자성양자 & 11 \\
\hline 157 공동컨설팅 & $\begin{array}{l}\text { KSP-IDB 에콰도르 } \\
\text { 국가교통 마스터플랜 } \\
\text { 수립 }\end{array}$ & 개발컨설팅 & 4.00 & 4.00 & 신규 & $18.5 \sim ' 19.8$ & 다자성양자 & 11 \\
\hline 158 KSP-궁젱동컨설팅 & $\begin{array}{l}\text { 페루 통합 물관리시스 } \\
\text { 템 구축을 위한 사전 } \\
\text { 타당성 조사 }\end{array}$ & 개발컨설팅 & 3.50 & 3.50 & 신규 & $18.5 \sim ' 19.8$ & 다자성양자 & 6 \\
\hline 159 공동컨설텅 & $\begin{array}{l}\text { KSP-IDB 페루 지능 } \\
\text { 형 교통관리 시스템 } \\
\text { (ITS) 수립을 위한 } \\
\text { 세부 실행계획수립 }\end{array}$ & 개발컨설팅 & 3.50 & 3.50 & 신규 & $18.5 \sim ' 19.8$ & 다자성양자 & 11 \\
\hline
\end{tabular}




\begin{tabular}{|c|c|c|c|c|c|c|c|c|c|}
\hline & 세부사업명 & 내역사업명 & 사업 유형 & $\begin{array}{c}\begin{array}{c}\text { 총사업예산 } \\
\text { (억원) }\end{array} \\
\end{array}$ & $\begin{array}{l}18 \text { 년예산 } \\
\text { (억원) }\end{array}$ & \begin{tabular}{|l|} 
신규/ \\
계속
\end{tabular} & $\begin{array}{l}\text { 총사업 } \\
\text { 기간 }\end{array}$ & $\begin{array}{c}\text { 구분 } \\
\text { (양-다자) }\end{array}$ & $\begin{array}{l}\text { SDGs } \\
\text { 목표 }\end{array}$ \\
\hline 160 & $\begin{array}{l}\text { KSP-국제기구와의 } \\
\text { 공동컨설팅 }\end{array}$ & $\begin{array}{l}\text { KSP-IDB 도미니카 } \\
\text { (공) 농어촌/격오지 } \\
\text { 브로드밴드 구축 위한 } \\
\text { 공공.민간 파트너십 } \\
\text { 모델 설계 }\end{array}$ & 개발컨설팅 & 3.50 & 3.50 & 신규 & $18.5 \sim 19.8$ & 다자성양자 & 9 \\
\hline 161 & $\begin{array}{l}\mathrm{KSP}-\text { 국제기구와의 } \\
\text { 공동컨설팅 }\end{array}$ & $\begin{array}{l}\mathrm{KSP}-\mathrm{IDB} \text { 아르헨티 } \\
\text { 나 부에노스아이레스 } \\
\text { 시정부, 데이터 센터 } \\
\text { 구축 지원 }\end{array}$ & 개발컨설팅 & 3.00 & 3.00 & 신규 & $18.5 \sim ' 19.8$ & 다자성양자 & 17 \\
\hline 162 & $\begin{array}{l}\mathrm{KSP} \text {-국제기구와의 } \\
\text { 공동컨설팅 }\end{array}$ & $\begin{array}{l}\text { KSP-IDB 코스타리 } \\
\text { 카 기반 인프라 보안 } \\
\text { 을 위한 ‘국가 보안센 } \\
\text { 터' 구축 지원 }\end{array}$ & 개발컨설팅 & 4.00 & 4.00 & 신규 & $18.5 \sim 19.8$ & 다자성양자 & 11 \\
\hline 163 & $\begin{array}{l}\mathrm{KSP} \text {-국제기구와의 } \\
\text { 공동컨설팅 }\end{array}$ & $\begin{array}{l}\text { KSP-IDB 볼리비아 } \\
\text { 스마트 수자원 정보 } \\
\text { 관리 시스템 구축 }\end{array}$ & 개발컨설팅 & 4.00 & 4.00 & 신규 & $18.5 \sim ' 19.8$ & 다자성양자 & 6 \\
\hline & $\begin{array}{l}\text { 사업진행컨설팅 } \\
\text { (EDCF) }\end{array}$ & $\begin{array}{l}\text { 사업진행컨설팅 } \\
\text { (EDCF) }\end{array}$ & 프로젝트 & & 253.33 & 계속 & & 양자무상 & \\
\hline & $\begin{array}{l}\text { 경제협력기반구축 } \\
\text { (EDCF) }\end{array}$ & $\begin{array}{l}\text { 경제협력기반구축 } \\
\text { (EDCF) }\end{array}$ & 행정비용 & & 30.59 & 계속 & & 양자무상 & \\
\hline & 기금운영비(EDCF) & 기금운영비(EDCF) & 행정비용 & & 163.27 & 계속 & & 양자무상 & \\
\hline 167 & 관세협력기구 출연 & $\begin{array}{l}\text { WCO 개발도상국 관 } \\
\text { 세공무원 능력배양 } \\
\text { 사업지원 }\end{array}$ & 기타 & & 11.34 & 계속 & $\begin{array}{l}\text { 2012년 } \\
\text { 이후 계속 }\end{array}$ & 다자성양자 & 17 \\
\hline & 관세협력기구 출연 & $\begin{array}{l}\text { UNESCAP개발도상국 } \\
\text { 간무역협정(APTA) }{ }_{2} \text { 갈 } \\
\text { 전및개도국무역·투자 } \\
\text { 프로ㅈㅔㅔ트에대한협력기 } \\
\text { 금출연 }\end{array}$ & 기타 & & 2.44 & 계속 & $\begin{array}{l}\text { 2015년 } \\
\text { 이후 계속 }\end{array}$ & 다자성양자 & 17 \\
\hline
\end{tabular}




\section{교육부 2018년도 ODA 예산 계획[안]}

$\square$ 총괄

\begin{tabular}{l|c|c|c||c|c|c}
\hline \multirow{2}{*}{$\mathrm{ODA}$ 시행부처(기관) } & \multicolumn{3}{|c||}{2017} & \multicolumn{3}{c}{2018 (요구) } \\
\cline { 2 - 7 } & 양자 무상 & 다자 & 합계 & 양자 무상 & 다자 & 합계 \\
\hline 교육부 & 697.6 & - & 697.6 & 786.9 & - & 786.9 \\
\hline
\end{tabular}

※ 다자성양자는 양자에 포함

○ '18년도 ODA 시행목표

- 수원국 교육당국, 교원 및 학생, 학교를 대상으로 추진하는 교육의 본질적인 기능 향상 지원에 집중

※ 수원국 교육부, 교원, 학생, 학교를 대상으로 교육의 본질적 기능에 집중한 교육 ODA

추진, 특정분야 전문영역의 인력양성, 역량강화 지역은 제외

- 교육 $\mathrm{ODA}$ 국제무대에 국내 전문가 및 전문기관 진출을 적극 지원하여 교육한류 확산

※ 유네스코 등 국제기구 국제공모 참여, 모니터링 등 컨설턴트 모집에 국내전문가 추천,

국제 컨퍼런스 발표자 추천 등

- 국제개발협력 사업 추진 절차에 따른 사업 기획

우주요 정책과제

- EDCF/KOICA 등 대형 인프라 사업에 대해 수원국 자체 유지·관리, 발전을 위한 전문인력 양성을 지원, 사업간 연계성을 강화로 효과성 제고

※ (예) (EDCF) 요르단 연구용 원자로 지원 $\rightarrow$ (교육부) 국제협력 선도대학을 통해 요르단 과학기술대학교 원자력학과 교육의 질 제고 지원

- 양자 고위급 회의 또는 공동위 등 공식적 절차를 통해서 개발된 의제 중심 사업을 추진하여 수원국 요청을 적극 반영

※ 대학의 연구자, 개발자 중심의 의제 선정 지원 $\rightarrow$ 정부 부처 양자회의, 공동위 개발의제를 이행할 우수 연구자 공모

- 국제기구와의 공동으로 협력사업을 추진하여 수원국 주도의 현장 변화를 유도

※ (예) 아프리카 회원국 중심의 분야별 ICQN 활동과 협력사업 추진(직업, ICT 등)

$\square$ 유형별 분류

(억원, \%)

\begin{tabular}{|c|c|c|c|c|c|c|c|c|c|c|c|c|}
\hline \multirow[b]{2}{*}{ 구분 } & \multirow[b]{2}{*}{ 계 } & \multirow[b]{2}{*}{ 프로로 } & \multirow[b]{2}{*}{$\begin{array}{l}\text { 프로 } \\
\text { 그램 }\end{array}$} & \multirow[b]{2}{*}{$\begin{array}{c}\text { 개발 } \\
\text { 컨설팅 }\end{array}$} & \multicolumn{4}{|c|}{ 기술협력 } & \multirow{2}{*}{$\begin{array}{c}\text { 민관 } \\
\text { 협력 } \\
\text { (NGO, } \\
\text { 기업) }\end{array}$} & \multirow[b]{2}{*}{$\begin{array}{l}\text { 행정 } \\
\text { 비용 }\end{array}$} & \multirow[b]{2}{*}{ 기타 } & \multirow[b]{2}{*}{$\begin{array}{l}\text { 순수 } \\
\text { 다자* }\end{array}$} \\
\hline & & & & & $\begin{array}{l}\text { 연수 } \\
\text { 사업 }\end{array}$ & $\begin{array}{l}\text { 장학 } \\
\text { 지원 }\end{array}$ & $\begin{array}{l}\text { 봉사단 } \\
\text { 파견 }\end{array}$ & $\begin{array}{l}\text { 기타 } \\
\text { 기술 } \\
\text { 협력 }\end{array}$ & & & & \\
\hline \multirow{2}{*}{ '17년 } & 697.6 & 77.3 & - & - & - & 413.8 & - & 153.4 & 53.1 & - & - & - \\
\hline & 100 & 11.1 & - & - & - & 59.3 & - & 22.0 & 7.6 & - & - & - \\
\hline '18년 & 786.9 & 87.5 & - & - & 13.4 & 466.9 & - & 140.1 & 78.9 & - & - & - \\
\hline (요구) & 100 & 11.1 & $\begin{array}{l}\cdots \\
-\end{array}$ & $\cdots$ & 1.7 & 59.3 & $\begin{array}{l}\cdots \\
-\end{array}$ & 17.8 & 10.0 & $\cdots$ & $\cdots$ & $\begin{array}{l}\cdots \\
-\end{array}$ \\
\hline
\end{tabular}

* 다자성양자를 제외한 순수다자만 해당되며, 다자성양자는 사업 유형에 맞게 분류 


\begin{tabular}{|c|c|c|c|c|c|c|c|c|c|}
\hline & 세부사업명 & 내역사업명 & 사업 유형 & $\begin{array}{l}\text { 총사업예산 } \\
\text { (억원) }\end{array}$ & $\begin{array}{c}\text { '18년예산 } \\
\text { (억원) }\end{array}$ & $\begin{array}{l}\text { 신규/ } \\
\text { 계속 }\end{array}$ & $\begin{array}{l}\text { 총사업 } \\
\text { 기간 }\end{array}$ & $\begin{array}{c}\text { 구분 } \\
\text { (양-다자) }\end{array}$ & $\begin{array}{l}\text { SDGs } \\
\text { 목표 }\end{array}$ \\
\hline 1 & $\begin{array}{l}\text { 대학국제협력활성화지 } \\
\text { 원 }\end{array}$ & \begin{tabular}{|l|} 
국제협력선도대학육성 \\
지원사업 \\
(스리랑카_인제대)
\end{tabular} & 민관협력 & 17.80 & 1.00 & 계속 & $2013-2018$ & 양자무상 & 4 \\
\hline 2 & $\begin{array}{l}\text { 대학국제협력활성화지 } \\
\text { 원 }\end{array}$ & \begin{tabular}{|l|} 
국제협력선도대학육성 \\
지원사업 \\
(네팔_창원대)
\end{tabular} & 민관협력 & 18.90 & 1.00 & 계속 & $2014-2019$ & 양자무상 & 4 \\
\hline 3 & $\begin{array}{l}\text { 대학국제협력활성화지 } \\
\text { 원 }\end{array}$ & \begin{tabular}{|l|} 
국제협력선도대학육성 \\
지원사업 \\
(베트남_가천대)
\end{tabular} & 민관협력 & 18.18 & 1.00 & 계속 & $2014-2019$ & 양자무상 & 4 \\
\hline 4 & $\begin{array}{l}\text { 대학국제협력활성화지 } \\
\text { 원 }\end{array}$ & $\begin{array}{l}\text { 국제협력선도대학육성 } \\
\text { 지원사업 } \\
\text { (우즈베키스탄_고려 } \\
\text { 대) }\end{array}$ & 민관협력 & 16.24 & 4.00 & 계속 & $2016-2020$ & 양자무상 & 4 \\
\hline 5 & $\begin{array}{l}\text { 대학국제협력활성화지 } \\
\text { 원 }\end{array}$ & $\begin{array}{l}\text { 국제협력선도대학육성 } \\
\text { 지원사업 } \\
\text { (인도네시아_서강대) }\end{array}$ & 민관협력 & 16.24 & 4.00 & 계속 & $2016-2020$ & 양자무상 & 4 \\
\hline 6 & $\begin{array}{l}\text { 대학국제협력활성화지 } \\
\text { 원 }\end{array}$ & $\begin{array}{l}\text { 국제협력선도대학육성 } \\
\text { 지원사업 } \\
\text { (이집트_한국교육기술 } \\
\text { 대) }\end{array}$ & 민관협력 & 16.24 & 4.00 & 계속 & $2016-2020$ & 양자무상 & 4 \\
\hline 7 & $\begin{array}{l}\text { 대학국제협력활성화지 } \\
\text { 원 }\end{array}$ & $\begin{array}{l}\text { 국제협력선도대학육성 } \\
\text { 지원사업 } \\
\text { (라오스_배제대) }\end{array}$ & 민관협력 & 16.24 & 4.00 & 계속 & $2017-2021$ & 양자무상 & 4 \\
\hline 8 & $\begin{array}{l}\text { 대학국제협력활성화지 } \\
\text { 원 }\end{array}$ & $\begin{array}{l}\text { 국제협력선도대학육성 } \\
\text { 지원사업 } \\
\text { (미얀마_전북대) }\end{array}$ & 민관협력 & 16.24 & 4.00 & 계속 & $2017-2021$ & 양자무상 & 4 \\
\hline 9 & $\begin{array}{l}\text { 대학국제협력활성화지 } \\
\text { 원 }\end{array}$ & $\begin{array}{l}\text { 국제협력선도대학육성 } \\
\text { 지원사업 } \\
\text { (몽골_조선대) }\end{array}$ & 민관협력 & 16.24 & 4.00 & 계속 & $2017-2021$ & 양자무상 & 4 \\
\hline 10 & $\begin{array}{l}\text { 대학국제협력활성화지 } \\
\text { 원 }\end{array}$ & $\begin{array}{l}\text { 국제협력선도대학육성 } \\
\text { 지원사업 } \\
\text { (가나_연세대) }\end{array}$ & 민관협력 & 16.24 & 4.00 & 계속 & $2017-2021$ & 양자무상 & 4 \\
\hline 11 & $\begin{array}{l}\text { 대학국제협력활성화지 } \\
\text { 원 }\end{array}$ & $\begin{array}{l}\text { 국제협력선도대학육성 } \\
\text { 지원사업 } \\
\text { (몽골_원광보건대) }\end{array}$ & 민관협력 & 18.00 & 4.00 & 신규 & $2018-2023$ & 양자무상 & 4 \\
\hline 12 & $\begin{array}{l}\text { 대학국제협력활성화지 } \\
\text { 원 }\end{array}$ & $\begin{array}{l}\text { 국제협력선도대학육성 } \\
\text { 지원사업 } \\
\text { (몽골_한국산업기술 } \\
\text { 대) }\end{array}$ & 민관협력 & 18.00 & 4.00 & 신규 & $2018-2023$ & 양자무상 & 4 \\
\hline 13 & $\begin{array}{l}\text { 대학국제협력활성화지 } \\
\text { 원 }\end{array}$ & $\begin{array}{l}\text { 국제협력선도대학육성 } \\
\text { 지원사업 } \\
\text { (캄보디아_공주대) }\end{array}$ & 민관협력 & 18.00 & 4.00 & 신규 & $2018-2023$ & 양자무상 & 4 \\
\hline 14 & $\begin{array}{l}\text { 대학국제협력활성화지 } \\
\text { 원 }\end{array}$ & $\begin{array}{l}\text { 국제협력선도대학육성 } \\
\text { 지원사업 } \\
\text { (캄보디아_전남대) }\end{array}$ & 민관협력 & 18.00 & 4.00 & 신규 & $2018-2023$ & 양자무상 & 4 \\
\hline 15 & $\begin{array}{l}\text { 대학국제협력활성화지 } \\
\text { 원 }\end{array}$ & $\begin{array}{l}\text { 국제협력선도대학육성 } \\
\text { 지원사업 } \\
\text { (르완다) }\end{array}$ & 민관협력 & 18.00 & 4.00 & 신규 & $2018-2023$ & 양자무상 & 4 \\
\hline 16 & $\begin{array}{l}\text { 대학국제협력활성화지 } \\
\text { 원 }\end{array}$ & $\begin{array}{l}\text { 국제협력선도대학육성 } \\
\text { 지원사업 } \\
\text { (요르단) }\end{array}$ & 민관협력 & 18.00 & 4.00 & 신규 & $2018-2023$ & 양자무상 & 4 \\
\hline 17 & $\begin{array}{l}\text { 대학국제협력활성화지 } \\
\text { 원 }\end{array}$ & \begin{tabular}{|l|} 
국제협력선도대학육성 \\
지원사업 \\
(방글라데시)
\end{tabular} & 민관협력 & 18.00 & 4.00 & 신규 & $2018-2023$ & 양자무상 & 4 \\
\hline 18 & $\begin{array}{l}\text { 대학국제협력활성화지 } \\
\text { 원 }\end{array}$ & $\begin{array}{l}\text { 아세안대학 이러닝 지 } \\
\text { 원(라오스) }\end{array}$ & 프로젝트 & 22.14 & 3.85 & 계속 & 2012 계속 & 양자무상 & 4 \\
\hline 19 & $\begin{array}{l}\text { 대학국제협력활성화지 } \\
\text { 원 }\end{array}$ & $\begin{array}{l}\text { 아세안대학 이러닝 지 } \\
\text { 원(미얀마) }\end{array}$ & 프로젝트 & 22.14 & 3.85 & 계속 & 2012 계속 & 양자무상 & 4 \\
\hline 20 & $\begin{array}{l}\text { 대학국제협력활성화지 } \\
\text { 원 }\end{array}$ & $\begin{array}{l}\text { 아세안대학 이러닝 지 } \\
\text { 원(베트남) }\end{array}$ & 프로젝트 & 22.14 & 3.85 & 계속 & 2012 계속 & 양자무상 & 4 \\
\hline
\end{tabular}




\begin{tabular}{|c|c|c|c|c|c|c|c|c|c|}
\hline & 세부사업명 & 내역사업명 & 사업 유형 & $\begin{array}{c}\text { 총사업예산 } \\
\text { (억원) }\end{array}$ & $\begin{array}{l}18 \text { 년 예산 } \\
\text { (억원) }\end{array}$ & $\begin{array}{l}\text { 신규/ } \\
\text { 계속 } \\
\end{array}$ & $\begin{array}{l}\text { 총사업 } \\
\text { 기간 }\end{array}$ & \begin{tabular}{|c|} 
구분 \\
(양-다자)
\end{tabular} & $\begin{array}{l}\text { SDGS } \\
\text { 목표 }\end{array}$ \\
\hline 21 & $\begin{array}{l}\text { 대학국제협력활성화지 } \\
\text { 원 }\end{array}$ & $\begin{array}{l}\text { 아세안대학 이러닝 } \\
\text { 지원(캄보디아) }\end{array}$ & 프로젝트 & 22.14 & 3.85 & 계속 & 2012 계속 & 양자무상 & 4 \\
\hline 22 & $\begin{array}{l}\text { 국제교육교류협력활성 } \\
\text { 화 }\end{array}$ & 교원해외파견사업 & 기타기술협력 & & 73.03 & 계속 & 2013-계속 & 양자무상 & 4 \\
\hline 23 & $\begin{array}{l}\text { 국제교육교류협력활성 } \\
\text { 화 }\end{array}$ & 글로벌코리아스칼라십 & 장학지원 & $4,924.37$ & 422.91 & 계속 & 1967 -계속 & 양자무상 & 4 \\
\hline 24 & $\begin{array}{l}\text { 글로벌교육지원사업 } \\
\text { (ODA) }\end{array}$ & 글로벌 교육 지원 & 민관협력 & 10.00 & 10.00 & 계속 & 2018 & 양자무상 & 4 \\
\hline 25 & $\begin{array}{l}\text { 글로벌교육지원사업 } \\
\text { (ODA) }\end{array}$ & $\begin{array}{l}\text { 다문화가정대상국가와 } \\
\text { 의 교사교류 }\end{array}$ & 기타기술협력 & 160.81 & 27.00 & 계속 & $\begin{array}{l}\text { 2012년- } \\
\text { 계속 }\end{array}$ & 양자무상 & 4 \\
\hline 26 & $\begin{array}{l}\text { 글로벌교육지원사업 } \\
\text { (ODA) }\end{array}$ & $\begin{array}{l}\text { 세계시민교육(GCED) } \\
\text { 역량강화지원 } \\
\text { (유네스코APCEIU) }\end{array}$ & 프로젝트 & 36.00 & 13.00 & 계속 & $2016-2018$ & 다자성양자 & 4 \\
\hline 27 & $\begin{array}{l}\text { 저개발국교육인재양성 } \\
\text { 지원 }\end{array}$ & 브릿지 아프리카(레소토) & 민관협력 & 3.78 & 0.70 & 계속 & $\begin{array}{l}2013 \sim \\
2020\end{array}$ & 양자무상 & 4 \\
\hline 28 & $\begin{array}{l}\text { 저개발국교육인재양성 } \\
\text { 지원 }\end{array}$ & 브릿지 아프리카(르완다) & 민관협력 & 4.82 & 0.70 & 계속 & $\begin{array}{l}2013 \sim \\
2020\end{array}$ & 양자무상 & 4 \\
\hline 29 & $\begin{array}{l}\begin{array}{l}\text { 저개발국교육인재양성 } \\
\text { 지원 }\end{array} \\
\end{array}$ & 브릿지 아프리카(말라위) & 민관협력 & 5.51 & 0.70 & 계속 & $\begin{array}{c}2013 \sim \\
2020 \\
\end{array}$ & 양자무상 & 4 \\
\hline 30 & $\begin{array}{l}\text { 저개발국교육인재양성 } \\
\text { 지원 }\end{array}$ & 브릿지 아프라카(보츠와나) & 민관협력 & 0.70 & 0.70 & 신규 & $\begin{array}{l}2018 \sim \\
2020\end{array}$ & 양자무상 & 4 \\
\hline 31 & $\begin{array}{l}\text { 저개발국교육인재양성 } \\
\text { 지원 }\end{array}$ & $\begin{array}{l}\text { 브릿지 아프리카(스와질 } \\
\text { 란드) }\end{array}$ & 민관협력 & 1.06 & 0.70 & 신규 & $\begin{array}{l}2018 \sim \\
2020\end{array}$ & 양자무상 & 4 \\
\hline 32 & $\begin{array}{l}\begin{array}{l}\text { 저개발국교육인재양성 } \\
\text { 지원 }\end{array} \\
\end{array}$ & 브릿지 아프리카(잠비아) & 민관협력 & 4.91 & 0.70 & 계속 & $\begin{array}{l}2013 \sim \\
2020\end{array}$ & 양자무상 & 4 \\
\hline 33 & $\begin{array}{l}\text { 저개발국교육인재양성 } \\
\text { 지원 }\end{array}$ & $\begin{array}{l}\text { 브릿지 아프리카(짐바브 } \\
\text { 웨) }\end{array}$ & 민관협력 & 3.18 & 0.70 & 계속 & $\begin{array}{l}2013 \sim \\
2020\end{array}$ & 양자무상 & 4 \\
\hline 34 & $\begin{array}{l}\text { UNESCO 저개발국 } \\
\text { 교육지원 }\end{array}$ & $\begin{array}{l}\text { 유네스코 개발도상국 } \\
\text { 학생 초청 직업교육 } \\
\text { 사업 }\end{array}$ & 장학지원 & 777.00 & 27.00 & 신규 & $\begin{array}{l}2018 \sim \\
2027\end{array}$ & 양자무상 & 4 \\
\hline 35 & $\begin{array}{l}\text { UNESCO 저개발국 } \\
\text { 교육지원 }\end{array}$ & $\begin{array}{l}\text { UNESCO UNITWIN } \\
\text { 사업(한동대) }\end{array}$ & 기타기술협력 & 90.82 & 20.00 & 계속 & $2010 \sim 2019$ & 양자무상 & 5 \\
\hline 36 & $\begin{array}{l}\text { UNESCO 저개발국 } \\
\text { 교육지원 }\end{array}$ & $\begin{array}{l}\text { UNESCO UNITWIN } \\
\text { 사업(숙명여대) }\end{array}$ & 기타기술협력 & 10.84 & 4.70 & 계속 & $2016 \sim 2020$ & 양자무상 & 4 \\
\hline 37 & $\begin{array}{l}\text { UNESCO 저개발국 } \\
\text { 교육지원 }\end{array}$ & $\begin{array}{l}\text { UNESCO UNITWIN } \\
\text { 사업(방송대) }\end{array}$ & 기타기술협력 & 20.00 & 4.00 & 신규 & $2017 \sim 2021$ & 양자무상 & 4 \\
\hline 38 & $\begin{array}{l}\text { UNESCO 저개발국 } \\
\text { 교육지원 }\end{array}$ & $\begin{array}{l}\text { BEAR I 지속성 강화 } \\
\text { 사업 (보츠와나) }\end{array}$ & 기타기술협력 & 3.00 & 0.60 & 계속 & $2016 \sim 2020$ & 양자무상 & 4 \\
\hline 39 & $\begin{array}{l}\text { UNESCO 저개발국 } \\
\text { 교육지원 }\end{array}$ & $\begin{array}{l}\mathrm{BEAR} \text { I 지속성 강화 } \\
\text { 사업 (DR 콩고) }\end{array}$ & 기타기술협력 & 3.00 & 0.60 & 계속 & $2016 \sim 2020$ & 양자무상 & 4 \\
\hline 40 & $\begin{array}{l}\text { UNESCO 저개발국 } \\
\text { 교육지원 }\end{array}$ & $\begin{array}{l}\text { BEAR I 지속성 강화 } \\
\text { 사업 (말라위) }\end{array}$ & 기타기술협력 & 3.00 & 0.60 & 계속 & $2016 \sim 2020$ & 양자무상 & 4 \\
\hline 41 & $\begin{array}{l}\text { UNESCO 저개발국 } \\
\text { 교육지원 }\end{array}$ & $\begin{array}{l}\text { BEAR I 지속성 강화 } \\
\text { 사업 (나미비아) }\end{array}$ & 기타기술협력 & 3.00 & 0.60 & 계속 & $2016 \sim 2020$ & 양자무상 & 4 \\
\hline 42 & $\begin{array}{l}\text { UNESCO 저개발국 } \\
\text { 교육지원 }\end{array}$ & $\begin{array}{l}\mathrm{BEAR} \mathrm{I} \mathrm{지속성} \mathrm{강화} \\
\text { 사업 (잠비아) }\end{array}$ & 기타기술협력 & 3.00 & 0.60 & 계속 & $2016 \sim 2020$ & 양자무상 & 4 \\
\hline 43 & $\begin{array}{l}\text { UNESCO 저개발국 } \\
\text { 교육지원 }\end{array}$ & $\begin{array}{l}\text { 아프리카 저개발국 } \\
\text { 직업기술교육지원 사 } \\
\text { 업(2차) }\end{array}$ & 프로젝트 & 115.00 & 26.45 & 계속 & $2016-2020$ & 다자성양자 & 4 \\
\hline 44 & $\begin{array}{l}\text { UNESCO 저개발국 } \\
\text { 교육지원 }\end{array}$ & 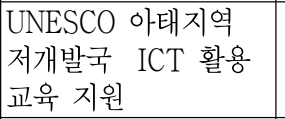 & 프로젝트 & 17.25 & 6.21 & 계속 & $2017-2020$ & 다자성양자 & 4 \\
\hline 45 & $\begin{array}{l}\text { UNESCO 저개발국 } \\
\text { 교육지원 }\end{array}$ & $\begin{array}{l}\text { UNESCO 아태지역 } \\
\text { 소통과 통합 증진을 } \\
\text { 위한 교육협력 }\end{array}$ & 프로젝트 & 23.00 & 5.21 & 계속 & $2015-2018$ & 다자성양자 & 4 \\
\hline 46 & $\begin{array}{l}\text { UNESCO 저개발국 } \\
\text { 교육지원 }\end{array}$ & $\begin{array}{l}\text { UNESCO 아프리카 } \\
\text { ICT 활용 교육혁신 } \\
\text { 지원 }\end{array}$ & 프로젝트 & 69.00 & 9.66 & 계속 & $2015-2018$ & 다자성양자 & 4 \\
\hline 47 & 이러닝 세계화 & $\begin{array}{l}\text { 교류협력국교육정보화 } \\
\text { 지원 } \\
\text { (선도교원초청연수및 } \\
\text { 인프라지원_캄보디아) }\end{array}$ & 연수사업 & 0.79 & 0.79 & 신규 & 2018 & 양자무상 & 4 \\
\hline
\end{tabular}




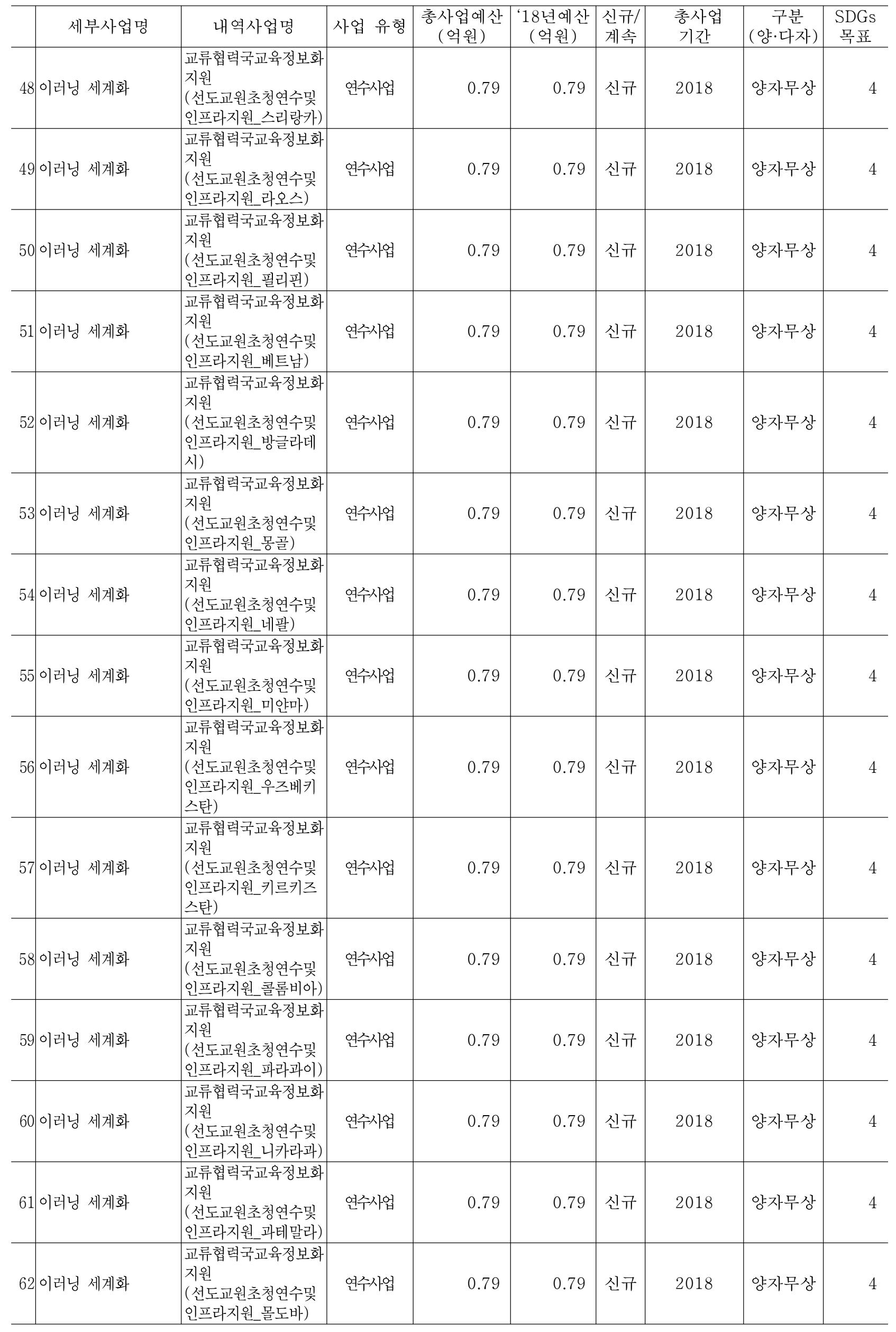




\begin{tabular}{|c|c|c|c|c|c|c|c|c|c|}
\hline & 세부사업명 & 내역사업명 & 사업 유형 & $\begin{array}{c}\text { 총사업 예산 } \\
\text { (억 원) }\end{array}$ & $\begin{array}{l}\text { '18년예산 } \\
\text { (억원) }\end{array}$ & $\begin{array}{l}\text { 신규/ } \\
\text { 계속 }\end{array}$ & $\begin{array}{l}\text { 총사업 } \\
\text { 기간 }\end{array}$ & $\begin{array}{c}\text { 구분 } \\
\text { (양-다자) }\end{array}$ & $\begin{array}{l}\text { SDGs } \\
\text { 목표 }\end{array}$ \\
\hline 63 & 이러닝 세계화 & \begin{tabular}{|l|} 
교류협력국교육정보화 \\
지원 \\
(선도교원초청연수및 \\
인프라지원_케냐)
\end{tabular} & 연수사업 & 0.79 & 0.79 & 신규 & 2018 & 양자무상 & 4 \\
\hline 64 & 이러닝 세계화 & \begin{tabular}{|l|} 
교류협력국교육정보화 \\
지원 \\
(이러닝국제컨설팅)
\end{tabular} & 기타기술협력 & 20.39 & 0.75 & 계속 & $\begin{array}{l}2006 \text { } \\
\text { 계속 }\end{array}$ & 양자무상 & 4 \\
\hline 65 & 이러닝 세계화 & $\begin{array}{l}\text { 국제기구 및 다자간 } \\
\text { 이러닝 협력 추진 }\end{array}$ & 기타기술협력 & 73.30 & 7.35 & 계속 & $\begin{array}{l}2006 \sim \\
\text { 계속 }\end{array}$ & 양자무상 & 4 \\
\hline 66 & 이러닝 세계화 & $\begin{array}{l}\text { 첨단 ICT 활용 시범 } \\
\text { 교실 구축운영지원 } \\
\text { (르완다) }\end{array}$ & 프로젝트 & 9.21 & 6.85 & 신규 & $\begin{array}{l}2018 \sim \\
2022\end{array}$ & 양자무상 & 4 \\
\hline 67 & 이러닝 세계화 & $\begin{array}{l}\text { 첨단 ICT 활용 시범 } \\
\text { 교실 구축운영지원 } \\
\text { (네팔) }\end{array}$ & 프로젝트 & 8.33 & 1.48 & 계속 & $\begin{array}{l}2017 \sim \\
2021\end{array}$ & 양자무상 & 4 \\
\hline 68 & 이러닝 세계화 & $\begin{array}{l}\text { 첨단 ICT 활용 시범 } \\
\text { 교실 구축운영지원 } \\
\text { (케냐) }\end{array}$ & 프로젝트 & 8.33 & 1.48 & 계속 & $\begin{array}{l}2017 \sim \\
2021\end{array}$ & 양자무상 & 4 \\
\hline 69 & 이러닝 세계화 & $\begin{array}{l}\text { 첨단 ICT 활용 시범 } \\
\text { 교실 구축운영지원 } \\
\text { (라오스) }\end{array}$ & 프로젝트 & 8.71 & 0.38 & 계속 & $\begin{array}{l}2016 \sim \\
2020\end{array}$ & 양자무상 & 4 \\
\hline 70 & 이러닝 세계화 & $\begin{array}{l}\text { 첨단 ICT 활용 시범 } \\
\text { 교실 구축운영지원 } \\
\text { (페루) }\end{array}$ & 프로젝트 & 8.71 & 0.38 & 계속 & $\begin{array}{l}2016 \sim \\
2020\end{array}$ & 양자무상 & 4 \\
\hline 71 & 이러닝 세계화 & $\begin{array}{l}\text { 첨단 ICT 활용 시범 } \\
\text { 교실 구축운영지원 } \\
\text { (스리랑카) }\end{array}$ & 프로젝트 & 9.21 & 0.50 & 계속 & $\begin{array}{l}2014 \sim \\
2018\end{array}$ & 양자무상 & 4 \\
\hline 72 & 이러닝 세계화 & $\begin{array}{l}\text { 첨단 ICT 활용 시범 } \\
\text { 교실 구축운영지원 } \\
\text { (파라과이) }\end{array}$ & 프로젝트 & 9.21 & 0.50 & 계속 & $\begin{array}{l}2014 \sim \\
2018\end{array}$ & 양자무상 & 4 \\
\hline 73 & 이러닝세계화 & $\begin{array}{l}\text { 솔라스쿨 활용 교육 } \\
\text { 지원(케냐) }\end{array}$ & 민관협력 & 3.39 & 0.68 & 계속 & $\begin{array}{l}2013 \sim \\
2018 \\
\end{array}$ & 양자무상 & 4 \\
\hline 74 & 이러닝세계화 & $\begin{array}{l}\text { 솔라스쿨 활용 교육 } \\
\text { 지원(가나) }\end{array}$ & 민관협력 & 3.19 & 0.48 & 계속 & $\begin{array}{l}2013 \sim \\
2018\end{array}$ & 양자무상 & 4 \\
\hline 75 & 이러닝세계화 & $\begin{array}{l}\text { 솔라스쿨 활용 교육 } \\
\text { 지원(에티오피아) }\end{array}$ & 민관협력 & 3.19 & 0.48 & 계속 & $\begin{array}{l}2013 \sim \\
2018\end{array}$ & 양자무상 & 4 \\
\hline 76 & 이러닝세계화 & $\begin{array}{l}\text { 솔라스쿨 활용 교육 } \\
\text { 지원(우간다) }\end{array}$ & 민관협력 & 1.86 & 0.68 & 계속 & $\begin{array}{l}2016 \sim \\
2020 \\
\end{array}$ & 양자무상 & 4 \\
\hline 77 & 이러닝세계화 & $\begin{array}{l}\text { 솔라스쿨 활용 교육 } \\
\text { 지원(르완다) }\end{array}$ & 민관협력 & 1.66 & 0.48 & 계속 & $\begin{array}{l}2016 \sim \\
2020\end{array}$ & 양자무상 & 4 \\
\hline 78 & 이러닝세계화 & $\begin{array}{l}\text { 솔라스쿨 활용 교육 } \\
\text { 지원(모잠비크) }\end{array}$ & 민관협력 & 1.66 & 0.48 & 계속 & $\begin{array}{l}2016 \sim \\
2020\end{array}$ & 양자무상 & 4 \\
\hline 79 & 이러닝세계화 & $\begin{array}{l}\text { 솔라스쿨 활용 교육 } \\
\text { 지원(잠비아) }\end{array}$ & 민관협력 & 1.22 & 0.68 & 계속 & $\begin{array}{l}2017 \sim \\
2021\end{array}$ & 양자무상 & 4 \\
\hline 80 & 이러닝세계화 & $\begin{array}{l}\text { 솔라스쿨 활용 교육 } \\
\text { 지원(짐바브웨) }\end{array}$ & 민관협력 & 1.02 & 0.48 & 계속 & $\begin{array}{l}2017 \sim \\
2021\end{array}$ & 양자무상 & 4 \\
\hline 81 & 이러닝세계화 & $\begin{array}{l}\text { 솔라스쿨 활용 교육 } \\
\text { 지원(탄자니아) }\end{array}$ & 민관협력 & 1.01 & 0.48 & 계속 & $\begin{array}{l}2017 \sim \\
2021\end{array}$ & 양자무상 & 4 \\
\hline 82 & 이러닝세계화 & $\begin{array}{l}\text { 솔라스쿨 활용 교육 } \\
\text { 지원(보츠와나) }\end{array}$ & 민관협력 & 0.31 & 0.31 & 신규 & $\begin{array}{c}2018 \sim \\
2022\end{array}$ & 양자무상 & 4 \\
\hline 83 & 이러닝세계화 & $\begin{array}{l}\text { 솔라스쿨 활용 교육 } \\
\text { 지원(나미비아) }\end{array}$ & 민관협력 & 0.31 & 0.31 & 신규 & $\begin{array}{l}2018 \sim \\
2022\end{array}$ & 양자무상 & 4 \\
\hline 84 & 이러닝세계화 & $\begin{array}{l}\text { 솔라스쿨 활용 교육 } \\
\text { 지원(말라위) }\end{array}$ & 민관협력 & 0.31 & 0.31 & 신규 & $\begin{array}{l}2018 \sim \\
2022\end{array}$ & 양자무상 & 4 \\
\hline
\end{tabular}




\section{미래창조과학부 2018년도 ODA 예산 계획[안]}

\section{$\square$ 총괄}

(단위: 억원)

\begin{tabular}{l|c|c|c||c|c|c}
\hline \multirow{2}{*}{ ODA 시행부처(기관) } & \multicolumn{3}{|c||}{2017} & \multicolumn{3}{c}{2018 (요구) } \\
\cline { 2 - 7 } & 양자 무상 & 다자 & 합계 & 양자 무상 & 다자 & 합계 \\
\hline 미래창조과학부 & 112.4 & 12.4 & 124.9 & 157.1 & 13.4 & 170.5 \\
\hline
\end{tabular}

※ 다자성양자는 양자에 포함

○ '18년도 ODA 시행목표

- 과학기술 및 ICT 사업을 통해 개도국의 지속가능한 발전 및 협력대상국과의 경제협력 관계 증진

\section{$\square$ 유형별 분류}

(억원, \%)

\begin{tabular}{|c|c|c|c|c|c|c|c|c|c|c|c|c|}
\hline \multirow[b]{2}{*}{ 구분 } & \multirow[b]{2}{*}{ 계 } & \multirow[b]{2}{*}{ 프로 } & \multirow[b]{2}{*}{ 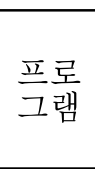 } & \multirow[b]{2}{*}{$\begin{array}{l}\text { 개발 } \\
\text { 컨설팅 }\end{array}$} & \multicolumn{4}{|c|}{ 기술협력 } & \multirow{2}{*}{$\begin{array}{c}\text { 민관 } \\
\text { 협력 } \\
\text { (NGO, } \\
\text { 기업) }\end{array}$} & \multirow[b]{2}{*}{$\begin{array}{l}\text { 행정 } \\
\text { 비용 }\end{array}$} & \multirow[b]{2}{*}{ 기타 } & \multirow[b]{2}{*}{$\begin{array}{l}\text { 순수 } \\
\text { 다자* }\end{array}$} \\
\hline & & & & & $\begin{array}{l}\text { 연수업 } \\
\text { 사업 }\end{array}$ & $\begin{array}{l}\text { 장항 } \\
\text { 지원 }\end{array}$ & $\begin{array}{l}\text { 봉사단 } \\
\text { 파견 }\end{array}$ & $\begin{array}{l}\text { 기타 } \\
\text { 기술 } \\
\text { 협력 }\end{array}$ & & & & \\
\hline \multirow{2}{*}{ '17년 } & 124.9 & 49.9 & - & 8.3 & 23.7 & - & - & 21.9 & - & - & 8.7 & 12.4 \\
\hline & 100 & 40.0 & - & 6.6 & 18.9 & - & - & 17.5 & - & - & 7.0 & 9.9 \\
\hline '18년 & 170.5 & 79.7 & - & 22 & 18.9 & - & - & 8.5 & 9.5 & - & 18.5 & 13.4 \\
\hline (요구) & 100 & 46.7 & - & 12.9 & 11.1 & $\cdots$ & - & 5.0 & 5.7 & - & 10.8 & 7.8 \\
\hline
\end{tabular}

* 다자성양자를 제외한 순수다자만 해당되며, 다자성양자는 사업 유형에 맞게 분류

\section{$\square$ 총 사업 목록}

\begin{tabular}{|c|c|c|c|c|c|c|c|c|c|}
\hline & 세부사업명 & 내역사업명 & 사업 유형 & $\begin{array}{c}\text { 총사업 예산 } \\
\text { (억원) }\end{array}$ & \begin{tabular}{|c} 
'18년예산 \\
(억원)
\end{tabular} & \begin{tabular}{|l|} 
신규/ \\
계속
\end{tabular} & $\begin{array}{l}\text { 총사업 } \\
\text { 기간 }\end{array}$ & $\begin{array}{c}\text { 구분 } \\
\text { (양-다자) }\end{array}$ & $\begin{array}{l}\text { SDGs } \\
\text { 목표 }\end{array}$ \\
\hline 1 & 개도국과학기술지원사업 & $\begin{array}{l}\text { 기관 간 협력지원(인 } \\
\text { 도네시아) }\end{array}$ & 민관협력 & 3.00 & 1.00 & 계속 & '16 '18 & 양자무상 & 6 \\
\hline 2 & 개도국과학기술지원사업 & $\begin{array}{l}\text { 기관 간 협력지원(아 } \\
\text { 제르바이잔) }\end{array}$ & 민관협력 & 1.00 & 1.00 & 신규 & '18 & 양자무상 & 2 \\
\hline 3 & 개도국과학기술지원사업 & $\begin{array}{l}\text { 기관 간 협력지원(라 } \\
\text { 오스) }\end{array}$ & 민관협력 & 3.00 & 1.00 & 계속 & '17 '19 & 양자무상 & 1 \\
\hline 4 & 개도국과학기술지원사업 & $\begin{array}{l}\text { 기관 간 협력지원(스 } \\
\text { 리랑카) }\end{array}$ & 민관협력 & 3.00 & 1.00 & 신규 & '18 '19 & 양자무상 & 9 \\
\hline 5 & 개도국포 & $\begin{array}{l}\text { 기관 간 협력지원(캄 } \\
\text { 보디아) }\end{array}$ & 민관협력 & 3.00 & 1.00 & 신규 & '18 ' 20 & 양자무상 & 4 \\
\hline 6 & 개도국과학기술지원사업 & $\begin{array}{l}\text { 기관 간 협력지원(베 } \\
\text { 트맘) }\end{array}$ & 민관협력 & 1.00 & 1.00 & 신규 & '18 & 양자무상 & 14 \\
\hline 7 & 개도국고 & $\begin{array}{l}\text { 기관 간 협력지원(에 } \\
\text { 티오피아) }\end{array}$ & 민관협력 & 1.00 & 1.00 & 신규 & '18 & 양자무상 & 6 \\
\hline 8 & 개도국과학기술 & $\begin{array}{l}\text { 기관 간 협력지원(베 } \\
\text { 트남) }\end{array}$ & 민관협력 & 0.80 & 0.80 & 신규 & '18 & 양자무상 & 3 \\
\hline 9 & 개도국과흐 & 기관 간 협력지원(네팔) & 미과혁르 & 0 & 070 & 신규 & '18 & 양자무상 & 3 \\
\hline 10 & 개도국과 & 기관 간 협력지원(네팔) & 닌난 & 1.00 & 00 & 신규 & '18 & 양자무상 & 15 \\
\hline 11 & 개도국과학기술지원사업 & $\begin{array}{l}\text { 적정과학기술 거점센 } \\
\text { 터 지원(네팔) }\end{array}$ & 프로젝트 & 20.00 & 5.00 & 계속 & '15 '18 & 양자무상 & 7 \\
\hline 12 & 개도국과학기술지원사업 & $\begin{array}{l}\text { 적정과학기술 거점센 } \\
\text { 터 지원(탄자니아) }\end{array}$ & 프로젝트 & 20.00 & 5.00 & 계속 & '17 & 루상 & 7 \\
\hline
\end{tabular}




\begin{tabular}{|c|c|c|c|c|c|c|c|c|c|}
\hline & 세부사업명 & 내역사업명 & 사업 유형 & $\begin{array}{c}\begin{array}{c}\text { 총사업예산 } \\
\text { (억원) }\end{array} \\
\end{array}$ & $\begin{array}{c}18 \text { 년예산 } \\
\text { (억원) }\end{array}$ & $\begin{array}{l}\text { 신규/ } \\
\text { 계속 }\end{array}$ & $\begin{array}{l}\text { 총사업 } \\
\text { 기간 }\end{array}$ & \begin{tabular}{c|} 
구분 \\
(양.다자) \\
\end{tabular} & $\begin{array}{l}\text { SDGs } \\
\text { 목표 }\end{array}$ \\
\hline 13 & 개도국과학기술지원사업 & \begin{tabular}{|l|l|}
\multicolumn{2}{|l}{ 적정과학기술 거점센 } \\
터 & 지원(에티오피아)
\end{tabular} & 프로젝트 & 20.00 & 5.00 & 계속 & '17 '20 & 양자무상 & 17 \\
\hline 14 & 개도국과학기슬 & $\begin{array}{l}\text { 적정과학기술 거점센 } \\
\text { 터 지원(베트남) }\end{array}$ & 프로젝트 & 20.00 & 5.00 & 신규 & '18 '21 & 양자무상 & 6 \\
\hline 15 & 개도국과학기술지원사업 & $\begin{array}{l}\text { 적정과학기술 거점센 } \\
\text { 터 지원(필리핀) }\end{array}$ & 프로젝트 & 20.00 & 5.00 & 신규 & '18 '21 & 양자무상 & 9 \\
\hline 16 & 개도국과학기술지원사업 & $\begin{array}{l}\text { 적정과학기술 거점센 } \\
\text { 터 지원(캄보디아) }\end{array}$ & 프로젝트 & 1.00 & 1.00 & 신규 & '18 & 양자무상 & 6 \\
\hline & 개도국과학기술지원사업 & $\begin{array}{l}\text { 적정과학기술 거점센 } \\
\text { 터 지원(라오스) }\end{array}$ & 프로젝트 & 2.00 & 1.00 & 신규 & '18 '19 & 양자무상 & 8 \\
\hline & $\begin{array}{l}\text { 개도국 정보통신방송 } \\
\text { 개발협력 지원 }\end{array}$ & $\begin{array}{l}\text { 개도국 정보통신방송 } \\
\text { 전문가 초청연수 }\end{array}$ & 연수사업 & 17.01 & 17.01 & 신규 & '18 & 양자무상 & 17 \\
\hline & $\begin{array}{l}\text { 개도국 정보통신방송 } \\
\text { 개발협력 지원 }\end{array}$ & $\begin{array}{l}\text { 개도국 정보통신방송 } \\
\text { 정책자문 (라오스) }\end{array}$ & 개발컨설팅 & 2.00 & 2.00 & 신규 & '18 & 양자무상 & 9 \\
\hline & $\begin{array}{l}\text { 개도국 정보통신방송 } \\
\text { 개발협력 지원 }\end{array}$ & $\begin{array}{l}\text { 개도국 정보통신방송 } \\
\text { 정책자문 (몰도바) }\end{array}$ & 개발컨설팅 & 2.00 & 2.00 & 신규 & '18 & 양자무상 & 9 \\
\hline & $\begin{array}{l}\text { 개도국 정보통신방송 } \\
\text { 개발협력 지원 }\end{array}$ & $\begin{array}{l}\text { 개도국 정보통신방송 } \\
\text { 정책자문 (세르비아) }\end{array}$ & 개발컨설팅 & 2.00 & 2.00 & 신규 & '18 & 양자무상 & 9 \\
\hline & $\begin{array}{l}\text { 개도국 정보통신방송 } \\
\text { 개발협력 지원 }\end{array}$ & $\begin{array}{l}\text { 개도국 정보통신방송 } \\
\text { 정책자문 (에콰도르) }\end{array}$ & 개발컨설팅 & 2.00 & 2.00 & 신규 & '18 & 양자무상 & 9 \\
\hline & $\begin{array}{l}\text { 개도국 정보통신방송 } \\
\text { 개발협력 지원 }\end{array}$ & $\begin{array}{l}\text { 개도국 정보통신방송 } \\
\text { 정책자문 (에티오피 } \\
\text { 아) }\end{array}$ & 개발컨설팅 & 2.00 & 2.00 & 신규 & '18 & 양자무상 & 9 \\
\hline & $\begin{array}{l}\text { 개도국 정보통신방송 } \\
\text { 개발협력 지원 }\end{array}$ & $\begin{array}{l}\text { 개도국 정보통신방송 } \\
\text { 정책자문 (우간다) }\end{array}$ & 개발컨설팅 & 2.00 & 2.00 & 신규 & '18 & 량자무상 & 9 \\
\hline & $\begin{array}{l}\text { 개도국 정보통신방송 } \\
\text { 개발협력 지원 }\end{array}$ & $\begin{array}{l}\text { 개도국 정보통신방송 } \\
\text { 정책자문 (우즈베키 } \\
\text { 스탄) }\end{array}$ & 개발컨설팅 & 2.00 & 2.00 & 신규 & '18 & 양자무상 & 9 \\
\hline & $\begin{array}{l}\text { 개도국 정보통신방송 } \\
\text { 개발협력 지원 }\end{array}$ & $\begin{array}{l}\text { 개도국 정보통신방송 } \\
\text { 정책자문 (콜롬비아) }\end{array}$ & 개발컨설팅 & 2.00 & 2.00 & 신규 & '18 & 양자무상 & 9 \\
\hline & $\begin{array}{l}\text { 개도국 정보통신방송 } \\
\text { 개발협력 지원 }\end{array}$ & $\begin{array}{l}\begin{array}{l}\text { 개도국 정보통신방송 } \\
\text { 정책자문 (키르기스 } \\
\text { 스탄) }\end{array} \\
\end{array}$ & 개발컨설팅 & 2.00 & 2.00 & 신규 & '18 & 자무상 & 9 \\
\hline & \begin{tabular}{|l|} 
개도국 정보통신방송 \\
개발협력 지원
\end{tabular} & $\begin{array}{l}\text { 개도국 정보통신방송 } \\
\text { 정책자문 (파라과이) }\end{array}$ & 개발컨설팅 & 2.00 & 2.00 & 신규 & '18 & 양자무상 & 9 \\
\hline & $\begin{array}{l}\text { 개도국 정보통신방송 } \\
\text { 개발협력 지원 }\end{array}$ & $\begin{array}{l}\text { 개도국 정보통신방송 } \\
\text { 정책자문 (페루) }\end{array}$ & 개발컨설팅 & 2.00 & 2.00 & 신규 & '18 & 장잠상 & 9 \\
\hline & $\begin{array}{l}\text { 개도국 정보통신방송 } \\
\text { 개발협력 지원 }\end{array}$ & $\begin{array}{l}\text { 개도국 방송환경 개선 } \\
\text { 지원(몽골) }\end{array}$ & 프로젝트 & 5.50 & 4.50 & 신규 & '18 '20 & 양자무상 & 9 \\
\hline & \begin{tabular}{|l|} 
개도국 정보통신방송 \\
개발협력 지원
\end{tabular} & $\begin{array}{l}\text { 개도국 방송환경 개 } \\
\text { 선지원(에티오피아) }\end{array}$ & 프로젝트 & 5.50 & 4.50 & 신규 & '18 '20 & 양자무상 & 9 \\
\hline & $\begin{array}{l}\text { 개도국 정보통신방송 } \\
\text { 개발협력 지원 }\end{array}$ & $\begin{array}{l}\text { 개도국 방송환경 개 } \\
\text { 선지원(콜봄비아) }\end{array}$ & 로젝트 & 5.50 & 4.50 & 신규 & '18 '20 & 양자무상 & 9 \\
\hline & $\begin{array}{l}\text { 개도국 정보통신방송 } \\
\text { 개발협력 지원 }\end{array}$ & $\begin{array}{l}\text { 개도국 방송환경 개 } \\
\text { 선지원(파키스탄) }\end{array}$ & 르제타 & 50 & 50 & 신규 & '18 '20 & 양자무상 & 9 \\
\hline & $\begin{array}{l}\text { 개도국 정보통신방송 } \\
\text { 개발협력 지원 }\end{array}$ & $\begin{array}{l}\text { 개도국 방송환경 개 } \\
\text { 선지원(베트남) }\end{array}$ & 프로젝트 & 4.72 & 1.00 & 계속 & -18 & 양자무상 & 9 \\
\hline & $\begin{array}{l}\text { 개도국 정보통신방송 } \\
\text { 개발협력 지원 }\end{array}$ & k-lab 설치 및 운영 & 프로젝트 & 24.10 & 4.65 & 계속 & '16 '20 & 양자무상 & 9 \\
\hline & $\begin{array}{l}\text { 개도국 정보통신방송 } \\
\text { 개발협력 지원 }\end{array}$ & $\begin{array}{l}\text { 세계은행협력사업(다 } \\
\text { 국가) }\end{array}$ & 프로젝트 & .4 & 39 & 계속 & $13 \sim ' 18$ & 다자성양자 & 9 \\
\hline & $\begin{array}{l}\text { 개도국 정보통신방송 } \\
\text { 개발협력 지원 }\end{array}$ & $\begin{array}{l}\text { 미주개발은행협력사업 } \\
\text { (다국가) }\end{array}$ & 프로젝트 & 10.94 & 3.80 & 계속 & $13 \sim ' 18$ & 다자성양자 & 9 \\
\hline & $\begin{array}{l}\text { 개도국 정보이용 환 } \\
\text { 경개선 }\end{array}$ & $\begin{array}{l}\text { 개도국 정보접근센터 } \\
\text { 구축 및 운영(엘살바 } \\
\text { 도르) }\end{array}$ & 멕트 & 5.85 & 5.85 & 신규 & '18 & 양자무상 & 4 \\
\hline & $\begin{array}{l}\text { 개도국 정보이용 환 } \\
\text { 경개선 }\end{array}$ & $\begin{array}{l}\text { 개도국 정보접근센터 } \\
\text { 구축 및 운영(말라위) }\end{array}$ & 프로젝트 & 35 & 85 & 신규 & '18 & 상 & 4 \\
\hline & \begin{tabular}{|l|} 
개도국 정보이용 환 \\
경개선
\end{tabular} & $\begin{array}{l}\text { 개도국정보접근센터구 } \\
\text { 축및운영 } \\
\text { (1차유지보수,베트남) }\end{array}$ & 프로젝트 & 2.55 & 2.55 & 신규 & '18 & 양자무상 & 4 \\
\hline
\end{tabular}




\begin{tabular}{|c|c|c|c|c|c|c|c|c|c|}
\hline & 세부사업명 & 내역사업명 & 사업 유형 & $\begin{array}{c}\text { 총사업 예산 } \\
\text { (억원) }\end{array}$ & $\begin{array}{l}\text { '18년예산 } \\
\text { (억원) }\end{array}$ & $\begin{array}{l}\text { 신규/ } \\
\text { 계속 }\end{array}$ & $\begin{array}{l}\text { 총사업 } \\
\text { 기간 }\end{array}$ & \begin{tabular}{|c|} 
구분 \\
(양-다자)
\end{tabular} & $\begin{array}{l}\text { SDGS } \\
\text { 목표 }\end{array}$ \\
\hline 41 & $\begin{array}{l}\text { 개도국 정보이용 환 } \\
\text { 경개선 }\end{array}$ & $\begin{array}{l}\text { 개도국 정보접근센터 } \\
\text { 구축 및 웇영(1차 } \\
\text { 유지보수, 콜롬비아) }\end{array}$ & 프로젝트 & 2.55 & 2.55 & 신규 & '18 & 양자무상 & 4 \\
\hline 42 & $\begin{array}{l}\text { 개도국 정보이용 환 } \\
\text { 경개선 }\end{array}$ & $\begin{array}{l}\text { 개도국정보접근센터구 } \\
\text { 축및운영 } \\
\text { (2차유지보수, 방글라 } \\
\text { 데시) }\end{array}$ & 프로젝트 & 2.55 & 2.55 & 신규 & '18 & 양자무상 & 9 \\
\hline 43 & $\begin{array}{l}\text { 개도국 정보이용 환 } \\
\text { 경개선 }\end{array}$ & \begin{tabular}{|l|} 
개도국정보접근센터구 \\
축및운영 \\
(2차유지보수,아제르 \\
바이잔)
\end{tabular} & 프로젝트 & 2.55 & 2.55 & 신규 & '18 & 양자무상 & 4 \\
\hline 44 & $\begin{array}{l}\text { 개도국 정보이용 환 } \\
\text { 경개선 }\end{array}$ & $\begin{array}{l}\text { 해외IT정책결정자 협 } \\
\text { 력채널 운영 }\end{array}$ & 기타기술협력 & 5.28 & 5.28 & 신규 & '18 & 양자무상 & 4 \\
\hline & $\begin{array}{l}\text { 국제기구를 통한 정 } \\
\text { 보화분야 해외진출지 } \\
\text { 원 }\end{array}$ & $\begin{array}{l}\text { 국제기구를 통한 정보 } \\
\text { 화분야 해외진출지원 }\end{array}$ & 기타기술협력 & 3.20 & 3.20 & 신규 & '18 & 양자무상 & 9 \\
\hline & $\begin{array}{l}\text { KIST 개도국 초청연 } \\
\text { 수 }\end{array}$ & $\begin{array}{l}\text { KIST 개도국 초청연 } \\
\text { 수 }\end{array}$ & 연수사업 & 0.60 & 0.60 & 신규 & '18 & 양자무상 & 9 \\
\hline 47 & $\begin{array}{l}\text { 한국표준과학연구원 } \\
\text { 연구운영비지원 }\end{array}$ & 측정인재개발 & 연수사업 & 0.30 & 0.30 & 신규 & '18 & 양자무상 & 9 \\
\hline & \begin{tabular}{|l|} 
광주과학기술원 연구 \\
운영비 지원
\end{tabular} & $\begin{array}{l}\text { 국제환경연구소 개도 } \\
\text { 국 지원 프로그램 }\end{array}$ & 연수사업 & 1.00 & 1.00 & 신규 & '18 & 양자무상 & 6 \\
\hline & $\begin{array}{l}\text { 개도국 과학기술 부 } \\
\text { 담금 }\end{array}$ & 한-UNDP 협력사업 & 기타 & 46.00 & 9.80 & 계속 & '16 ’20 & 다자성양자 & 17 \\
\hline 50 & $\begin{array}{l}\text { IAEA 기술협력부담 } \\
\text { 금 }\end{array}$ & $\begin{array}{l}\text { IAEA 기술협력부담 } \\
\text { 금 }\end{array}$ & & & 3.00 & 계속 & '91 계속 & 다자 & \\
\hline 51 & 우정사업해외활동 & 국제기구분담금 & & & 3.09 & 계속 & '18 계속 & 다자 & \\
\hline 52 & $\begin{array}{l}\text { 개도국 과학기술 부 } \\
\text { 담금 }\end{array}$ & $\begin{array}{l}\text { UN ESCAP APCTT } \\
\text { 부담금 }\end{array}$ & 기타 & & 0.40 & 계속 & ’06 계속 & 다자성양자 & 9 \\
\hline & 국제기구부담금 & ITU 부담금 & & & 7.26 & 계속 & 06 계속 & 다자 & \\
\hline 54 & $\begin{array}{l}\text { UN ESCAP ICT 개 } \\
\text { 발센터 운영지원 }\end{array}$ & $\begin{array}{l}\text { UN ESCAP ICT 개 } \\
\text { 발센터 운영지원 }\end{array}$ & 기타 & & 8.28 & 계속 & ’06 계속 & 다자성양자 & 9 \\
\hline
\end{tabular}




\section{외교부 2018년도 ODA 예산 계획[안]}

$\square$ 총괄

(단위: 억원)

\begin{tabular}{l|c|c|c||c|c|c}
\hline \multirow{2}{*}{ ODA 시행부처(기관) } & \multicolumn{3}{|c||}{2017} & \multicolumn{3}{c}{2018 (요구) } \\
\cline { 2 - 7 } & 양자 무상 & 다자 & 합계 & 양자 무상 & 다자 & 합계 \\
\hline $\begin{array}{l}\text { 외교부 } \\
\text { (KOICA 포함) }\end{array}$ & $8,387.2$ & 931.3 & $9,318.4$ & $10,780.5$ & $1,146.8$ & $11,927.3$ \\
\hline
\end{tabular}

※ 다자성양자는 양자에 포함

○'18년도 ODA 시행목표

- 지속가능한 개발목표(SDGs) 이행

- 통합적 $\mathrm{ODA}$ 및 내실있는 $\mathrm{ODA}$ 를 통한 개발협력 효과성 제고

으주요 정책과제

- 제2기 중점협력국 국가협력전략(CPS)에 기반한 사업 발굴 및 추진

- 인도적 지원 확대 및 국제질병퇴치기금의 내실있는 추진

- 글로벌파트너십 및 민관파트너쉽 강화

- 청년취업 기여 및 국제개발협력 인재 양성

\section{유형별 분류}

(억원, \%)

\begin{tabular}{|c|c|c|c|c|c|c|c|c|c|c|c|c|}
\hline \multirow[b]{2}{*}{ 구분 } & \multirow[b]{2}{*}{ 계 } & \multirow[b]{2}{*}{$\begin{array}{l}\text { 프로 } \\
\text { 젝트 }\end{array}$} & \multirow[b]{2}{*}{$\begin{array}{l}\text { 프로 } \\
\text { 르램 }\end{array}$} & \multirow[b]{2}{*}{$\begin{array}{l}\text { 개발 } \\
\text { 컨설팅 }\end{array}$} & \multicolumn{4}{|c|}{ 기술협력 } & \multirow{2}{*}{$\begin{array}{c}\text { 민관 } \\
\text { 협력 } \\
\text { (NGO, } \\
\text { 기업) }\end{array}$} & \multirow[b]{2}{*}{$\begin{array}{l}\text { 행정 } \\
\text { 비용 }\end{array}$} & \multirow[b]{2}{*}{ 기타 } & \multirow[b]{2}{*}{$\begin{array}{l}\text { 순수 } \\
\text { 다자** }\end{array}$} \\
\hline & & & & & $\begin{array}{l}\text { 연수 } \\
\text { 사업 }\end{array}$ & $\begin{array}{l}\text { 장항 } \\
\text { 지원 }\end{array}$ & $\begin{array}{l}\text { 봉사단 } \\
\text { 파견 }\end{array}$ & $\begin{array}{l}\text { 기타 } \\
\text { 기술 } \\
\text { 협력 }\end{array}$ & & & & \\
\hline \multirow{2}{*}{ '17년 } & $9,318.4$ & $2,928.3$ & 669.6 & 519.0 & 324.2 & 182.7 & $1,308.6$ & 3.5 & 597.8 & 113.6 & $1,881.7$ & 789.4 \\
\hline & 100 & 31.4 & 7.2 & 5.6 & 3.5 & 2.0 & 14.0 & 0.0 & 6.4 & 1.2 & 20.2 & 8.5 \\
\hline '18년 & 11927.3 & $3,930.7$ & $1,098.7$ & 514.2 & 362.2 & 182.3 & $1,626.4$ & 5.4 & 676.5 & 40.2 & $2,344.1$ & 1146.8 \\
\hline (요구) & 100 & 33.0 & 9.2 & 4.3 & 3.0 & 1.5 & 13.6 & 0.0 & 5.7 & 0.3 & 19.7 & 9.6 \\
\hline
\end{tabular}

* 다자성양자를 제외한 순수다자만 해당되며, 다자성양자는 사업 유형에 맞게 분류

$\square$ 총 사업 목록

\begin{tabular}{|c|c|c|c|c|c|c|c|c|c|}
\hline & 세부사업명 & 내역사업명 & 사업 유형 & $\begin{array}{c}\text { 총사업예산 } \\
\text { (억원) }\end{array}$ & $\begin{array}{l}\text { '18년예 } \\
\text { 산 (억원) }\end{array}$ & $\begin{array}{l}\text { 신규/ } \\
\text { 계속 }\end{array}$ & $\begin{array}{l}\text { 총사업 } \\
\text { 기간 }\end{array}$ & $\begin{array}{c}\text { 구분 } \\
\text { (양.다자 } \\
\text { ) }\end{array}$ & $\begin{array}{l}\text { SDGS } \\
\text { 목표 }\end{array}$ \\
\hline 1 & 기타 의무분담금 납부 & $\begin{array}{l}\text { 유엔교육과학문화기구 } \\
\text { 의무분담금 }\end{array}$ & & & 46.52 & 계속 & 1950-계속 & 다자 & \\
\hline 2 & 기타 의무분담금 납부 & $\begin{array}{l}\text { 중앙아시아국제학술연 } \\
\text { 구소 분담금 }\end{array}$ & 기타기술협력 & & 0.78 & 계속 & 1996-계속 & 다자성양자 & 4 \\
\hline 3 & $\begin{array}{l}\text { 국제기구 사업분담금 } \\
\text { 납부 }\end{array}$ & $\begin{array}{l}\text { 한-유엔 중남미카리브 } \\
\text { 경제위원회 협력기금 }\end{array}$ & 기타기술협력 & & 4.60 & 계속 & $2007 \sim 2018$ & 다자성양자 & 8 \\
\hline 4 & $\begin{array}{l}\text { 국제기구 사업분담금 } \\
\text { 납부 }\end{array}$ & 한-미주기구 협력기금 & 프로그램 & & 3.45 & 계속 & $2002 \sim 2018$ & 다자성양자 & 16 \\
\hline
\end{tabular}




\begin{tabular}{|c|c|c|c|c|c|c|c|c|c|}
\hline & 세부사업명 & 내역사업명 & 사업 유형 & $\begin{array}{c}\text { 총사업예산 } \\
\text { (억원) }\end{array}$ & $\begin{array}{l}\text { ‘18년예 } \\
\text { 산 (억원) }\end{array}$ & $\begin{array}{l}\text { 신규/ } \\
\text { 계속 }\end{array}$ & $\begin{array}{l}\text { 총사업 } \\
\text { 기간 }\end{array}$ & $\begin{array}{c}\text { 구분 } \\
\text { (양-다자 } \\
\text { ) }\end{array}$ & $\begin{array}{l}\mathrm{SDGS} \\
\text { 목표 }\end{array}$ \\
\hline 5 & $\begin{array}{l}\text { 국제기구 사업분담금 } \\
\text { 납부 }\end{array}$ & 한-ASEAN 협력기금 & 프로그램 & & 83.95 & 계속 & & 다자성양자 & 4 \\
\hline 6 & $\begin{array}{l}\text { 국제기구 사업분담금 } \\
\text { 납부 }\end{array}$ & 한-메콩 협력기금 & 프로젝트 & & 23.00 & 계속 & & 다자성양자 & 6 \\
\hline 7 & $\begin{array}{l}\text { 국제기구 사업분담금 } \\
\text { 납부 }\end{array}$ & 한-ASEAN 센터 & 기타 & & 76.00 & 계속 & & 다자성양자 & 17 \\
\hline 8 & $\begin{array}{l}\text { 국제기구 사업분담금 } \\
\text { 납부 }\end{array}$ & $\begin{array}{l}\text { 중동담수화 연구소 협 } \\
\text { 력기금 }\end{array}$ & 기타 & 44.62 & 2.30 & 계속 & 2011 & 다자성양자 & 6 \\
\hline 9 & $\begin{array}{l}\text { 국제기구 사업분담금 } \\
\text { 납부 }\end{array}$ & $\begin{array}{l}\text { 크메르루즈 전범재판 } \\
\text { 소(ECCC) 사업분담금 }\end{array}$ & 프로그램 & & 5.75 & 계속 & 2006-계속 & 다자성양자 & 16 \\
\hline 10 & $\begin{array}{l}\text { 국제기구 사업분담금 } \\
\text { 납부 }\end{array}$ & 한-ESCAP 협력 기금 & 프로그램 & 9.20 & 9.20 & 계속 & 1987 계속 & 다자성양자 & 17 \\
\hline 11 & $\begin{array}{l}\text { 국제기구 사업분담금 } \\
\text { 납부 }\end{array}$ & $\begin{array}{l}\text { ESCAP TCDC 자문관 } \\
\text { 파견 }\end{array}$ & 기타기술협력 & 0.06 & 0.06 & 계속 & 2003 계속 & 다자성양자 & 17 \\
\hline 12 & $\begin{array}{l}\text { 국제기구 사업분담금 } \\
\text { 납부 }\end{array}$ & $\begin{array}{l}\text { 한-아세안 FTA 경제 } \\
\text { 협력기금 }\end{array}$ & 프로그램 & 5.75 & 5.75 & 계속 & 2008 계속 & 다자성양자 & 17 \\
\hline 13 & 기타 의무분담금 납부 & $\begin{array}{l}\mathrm{OECD} \text { 개발센터 의무 } \\
\text { 분담금 }\end{array}$ & & 4.37 & 4.37 & 계속 & 1991 계속 & 다자 & \\
\hline 14 & $\begin{array}{l}\text { 국제기구 사업분담금 } \\
\text { 납부 } \\
\end{array}$ & $\begin{array}{l}\text { 글로벌녹색성장연구소 } \\
\text { (GGGI)자발적 기여금 }\end{array}$ & & & 115.00 & 계속 & 2013 & 다자 & \\
\hline 15 & 기타 의무분담금 납부 & $\begin{array}{l}\text { 유엔사막화방지협약 } \\
\text { 분담금 }\end{array}$ & & & 2.07 & 계속 & 1999 & 다자 & \\
\hline 16 & $\begin{array}{l}\text { 국제기구 사업분담금 } \\
\text { 납부 }\end{array}$ & 유엔아동기금 & & 69.00 & 69.00 & 계속 & 1988-계속 & 다자 & \\
\hline 17 & $\begin{array}{l}\text { 국제기구 사업분담금 } \\
\text { 납부 }\end{array}$ & 유엔난민기구 & & 51.75 & 51.75 & 계속 & 1988-계속 & 다자 & \\
\hline 18 & $\begin{array}{l}\text { 국제기구 사업분담금 } \\
\text { 납부 }\end{array}$ & $\begin{array}{l}\text { 유엔인권최고대표사무 } \\
\text { 소 }\end{array}$ & & 19.55 & 12.51 & 계속 & 1994-계속 & 다자 & \\
\hline 19 & $\begin{array}{l}\text { 국제기구 사업분담금 } \\
\text { 납부 }\end{array}$ & 유엔마약범죄사무소 & & 4.76 & 4.76 & 계속 & 1994-계속 & 다자 & \\
\hline 20 & 기타 의무분담금 납부 & $\begin{array}{l}\text { 국제이주기구(IOM) 의 } \\
\text { 무분담금 }\end{array}$ & & 13.94 & 13.94 & 계속 & 1988 -계속 & 다자 & \\
\hline 21 & $\begin{array}{l}\text { 국제기구 사업분담금 } \\
\text { 납부 }\end{array}$ & $\begin{array}{l}\text { 유럽안보협력기구 } \\
\text { (OSCE)파트너십 }\end{array}$ & & & 1.91 & 계속 & 2009 & 다자 & \\
\hline 22 & $\begin{array}{l}\text { 국제기구 사업분담금 } \\
\text { 납부 }\end{array}$ & $\begin{array}{l}\text { 소말리아 해적퇴치 연 } \\
\text { 락그륩 (CGPCS) 신탁 } \\
\text { 기금 }\end{array}$ & 프로젝트 & & 2.30 & 계속 & 2013 & 다자성양자 & 16 \\
\hline 23 & $\begin{array}{l}\text { 국제기구 사업분담금 } \\
\text { 납부 }\end{array}$ & $\begin{array}{l}\text { 세계무역기구 개도국 } \\
\text { 협력사업기여금(GTF) }\end{array}$ & & & 3.99 & 계속 & $\begin{array}{c}2002-\text { 계속( } \\
\text { 개도국지원 } \\
\text { 사업으로총 } \\
\text { 사업기간미 } \\
\text { 정 })\end{array}$ & 다자 & \\
\hline 24 & $\begin{array}{l}\text { 국제기구 사업분담금 } \\
\text { 납부 }\end{array}$ & $\begin{array}{l}\text { 국제원자력기구(IAEA) } \\
\text { 회원국으로서 기술협 } \\
\text { 력기금(TCF) 납부 의 } \\
\text { 무 이행 }\end{array}$ & & & 30.66 & 계속 & 1957-계속 & 다자 & \\
\hline 25 & 기타 의무분담금 납부 & $\begin{array}{l}\text { 국제원자력기구(IAEA) } \\
\text { 회원국으로서 정규분 } \\
\text { 담금 납부 의무 이행 }\end{array}$ & & & 22.12 & 계속 & & 다자 & \\
\hline 26 & 민관협력사업(ODA) & $\begin{array}{l}\text { 민간단체의 국제개발 } \\
\text { 협력사업 지원 }\end{array}$ & 민관협력 & & 330.00 & 계속 & 1995년 & 양자무상 & 17 \\
\hline 27 & $\begin{array}{l}\text { 국제기구 사업분담금 } \\
\text { 납부 }\end{array}$ & $\begin{array}{l}\text { 군축분야 인도적 지원 } \\
\text { 신탁기금 }\end{array}$ & 프로그램 & & 9.20 & 계속 & 1993년 & 다자성양자 & 16 \\
\hline 28 & $\begin{array}{l}\text { 국제기구 사업분담금 } \\
\text { 납부 }\end{array}$ & $\begin{array}{l}\text { 한-PIF(태평양도서국 } \\
\text { 포럼) 협력기금 }\end{array}$ & 프로젝트 & & 11.50 & 계속 & 2008-계속 & 다자성양자 & 14 \\
\hline 29 & $\mathrm{ODA}$ 선진화 & ODA 선진화 & 행정비용 & & 13.68 & 계속 & 2007 계속 & 양자무상 & \\
\hline 30 & $\begin{array}{l}\text { 국제기구 사업분담금 } \\
\text { 납부 }\end{array}$ & $\begin{array}{l}\mathrm{OECD} \mathrm{DAC} \mathrm{자발적} \\
\text { 기여금 }\end{array}$ & 기타 & & 11.50 & 계속 & 2011-계속 & 다자성양자 & 17 \\
\hline 31 & 기타 의무분담금 납부 & $\begin{array}{l}\text { 국제원조투명성기구 } \\
\text { (IATI) }\end{array}$ & 기타 & & 0.99 & 계속 & 2016-계속 & 다자성양자 & 17 \\
\hline
\end{tabular}




\begin{tabular}{|c|c|c|c|c|c|c|c|c|c|}
\hline & 세부사업명 & 내역사업명 & 사업 유형 & $\begin{array}{c}\text { 총사업예산 } \\
\text { (억원) }\end{array}$ & $\begin{array}{l}\text { '18년예 } \\
\text { 산 (억원) }\end{array}$ & $\begin{array}{l}\text { 신규/ } \\
\text { 계속 }\end{array}$ & $\begin{array}{l}\text { 총사업 } \\
\text { 기간 }\end{array}$ & $\begin{array}{c}\text { 구분 } \\
\text { (양·다자 } \\
\text { ) }\end{array}$ & $\begin{array}{l}\text { SDGS } \\
\text { 목표 }\end{array}$ \\
\hline 32 & $\begin{array}{l}\text { 유엔 정규예산분담금 } \\
\text { 납부 }\end{array}$ & 유엔 정규예산 분담금 & & & 123.24 & 계속 & $1991 \sim$ & 다자 & \\
\hline 33 & \begin{tabular}{|l} 
유엔 PKO예산분담금 \\
납부
\end{tabular} & $\begin{array}{l}\text { 유엔 평화유지활동 } \\
(\mathrm{PKO}) \text { 예산 분담금 }\end{array}$ & & & 139.03 & 계속 & $1991 \sim$ & 다자 & \\
\hline 34 & $\begin{array}{l}\text { 국제기구 사업분담금 } \\
\text { 납부 }\end{array}$ & $\begin{array}{l}\text { 유엔 팔레스타인 난민 } \\
\text { 구호기구 }\end{array}$ & & & 11.50 & 계속 & 1999-계속 & 다자 & \\
\hline 35 & $\begin{array}{l}\text { 국제기구 사업분담금 } \\
\text { 납부 }\end{array}$ & 유엔 평화구축기금 & & & 40.94 & 계속 & $2009 \sim$ & 다자 & \\
\hline 36 & $\begin{array}{l}\text { 국제기구 사업분담금 } \\
\text { 납부 }\end{array}$ & 유엔자원봉사단 & & & 50.03 & 계속 & 1990-계속 & 다자 & \\
\hline 37 & $\begin{array}{l}\text { 국제기구 사업분담금 } \\
\text { 납부 }\end{array}$ & $\begin{array}{l}\text { 유엔 정무국 분쟁예방 } \\
\text { 기금 }\end{array}$ & & & 34.50 & 계속 & 2015-계속 & 다자 & \\
\hline 38 & $\begin{array}{l}\text { 국제기구 사업분담금 } \\
\text { 납부 } \\
\end{array}$ & $\begin{array}{l}\text { 유엔아프리카경제위원 } \\
\text { 회 협력기금 }\end{array}$ & & & 4.03 & 신규 & 2017-계속 & 다자 & \\
\hline 39 & $\begin{array}{l}\text { 국제기구 사업분담금 } \\
\text { 납부 }\end{array}$ & 한-UNDP 신탁기금 & 프로젝트 & & 1.98 & 계속 & 1995-계속 & 다자성양자 & 5 \\
\hline 40 & $\begin{array}{l}\text { 국제기구초급전문가 } \\
\text { 파견 등 국제기구진출 } \\
\text { 지원 }\end{array}$ & $\begin{array}{l}\text { 국제기구초급전문가 } \\
\text { 파견 }\end{array}$ & 프로젝트 & & 25.79 & 계속 & 1996-계속 & 다자성양자 & 4 \\
\hline 41 & 인도적지원(ODA) & 긴급구호 & 기타 & & 994.64 & 계속 & 계속 & 양자무상 & 13 \\
\hline 42 & 인도적지원(ODA) & $\begin{array}{l}\text { 선진인도적지원 역량 } \\
\text { 강화 }\end{array}$ & 기타 & & 1.86 & 계속 & 계속 & 양자무상 & 17 \\
\hline 43 & 인도적지원(ODA) & $\begin{array}{l}\text { 긴급구호 민관파트너 } \\
\text { 십 구축 }\end{array}$ & 민관협력 & & 31.20 & 계속 & 계속 & 양자무상 & 17 \\
\hline 44 & 기타 의무분담금 납부 & $\begin{array}{l}\text { 불어권국제기구(OIF) } \\
\text { 지원 }\end{array}$ & & & 0.14 & 신규 & 2017-계속 & 다자 & \\
\hline 45 & 기타 의무분담금 납부 & $\begin{array}{l}\text { 유엔공업개발기구 의 } \\
\text { 무분담금 }\end{array}$ & & & 32.34 & 계속 & 1967 - 계속 & 다자 & \\
\hline 46 & $\begin{array}{l}\text { 국제기구 사업분담금 } \\
\text { 납부 }\end{array}$ & $\mathrm{UNDP}$ 정규재원 기여금 & & & 115.00 & 계속 & 2010 - 계속 & 다자 & \\
\hline 47 & 기타 의무분담금 납부 & 콜롬보플랜 의무분담금 & & & 0.20 & 계속 & 1963 - 계속 & 다자 & \\
\hline 48 & $\begin{array}{l}\text { 국제기구 사업분담금 } \\
\text { 납부 }\end{array}$ & $\begin{array}{l}\text { UNIDO 공업개발기금 } \\
\text { (IDF) }\end{array}$ & 프로젝트 & & 5.75 & 계속 & 2006 - 계속 & 다자성양자 & 9 \\
\hline 49 & $\begin{array}{l}\text { 국제기구 사업분담금 } \\
\text { 납부 }\end{array}$ & $\begin{array}{l}\text { UNIDO 서울투자기술 } \\
\text { 진흥사무소(ITPO) }\end{array}$ & 기타 & & 4.20 & 계속 & 1987 - 계속 & 다자성양자 & 9 \\
\hline 50 & $\begin{array}{l}\text { 국제기구 사업분담금 } \\
\text { 납부 } \\
\end{array}$ & $\mathrm{WB}$ 여성 기금 & & 110 & 30 & 신규 & 2018 계속 & 다자 & \\
\hline 51 & $\begin{array}{l}\text { 국제기구 사업분담금 } \\
\text { 납부 }\end{array}$ & \begin{tabular}{|l|} 
한-UNDP 지속가능개 \\
발(SDG) 신탁기금
\end{tabular} & 프로젝트 & & 97.75 & 계속 & $2016-2020$ & 다자성양자 & 1 \\
\hline 52 & 기타 의무분담금 납부 & $\begin{array}{l}\text { 다자기구성과평가네트 } \\
\text { 워크 의무분담금 }\end{array}$ & 기타 & 5.40 & 1.41 & 계속 & $2016-2019$ & 다자성양자 & 17 \\
\hline 53 & 기타 의무분담금 납부 & $\begin{array}{l}\text { 아프가니스탄 경제사 } \\
\text { 회분야 지원사업 }\end{array}$ & 프로그램 & & 862.50 & 계속 & $2013-2020$ & 다자성양자 & 5 \\
\hline 54 & $\begin{array}{l}\text { 국제기구 사업분담금 } \\
\text { 납부 }\end{array}$ & $\begin{array}{l}\text { 한-아프리카연합(AU) } \\
\text { 협력기금 }\end{array}$ & 기타 & 11.50 & 46.00 & 계속 & 2017-계속 & 다자성양자 & 16 \\
\hline 55 & 민관협력국제질병퇴치 & $\begin{array}{l}\text { 세이브더칠드런 우간 } \\
\text { 다 모자보건 접근성 } \\
\text { 및 서비스 향상사업 }\end{array}$ & 민관협력 & 28.00 & 6.43 & 계속 & $2014-2018$ & 양자무상 & 3 \\
\hline 56 & 민관협력국제질병퇴치 & $\begin{array}{l}\text { 월드비전 우간다 동부 } \\
\text { 지역 모자보건 증진사 } \\
\text { 업 }\end{array}$ & 민관협력 & 38.43 & 7.84 & 계속 & $2014-2018$ & 양자무상 & 3 \\
\hline 57 & 민관협력국제질병퇴치 & $\begin{array}{l}\text { 굿네이버스 탄자니아 } \\
\text { 지역 보건인력 활용 } \\
\text { 모성건강 관리사업 }\end{array}$ & 민관협력 & 44.80 & 11.73 & 계속 & $2015-2018$ & 양자무상 & 3 \\
\hline 58 & 민관협력국제질병퇴치 & $\begin{array}{l}\text { 더멋진세상 세네갈 모 } \\
\text { 자보건 강화 및 환경 } \\
\text { 개선사업 }\end{array}$ & 민관협력 & 22.40 & 5.65 & 계속 & $2015-2018$ & 양자무상 & 3 \\
\hline 59 & 민관협력국제질병퇴치 & \begin{tabular}{|l|} 
플랜한국위원회 부르 \\
키나파소 HIV 유행 \\
및 모자수직감염 예방사업
\end{tabular} & 민관협력 & 22.40 & 7.59 & 계속 & $2016-2018$ & 양자무상 & 3 \\
\hline
\end{tabular}




\begin{tabular}{|c|c|c|c|c|c|c|c|c|c|}
\hline & 세부사업명 & 내역사업명 & 사업 유형 & $\begin{array}{c}\text { 총사업예산 } \\
\text { (억원) }\end{array}$ & $\begin{array}{l}\text { '18년 예 } \\
\text { 산 (억원) }\end{array}$ & $\begin{array}{l}\text { 신규/ } \\
\text { 계속 }\end{array}$ & $\begin{array}{l}\text { 총사업 } \\
\text { 기간 }\end{array}$ & $\begin{array}{c}\text { 구분 } \\
\text { (양-다자 } \\
\text { ) }\end{array}$ & $\begin{array}{l}\text { SDGs } \\
\text { 목표 }\end{array}$ \\
\hline 60 & 민관협력국제질병퇴치 & $\begin{array}{l}\text { 하트하트재단 말라위 } \\
\text { 중부지역 트라코마 퇴 } \\
\text { 치사업 }\end{array}$ & 민관협력 & 20.16 & 5.24 & 계속 & $2015-2018$ & 양자무상 & 3 \\
\hline 61 & 민관협력국제질병퇴치 & 사업개발비 & 기타 & & 2.21 & 신규 & - & 양자무상 & \\
\hline 62 & $\begin{array}{l}\text { 국제기구협력국제질병 } \\
\text { 퇴치 }\end{array}$ & $\begin{array}{l}\text { UNICEF 우간다 모자 } \\
\text { 보건 지원 강화사업 }\end{array}$ & 프로젝트 & 98.35 & 12.87 & 계속 & $2015-2018$ & 다자성양자 & 3 \\
\hline 63 & $\begin{array}{l}\text { 국제기구협력국제질병 } \\
\text { 퇴치 }\end{array}$ & $\begin{array}{l}\text { UNICEF 탄자니아 보 } \\
\text { 건서비스 제공 모자보 } \\
\text { 건사업 }\end{array}$ & 프로젝트 & 64.98 & 7.11 & 계속 & $2015-2018$ & 다자성양자 & 3 \\
\hline 64 & $\begin{array}{l}\text { 국제기구협력국제질병 } \\
\text { 퇴치 }\end{array}$ & $\begin{array}{l}\text { UNFPA 모잠비크 영 } \\
\text { 아 및 모성사망률 감 } \\
\text { 소사업 }\end{array}$ & 프로젝트 & 83.37 & 13.44 & 계속 & $2015-2018$ & 다자성양자 & 3 \\
\hline 65 & $\begin{array}{l}\text { 국제기구협력국제질병 } \\
\text { 퇴치 }\end{array}$ & $\begin{array}{l}\text { UNICEF 말라위 모자 } \\
\text { 보건 개선사업 }\end{array}$ & 프로젝트 & 51.75 & 11.01 & 계속 & $2016-2018$ & 다자성양자 & 3 \\
\hline 66 & $\begin{array}{l}\text { 국제기구협력국제질병 } \\
\text { 퇴치 }\end{array}$ & $\begin{array}{l}\text { UNFPA 탄자니아 모 } \\
\text { 자보건 시스템 강화사 } \\
\text { 업 }\end{array}$ & 프로젝트 & 51.75 & 20.78 & 계속 & $2016-2018$ & 다자성양자 & 3 \\
\hline 67 & $\begin{array}{l}\text { 국제기구협력국제질병 } \\
\text { 퇴치 }\end{array}$ & $\begin{array}{l}\text { UNFPA 우간다 소녀 } \\
\text { 의 보다 나은 삶을 위 } \\
\text { 한 십대임신 예방 및 } \\
\text { 사회경제적 역량강화 } \\
\text { 사업 }\end{array}$ & 프로젝트 & 57.50 & 10.83 & 계속 & $2016-2018$ & 다자성양자 & 3 \\
\hline 68 & $\begin{array}{l}\text { 국제기구협력국제질병 } \\
\text { 퇴치 }\end{array}$ & $\begin{array}{l}\text { IVI 모잠비크 콜레라 } \\
\text { 백신접종 사업 }\end{array}$ & 프로젝트 & 34.50 & 17.78 & 계속 & $2017-2019$ & 다자성양자 & 3 \\
\hline 69 & $\begin{array}{l}\text { 국제기구협력국제질병 } \\
\text { 퇴치 }\end{array}$ & $\begin{array}{l}\text { UNICEF 수단 난민의 } \\
\text { WASH 지원사업 }\end{array}$ & 프로젝트 & 34.50 & 5.91 & 계속 & $2016-2018$ & 다자성양자 & 6 \\
\hline 70 & $\begin{array}{l}\text { 국제기구협력국제질병 } \\
\text { 퇴치 }\end{array}$ & $\begin{array}{l}\text { WFP 아프리카 난민 } \\
\text { 의 식량안보 모니터링 } \\
\text { 시스템(mVAM) 구축 } \\
\text { 사업 }\end{array}$ & 프로젝트 & 69.00 & 30.85 & 계속 & $2016-2018$ & 다자성양자 & 2 \\
\hline 71 & $\begin{array}{l}\text { 국제기구협력국제질병 } \\
\text { 퇴치 }\end{array}$ & 사업개발비 & 기타 & & 1.60 & 신규 & - & 다자성양자 & \\
\hline 72 & 글로벌 국제질병퇴치 & $\begin{array}{l}\text { UNITAID 백신개발 및 } \\
\text { 보급을 통한 질병퇴치 } \\
\text { 활동 }\end{array}$ & & 265.42 & 46.41 & 계속 & $2013-2018$ & 다자 & \\
\hline 73 & 글로벌 국제질병퇴치 & $\begin{array}{l}\text { GAVI 백신개발 및 보 } \\
\text { 급을 통한 질병퇴치 } \\
\text { 활동 }\end{array}$ & & 200.40 & 46.41 & 계속 & $2013-2018$ & 다자 & \\
\hline 74 & 글로벌 국제질병퇴치 & $\begin{array}{l}\text { 글로벌펀드 백신개발 } \\
\text { 및 보급을 통한 질병 } \\
\text { 퇴치 활동 }\end{array}$ & & 155.60 & 46.41 & 계속 & $2013-2018$ & 다자 & \\
\hline 75 & 글로벌 국제질병퇴치 & $\begin{array}{l}\text { GPEI 소아마비퇴치 } \\
\text { 활동 }\end{array}$ & 프로그램 & 91.80 & 46.41 & 계속 & $2016-2018$ & 다자성양자 & 17 \\
\hline 76 & 글로벌 국제질병퇴치 & $\begin{array}{l}\text { UNICEF 혁신센터 혁 } \\
\text { 신적 사업방식 확산을 } \\
\text { 통한 질병퇴치활동 } \\
\end{array}$ & 프로그램 & 11.18 & 3.30 & 계속 & $2015-2018$ & 다자성양자 & 17 \\
\hline 77 & 글로벌 국제질병퇴치 & \begin{tabular}{|l|} 
감염병 퇴치기구 지원 \\
질병퇴치활동
\end{tabular} & & 48.06 & 48.06 & 신규 & 2018 & 다자 & \\
\hline 78 & 기금운영비 & 기금운영비 & 기타 & & 28.65 & 계속 & & 양자무상 & \\
\hline 79 & 베트남(ODA) & $\begin{array}{l}\text { 베트남 한베 친선 IT } \\
\text { 대학 4년제 승격지원 } \\
\text { 사업 }\end{array}$ & 프로젝트 & 58.76 & 6.20 & 계속 & $2013-2019$ & 양자무상 & 4 \\
\hline 80 & 베트남(ODA) & $\begin{array}{l}\text { 베트남 한베 과학기술 } \\
\text { 연구원(V-KIST)설립지 } \\
\text { 원 사업 }\end{array}$ & 프로젝트 & 392.00 & 20.00 & 계속 & $2014-2018$ & 양자무상 & 4 \\
\hline 81 & 베트남(ODA) & $\begin{array}{l}\text { 베트남 한베 산업기술 } \\
\text { 대학 } 3 \text { 차지원사업 }\end{array}$ & 프로젝트 & 67.20 & - & 계속 & $2014-2018$ & 양자무상 & 4 \\
\hline 82 & 베트남(ODA) & $\begin{array}{l}\text { 베트남 꽝찌성 행복프 } \\
\text { 로그램 }\end{array}$ & 프로젝트 & 108.30 & 20.66 & 계속 & $2014-2018$ & 양자무상 & 1 \\
\hline 83 & 베트남(ODA) & $\begin{array}{l}\text { 베트남 라오까이성 행 } \\
\text { 복프로그램 }\end{array}$ & 프로젝트 & 156.80 & 55.04 & 계속 & $2014-2018$ & 양자무상 & 1 \\
\hline
\end{tabular}




\begin{tabular}{|c|c|c|c|c|c|c|c|c|c|}
\hline & 세부사업명 & 내역사업명 & 사업 유형 & $\begin{array}{c}\text { 총사업예산 } \\
\text { (억원) }\end{array}$ & $\begin{array}{l}\text { '18년 예 } \\
\text { 산 (억원) }\end{array}$ & $\begin{array}{l}\text { 신규/ } \\
\text { 계속 }\end{array}$ & $\begin{array}{l}\text { 총사업 } \\
\text { 기간 }\end{array}$ & $\begin{array}{c}\text { 구분 } \\
\text { (양-다자 } \\
\text { ) }\end{array}$ & $\begin{array}{l}\mathrm{SDGS} \\
\text { 목표 }\end{array}$ \\
\hline 84 & 베트남(ODA) & $\begin{array}{l}\text { 베트남 지뢰 및 불발 } \\
\text { 탄 통합대응 역량강화 } \\
\text { 사업 }\end{array}$ & 프로젝트 & 228.00 & 7.30 & 계속 & $2016-2020$ & 양자무상 & 11 \\
\hline 85 & 베트남(ODA) & $\begin{array}{l}\text { 베트남 지가산정 역량 } \\
\text { 강화 및 지가정보시스 } \\
\text { 템 개선사업 }\end{array}$ & 프로젝트 & 102.60 & 49.08 & 계속 & $2016-2018$ & 양자무상 & 11 \\
\hline 86 & 베트남(ODA) & $\begin{array}{l}\text { 베트남 폭력피해 여성 } \\
\text { 및 여아 예방 보호 모 } \\
\text { 델 구축사업 }\end{array}$ & 프로젝트 & 28.50 & 24.88 & 계속 & $2016-2018$ & 양자무상 & 5 \\
\hline 87 & 베트남(ODA) & $\begin{array}{l}\text { 베트남 향강종합개발 } \\
\text { 지원사업 }\end{array}$ & 개발컨설팅 & 67.20 & - & 계속 & $2014-2018$ & 양자무상 & 11 \\
\hline 88 & 베트남(ODA) & $\begin{array}{l}\text { 베트남 고속도로 관리 } \\
\text { 및 제도 역량강화 사 } \\
\text { 업 }\end{array}$ & 개발컨설팅 & 15.45 & 9.95 & 계속 & $2014-2018$ & 양자무상 & 9 \\
\hline 89 & 베트남(ODA) & $\begin{array}{l}\text { 베트남 그린시티 도시 } \\
\text { 계획 의사결정시스템 } \\
\text { 구축사업 }\end{array}$ & 개발컨설팅 & 66.95 & 2.50 & 계속 & $2015-2018$ & 양자무상 & 11 \\
\hline 90 & 베트남(ODA) & $\begin{array}{l}\text { 베트남 미래비전 } \\
\mathrm{DEEP} \text { 사업 }\end{array}$ & 개발컨설팅 & 22.88 & 5.51 & 계속 & $2015-2018$ & 양자무상 & 16 \\
\hline 91 & 베트남(ODA) & \begin{tabular}{|l} 
베트남 중부지역병원 \\
사후관리 기술협력 \\
(Q-health)사업
\end{tabular} & 개발컨설팅 & 41.20 & 25.35 & 계속 & $2015-2018$ & 양자무상 & 3 \\
\hline 92 & 베트남(ODA) & $\begin{array}{l}\text { 베트남 교통분야 } \\
\text { DEEP사업 }\end{array}$ & 개발컨설팅 & 51.50 & 12.00 & 계속 & $2015-2019$ & 양자무상 & 9 \\
\hline 93 & 베트남(ODA) & $\begin{array}{l}\text { 베트남 산업계 대상 } \\
\text { 에너지 효율화사업 }\end{array}$ & 개발컨설팅 & 23.00 & 21.00 & 계속 & $2017-2019$ & 양자무상 & 7 \\
\hline 94 & 베트남(ODA) & $\begin{array}{l}\text { 베트남 하노이 도시철 } \\
\text { 도 8호선 건설 타당성 } \\
\text { 조사사업 } \\
\end{array}$ & 개발컨설팅 & 69.00 & 41.00 & 신규 & $2017-2020$ & 양자무상 & 11 \\
\hline 95 & 베트남(ODA) & $\begin{array}{c}\text { 베트남 민간부문 투 } \\
\text { 자활성화를 위한 투자 } \\
\text { 정보시스템 구축사업 } \\
\end{array}$ & 프로젝트 & 63.25 & 1.00 & 신규 & $2018-2021$ & 양자무상 & 8 \\
\hline 96 & 베트남(ODA) & $\begin{array}{l}\text { 베트남 사회주택 공급 } \\
\text { 확대를 위한 마스터플 } \\
\text { 랜 및 개발전략 수립 } \\
\text { 사업 }\end{array}$ & 개발컨설팅 & 34.50 & 1.00 & 신규 & $2018-2020$ & 양자무상 & 11 \\
\hline 97 & 베트남(ODA) & $\begin{array}{l}\text { 베트남 연안관리 및 } \\
\text { 해양오염 대응 이행전 } \\
\text { 략 수립사업 }\end{array}$ & 프로젝트 & 34.50 & 2.00 & 신규 & $2018-2020$ & 양자무상 & 14 \\
\hline 98 & 인도네시아(ODA) & $\begin{array}{l}\text { 인도네시아 자카르타 } \\
\text { 수도권해안종합개발 } \\
\text { 컨설팅사업 }\end{array}$ & 개발컨설팅 & 106.40 & 42.56 & 계속 & $2014-2019$ & 양자무상 & 11 \\
\hline 99 & 인도네시아(ODA) & $\begin{array}{l}\text { 인도네시아 경찰청 사 } \\
\text { 이버범죄수사 역량강 } \\
\text { 화 사업 }\end{array}$ & 프로젝트 & 58.65 & 1.00 & 신규 & $2018-2021$ & 양자무상 & 16 \\
\hline 100 & 캄보디아(ODA) & $\begin{array}{l}\text { 캄보디아 국립소아병 } \\
\text { 원 기능개선사업 }\end{array}$ & 프로젝트 & 76.07 & 1.00 & 계속 & $2013-2018$ & 양자무상 & 1 \\
\hline 101 & 캄보디아(ODA) & $\begin{array}{l}\text { 캄보디아 민간항공 관 } \\
\text { 리역량 제고 및 교육 } \\
\text { 센터 건립사업 }\end{array}$ & 프로젝트 & 114.13 & 2.00 & 계속 & $2013-2018$ & 양자무상 & 1 \\
\hline 102 & 캄보디아(ODA) & $\begin{array}{l}\text { 캄보디아 농촌공동체 } \\
\text { 개발사업 }\end{array}$ & 프로젝트 & 100.43 & 15.00 & 계속 & $2014-2018$ & 양자무상 & 2 \\
\hline 103 & 캄보디아(ODA) & $\begin{array}{l}\text { 캄보디아 국가 지급결 } \\
\text { 제시스템 구축사업 }\end{array}$ & 프로젝트 & 82.40 & 30.00 & 계속 & $2015-2018$ & 양자무상 & 16 \\
\hline 104 & 캄보디아(ODA) & $\begin{array}{l}\text { 캄보디아 앙코르 유적 } \\
\text { 프레아피투사원 복원 } \\
\text { 정비 기초사업 }\end{array}$ & 개발컨설팅 & 41.20 & 15.00 & 계속 & $2015-2018$ & 양자무상 & 1 \\
\hline 105 & 캄보디아(ODA) & $\begin{array}{l}\text { 캄보디아 캄퐁참 국립 } \\
\text { 농업대학 교육 및 연 } \\
\text { 구개발 혁신 역량강화 } \\
\text { 사업 }\end{array}$ & 개발컨설팅 & 22.80 & 6.00 & 계속 & $2016-2018$ & 양자무상 & 4 \\
\hline
\end{tabular}




\begin{tabular}{|c|c|c|c|c|c|c|c|c|c|}
\hline & 세부사업명 & 내역사업명 & 사업 유형 & $\begin{array}{c}\text { 총사업예산 } \\
\text { (억원) }\end{array}$ & $\begin{array}{l}\text { ‘18년예 } \\
\text { 산 (억원) }\end{array}$ & $\begin{array}{l}\text { 신규/ } \\
\text { 계속 }\end{array}$ & $\begin{array}{l}\text { 총사업 } \\
\text { 기간 }\end{array}$ & $\begin{array}{c}\text { 구분 } \\
\text { (양-다자 } \\
\text { ) }\end{array}$ & $\begin{array}{l}\mathrm{SDGS} \\
\text { 목표 }\end{array}$ \\
\hline 106 & 캄보디아(ODA) & $\begin{array}{l}\text { 캄보디아 건강형평성 } \\
\text { 및 질 향상 프로그램 }\end{array}$ & 프로젝트 & 80.50 & 24.00 & 계속 & $2017-2019$ & 양자무상 & 3 \\
\hline 107 & 캄보디아(ODA) & \begin{tabular}{|l|} 
캄보디아 \\
KOICA-GHSA 로드맵 \\
수립 및 3대 행동계획 \\
이행지원 사업
\end{tabular} & 프로젝트 & 34.50 & 9.40 & 계속 & $2017-2019$ & 양자무상 & 3 \\
\hline 108 & 캄보디아(ODA) & $\begin{array}{l}\text { 캄보디아 앙두엉병원 } \\
\text { 이비인후과(ENT) 역 } \\
\text { 량강화사업 }\end{array}$ & 프로젝트 & 92.00 & 1.00 & 신규 & $2018-2021$ & 양자무상 & 3 \\
\hline 109 & 필리핀(ODA) & $\begin{array}{l}\text { 필리핀 통합의료정보 } \\
\text { 체계 구축사업 }\end{array}$ & 프로젝트 & 56.00 & 1.00 & 계속 & $2014-2018$ & 양자무상 & 3 \\
\hline 110 & 필리핀(ODA) & $\begin{array}{l}\text { 필리핀메트로마닐라홍 } \\
\text { 수조기경보및모니터링 } \\
\text { 체계구축사업 }\end{array}$ & 프로젝트 & 53.56 & 23.00 & 계속 & $2015-2018$ & 양자무상 & 13 \\
\hline 111 & 필리핀(ODA) & $\begin{array}{l}\text { 필리핀 파나이섬 고지 } \\
\text { 대 농촌종합개발사업 }\end{array}$ & 프로젝트 & 66.95 & 20.00 & 계속 & $2015-2019$ & 양자무상 & 2 \\
\hline 112 & 필리핀(ODA) & $\begin{array}{l}\text { 필리핀 WHO 다바오 } \\
\text { 지역보건체계 강화 모 } \\
\text { 자보건 사업 }\end{array}$ & 프로젝트 & 30.90 & 2.05 & 계속 & $2015-2018$ & 양자무상 & 1 \\
\hline 113 & 필리핀(ODA) & $\begin{array}{l}\text { 필리핀 경찰 수사역량 } \\
\text { 강화사업 }\end{array}$ & 프로젝트 & 75.24 & 32.10 & 계속 & $2016-2018$ & 양자무상 & 16 \\
\hline 114 & 필리핀(ODA) & $\begin{array}{l}\text { 필리핀 비사야스 주립 } \\
\text { 대 톨로사 캠퍼스 재 } \\
\text { 건사업 }\end{array}$ & 프로젝트 & 44.80 & 6.09 & 계속 & $2014-2018$ & 양자무상 & 4 \\
\hline 115 & 필리핀(ODA) & $\begin{array}{l}\text { 필리핀 북부 일로일로 } \\
\text { 태풍피해 어항복구사 } \\
\text { 업 }\end{array}$ & 프로젝트 & 82.40 & 25.00 & 계속 & $2015-2018$ & 양자무상 & 13 \\
\hline 116 & 필리핀(ODA) & \begin{tabular}{|l|} 
필리핀 동부사말 기안 \\
펠리페 아브리고 지역 \\
거점 공공병원 재건사 \\
업
\end{tabular} & 프로젝트 & 49.44 & 15.93 & 계속 & $2015-2018$ & 양자무상 & 3 \\
\hline 117 & 필리핀(ODA) & $\begin{array}{l}\text { 필리핀 UNESCO 타클 } \\
\text { 로반 지역 학교밖 소 } \\
\text { 녀를 위한 교육사업 }\end{array}$ & 프로젝트 & 69.00 & 34.50 & 계속 & $2017-2020$ & 양자무상 & 4 \\
\hline 118 & 필리핀(ODA) & $\begin{array}{l}\text { 필리핀 UNICEF 민다 } \\
\text { 나오지역 생애초기 } \\
1000 \text { 일간 영양개선사 } \\
\text { 업 }\end{array}$ & 프로젝트 & 69.00 & 1.00 & 신규 & $2018-2020$ & 양자무상 & 2 \\
\hline 119 & 필리핀(ODA) & \begin{tabular}{|l|} 
필리핀 퀴리노주 농업 \\
종합개발사업
\end{tabular} & 프로젝트 & 109.25 & 1.00 & 신규 & $2018-2022$ & 양자무상 & 1 \\
\hline 120 & 방글라데시(ODA) & $\begin{array}{l}\text { 방글라데시 간호전문 } \\
\text { 대학원 설립사업 }\end{array}$ & 프로젝트 & 147.70 & 7.00 & 계속 & $2012-2018$ & 양자무상 & 3 \\
\hline 121 & 방글라데시(ODA) & $\begin{array}{l}\text { 방글라데시 화학산업 } \\
\text { 기술훈련원 역량강화 } \\
\text { 사업 }\end{array}$ & 프로젝트 & 56.50 & - & 계속 & $2013-2018$ & 양자무상 & 4 \\
\hline 122 & 방글라데시(ODA) & $\begin{array}{l}\text { 방글라데시 안질환 예 } \\
\text { 방 및 치료역량강화사 } \\
\text { 업 } \\
\end{array}$ & 프로젝트 & 94.64 & 21.00 & 계속 & $2014-2020$ & 양자무상 & 3 \\
\hline 123 & 방글라데시(ODA) & $\begin{array}{l}\text { 방글라데시 } \\
\mathrm{KOICA}-\mathrm{UNICEF} \text { 예방 } \\
\text { 가능한 아동사망 감소 } \\
\text { 를 위한 모자보건증진 } \\
\text { 사업 }\end{array}$ & 프로젝트 & 82.40 & 3.30 & 계속 & $2015-2018$ & 양자무상 & 3 \\
\hline 124 & 방글라데시(ODA) & $\begin{array}{l}\text { 방글라데시 라즈샤히 } \\
\text { 직업훈련원 역량강화 } \\
\text { 사업 }\end{array}$ & 프로젝트 & 87.55 & 14.00 & 계속 & $2015-2019$ & 양자무상 & 4 \\
\hline 125 & 방글라데시(ODA) & $\begin{array}{l}\text { 방글라데시 소방방재 } \\
\text { 역량강화사업 }\end{array}$ & 프로젝트 & 86.53 & 20.00 & 계속 & $2016-2019$ & 양자무상 & 11 \\
\hline 126 & 방글라데시(ODA) & $\begin{array}{l}\text { 방글라데시 마약통제 } \\
\text { 행정역량강화사업 }\end{array}$ & 프로젝트 & 45.60 & 10.00 & 계속 & $2016-2019$ & 양자무상 & 16 \\
\hline
\end{tabular}




\begin{tabular}{|c|c|c|c|c|c|c|c|c|c|}
\hline & 세부사업명 & 내역사업명 & 사업 유형 & $\begin{array}{c}\text { 총사업예산 } \\
\text { (억원) }\end{array}$ & $\begin{array}{l}\text { ‘18년예 } \\
\text { 산 (억원) }\end{array}$ & $\begin{array}{l}\text { 신규/ } \\
\text { 계속 }\end{array}$ & $\begin{array}{l}\text { 총사업 } \\
\text { 기간 }\end{array}$ & $\begin{array}{c}\text { 구분 } \\
\text { (양-다자 } \\
\text { ) }\end{array}$ & $\begin{array}{l}\mathrm{SDGS} \\
\text { 목표 }\end{array}$ \\
\hline 127 & 방글라데시(ODA) & \begin{tabular}{|l} 
방글라데시 전자정부 \\
발전을 위한 마스터플 \\
랜 수립 및 역량강화 \\
사업
\end{tabular} & 프로젝트 & 35.84 & 10.00 & 계속 & $2014-2018$ & 양자무상 & 16 \\
\hline 128 & 방글라데시(ODA) & $\begin{array}{l}\text { 방글라데시 기술교육 } \\
\text { 및 청년취업 강화사업 }\end{array}$ & 프로젝트 & 97.75 & 1.00 & 신규 & $2018-2022$ & 양자무상 & 4 \\
\hline 129 & 방글라데시(ODA) & $\begin{array}{l}\text { 방글라데시 혁신 기업 } \\
\text { 가정신을 통한 청년창 } \\
\text { 업 지원사업 }\end{array}$ & 프로젝트 & 86.25 & 1.00 & 신규 & $2018-2021$ & 양자무상 & 9 \\
\hline 130 & 몽골(ODA) & $\begin{array}{l}\text { 몽골 광해관리 마스터 } \\
\text { 플랜 수립 및 역량강 } \\
\text { 화사업 }\end{array}$ & 프로젝트 & 64.96 & 24.13 & 계속 & $2014-2018$ & 양자무상 & 14 \\
\hline 131 & 몽골(ODA) & $\begin{array}{l}\text { 몽골 중기 재정계획 } \\
\text { 수립 역량강화 및 지 } \\
\text { 원시스템 구축사업 }\end{array}$ & 개발컨설팅 & 44.80 & 12.76 & 계속 & $2014-2018$ & 양자무상 & 16 \\
\hline 132 & 몽골(ODA) & $\begin{array}{l}\text { 몽골 헌법재판소 전자 } \\
\text { 소송시스템 구축사업 }\end{array}$ & 프로젝트 & 46.00 & 28.17 & 계속 & $2017-2018$ & 양자무상 & 16 \\
\hline 133 & 라오스(ODA) & $\begin{array}{l}\text { 라오스 통합모자보건 } \\
\text { 및 소아과 의료인력 } \\
\text { 교육사업 }\end{array}$ & 프로젝트 & 107.35 & 20.00 & 계속 & $2013-2018$ & 양자무상 & 3 \\
\hline 134 & 라오스(ODA) & $\begin{array}{l}\text { 라오스 수파누봉대학 } \\
\text { 교 교육역량강화사업 }\end{array}$ & 프로젝트 & 33.60 & - & 계속 & $2014-2018$ & 양자무상 & 4 \\
\hline 135 & 라오스(ODA) & $\begin{array}{l}\text { 라오스 경찰병원 역량 } \\
\text { 강화사업 }\end{array}$ & 프로젝트 & 56.00 & 10.00 & 계속 & $2014-2018$ & 양자무상 & 3 \\
\hline 136 & 라오스(ODA) & $\begin{array}{l}\text { 라오스 불발탄 제거 } \\
\text { 지원사업 }\end{array}$ & 프로젝트 & 33.60 & - & 계속 & $2014-2018$ & 양자무상 & 1 \\
\hline 137 & 라오스(ODA) & $\begin{array}{l}\text { 라오스 농촌공동체 개 } \\
\text { 발사업 }\end{array}$ & 프로젝트 & 162.96 & 30.00 & 계속 & $2014-2020$ & 양자무상 & 1 \\
\hline 138 & 라오스(ODA) & $\begin{array}{l}\text { 라오스 청년동맹 IT센 } \\
\text { 터 역량강화사업 }\end{array}$ & 프로젝트 & 34.20 & 18.00 & 계속 & $2016-2018$ & 양자무상 & 8 \\
\hline 139 & 라오스(ODA) & $\begin{array}{l}\text { 라오스-베트남 연결철 } \\
\text { 도(라오스 비엔티엔- } \\
\text { 타켓-무디아-베트남 } \\
\text { 붕앙) 타당성조사 사 } \\
\text { 업 }\end{array}$ & 개발컨설팅 & 30.90 & - & 계속 & $2015-2018$ & 양자무상 & 9 \\
\hline 140 & 라오스(ODA) & $\begin{array}{l}\text { 라오스 남능강 유역 } \\
\text { 통합수자원관리 마스 } \\
\text { 터플랜 수립사업 }\end{array}$ & 개발컨설팅 & 30.55 & 14.98 & 계속 & $2016-2018$ & 양자무상 & 11 \\
\hline 141 & 라오스(ODA) & \begin{tabular}{|l} 
라오스 아시안하이웨 \\
이 라오스 구간( 8 번 \\
국도) 개량 타당성조 \\
사 및 기본설계사업 \\
\end{tabular} & 개발컨설팅 & 39.90 & 19.00 & 계속 & $2016-2018$ & 양자무상 & 8 \\
\hline 142 & 라오스(ODA) & $\begin{array}{l}\text { 라오스 출입국 관리시 } \\
\text { 스템 개선 및 역량강 } \\
\text { 화사업 }\end{array}$ & 프로젝트 & 92.00 & 23.00 & 계속 & $2017-2019$ & 양자무상 & 8 \\
\hline 143 & 라오스(ODA) & \begin{tabular}{|l|} 
라오스 한-라 직업기 \\
술개발원 역량강화사 \\
업
\end{tabular} & 프로젝트 & 57.50 & 23.10 & 계속 & $2017-2020$ & 양자무상 & 4 \\
\hline 144 & 라오스(ODA) & \begin{tabular}{|l} 
라오스 사바나켓주 경 \\
제특구 개발을 위한 \\
지리공간정보 기반 구 \\
축 및 역량강화사업 \\
\end{tabular} & 개발컨설팅 & 69.00 & 1.00 & 신규 & $2018-2021$ & 양자무상 & 11 \\
\hline 145 & 스리랑카(ODA) & $\begin{array}{l}\text { 스리랑카 기술계 교사 } \\
\text { 양성 및 재교육 사업 } \\
\end{array}$ & 프로젝트 & 133.90 & 15.00 & 계속 & $2015-2019$ & 양자무상 & 4 \\
\hline 146 & 스리랑카(ODA) & $\begin{array}{l}\text { 스리랑카 마타라지역 } \\
\text { 모자보건의료역량강화 } \\
\text { 사업 }\end{array}$ & 프로젝트 & 96.90 & 15.00 & 계속 & $2016-2020$ & 양자무상 & 3 \\
\hline 147 & 스리랑카(ODA) & \begin{tabular}{|l|} 
스리랑카 해양 수산 \\
인력양성 중장기 마스 \\
터플랜 수립 사업
\end{tabular} & 개발컨설팅 & 28.75 & 5.00 & 계속 & $2017-2019$ & 양자무상 & 4 \\
\hline
\end{tabular}




\begin{tabular}{|c|c|c|c|c|c|c|c|c|c|}
\hline & 세부사업명 & 내역사업명 & 사업 유형 & $\begin{array}{c}\text { 총사업예산 } \\
\text { (억원) }\end{array}$ & $\begin{array}{l}\text { ‘18년예 } \\
\text { 산 (억원) }\end{array}$ & $\begin{array}{l}\text { 신규/ } \\
\text { 계속 }\end{array}$ & $\begin{array}{l}\text { 총사업 } \\
\text { 기간 }\end{array}$ & $\begin{array}{c}\text { 구분 } \\
\text { (양-다자 } \\
\text { ) }\end{array}$ & $\begin{array}{l}\mathrm{SDGS} \\
\text { 목표 }\end{array}$ \\
\hline 148 & 스리랑카(ODA) & $\begin{array}{l}\text { 스리랑카 킬리노치 교 } \\
\text { 사, 지역공동체 역량 } \\
\text { 강화 및 교육환경 개 } \\
\text { 선사업 }\end{array}$ & 프로젝트 & 86.25 & 1.00 & 신규 & $2018-2022$ & 양자무상 & 4 \\
\hline 149 & 네팔(ODA) & $\begin{array}{l}\text { 네팔 무구지역 모자보 } \\
\text { 건환경 개선사업 }\end{array}$ & 프로젝트 & 56.50 & 14.00 & 계속 & $2013-2018$ & 양자무상 & 3 \\
\hline 150 & 네팔(ODA) & $\begin{array}{l}\text { 네팔 농촌공동체 개발 } \\
\text { 사업 }\end{array}$ & 프로젝트 & 89.60 & 5.00 & 계속 & $2014-2019$ & 양자무상 & 6 \\
\hline 151 & 네팔(ODA) & $\begin{array}{l}\text { 네팔 직업교육(TVET) } \\
\text { 훈련교사 역량강화 사 } \\
\text { 업 }\end{array}$ & 프로젝트 & 51.50 & 1.60 & 계속 & $2015-2018$ & 양자무상 & 4 \\
\hline 152 & 네팔(ODA) & $\begin{array}{l}\text { 네팔 통합적 지역개발 } \\
\text { 을 위한 연구개발 인 } \\
\text { 프라 구축사업 }\end{array}$ & 프로젝트 & 114.00 & 3.00 & 계속 & $2016-2023$ & 양자무상 & 9 \\
\hline 153 & 네팔(ODA) & $\begin{array}{l}\text { 네팔 의료보험 제도구 } \\
\text { 축 지원사업 }\end{array}$ & 프로젝트 & 50.85 & 5.00 & 계속 & $2013-2018$ & 양자무상 & 3 \\
\hline 154 & 네팔(ODA) & $\begin{array}{l}\text { 네팔 누와꼿군 지진피 } \\
\text { 해보건분야 재건복구 } \\
\text { 지원사업 }\end{array}$ & 프로젝트 & 86.52 & 22.00 & 계속 & $2015-2018$ & 양자무상 & 3 \\
\hline 155 & 네팔(ODA) & $\begin{array}{l}\text { 네팔 UNESCO 포괄적 } \\
\text { 인 성교육 및 안전한 } \\
\text { 학습환경 조성을 통한 } \\
\text { 여성청소년 역량강화 } \\
\text { 사업 }\end{array}$ & 프로젝트 & 58.71 & 10.00 & 계속 & $2016-2020$ & 양자무상 & 4 \\
\hline 156 & 네팔(ODA) & $\begin{array}{l}\text { 네팔 UNDP 과일 및 } \\
\text { 채소 가치 사슬 개발 } \\
\text { 사업 }\end{array}$ & 프로젝트 & 57.50 & 1.00 & 신규 & $2018-2022$ & 양자무상 & 1 \\
\hline 157 & 파키스탄(ODA) & $\begin{array}{l}\text { 파키스탄 UNESCO 소 } \\
\text { 녀들의 교육권 현실화 } \\
\text { 를 위한 교육역량 강 } \\
\text { 화 지원사업 }\end{array}$ & 프로젝트 & 40.25 & 1.00 & 신규 & $2018-2021$ & 양자무상 & 4 \\
\hline 158 & 아프가니스탄(ODA) & $\begin{array}{l}\text { 아프가니스탄 카불시 } \\
\text { 바르치 지역 식수개발 } \\
\text { 사업 }\end{array}$ & 프로젝트 & 72.80 & 30.00 & 계속 & $2014-2019$ & 양자무상 & 6 \\
\hline 159 & $\begin{array}{l}\text { 아시아 비중점 국가그 } \\
\text { 룹(ODA) }\end{array}$ & $\begin{array}{l}\text { 동티모르 수산업 교육 } \\
\text { 훈련센터 지원사업 }\end{array}$ & 프로젝트 & 67.20 & 12.00 & 계속 & $2014-2018$ & 양자무상 & 14 \\
\hline 160 & $\begin{array}{l}\text { 아시아 비중점 국가그 } \\
\text { 룹(ODA) }\end{array}$ & $\begin{array}{l}\text { 동티모르 아이나로주 } \\
\text { 모성보건서비스 개선 } \\
\text { 사업 }\end{array}$ & 프로젝트 & 43.26 & 17.00 & 계속 & $2015-2018$ & 양자무상 & 3 \\
\hline 161 & $\begin{array}{l}\text { 아시아 비중점 국가그 } \\
\text { 룹(ODA) }\end{array}$ & $\begin{array}{l}\text { 동티모르 } \mathrm{WHO} \text { 소외 } \\
\text { 열대질환 통합관리 프 } \\
\text { 로그램 }\end{array}$ & 프로젝트 & 74.10 & 14.95 & 계속 & $2016-2020$ & 양자무상 & 3 \\
\hline 162 & $\begin{array}{l}\text { 아시아 비중점 국가그 } \\
\text { 룹(ODA) }\end{array}$ & $\begin{array}{l}\text { 솔로몬군도 국립대학 } \\
\text { 교 수산인력양성 지원 } \\
\text { 사업 }\end{array}$ & 프로젝트 & 56.00 & 2.00 & 계속 & $2014-2018$ & 양자무상 & 4 \\
\hline 163 & $\begin{array}{l}\text { 아시아 비중점 국가그 } \\
\text { 룹(ODA) }\end{array}$ & $\begin{array}{l}\text { 솔로몬군도 과달카날 } \\
\text { 주 모자보건체계 역량 } \\
\text { 강화사업 }\end{array}$ & 프로젝트 & 61.80 & 23.00 & 계속 & $2015-2019$ & 양자무상 & 3 \\
\hline 164 & $\begin{array}{l}\text { 아시아 비중점 국가그 } \\
\text { 룹(ODA) }\end{array}$ & $\begin{array}{l}\text { 중국 황사/미세먼지 } \\
\text { 관측망 운영 및 대처 } \\
\text { 기술 역량강화사업 }\end{array}$ & 프로젝트 & 22.40 & 1.27 & 계속 & $2014-2018$ & 양자무상 & 13 \\
\hline 165 & $\begin{array}{l}\text { 아시아 비중점 국가그 } \\
\text { 룹(ODA) }\end{array}$ & $\begin{array}{l}\text { 피지 타베우니섬 에너 } \\
\text { 지자립섬 시범사업을 } \\
\text { 통한 멜라네시아 4개 } \\
\text { 국 신재생에너지 역량 } \\
\text { 강화 사업 }\end{array}$ & 프로젝트 & 69.00 & 1.00 & 신규 & $2018-2020$ & 양자무상 & 7 \\
\hline 166 & $\begin{array}{l}\text { 아시아 비중점 국가그 } \\
\text { 룹(ODA) }\end{array}$ & 사업효과성제고비 & 기타 & & 240.67 & 계속 & 2018 & 양자무상 & \\
\hline 167 & $\begin{array}{l}\text { 아시아 비중점 국가그 } \\
\text { 룹(ODA) }\end{array}$ & 소규모무상원조 & 프로젝트 & & 18.00 & 계속 & 2018 & 양자무상 & \\
\hline 168 & $\begin{array}{l}\text { 아시아 비중점 국가그 } \\
\text { 룹(ODA) }\end{array}$ & 사업행정비 & 행정비용 & & 5.50 & 계속 & 2018 & 양자무상 & \\
\hline
\end{tabular}




\begin{tabular}{|c|c|c|c|c|c|c|c|c|c|}
\hline & 세부사업명 & 내역사업명 & 사업 유형 & $\begin{array}{c}\text { 총사업예산 } \\
\text { (억원) }\end{array}$ & $\begin{array}{l}\text { '18년 예 } \\
\text { 산 (억원) }\end{array}$ & $\begin{array}{l}\text { 신규/ } \\
\text { 계속 }\end{array}$ & $\begin{array}{l}\text { 총사업 } \\
\text { 기간 }\end{array}$ & $\begin{array}{c}\text { 구분 } \\
\text { (양-다자 } \\
\text { ) }\end{array}$ & $\begin{array}{l}\mathrm{SDGS} \\
\text { 목표 }\end{array}$ \\
\hline 169 & 미얀마(ODA) & $\begin{array}{l}\text { 미얀마 법령정보시스 } \\
\text { 템 구축사업 }\end{array}$ & 프로젝트 & 37.60 & 10.00 & 계속 & $2015-2018$ & 양자무상 & 16 \\
\hline 170 & 미얀마(ODA) & $\begin{array}{l}\text { 미얀마 내수면 수산양 } \\
\text { 식산업 기반조성 사업 }\end{array}$ & 프로젝트 & 49.39 & - & 계속 & $2014-2018$ & 양자무상 & 2 \\
\hline 171 & 미얀마(ODA) & $\begin{array}{l}\text { 미얀마 농촌공동체 개 } \\
\text { 발사업 }\end{array}$ & 프로젝트 & 246.40 & 55.87 & 계속 & $2014-2019$ & 양자무상 & 2 \\
\hline 172 & 미얀마(ODA) & $\begin{array}{l}\text { 미얀마 태양광발전을 } \\
\text { 통한 전력소외지역 생 } \\
\text { 활여건 개선사업 }\end{array}$ & 프로젝트 & 37.52 & - & 계속 & $2014-2018$ & 양자무상 & 7 \\
\hline 173 & 미얀마(ODA) & $\begin{array}{l}\text { 미얀마 수확후 기술관 } \\
\text { 리연구소 설립사업 }\end{array}$ & 프로젝트 & 50.40 & - & 계속 & $2014-2018$ & 양자무상 & 2 \\
\hline 174 & 미얀마(ODA) & $\begin{array}{l}\text { 미얀마 직업기술교사 } \\
\text { 교육원 설립사업 }\end{array}$ & 프로젝트 & 118.45 & 30.00 & 계속 & $2015-2019$ & 양자무상 & 4 \\
\hline 175 & 미얀마(ODA) & $\begin{array}{l}\text { 미얀마 농산물 유통 } \\
\text { 및 도매시장 설립 역 } \\
\text { 량강화 사업 }\end{array}$ & 프로젝트 & 85.84 & 30.00 & 계속 & $2016-2020$ & 양자무상 & 2 \\
\hline 176 & 미얀마(ODA) & $\begin{array}{l}\text { 미얀마 한따와디 신공 } \\
\text { 항인근 및 양곤 남서 } \\
\text { 부 지역개발 마스터플 } \\
\text { 랜 수립사업 }\end{array}$ & 개발컨설팅 & 51.50 & - & 계속 & $2015-2018$ & 양자무상 & 11 \\
\hline 177 & 미얀마(ODA) & $\begin{array}{l}\text { 미얀마 개발연구원 설 } \\
\text { 립사업 }\end{array}$ & 프로젝트 & 224.00 & 30.00 & 계속 & $2014-2019$ & 양자무상 & 16 \\
\hline 178 & 미얀마(ODA) & $\begin{array}{l}\text { 미얀마 에와야디 델타 } \\
\text { 지역 농업개발 마스터 } \\
\text { 플랜 지원사업 }\end{array}$ & 개발컨설팅 & 34.50 & 15.00 & 계속 & $2017-2019$ & 양자무상 & 2 \\
\hline 179 & 미얀마(ODA) & $\begin{array}{l}\text { 미얀마 중앙 중추고속 } \\
\text { 도로 타당성조사사업 }\end{array}$ & 개발컨설팅 & 86.25 & 1.00 & 신규 & $2018-2019$ & 양자무상 & 9 \\
\hline 180 & 가나(ODA) & \begin{tabular}{|l|} 
가나 CHPS 기반의 지 \\
역보건체계 강화사업
\end{tabular} & 프로젝트 & 102.60 & 16.00 & 계속 & $2016-2020$ & 양자무상 & 3 \\
\hline 181 & 가나(ODA) & $\begin{array}{l}\text { 가나 농민협동조합 역 } \\
\text { 량강화사업 } \\
\end{array}$ & 프로젝트 & 70.45 & 19.00 & 계속 & $2016-2019$ & 양자무상 & 1 \\
\hline 182 & 가나(ODA) & \begin{tabular}{|l} 
가나 UNICEF 여성청 \\
소년 권익과 교육 및 \\
보건 증진 사업
\end{tabular} & 프로젝트 & 63.25 & 18.90 & 계속 & $2017-2019$ & 양자무상 & 5 \\
\hline 183 & 가나(ODA) & \begin{tabular}{|l|} 
가나 글로벌보건안보 \\
구상 $(\mathrm{GHSA})$ 강화사업
\end{tabular} & 프로젝트 & 86.25 & 1.00 & 신규 & $2018-2020$ & 양자무상 & 3 \\
\hline 184 & 에티오피아(ODA) & $\begin{array}{l}\text { 에티오피아 참전용사 } \\
\text { 후손 직업역량배양사 } \\
\text { 업 }\end{array}$ & 프로젝트 & 96.30 & 1.20 & 계속 & $2012-2018$ & 양자무상 & 8 \\
\hline 185 & 에티오피아(ODA) & $\begin{array}{l}\text { 에티오피아 인구 및 } \\
\text { 생식보건 인식개선 캠 } \\
\text { 페인 지원사업 }\end{array}$ & 프로젝트 & 73.45 & 1.50 & 계속 & $2013-2018$ & 양자무상 & 5 \\
\hline 186 & 에티오피아(ODA) & \begin{tabular}{|l|} 
에티오피아 오로미아 \\
주 라디오방송을 통한 \\
초등교육역량강화사업 \\
\end{tabular} & 프로젝트 & 75.71 & 15.00 & 계속 & $2013-2018$ & 양자무상 & 4 \\
\hline 187 & 에티오피아(ODA) & $\begin{array}{l}\text { 에티오피아 티그라이 } \\
\text { 주 직업훈련학교 건립 } \\
\text { 사업 }\end{array}$ & 프로젝트 & 71.94 & 43.99 & 계속 & $2013-2018$ & 양자무상 & 4 \\
\hline 188 & 에티오피아(ODA) & $\begin{array}{l}\text { 에티오피아 재해경감 } \\
\text { 을 위한 기상관측 및 } \\
\text { 조기경보시스템 구축 } \\
\text { 사업 }\end{array}$ & 프로젝트 & 44.80 & - & 계속 & $2014-2018$ & 양자무상 & 13 \\
\hline 189 & 에티오피아(ODA) & $\begin{array}{l}\text { 에티오피아 오로미아 } \\
\text { 주 모자보건 및 가족 } \\
\text { 계획 역량강화사업 }\end{array}$ & 프로젝트 & 77.25 & 18.00 & 계속 & $2015-2019$ & 양자무상 & 3 \\
\hline 190 & 에티오피아(ODA) & $\begin{array}{l}\text { 에티오피아 통합보건 } \\
\text { 역량강화사업 }\end{array}$ & 프로젝트 & 61.80 & 12.00 & 계속 & $2015-2019$ & 양자무상 & 3 \\
\hline 191 & 에티오피아(ODA) & $\begin{array}{l}\text { 에티오피아 오로미아 } \\
\text { 주 도도타군 관개 및 } \\
\text { 농촌개발 역량강화사 } \\
\text { 업 }\end{array}$ & 프로젝트 & 179.67 & 30.00 & 계속 & $2013-2018$ & 양자무상 & 2 \\
\hline
\end{tabular}




\begin{tabular}{|c|c|c|c|c|c|c|c|c|c|}
\hline & 세부사업명 & 내역사업명 & 사업 유형 & $\begin{array}{c}\text { 총사업예산 } \\
\text { (억원) }\end{array}$ & $\begin{array}{l}\text { '18년 예 } \\
\text { 산 (억원) }\end{array}$ & $\begin{array}{l}\text { 신규/ } \\
\text { 계속 }\end{array}$ & $\begin{array}{l}\text { 총사업 } \\
\text { 기간 }\end{array}$ & $\begin{array}{c}\text { 구분 } \\
\text { (양-다자 } \\
\text { ) }\end{array}$ & $\begin{array}{l}\text { SDGs } \\
\text { 목표 }\end{array}$ \\
\hline 192 & 에티오피아(ODA) & $\begin{array}{l}\text { 에티오피아 싱글윈도 } \\
\text { 우사업(2단계) }\end{array}$ & 프로젝트 & 86.14 & 0.20 & 계속 & $2017-2020$ & 양자무상 & 9 \\
\hline 193 & 에티오피아(ODA) & $\begin{array}{l}\text { 에티오피아 암하라주 } \\
\text { 농촌개발전략 컨설팅 } \\
\text { 및 시범마을 사업 }\end{array}$ & 개발컨설팅 & 46.00 & 14.00 & 계속 & $2017-2020$ & 양자무상 & 2 \\
\hline 194 & 에티오피아(ODA) & $\begin{array}{l}\text { 에티오피아 모자보건 } \\
\text { 아웃리치 사업 : 짐마 } \\
\text { 지역 지역사회기반 모 } \\
\text { 성 및 신생아 보건서 } \\
\text { 비스체계 강화 }\end{array}$ & 프로젝트 & 41.84 & 10.20 & 계속 & $2016-2018$ & 양자무상 & 3 \\
\hline 195 & 모잠비크(ODA) & $\begin{array}{l}\text { 모잠비크 마톨라 산업 } \\
\text { 학교 역량강화사업 }\end{array}$ & 프로젝트 & 83.54 & 1.00 & 계속 & $2013-2018$ & 양자무상 & 4 \\
\hline 196 & 모잠비크(ODA) & $\begin{array}{l}\text { 모잠비크 잠베지아주 } \\
\text { 초등학교 환경개선 및 } \\
\text { 교육역량 강화사업 }\end{array}$ & 프로젝트 & 79.80 & 28.50 & 계속 & $2016-2018$ & 양자무상 & 4 \\
\hline 197 & 모잠비크(ODA) & $\begin{array}{l}\text { 모잠비크 잠베지지역 } \\
\text { 지도제작사업 }\end{array}$ & 개발컨설팅 & 50.40 & - & 계속 & $2014-2018$ & 양자무상 & 8 \\
\hline 198 & 르완다(ODA) & $\begin{array}{l}\text { 르완다 ICT 혁신 역 } \\
\text { 량강화 사업 }\end{array}$ & 프로젝트 & 63.28 & 25.00 & 계속 & $2013-2018$ & 양자무상 & 9 \\
\hline 199 & 르완다(ODA) & $\begin{array}{l}\text { 르완다 야루구루 농촌 } \\
\text { 종합개발사업 }\end{array}$ & 프로젝트 & 56.50 & 1.00 & 계속 & $2013-2018$ & 양자무상 & 2 \\
\hline 200 & 르완다(ODA) & $\begin{array}{l}\text { 르완다 공무원 행정역 } \\
\text { 량 강화사업 }\end{array}$ & 프로젝트 & 44.80 & 10.00 & 계속 & $2014-2018$ & 양자무상 & 16 \\
\hline 201 & 르완다(ODA) & \begin{tabular}{|l|} 
르완다 농촌공동체 개 \\
발사업
\end{tabular} & 프로젝트 & 123.20 & 35.00 & 계속 & $2014-2018$ & 양자무상 & 2 \\
\hline 202 & 르완다(ODA) & $\begin{array}{l}\text { 르완다 직업교육훈련 } \\
\text { 역량강화사업 }\end{array}$ & 프로그램 & 56.00 & 30.00 & 계속 & $2014-2018$ & 양자무상 & 4 \\
\hline 203 & 르완다(ODA) & $\begin{array}{l}\text { 르완다 산업연구개발 } \\
\text { 역량강화사업 }\end{array}$ & 개발컨설팅 & 28.00 & 1.01 & 계속 & $2014-2018$ & 양자무상 & 9 \\
\hline 204 & 르완다(ODA) & $\begin{array}{l}\text { 르완다 교사 및 예비 } \\
\text { 교사 ICT 교육 역량 } \\
\text { 강화사업 }\end{array}$ & 프로젝트 & 80.50 & 30.00 & 계속 & $2017-2020$ & 양자무상 & 4 \\
\hline 205 & 르완다(ODA) & $\begin{array}{l}\text { 르완다 세정 투명성 } \\
\text { 강화를 위한 통합 } \\
\text { EBM(Electronic Billing } \\
\text { Machine) 시스템 고도 } \\
\text { 화 및 역량강화사업 } \\
\end{array}$ & 프로젝트 & 69.00 & 1.00 & 신규 & $2018-2020$ & 양자무상 & 16 \\
\hline 206 & 우간다(ODA) & $\begin{array}{l}\text { 우간다 직업훈련원 건 } \\
\text { 립사업 }\end{array}$ & 프로젝트 & 51.75 & - & 계속 & $2011-2018$ & 양자무상 & 4 \\
\hline 207 & 우간다(ODA) & $\begin{array}{l}\text { 우간다 과일가공공장 } \\
\text { 건립사업 }\end{array}$ & 프로젝트 & 84.38 & - & 계속 & $2011-2018$ & 양자무상 & 8 \\
\hline 208 & 우간다(ODA) & $\begin{array}{l}\text { 우간다 엔테베 국제공 } \\
\text { 항 시스템 개선사업 }\end{array}$ & 프로젝트 & 106.40 & 18.72 & 계속 & $2014-2018$ & 양자무상 & 9 \\
\hline 209 & 우간다(ODA) & $\begin{array}{l}\text { 우간다 농촌개발 시범 } \\
\text { 마을 건립사업 }\end{array}$ & 프로젝트 & 25.75 & 8.11 & 계속 & $2015-2018$ & 양자무상 & 2 \\
\hline 210 & 우간다(ODA) & $\begin{array}{l}\text { 우간다 모자보건 아웃 } \\
\text { 리치 사업 : 이강가, } \\
\text { 카물리 지역아웃리치 } \\
\text { 를 통한 모자보건 서 } \\
\text { 비스 전달체계 강화사 } \\
\text { 업 }\end{array}$ & 프로젝트 & 43.55 & 8.43 & 계속 & $2016-2018$ & 양자무상 & 3 \\
\hline 211 & 우간다(ODA) & \begin{tabular}{|l|} 
우간다 UNICEF 카라 \\
모자 지역 초중등학교 \\
식수시설 보급 및 위 \\
생교육 사업
\end{tabular} & 프로젝트 & 92.00 & 1.00 & 신규 & $2018-2022$ & 양자무상 & 6 \\
\hline 212 & $\begin{array}{l}\text { 아프리카지역 비중점 } \\
\text { 국가그룹(ODA) }\end{array}$ & $\begin{array}{l}\mathrm{DR} \text { 콩고 국립박물관 } \\
\text { 건립사업 }\end{array}$ & 프로젝트 & 219.00 & 90.00 & 계속 & $2012-2019$ & 양자무상 & 4 \\
\hline 213 & $\begin{array}{l}\text { 아프리카지역 비중점 } \\
\text { 국가그룹(ODA) }\end{array}$ & $\begin{array}{l}\mathrm{DR} \text { 콩고 농촌지도역량 } \\
\text { 강화사업 }\end{array}$ & 프로젝트 & 91.20 & 31.00 & 계속 & $2016-2020$ & 양자무상 & 1 \\
\hline
\end{tabular}




\begin{tabular}{|c|c|c|c|c|c|c|c|c|c|}
\hline & 세부사업명 & 내역사업명 & 사업 유형 & $\begin{array}{c}\text { 총사업예산 } \\
\text { (억원) }\end{array}$ & $\begin{array}{l}\text { ‘18년예 } \\
\text { 산 (억원) }\end{array}$ & $\begin{array}{l}\text { 신규/ } \\
\text { 계속 }\end{array}$ & $\begin{array}{l}\text { 총사업 } \\
\text { 기간 }\end{array}$ & $\begin{array}{c}\text { 구분 } \\
\text { (양-다자 } \\
\text { ) }\end{array}$ & $\begin{array}{l}\text { SDGs } \\
\text { 목표 }\end{array}$ \\
\hline 214 & $\begin{array}{l}\text { 아프리카지역 비중점 } \\
\text { 국가그룹(ODA) }\end{array}$ & $\begin{array}{l}\mathrm{DR} \text { 콩고 글로벌 보건 } \\
\text { 안보(GHSA) 행동역량 } \\
\text { 진단평가 및 개선계획 } \\
\text { 수립사업 }\end{array}$ & 프로젝트 & 23.00 & 19.80 & 계속 & $2017-2018$ & 양자무상 & 3 \\
\hline 215 & $\begin{array}{l}\text { 아프리카지역 비중점 } \\
\text { 국가그룹(ODA) }\end{array}$ & $\begin{array}{l}\text { 나이지리아 초중등시 } \\
\text { 범학교단지 건립사업 }\end{array}$ & 프로젝트 & 169.50 & 50.00 & 계속 & $2013-2018$ & 양자무상 & 4 \\
\hline 216 & $\begin{array}{l}\text { 아프리카지역 비중점 } \\
\text { 국가그릅(ODA) }\end{array}$ & $\begin{array}{l}\text { 나이지리아 전자정부 } \\
\text { 역량강화사업 }\end{array}$ & 프로젝트 & 96.73 & 35.00 & 계속 & $2013-2018$ & 양자무상 & 16 \\
\hline 217 & $\begin{array}{l}\text { 아프리카지역 비중점 } \\
\text { 국가그룹(ODA) }\end{array}$ & \begin{tabular}{|l|} 
나이지리아 UNFPA \\
보르노주 여성 및 소 \\
녀를 위한 성생식보건 \\
및 젠더 강화 사업
\end{tabular} & 프로젝트 & 57.50 & 1.00 & 신규 & $2018-2020$ & 양자무상 & 3 \\
\hline 218 & $\begin{array}{l}\text { 아프리카지역 비중점 } \\
\text { 국가그룹(ODA) }\end{array}$ & $\begin{array}{l}\text { 남아공 농촌지도 역량 } \\
\text { 강화 컨설팅사업 }\end{array}$ & 개발컨설팅 & 34.20 & 12.42 & 계속 & $2016-2018$ & 양자무상 & 1 \\
\hline 219 & $\begin{array}{l}\text { 아프리카지역 비중점 } \\
\text { 국가그룹(ODA) }\end{array}$ & $\begin{array}{l}\text { 말리 UNESCO 교육을 } \\
\text { 통한 여성청소년 역량 } \\
\text { 강화 }\end{array}$ & 프로젝트 & 58.71 & 13.00 & 계속 & $2016-2020$ & 양자무상 & 4 \\
\hline 220 & $\begin{array}{l}\text { 아프리카지역 비중점 } \\
\text { 국가그룹(ODA) }\end{array}$ & $\begin{array}{l}\text { 수단 주혈흡충 및 소 } \\
\text { 외열대질환 퇴치사업 }\end{array}$ & 프로젝트 & 61.80 & 39.52 & 계속 & $2015-2018$ & 양자무상 & 3 \\
\hline 221 & $\begin{array}{l}\text { 아프리카지역 비중점 } \\
\text { 국가그룹(ODA) }\end{array}$ & $\begin{array}{l}\text { 앙골라 수산자원 조성 } \\
\text { 기술 역량강화사업 }\end{array}$ & 프로젝트 & 69.00 & 6.94 & 계속 & $2011-2018$ & 양자무상 & 2 \\
\hline 222 & $\begin{array}{l}\text { 아프리카지역 비중점 } \\
\text { 국가그룹(ODA) }\end{array}$ & $\begin{array}{l}\text { 앙골라 교사역량강화 } \\
\text { 및 지역사회 문해교육 } \\
2 \text { 차사업 }\end{array}$ & 프로젝트 & 29.64 & 7.27 & 계속 & $2016-2018$ & 양자무상 & 4 \\
\hline 223 & $\begin{array}{l}\text { 아프리카지역 비중점 } \\
\text { 국가그릅(ODA) }\end{array}$ & $\begin{array}{l}\text { 카메룬 국립직업훈련 } \\
\text { 교육원 건립사업 }\end{array}$ & 프로젝트 & 76.88 & 37.70 & 계속 & $2013-2018$ & 양자무상 & 4 \\
\hline 224 & $\begin{array}{l}\text { 아프리카지역 비중점 } \\
\text { 국가그룹(ODA) }\end{array}$ & \begin{tabular}{|l|} 
카메룬 전자정부 마스 \\
터플랜수립사업
\end{tabular} & 개발컨설팅 & 20.60 & - & 계속 & $2015-2018$ & 양자무상 & 16 \\
\hline 225 & $\begin{array}{l}\text { 아프리카지역 비중점 } \\
\text { 국가그룹(ODA) }\end{array}$ & $\begin{array}{l}\text { 카메룬 전자조달시스 } \\
\text { 템 구축 } 2 \text { 차 사업 }\end{array}$ & 프로젝트 & 64.40 & 1.00 & 신규 & $2018-2020$ & 양자무상 & 16 \\
\hline 226 & $\begin{array}{l}\text { 아프리카지역 비중점 } \\
\text { 국가그룹(ODA) }\end{array}$ & $\begin{array}{l}\text { 케냐 초등학교 환경개 } \\
\text { 선 및 역량강화사업 }\end{array}$ & 프로젝트 & 47.65 & 4.53 & 계속 & $2014-2019$ & 양자무상 & 4 \\
\hline 227 & $\begin{array}{l}\text { 아프리카지역 비중점 } \\
\text { 국가그룹(ODA) }\end{array}$ & $\begin{array}{l}\text { 케냐 분고마 추웰레지 } \\
\text { 역 식수개발사업 }\end{array}$ & 프로젝트 & 56.00 & 30.02 & 계속 & $2014-2018$ & 양자무상 & 6 \\
\hline 228 & $\begin{array}{l}\text { 아프리카지역 비중점 } \\
\text { 국가그룹(ODA) }\end{array}$ & $\begin{array}{l}\text { 케냐 국가산업훈련청 } \\
\text { 역량강화사업 }\end{array}$ & 개발컨설팅 & 44.90 & 24.36 & 계속 & $2014-2018$ & 양자무상 & 8 \\
\hline 229 & $\begin{array}{l}\text { 아프리카지역 비중점 } \\
\text { 국가그룹(ODA) }\end{array}$ & \begin{tabular}{|l} 
케냐 모자보건 아웃리 \\
치 사업 : 카지아도주 \\
모자보건 증진 및 보 \\
건인식 개선 강화
\end{tabular} & 프로젝트 & 48.22 & 14.64 & 계속 & $2016-2018$ & 양자무상 & 3 \\
\hline 230 & $\begin{array}{l}\text { 아프리카지역 비중점 } \\
\text { 국가그룹(ODA) }\end{array}$ & \begin{tabular}{|l|} 
케냐 분고마주 체퓩 \\
(Chepyuk)-키바비 \\
(Kibabii) 식수개발사 \\
업
\end{tabular} & 프로젝트 & 69.00 & 1.00 & 신규 & $2018-2021$ & 양자무상 & 6 \\
\hline 231 & $\begin{array}{l}\text { 아프리카지역 비중점 } \\
\text { 국가그룹(ODA) }\end{array}$ & $\begin{array}{l}\text { 코트디부아르 한-코 } \\
\text { 협력센터 건립사업 }\end{array}$ & 프로젝트 & 97.85 & 46.00 & 계속 & $2015-2019$ & 양자무상 & 4 \\
\hline 232 & $\begin{array}{l}\text { 아프리카지역 비중점 } \\
\text { 국가그룹(ODA) }\end{array}$ & $\begin{array}{l}\text { 코트디부아르 UNFPA } \\
\text { 여성 누관치료 및 예 } \\
\text { 방 2차 사업 }\end{array}$ & 프로젝트 & 72.39 & 9.06 & 계속 & $2016-2018$ & 양자무상 & 3 \\
\hline 233 & $\begin{array}{l}\text { 아프리카지역 비중점 } \\
\text { 국가그룹(ODA) }\end{array}$ & \begin{tabular}{|l|} 
코트디부아르 아비장 \\
시 상수급수 연결 2차 \\
사업
\end{tabular} & 프로젝트 & 67.85 & 1.00 & 신규 & $2018-2020$ & 양자무상 & 6 \\
\hline 234 & $\begin{array}{l}\text { 아프리카지역 비중점 } \\
\text { 국가그릅(ODA) }\end{array}$ & 사업효과성제고비 & 기타 & & 154.22 & 계속 & 2018 & 양자무상 & \\
\hline 235 & $\begin{array}{l}\text { 아프리카지역 비중점 } \\
\text { 국가그룹(ODA) }\end{array}$ & 소규모무상원조 & 프로젝트 & & 40.00 & 계속 & 2018 & 양자무상 & \\
\hline 236 & $\begin{array}{l}\text { 아프리카지역 비중점 } \\
\text { 국가그룹(ODA) }\end{array}$ & 사업행정비 & 행정비용 & & 4.94 & 계속 & 2018 & 양자무상 & \\
\hline 237 & $\begin{array}{l}\text { 아프리카지역 비중점 } \\
\text { 국가그룹(ODA) }\end{array}$ & 전략사업비 & 프로젝트 & & 180.00 & 계속 & 2018 & 양자무상 & \\
\hline
\end{tabular}




\begin{tabular}{|c|c|c|c|c|c|c|c|c|c|}
\hline & 세부사업명 & 내역사업명 & 사업 유형 & $\begin{array}{c}\text { 총사업예산 } \\
\text { (억원) }\end{array}$ & $\begin{array}{l}\text { '18년 예 } \\
\text { 산 (억원) }\end{array}$ & $\begin{array}{l}\text { 신규/ } \\
\text { 계속 }\end{array}$ & $\begin{array}{l}\text { 총사업 } \\
\text { 기간 }\end{array}$ & $\begin{array}{c}\text { 구분 } \\
\text { (양-다자 } \\
\text { ) }\end{array}$ & $\begin{array}{l}\mathrm{SDGS} \\
\text { 목표 }\end{array}$ \\
\hline 238 & 탄자니아(ODA) & $\begin{array}{l}\text { 탄자니아 차니카 모자 } \\
\text { 보건 서비스 개선사업 }\end{array}$ & 프로젝트 & 47.65 & 12.31 & 계속 & $2014-2018$ & 양자무상 & 3 \\
\hline 239 & 탄자니아(ODA) & $\begin{array}{l}\text { 탄자니아 세렝게티 국 } \\
\text { 립공원 홍보관 개선사 } \\
\text { 업 }\end{array}$ & 프로젝트 & 15.45 & 0.17 & 계속 & $2015-2018$ & 양자무상 & 15 \\
\hline 240 & 탄자니아(ODA) & $\begin{array}{l}\text { 탄자니아 보건분야 공 } \\
\text { 동재정지원 }\end{array}$ & 프로그램 & 78.66 & 31.11 & 계속 & $2016-2018$ & 양자무상 & 3 \\
\hline 241 & 탄자니아(ODA) & $\begin{array}{l}\text { 탄자니아 잔지바 양식 } \\
\text { 개발 지원사업 }\end{array}$ & 프로젝트 & 40.32 & 7.75 & 계속 & $2014-2018$ & 양자무상 & 14 \\
\hline 242 & 탄자니아(ODA) & $\begin{array}{l}\text { 탄자니아 UNESCO 교 } \\
\text { 육을 통한 탄자니아 } \\
\text { 여성청소년 역량강화 }\end{array}$ & 프로젝트 & 58.71 & 15.77 & 계속 & $2016-2020$ & 양자무상 & 4 \\
\hline 243 & 탄자니아(ODA) & $\begin{array}{l}\text { 탄자니아 잔지바르 중 } \\
\text { 등교육 질 향상을 위 } \\
\text { 한 통합적 교육환경 } \\
\text { 개선사 }\end{array}$ & 프로젝트 & 115.00 & 1.00 & 신규 & $2018-2022$ & 양자무상 & 4 \\
\hline 244 & 탄자니아(ODA) & $\begin{array}{l}\text { 탄자니아 싱글윈도우 } \\
\text { 시스템 구축 지원 사 } \\
\text { 업 }\end{array}$ & 프로젝트 & 69.00 & 2.00 & 신규 & $2018-2020$ & 양자무상 & 8 \\
\hline 245 & 세네갈(ODA) & $\begin{array}{l}\text { 세네갈 농업생산성 증 } \\
\text { 대사업 }\end{array}$ & 프로젝트 & 33.60 & 2.00 & 계속 & $2014-2018$ & 양자무상 & 1 \\
\hline 246 & 세네갈(ODA) & $\begin{array}{l}\text { 세네갈 고등기술전문 } \\
\text { 전문대학(ISEP) 설립 } \\
\text { 사업 }\end{array}$ & 프로젝트 & 92.70 & 27.00 & 계속 & $2015-2019$ & 양자무상 & 4 \\
\hline 247 & 세네갈(ODA) & $\begin{array}{l}\text { 세네갈 중부지역 식수 } \\
\text { 위생개선사업 }\end{array}$ & 프로젝트 & 51.50 & 25.77 & 계속 & $2015-2018$ & 양자무상 & 6 \\
\hline 248 & 세네갈(ODA) & $\begin{array}{l}\text { 세네갈 지속가능한 미 } \\
\text { 곡 가치사슬 강화사업 }\end{array}$ & 프로젝트 & 96.90 & 40.00 & 계속 & $2016-2022$ & 양자무상 & 2 \\
\hline 249 & 세네갈(ODA) & $\begin{array}{l}\text { 세네갈 농업기술학교 } \\
\text { 역량강화사업 }\end{array}$ & 개발컨설팅 & 33.60 & 12.30 & 계속 & $2014-2018$ & 양자무상 & 1 \\
\hline 250 & 세네갈(ODA) & $\begin{array}{l}\text { 세네갈중부지역모자보 } \\
\text { 건체계강화사업 }\end{array}$ & 프로젝트 & 92.00 & 1.00 & 신규 & $2018-2022$ & 양자무상 & 3 \\
\hline 251 & 세네갈(ODA) & $\begin{array}{l}\text { 세네갈 영유아교육 강 } \\
\text { 화사업 }\end{array}$ & 프로젝트 & 49.45 & 1.00 & 신규 & $2018-2021$ & 양자무상 & 4 \\
\hline 252 & 콜롬비아(ODA) & $\begin{array}{l}\text { 콜롬비아 산업클러스 } \\
\text { 터 기반 중소기업 생 } \\
\text { 산경쟁력 강화사업 }\end{array}$ & 개발컨설팅 & 34.50 & 2.30 & 계속 & $2011-2018$ & 양자무상 & 9 \\
\hline 253 & 콜롬비아(ODA) & $\begin{array}{l}\text { 콜롬비아 과채류 시장 } \\
\text { 경쟁력 강화사업 }\end{array}$ & 개발컨설팅 & 45.60 & 12.43 & 계속 & $2016-2020$ & 양자무상 & 2 \\
\hline 254 & 콜롬비아(ODA) & $\begin{array}{l}\text { 콜롬비아 자동차부품 } \\
\text { 산업 경쟁력 강화사업 }\end{array}$ & 개발컨설팅 & 59.28 & 20.23 & 계속 & $2016-2020$ & 양자무상 & 9 \\
\hline 255 & 콜롬비아(ODA) & $\begin{array}{l}\text { 콜롬비아 UNHCR 내 } \\
\text { 전 피해 국내난민 정 } \\
\text { 착지원 및 지속 가능 } \\
\text { 해결 방안 제시를 통 } \\
\text { 한 평화 구축 사업 }\end{array}$ & 프로젝트 & 57.50 & 1.00 & 신규 & $2018-2020$ & 양자무상 & 16 \\
\hline 256 & 페루(ODA) & $\begin{array}{l}\text { 페루 파차쿠텍 보건의 } \\
\text { 료 역량강화사업 }\end{array}$ & 프로젝트 & 37.70 & 5.00 & 계속 & $2013-2018$ & 양자무상 & 3 \\
\hline 257 & 페루(ODA) & $\begin{array}{l}\text { 페루 중소 수출입기업 } \\
\text { 을 위한 전자무역업무 } \\
\text { 개선사업 }\end{array}$ & 프로젝트 & 56.00 & 28.75 & 계속 & $2014-2018$ & 양자무상 & 9 \\
\hline 258 & 페루(ODA) & $\begin{array}{l}\text { 페루 지속가능한 자원 } \\
\text { 개발을 위한 광해관리 } \\
\text { 업무 정보화 시스템 } \\
\text { 구축사업 }\end{array}$ & 개발컨설팅 & 26.78 & 1.66 & 계속 & $2015-2018$ & 양자무상 & 1 \\
\hline 259 & 페루(ODA) & $\begin{array}{l}\text { 페루 국가문화유산 통 } \\
\text { 합등록 및 관리시스템 } \\
\text { 구축 사업 }\end{array}$ & 개발컨설팅 & 82.40 & 45.00 & 계속 & $2015-2018$ & 양자무상 & 1 \\
\hline
\end{tabular}




\begin{tabular}{|c|c|c|c|c|c|c|c|c|c|}
\hline & 세부사업명 & 내역사업명 & 사업 유형 & $\begin{array}{c}\text { 총사업예산 } \\
\text { (억원) }\end{array}$ & $\begin{array}{l}\text { ‘18년예 } \\
\text { 산 (억원) }\end{array}$ & $\begin{array}{l}\text { 신규/ } \\
\text { 계속 }\end{array}$ & $\begin{array}{l}\text { 총사업 } \\
\text { 기간 }\end{array}$ & $\begin{array}{c}\text { 구분 } \\
\text { (양-다자 } \\
\text { ) }\end{array}$ & $\begin{array}{l}\mathrm{SDGS} \\
\text { 목표 }\end{array}$ \\
\hline 260 & 페루(ODA) & \begin{tabular}{|l|} 
페루 ICT기반 혁신단 \\
지 설립 사업(마스터 \\
플랜 및 R\&D 시범센 \\
터 구축)
\end{tabular} & 개발컨설팅 & 114.00 & 28.00 & 계속 & $2016-2020$ & 양자무상 & 1 \\
\hline 261 & 페루(ODA) & \begin{tabular}{|l|} 
페루아마존지역태양광 \\
에너지기반바이오비즈 \\
니스생산성제고모델수 \\
립사업
\end{tabular} & 프로젝트 & 20.70 & 10.35 & 계속 & $2017-2019$ & 양자무상 & 7 \\
\hline 262 & 볼리비아(ODA) & $\begin{array}{l}\text { 볼리비아 오루로 보건 } \\
\text { 의료시스템 향상 및 } \\
\text { 의료인력 역량강화사 } \\
\text { 업 }\end{array}$ & 프로젝트 & 140.65 & - & 계속 & $2011-2018$ & 양자무상 & 3 \\
\hline 263 & 볼리비아(ODA) & $\begin{array}{l}\text { 볼리비아 추키사카주 } \\
\text { 저수용댐 축조 및 관 } \\
\text { 개수로 건설사업 }\end{array}$ & 프로젝트 & 126.95 & 20.00 & 계속 & $2011-2018$ & 양자무상 & 6 \\
\hline 264 & 볼리비아(ODA) & $\begin{array}{l}\text { 볼리비아 엘알또 한국 } \\
\text { 병원 3차 지원사업 }\end{array}$ & 프로젝트 & 94.92 & 15.00 & 계속 & $2013-2018$ & 양자무상 & 3 \\
\hline 265 & 볼리비아(ODA) & $\begin{array}{l}\text { 볼리비아 고원지역 농 } \\
\text { 업기계화 및 농민 역 } \\
\text { 량강화를 통한 생산성 } \\
\text { 증대 지원사업 }\end{array}$ & 프로젝트 & 56.50 & 20.00 & 계속 & $2013-2018$ & 양자무상 & 8 \\
\hline 266 & 볼리비아(ODA) & $\begin{array}{l}\text { 볼리비아 고원지역 건 } \\
\text { 강증진 및 삶의 질 향 } \\
\text { 상 프로그램 }\end{array}$ & 프로젝트 & 103.50 & 23.00 & 계속 & $2017-2022$ & 양자무상 & 3 \\
\hline 267 & 볼리비아(ODA) & $\begin{array}{l}\text { 볼리비아 베니주 트리 } \\
\text { 니다드시 상수도시설 } \\
\text { 구축사업 }\end{array}$ & 프로젝트 & 80.50 & 1.00 & 신규 & $2018-2021$ & 양자무상 & 6 \\
\hline 268 & 볼리비아(ODA) & $\begin{array}{l}\text { 볼리비아 UNICEF 코 } \\
\text { 차밤바, 판도 주 원주 } \\
\text { 민 지역사회 내 보건 } \\
\text { 및 교육 서비스의 성 } \\
\text { 인지적 대응사업 }\end{array}$ & 프로젝트 & 23.00 & 1.00 & 신규 & $2018-2020$ & 양자무상 & 3 \\
\hline 269 & 파라과이(ODA) & $\begin{array}{l}\text { 파라과이 산빠블로 모 } \\
\text { 자병원 역량강화사업 }\end{array}$ & 프로젝트 & 77.74 & 39.17 & 계속 & $2013-2018$ & 양자무상 & 3 \\
\hline 270 & 파라과이(ODA) & $\begin{array}{l}\text { 파라과이 포용적이고 } \\
\text { 지속가능한 농촌공동 } \\
\text { 체 사업 }\end{array}$ & 프로젝트 & 72.10 & 24.00 & 계속 & $2015-2018$ & 양자무상 & 2 \\
\hline 271 & 파라과이(ODA) & $\begin{array}{l}\text { 파라과이 센트럴주 림 } \\
\text { 삐오시 보건의료체계 } \\
\text { 형성 및 일차의료 강 } \\
\text { 화사업 }\end{array}$ & 프로젝트 & 158.46 & 57.50 & 계속 & $2016-2022$ & 양자무상 & 3 \\
\hline 272 & 파라과이(ODA) & $\begin{array}{l}\text { 파라과이 취약계층 노 } \\
\text { 인 보건의료복지센터 } \\
\text { 정책수립 지원사업 } \\
\end{array}$ & 프로젝트 & 114.00 & 48.76 & 계속 & $2016-2020$ & 양자무상 & 10 \\
\hline 273 & 파라과이(ODA) & $\begin{array}{l}\text { 파라과이 아순시온시 } \\
\text { 바냐도수르 상습 수해 } \\
\text { 지역 개선 마스터플랜 } \\
\text { 수립사업 }\end{array}$ & 개발컨설팅 & 40.25 & 1.00 & 신규 & $2018-2019$ & 양자무상 & 11 \\
\hline 274 & $\begin{array}{l}\text { 중남미지역 비중점 국 } \\
\text { 가그룹(ODA) }\end{array}$ & $\begin{array}{l}\text { 과테말라 치안강화를 } \\
\text { 위한 경찰교육시스템 } \\
\text { 개선사업 }\end{array}$ & 프로젝트 & 44.41 & 8.00 & 계속 & $2014-2018$ & 양자무상 & 16 \\
\hline 275 & $\begin{array}{l}\text { 중남미지역 비중점 국 } \\
\text { 가그룹(ODA) }\end{array}$ & $\begin{array}{l}\text { 과테말라 } \mathrm{FAO} \text { 기후변 } \\
\text { 화대응 종합적 혼농임 } \\
\text { 업 역량강화사업 }\end{array}$ & 프로젝트 & 80.50 & 1.00 & 신규 & $2018-2021$ & 양자무상 & 2 \\
\hline 276 & $\begin{array}{l}\text { 중남미지역 비중점 국 } \\
\text { 가그룹(ODA) }\end{array}$ & $\begin{array}{l}\text { 니카라과 중등교사 } \\
\text { ICT교육 역량강화 사 } \\
\text { 업 }\end{array}$ & 프로젝트 & 34.50 & 4.55 & 계속 & $2017-2020$ & 양자무상 & 4 \\
\hline 277 & $\begin{array}{l}\text { 중남미지역 비중점 국 } \\
\text { 가그룹(ODA) }\end{array}$ & $\begin{array}{l}\text { 니카라과 공무원 정책 } \\
\text { 개발역량 강화 사업 }\end{array}$ & 개발컨설팅 & 20.70 & 17.70 & 계속 & $2017-2018$ & 양자무상 & 16 \\
\hline 278 & $\begin{array}{l}\text { 중남미지역 비중점 국 } \\
\text { 가그룹(ODA) } \\
\end{array}$ & $\begin{array}{l}\text { 도미니카공화국 과학 } \\
\text { 기술인력 양성사업 } \\
\end{array}$ & 프로젝트 & 41.20 & 10.00 & 계속 & $2015-2018$ & 양자무상 & 1 \\
\hline
\end{tabular}




\begin{tabular}{|c|c|c|c|c|c|c|c|c|c|}
\hline & 세부사업명 & 내역사업명 & 사업 유형 & $\begin{array}{c}\text { 총사업예산 } \\
\text { (억원) }\end{array}$ & $\begin{array}{l}\text { '18년예 } \\
\text { 산 (억원) }\end{array}$ & $\begin{array}{l}\text { 신규/ } \\
\text { 계속 }\end{array}$ & $\begin{array}{l}\text { 총사업 } \\
\text { 기간 }\end{array}$ & $\begin{array}{c}\text { 구분 } \\
\text { (양-다자 } \\
\text { ) }\end{array}$ & $\begin{array}{l}\mathrm{SDGS} \\
\text { 목표 }\end{array}$ \\
\hline 279 & $\begin{array}{l}\text { 중남미지역 비중점 국 } \\
\text { 가그룹(ODA) }\end{array}$ & $\begin{array}{l}\text { 도미니카공화국 미성 } \\
\text { 년자 임신방지 및 여 } \\
\text { 성보건환경개선 3차 } \\
\text { 사업 }\end{array}$ & 프로젝트 & 46.00 & 1.00 & 신규 & $2018-2022$ & 양자무상 & 3 \\
\hline 280 & $\begin{array}{l}\text { 중남미지역 비중점 국 } \\
\text { 가그륩(ODA) }\end{array}$ & $\begin{array}{l}\text { 아이티 UNDP 취약계 } \\
\text { 층 여성 역량강화 및 } \\
\text { 소득증진 사업 }\end{array}$ & 프로젝트 & 51.75 & 1.00 & 신규 & $2018-2020$ & 양자무상 & 4 \\
\hline 281 & $\begin{array}{l}\text { 중남미지역 비중점 국 } \\
\text { 가그룹(ODA) }\end{array}$ & $\begin{array}{l}\text { 에콰도르 과야스주 보 } \\
\text { 건의료센터 건립 및 } \\
\text { 의료인력 역량강화사 } \\
\text { 업 }\end{array}$ & 프로젝트 & 64.45 & 20.00 & 계속 & $2014-2019$ & 양자무상 & 3 \\
\hline 282 & $\begin{array}{l}\text { 중남미지역 비중점 국 } \\
\text { 가그룹(ODA) }\end{array}$ & $\begin{array}{l}\text { 에콰도르 침보라소주 } \\
\text { 관개수로건설 및 영농 } \\
\text { 기술지원 } 2 \text { 차 사업 }\end{array}$ & 프로젝트 & 22.40 & 7.73 & 계속 & $2014-2018$ & 양자무상 & 6 \\
\hline 283 & $\begin{array}{l}\text { 중남미지역 비중점 국 } \\
\text { 가그룹(ODA) }\end{array}$ & $\begin{array}{l}\text { 에콰도르 야차이 지식 } \\
\text { 기반도시 창업지원 및 } \\
\text { 기술이전센터 건립사 } \\
\text { 업 }\end{array}$ & 프로젝트 & 57.00 & 5.76 & 계속 & $2016-2019$ & 양자무상 & 9 \\
\hline 284 & $\begin{array}{l}\text { 중남미지역 비중점 국 } \\
\text { 가그룹(ODA) }\end{array}$ & $\begin{array}{l}\text { 엘살바도르 한-엘 의 } \\
\text { 료센터 건립사업 }\end{array}$ & 프로젝트 & 33.90 & 9.00 & 계속 & $2013-2018$ & 양자무상 & 3 \\
\hline 285 & $\begin{array}{l}\text { 중남미지역 비중점 국 } \\
\text { 가그룹(ODA) }\end{array}$ & $\begin{array}{l}\text { 엘살바도르 치안강화 } \\
\text { 를 위한 차량 자동인 } \\
\text { 식 시스템 구축사업 }\end{array}$ & 프로젝트 & 47.04 & 5.00 & 계속 & $2014-2018$ & 양자무상 & 16 \\
\hline 286 & $\begin{array}{l}\text { 중남미지역 비중점 국 } \\
\text { 가그룹(ODA) }\end{array}$ & $\begin{array}{l}\text { 엘살바도르 동부건조 } \\
\text { 지역 수계 복원력증대 } \\
\text { 를 통한 기후변화대응 } \\
\text { 사업 }\end{array}$ & 프로젝트 & 92.00 & 25.00 & 계속 & $2017-2020$ & 양자무상 & 6 \\
\hline 287 & $\begin{array}{l}\text { 중남미지역 비중점 국 } \\
\text { 가그룹(ODA) }\end{array}$ & $\begin{array}{l}\text { 온두라스 치안역량강 } \\
\text { 화사업 }\end{array}$ & 프로젝트 & 62.10 & 5.00 & 계속 & $2013-2018$ & 양자무상 & 16 \\
\hline 288 & $\begin{array}{l}\text { 중남미지역 비중점 국 } \\
\text { 가그룹(ODA) }\end{array}$ & $\begin{array}{l}\text { 온두라스 교원 ICT } \\
\text { 활용능력 강화사업 }\end{array}$ & 프로젝트 & 20.70 & 1.00 & 신규 & $2018-2021$ & 양자무상 & 4 \\
\hline 289 & $\begin{array}{l}\text { 중남미지역 비중점 국 } \\
\text { 가그룹(ODA) }\end{array}$ & $\begin{array}{l}\text { 카리브해 국가연합 기 } \\
\text { 후변화가 모래 해안선 } \\
\text { 에 미치는 영향 : 대 } \\
\text { 안적 관리방안 }\end{array}$ & 개발컨설팅 & 39.56 & 22.15 & 계속 & $2017-2018$ & 양자무상 & 14 \\
\hline 290 & $\begin{array}{l}\text { 중남미지역 비중점 국 } \\
\text { 가그룹(ODA) }\end{array}$ & 사업효과성제고비 & 기타 & & 60.13 & 계속 & 2018 & 양자무상 & \\
\hline 291 & $\begin{array}{l}\text { 중남미지역 비중점 국 } \\
\text { 가그룹(ODA) }\end{array}$ & 소규모무상원조 & 프로젝트 & & 20.00 & 계속 & 2018 & 양자무상 & \\
\hline 292 & $\begin{array}{l}\text { 중남미지역 비중점 국 } \\
\text { 가그룹(ODA) }\end{array}$ & 사업행정비 & 행정비용 & & 1.73 & 계속 & 2018 & 양자무상 & \\
\hline 293 & 우즈베키스탄(ODA) & $\begin{array}{l}\text { 우즈베키스탄전염성질 } \\
\text { 병관리역량강화사업 }\end{array}$ & 프로젝트 & 67.80 & 3.50 & 계속 & $2013-2018$ & 양자무상 & 3 \\
\hline 294 & 우즈베키스탄(ODA) & $\begin{array}{l}\text { 우즈베키스탄 사흐리 } \\
\text { 사브즈시 훈련센터 설 } \\
\text { 립 및 직업훈련 역량 } \\
\text { 강화 컨설팅사업 }\end{array}$ & 프로젝트 & 95.20 & 10.00 & 계속 & $2014-2018$ & 양자무상 & 1 \\
\hline 295 & 우즈베키스탄(ODA) & $\begin{array}{l}\text { 우즈베키스탄 표준청 } \\
\text { 국제동등성 확보 지원 } \\
\text { 및 통합시스템 구축사 } \\
\text { 업 }\end{array}$ & 프로젝트 & 78.40 & 25.00 & 계속 & $2014-2018$ & 양자무상 & 16 \\
\hline 296 & 우즈베키스탄(ODA) & $\begin{array}{l}\text { 우즈베키스탄 ICT 기 } \\
\text { 반의 통합물관리 마스 } \\
\text { 터플랜 수립 및 시설 } \\
\text { 기반강화 시범사업 }\end{array}$ & 프로젝트 & 79.80 & 13.00 & 계속 & $2016-2019$ & 양자무상 & 6 \\
\hline 297 & 우즈베키스탄(ODA) & $\begin{array}{l}\text { 우즈베키스탄 아동병 } \\
\text { 원 의료인력 역량강화 } \\
\text { 사업 }\end{array}$ & 개발컨설팅 & 72.10 & 15.00 & 계속 & $2015-2020$ & 양자무상 & 3 \\
\hline 298 & 우즈베키스탄(ODA) & $\begin{array}{l}\text { 우즈베키스탄 공공부 } \\
\text { 문 인적자원 역량개발 } \\
\text { 사업 }\end{array}$ & 개발컨설팅 & 34.50 & 14.00 & 계속 & $2017-2019$ & 양자무상 & 16 \\
\hline
\end{tabular}




\begin{tabular}{|c|c|c|c|c|c|c|c|c|c|}
\hline & 세부사업명 & 내역사업명 & 사업 유형 & $\begin{array}{c}\text { 총사업예산 } \\
\text { (억원) }\end{array}$ & $\begin{array}{l}\text { ‘18년예 } \\
\text { 산 (억원) }\end{array}$ & $\begin{array}{l}\text { 신규/ } \\
\text { 계속 }\end{array}$ & $\begin{array}{l}\text { 총사업 } \\
\text { 기간 }\end{array}$ & $\begin{array}{c}\text { 구분 } \\
\text { (양-다자 } \\
\text { ) }\end{array}$ & $\begin{array}{l}\mathrm{SDGS} \\
\text { 목표 }\end{array}$ \\
\hline 299 & 우즈베키스탄(ODA) & $\begin{array}{l}\text { 우즈베키스탄 코간드 } \\
\text { 직업훈련원 건립사업 }\end{array}$ & 프로젝트 & 102.35 & 1.00 & 신규 & $2018-2022$ & 양자무상 & 4 \\
\hline 300 & 우즈베키스탄(ODA) & 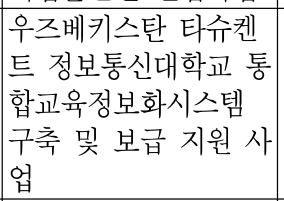 & 프로젝트 & 34.50 & 1.00 & 신규 & $2018-2021$ & 양자무상 & 4 \\
\hline 301 & 아제르바이잔(ODA) & $\begin{array}{l}\text { 아제르바이잔 교사역 } \\
\text { 량강화 및 교육정보화 } \\
\text { 지원사업 }\end{array}$ & 프로젝트 & 67.20 & 11.00 & 계속 & $2014-2018$ & 양자무상 & 4 \\
\hline 302 & 아제르바이잔(ODA) & $\begin{array}{l}\text { 아제르바이잔 코자밴 } \\
\text { 드지역 상하수도 시설 } \\
\text { 구축사업 }\end{array}$ & 프로젝트 & 121.98 & 1.00 & 계속 & $2016-2018$ & 양자무상 & 6 \\
\hline 303 & 아제르바이잔(ODA) & $\begin{array}{l}\text { 아제르바이잔 IOM 물 } \\
\text { 공급시스템(카흐리즈) } \\
\text { 구축 지원사업 }\end{array}$ & 프로젝트 & 51.75 & 1.00 & 신규 & $2018-2021$ & 양자무상 & 6 \\
\hline 304 & 이라크(ODA) & $\begin{array}{l}\text { 이라크 배전분야 에너 } \\
\text { 지 효율개선 및 자동 } \\
\text { 검침 시스템 구축사업 }\end{array}$ & 프로젝트 & 46.01 & 10.00 & 계속 & $2012-2018$ & 양자무상 & 7 \\
\hline 305 & 이라크(ODA) & $\begin{array}{l}\text { 이라크 KRG 아르빌, } \\
\text { 할랍자 교육환경 개선 } \\
\text { 사업 }\end{array}$ & 프로젝트 & 105.09 & 20.00 & 계속 & $2013-2018$ & 양자무상 & 4 \\
\hline 306 & 이라크(ODA) & $\begin{array}{l}\text { 이라크 KRG 쿠르드 } \\
\text { 공무원교육원(KIPA) } \\
\text { 역량강화지원사업 }\end{array}$ & 프로젝트 & 67.80 & - & 계속 & $2013-2018$ & 양자무상 & 16 \\
\hline 307 & 이라크(ODA) & $\begin{array}{l}\text { 이라크 한-이라크 직 } \\
\text { 업훈련원 } 2 \text { 차 지원사 } \\
\text { 업 }\end{array}$ & 프로젝트 & 56.00 & 25.00 & 계속 & $2014-2018$ & 양자무상 & 4 \\
\hline 308 & 이라크(ODA) & $\begin{array}{l}\text { 이라크 중환자 전문 } \\
\text { 의료센터 건립사업 }\end{array}$ & 프로젝트 & 410.40 & 85.00 & 계속 & $2016-2020$ & 양자무상 & 3 \\
\hline 309 & 이라크(ODA) & $\begin{array}{l}\text { 이라크 국립대학 및 } \\
\text { 정부기관 어학실습실 } \\
\text { 구축사업 }\end{array}$ & 프로젝트 & 78.87 & - & 계속 & $2013-2018$ & 양자무상 & 4 \\
\hline 310 & 이라크(ODA) & $\begin{array}{l}\text { 이라크 쿠르드지방정 } \\
\text { 부 공공조달 현대화 } \\
\text { 사업 }\end{array}$ & 프로젝트 & 66.70 & 1.00 & 신규 & $2018-2021$ & 양자무상 & 12 \\
\hline 311 & 팔레스타인(ODA) & $\begin{array}{l}\text { 팔레스타인 바이오 연 } \\
\text { 구센터 설립사업 }\end{array}$ & 프로젝트 & 33.90 & 3.00 & 계속 & $2013-2018$ & 양자무상 & 9 \\
\hline 312 & 팔레스타인(ODA) & $\begin{array}{l}\text { 팔레스타인 제닌 청소 } \\
\text { 년센터 건립사업 }\end{array}$ & 프로젝트 & 40.68 & - & 계속 & $2013-2018$ & 양자무상 & 4 \\
\hline 313 & 팔레스타인(ODA) & $\begin{array}{l}\text { 팔레스타인 공무원교 } \\
\text { 육원 설립사업 }\end{array}$ & 프로젝트 & 78.40 & 32.00 & 계속 & $2014-2019$ & 양자무상 & 16 \\
\hline 314 & 팔레스타인(ODA) & $\begin{array}{l}\text { 팔레스타인 창.취업 } \\
\text { 지원프로그램 }\end{array}$ & 프로젝트 & 72.10 & 18.00 & 계속 & $2015-2019$ & 양자무상 & 1 \\
\hline 315 & 팔레스타인(ODA) & $\begin{array}{l}\text { KOICA-UNRWA 팔레 } \\
\text { 스타인 가자지구 직업 } \\
\text { 훈련교육 및 실습 프 } \\
\text { 로그램 사업 }\end{array}$ & 프로젝트 & 49.45 & 11.70 & 계속 & $2017-2018$ & 양자무상 & 4 \\
\hline 316 & 팔레스타인(ODA) & \begin{tabular}{|l|} 
팔레스타인 외교부 행 \\
정관리시스템 고도화 \\
및 보안네트워크 구축 \\
사업
\end{tabular} & 프로젝트 & 25.30 & 1.00 & 신규 & $2018-2020$ & 양자무상 & 9 \\
\hline 317 & $\begin{array}{l}\text { 중동CIS지역 비중점 } \\
\text { 국가그룹(ODA) }\end{array}$ & $\begin{array}{l}\text { 요르단 } 3 \text { 개 지역 보건 } \\
\text { 소 건립사업 }\end{array}$ & 프로젝트 & 57.79 & 15.84 & 계속 & $2014-2018$ & 양자무상 & 3 \\
\hline 318 & $\begin{array}{l}\text { 중동CIS지역 비중점 } \\
\text { 국가그룹(ODA) }\end{array}$ & $\begin{array}{l}\text { 요르단 자르카 기술고 } \\
\text { 등학교 설립사업 }\end{array}$ & 프로젝트 & 69.00 & 22.40 & 계속 & $2017-2020$ & 양자무상 & 4 \\
\hline 319 & $\begin{array}{l}\text { 중동CIS지역 비중점 } \\
\text { 국가그룹(ODA) }\end{array}$ & $\begin{array}{l}\text { 요르단 시리아 난민 } \\
\text { 밀집지역 취약계층 아 } \\
\text { 동을 위한 } 4 \text { 개 학교 } \\
\text { 건립사업 }\end{array}$ & 프로젝트 & 127.65 & 23.31 & 계속 & $2017-2020$ & 양자무상 & 4 \\
\hline
\end{tabular}




\begin{tabular}{|c|c|c|c|c|c|c|c|c|c|}
\hline & 세부사업명 & 내역사업명 & 사업 유형 & $\begin{array}{c}\text { 총사업예산 } \\
\text { (억원) }\end{array}$ & $\begin{array}{l}\text { ‘18년예 } \\
\text { 산 (억원) }\end{array}$ & $\begin{array}{l}\text { 신규/ } \\
\text { 계속 }\end{array}$ & $\begin{array}{l}\text { 총사업 } \\
\text { 기간 }\end{array}$ & $\begin{array}{c}\text { 구분 } \\
\text { (양-다자 } \\
\text { ) }\end{array}$ & $\begin{array}{l}\mathrm{SDGS} \\
\text { 목표 }\end{array}$ \\
\hline 320 & $\begin{array}{l}\text { 중동CIS지역 비중점 } \\
\text { 국가그룹(ODA) }\end{array}$ & $\begin{array}{l}\text { 키르기즈공화국 포용적 } \\
\text { 이고 지속가능한 농촌 } \\
\text { 개발 시범사업 }\end{array}$ & 프로젝트 & 40.25 & 9.87 & 계속 & $2017-2020$ & 양자무상 & 1 \\
\hline 321 & $\begin{array}{l}\text { 중동CIS지역 비중점 } \\
\text { 국가그릅(ODA) }\end{array}$ & $\begin{array}{l}\text { 키르기즈공화국 선거 } \\
\text { 역량강화사업 } 2 \text { 차 사 } \\
\text { 업 }\end{array}$ & 프로젝트 & 13.57 & 13.07 & 계속 & $2017-2018$ & 양자무상 & 16 \\
\hline 322 & $\begin{array}{l}\text { 중동CIS지역 비중점 } \\
\text { 국가그룹(ODA) }\end{array}$ & $\begin{array}{l}\text { 투르크메니스탄 가스 } \\
\text { 직업훈련원 역량강화 } \\
\text { 사업 }\end{array}$ & 프로젝트 & 65.27 & 64.02 & 계속 & $2014-2018$ & 양자무상 & 4 \\
\hline 323 & $\begin{array}{l}\text { 중동CIS지역 비중점 } \\
\text { 국가그룹(ODA) }\end{array}$ & $\begin{array}{l}\text { 타지키스탄 소수력 발 } \\
\text { 전 기반 지역개발 프 } \\
\text { 로그램 }\end{array}$ & 프로젝트 & 115.00 & 5.00 & 계속 & $2017-2019$ & 양자무상 & 7 \\
\hline 324 & $\begin{array}{l}\text { 중동CIS지역 비중점 } \\
\text { 국가그룹(ODA) }\end{array}$ & $\begin{array}{l}\text { 이란 국립 직업훈련교 } \\
\text { 사 훈련원 현대화사업 }\end{array}$ & 프로젝트 & 86.25 & 25.80 & 계속 & $2017-2020$ & 양자무상 & 1 \\
\hline 325 & $\begin{array}{l}\text { 중동CIS지역 비중점 } \\
\text { 국가그룹(ODA) }\end{array}$ & $\begin{array}{l}\text { 이란 이스파한 국제공 } \\
\text { 항 신여객터미널 건설 } \\
\text { 타당성조사 및 기본설 } \\
\text { 계 사업 }\end{array}$ & 개발컨설팅 & 51.75 & 1.00 & 계속 & $2017-2018$ & 양자무상 & 1 \\
\hline 326 & $\begin{array}{l}\text { 아프리카지역 비중점 } \\
\text { 국가그룹(ODA) }\end{array}$ & $\begin{array}{l}\text { 이집트 한-이 기술대 } \\
\text { 학 설립사업 }\end{array}$ & 개발컨설팅 & 66.46 & 6.00 & 계속 & $2016-2022$ & 양자무상 & 4 \\
\hline 327 & $\begin{array}{l}\text { 아프리카지역 비중점 } \\
\text { 국가그룹(ODA) }\end{array}$ & \begin{tabular}{|l|} 
모로코 산업통계 측정 \\
및 활용 역량강화사업 \\
\end{tabular} & 프로젝트 & 72.31 & 32.42 & 계속 & $2014-2018$ & 양자무상 & 1 \\
\hline 328 & $\begin{array}{l}\text { 아프리카지역 비중점 } \\
\text { 국가그릅(ODA) }\end{array}$ & $\begin{array}{l}\text { 모로코 세부강 유역 } \\
\text { 홍수방지 마스터플랜 } \\
\text { 수립사업 }\end{array}$ & 개발컨설팅 & 41.20 & 7.00 & 계속 & $2015-2018$ & 양자무상 & 6 \\
\hline 329 & $\begin{array}{l}\text { 아프리카지역 비중점 } \\
\text { 국가그룹(ODA) }\end{array}$ & \begin{tabular}{|l|} 
모로코 녹색기술 연구 \\
개발 종합지원사업
\end{tabular} & 프로젝트 & 92.00 & 20.70 & 계속 & $2017 \sim 2020$ & 양자무상 & 7 \\
\hline 330 & $\begin{array}{l}\text { 아프리카지역 비중점 } \\
\text { 국가그룹(ODA) }\end{array}$ & $\begin{array}{l}\text { 알제리 어업 및 양식 } \\
\text { 생산력의 지속가능한 } \\
\text { 증대 및 산업화 컨설 } \\
\text { 팅사업 }\end{array}$ & 개발컨설팅 & 56.00 & - & 계속 & $2014-2018$ & 양자무상 & 14 \\
\hline 331 & $\begin{array}{l}\text { 아프리카지역 비중점 } \\
\text { 국가그룹(ODA) }\end{array}$ & \begin{tabular}{|l|} 
알제리 새우양식 사료 \\
제조역량 강화 사업
\end{tabular} & 프로젝트 & 33.35 & 1.00 & 신규 & $2018-2020$ & 양자무상 & 14 \\
\hline 332 & $\begin{array}{l}\text { 아프리카지역 비중점 } \\
\text { 국가그룹(ODA) }\end{array}$ & \begin{tabular}{|l|} 
튀니지 코르크 참나무 \\
숲 복원 시범사업
\end{tabular} & 프로젝트 & 22.40 & 3.46 & 계속 & $2014-2018$ & 양자무상 & 15 \\
\hline 333 & $\begin{array}{l}\text { 아프리카지역 비중점 } \\
\text { 국가그룹(ODA) }\end{array}$ & $\begin{array}{l}\text { 튀니지 국민참여 및 } \\
\text { 부패방지를 위한 시스 } \\
\text { 템(국민신문고) 구축 } \\
\text { 사업 }\end{array}$ & 프로젝트 & 51.50 & 3.00 & 계속 & $2015-2018$ & 양자무상 & 16 \\
\hline 334 & $\begin{array}{l}\text { 아프리카지역 비중점 } \\
\text { 국가그륩(ODA) }\end{array}$ & $\begin{array}{l}\text { 튀니지 UNDP 민주적 } \\
\text { 거버넌스 및 공공책임 } \\
\text { 성 강화사업 } \\
\end{array}$ & 프로젝트 & 45.60 & 13.00 & 계속 & $2016-2019$ & 양자무상 & 16 \\
\hline 335 & $\begin{array}{l}\text { 아프리카지역 비중점 } \\
\text { 국가그룹(ODA) }\end{array}$ & \begin{tabular}{|l|} 
튀니지 남부지역 \\
$50 \mathrm{MW}$ 태양광발전소 \\
건설사업 타당성조사 \\
\end{tabular} & 개발컨설팅 & 17.25 & 6.00 & 계속 & $2017-2018$ & 양자무상 & 7 \\
\hline 336 & $\begin{array}{l}\text { 중동CIS지역 비중점 } \\
\text { 국가그릅(ODA) }\end{array}$ & 사업효과성제고비 & 기타 & & 53.50 & 계속 & 2018 & 양자무상 & \\
\hline 337 & $\begin{array}{l}\text { 중동CIS지역 비중점 } \\
\text { 국가그릅(ODA) }\end{array}$ & 소규모무상원조 & 프로젝트 & & 26.00 & 계속 & 2018 & 양자무상 & \\
\hline 338 & $\begin{array}{l}\text { 중동CIS지역 비중점 } \\
\text { 국가그룹(ODA) }\end{array}$ & 사업행정비 & 행정비용 & & 1.71 & 계속 & 2018 & 양자무상 & \\
\hline 339 & $\begin{array}{l}\text { 해외봉사단 및 국제개 } \\
\text { 발협력 인재 양성 } \\
\text { (ODA) }\end{array}$ & $\begin{array}{l}\text { 월드프렌즈 코이카 봉 } \\
\text { 사단 }\end{array}$ & 봉사단파견 & & $1,108.78$ & 계속 & 2018 & 양자무상 & 4 \\
\hline 340 & $\begin{array}{l}\text { 해외봉사단 및 국제개 } \\
\text { 발협력 인재 양성 } \\
\text { (ODA) }\end{array}$ & 월드프렌즈 IT 봉사단 & 봉사단파견 & & 31.52 & 계속 & 2018 & 양자무상 & 4 \\
\hline 341 & $\begin{array}{l}\text { 해외봉사단 및 국제개 } \\
\text { 발협력 인재 양성 } \\
\text { (ODA) }\end{array}$ & $\begin{array}{l}\text { 월드프렌즈 청년 봉사 } \\
\text { 단 }\end{array}$ & 봉사단파견 & & 34.05 & 계속 & 2018 & 양자무상 & 4 \\
\hline
\end{tabular}




\begin{tabular}{|c|c|c|c|c|c|c|c|c|c|}
\hline & 세부사업명 & 내역사업명 & 사업 유형 & $\begin{array}{c}\text { 총사업예산 } \\
\text { (억원) }\end{array}$ & $\begin{array}{l}\text { '18년예 } \\
\text { 산 (억원) }\end{array}$ & $\begin{array}{l}\text { 신규/ } \\
\text { 계속 }\end{array}$ & $\begin{array}{l}\text { 총사업 } \\
\text { 기간 }\end{array}$ & $\begin{array}{c}\text { 구분 } \\
\text { (양-다자 } \\
\text { ) }\end{array}$ & $\begin{array}{l}\text { SDGs } \\
\text { 목표 }\end{array}$ \\
\hline 342 & $\begin{array}{l}\text { 해외봉사단 및 국제개 } \\
\text { 발협력 인재 양성 } \\
\text { (ODA) }\end{array}$ & 월드프렌즈 자문단 & 봉사단파견 & & 151.57 & 계속 & 2018 & 양자무상 & 4 \\
\hline 343 & $\begin{array}{l}\text { 해외봉사단 및 국제개 } \\
\text { 발협력 인재 양성 } \\
\text { (ODA) }\end{array}$ & $\begin{array}{l}\text { 월드프렌즈 과학기술 } \\
\text { 지원단 }\end{array}$ & 봉사단파견 & & 24.45 & 계속 & 2018 & 양자무상 & 4 \\
\hline 344 & $\begin{array}{l}\text { 해외봉사단 및 국제개 } \\
\text { 발협력 인재 양성 } \\
\text { (ODA) }\end{array}$ & 글로벌 협력의료진 & 봉사단파견 & & 50.16 & 계속 & 2018 & 양자무상 & 3 \\
\hline 345 & $\begin{array}{l}\text { 해외봉사단 및 국제개 } \\
\text { 발협력 인재 양성 } \\
\text { (ODA) }\end{array}$ & $\begin{array}{l}\text { 월드프렌즈 영월교육 } \\
\text { 원 } 2 \text { 단계 사업 }\end{array}$ & 봉사단파견 & & 38.90 & 계속 & 2018 & 양자무상 & 4 \\
\hline 346 & $\begin{array}{l}\text { 해외봉사단 및 국제개 } \\
\text { 발협력 인재 양성 } \\
\text { (ODA) }\end{array}$ & ODA 영프로페셔널 & 봉사단파견 & & 156.00 & 계속 & 2018 & 양자무상 & 4 \\
\hline 347 & $\begin{array}{l}\text { 해외봉사단 및 국제개 } \\
\text { 발협력 인재 양성 } \\
\text { (ODA) }\end{array}$ & $\begin{array}{l}\text { KOICA 다자협력전문 } \\
\text { 가 }(\mathrm{KMCO}) \text { 파견사업 }\end{array}$ & 봉사단파견 & & 14.23 & 계속 & 2018 & 양자무상 & 4 \\
\hline 348 & $\begin{array}{l}\text { 해외봉사단 및 국제개 } \\
\text { 발협력 인재 양성 } \\
\text { (ODA) }\end{array}$ & 사업행정비 & 봉사단파견 & & 16.70 & 계속 & 2018 & 양자무상 & \\
\hline 349 & 글로벌연수(ODA) & $\begin{array}{l}\text { 네팔 원조 자원관리 } \\
\text { 역량강화 }\end{array}$ & 연수사업 & 5.10 & 1.70 & 계속 & $2016-2018$ & 양자무상 & 1 \\
\hline 350 & 글로벌연수(ODA) & $\begin{array}{l}\text { 동티모르 외교관 역량 } \\
\text { 강화 }\end{array}$ & 연수사업 & 5.35 & 1.78 & 계속 & $2017-2019$ & 양자무상 & 16 \\
\hline 351 & 글로벌연수(ODA) & $\begin{array}{l}\text { 라오스 ODA 인적개 } \\
\text { 발 역량강화 }\end{array}$ & 연수사업 & 5.10 & 1.70 & 계속 & $2016-2018$ & 양자무상 & 16 \\
\hline 352 & 글로벌연수(ODA) & $\begin{array}{l}\text { 라오스 농촌개발 및 } \\
\text { 빈곤퇴치를 위한 인적 } \\
\text { 역량개발 }\end{array}$ & 연수사업 & 3.40 & 1.70 & 계속 & $2017-2018$ & 양자무상 & 1 \\
\hline 353 & 글로벌연수(ODA) & $\begin{array}{l}\text { 몽골 관세국세정책 역 } \\
\text { 량강화 }\end{array}$ & 연수사업 & 5.10 & 1.70 & 계속 & $2017-2019$ & 양자무상 & 16 \\
\hline 354 & 글로벌연수(ODA) & $\begin{array}{l}\text { 몽골 법률집행 교도관 } \\
\text { 역량강화 }\end{array}$ & 연수사업 & 5.10 & 1.70 & 계속 & $2017-2019$ & 양자무상 & 16 \\
\hline 355 & 글로벌연수(ODA) & 방글라데시 무역진흥 & 연수사업 & 5.10 & 1.70 & 계속 & $2016-2018$ & 양자무상 & 16 \\
\hline 356 & 글로벌연수(ODA) & 방글라데시 식품안전 & 연수사업 & 5.10 & 1.70 & 계속 & $2016-2018$ & 양자무상 & 3 \\
\hline 357 & 글로벌연수(ODA) & $\begin{array}{l}\text { 방글라데시 자폐스펙 } \\
\text { 트럼 장애아 진단 및 } \\
\text { 치료역량 강화 } 2 \text { 차 }\end{array}$ & 연수사업 & 5.10 & 1.70 & 계속 & $2016-2018$ & 양자무상 & 3 \\
\hline 358 & 글로벌연수(ODA) & $\begin{array}{l}\text { 베트남 공산당 경제개 } \\
\text { 발 고위급 인사 역량 } \\
\text { 강화 }\end{array}$ & 연수사업 & 5.10 & 1.70 & 계속 & $2016-2018$ & 양자무상 & 10 \\
\hline 359 & 글로벌연수(ODA) & $\begin{array}{l}\text { 베트남 미래지도자 역 } \\
\text { 량강화(2차) }\end{array}$ & 연수사업 & 5.35 & 1.78 & 계속 & $2017-2019$ & 양자무상 & 16 \\
\hline 360 & 글로벌연수(ODA) & \begin{tabular}{|l|} 
베트남 저널리즘 및 \\
커뮤니케이션 아카데 \\
미(AJC) 정부정책 시 \\
행 역량강화 \\
\end{tabular} & 연수사업 & 5.10 & 1.70 & 계속 & $2016-2018$ & 양자무상 & 16 \\
\hline 361 & 글로벌연수(ODA) & $\begin{array}{l}\text { 베트남 최고인민검찰 } \\
\text { 원 역량강화 }\end{array}$ & 연수사업 & 5.10 & 1.70 & 계속 & $2016-2018$ & 양자무상 & 10 \\
\hline 362 & 글로벌연수(ODA) & $\begin{array}{l}\text { 솔로몬군도 농업분야 } \\
\text { 시장가능성 향상을 위 } \\
\text { 한 연수과정 }\end{array}$ & 연수사업 & 5.10 & 1.70 & 계속 & $2016-2018$ & 양자무상 & 2 \\
\hline 363 & 글로벌연수(ODA) & $\begin{array}{l}\text { 스리랑카 검사 과학수 } \\
\text { 사 역량강화 }\end{array}$ & 연수사업 & 5.35 & 1.78 & 계속 & $2017-2019$ & 양자무상 & 16 \\
\hline 364 & 글로벌연수(ODA) & $\begin{array}{l}\text { 스리랑카 국영방송 프 } \\
\text { 로그램 제작 및 방송 } \\
\text { 역량강화 }\end{array}$ & 연수사업 & 5.10 & 1.70 & 계속 & $2016-2018$ & 양자무상 & 16 \\
\hline 365 & 글로벌연수(ODA) & $\begin{array}{l}\text { 스리랑카 특수교육 교 } \\
\text { 사 역량강화 }\end{array}$ & 연수사업 & 5.10 & 1.70 & 계속 & $2017-2019$ & 양자무상 & 4 \\
\hline
\end{tabular}




\begin{tabular}{|c|c|c|c|c|c|c|c|c|c|}
\hline & 세부사업명 & 내역사업명 & 사업 유형 & $\begin{array}{c}\text { 총사업예산 } \\
\text { (억원) }\end{array}$ & $\begin{array}{l}\text { '18년 예 } \\
\text { 산 (억원) }\end{array}$ & $\begin{array}{l}\text { 신규/ } \\
\text { 계속 }\end{array}$ & $\begin{array}{l}\text { 총사업 } \\
\text { 기간 }\end{array}$ & $\begin{array}{c}\text { 구분 } \\
\text { (양-다자 } \\
\text { ) }\end{array}$ & $\begin{array}{l}\text { SDGs } \\
\text { 목표 }\end{array}$ \\
\hline 366 & 글로벌연수(ODA) & $\begin{array}{l}\text { 아프가니스탄 전자조 } \\
\text { 달시스템 }\end{array}$ & 연수사업 & 5.10 & 1.70 & 계속 & $2016-2018$ & 양자무상 & 16 \\
\hline 367 & 글로벌연수(ODA) & $\begin{array}{l}\text { 아프가니스탄 중환자 } \\
\text { 실 의료인력 역량개발 }\end{array}$ & 연수사업 & 5.10 & 1.70 & 계속 & $2016-2018$ & 양자무상 & 3 \\
\hline 368 & 글로벌연수(ODA) & $\begin{array}{l}\text { 인도네시아 공공감사 } \\
\text { 역량강화 지원 }\end{array}$ & 연수사업 & 5.10 & 1.70 & 계속 & $2016-2018$ & 양자무상 & 16 \\
\hline 369 & 글로벌연수(ODA) & $\begin{array}{l}\text { 인도네시아 국가개발 } \\
\text { 계획 지식공유 }\end{array}$ & 연수사업 & 5.35 & 1.78 & 계속 & $2017-2019$ & 양자무상 & 16 \\
\hline 370 & 글로벌연수(ODA) & $\begin{array}{l}\text { 인도네시아 수도권 통 } \\
\text { 합 해안 종합개발 지 } \\
\text { 식관리 역량강화 }\end{array}$ & 연수사업 & 5.35 & 1.78 & 계속 & $2017-2019$ & 양자무상 & 6 \\
\hline 371 & 글로벌연수(ODA) & $\begin{array}{l}\text { 중국 수출입 식품 위 } \\
\text { 해요소 중점관리 }\end{array}$ & 연수사업 & 8.91 & 1.78 & 계속 & $2015-2019$ & 양자무상 & 3 \\
\hline 372 & 글로벌연수(ODA) & $\begin{array}{l}\text { 캄보디아 교원연수 전 } \\
\text { 략개발 및 운영 역량 } \\
\text { 강화 }\end{array}$ & 연수사업 & 5.10 & 1.70 & 계속 & $2017-2019$ & 양자무상 & 4 \\
\hline 373 & 글로벌연수(ODA) & $\begin{array}{l}\text { 파키스탄경제개발전략 } \\
\text { 역량강화 }\end{array}$ & 연수사업 & 5.10 & 1.70 & 계속 & $2016-2018$ & 양자무상 & 10 \\
\hline 374 & 글로벌연수(ODA) & $\begin{array}{l}\text { 필리핀 검찰 과학수사 } \\
\text { 역량강화 }\end{array}$ & 연수사업 & 5.10 & 1.70 & 계속 & $2016-2018$ & 양자무상 & 16 \\
\hline 375 & 글로벌연수(ODA) & $\begin{array}{l}\text { 필리핀 기상수치예보 } \\
\text { 자료 가공 역량강화 }\end{array}$ & 연수사업 & 5.10 & 1.70 & 계속 & $2016-2018$ & 양자무상 & 16 \\
\hline 376 & 글로벌연수(ODA) & $\begin{array}{l}\text { DR콩고 국립박물관 } \\
\text { 운영 역량강화 }\end{array}$ & 연수사업 & 4.86 & 1.62 & 계속 & $2017-2019$ & 양자무상 & 16 \\
\hline 377 & 글로벌연수(ODA) & DR콩고사법역량강화 & 연수사업 & 4.86 & 1.62 & 계속 & $2016-2018$ & 양자무상 & 16 \\
\hline 378 & 글로벌연수(ODA) & $\begin{array}{l}\mathrm{DR} \text { 콩고 행정발전 역 } \\
\text { 량강화(고위급) }\end{array}$ & 연수사업 & 4.86 & 1.62 & 계속 & $2017-2019$ & 양자무상 & 16 \\
\hline 379 & 글로벌연수(ODA) & $\begin{array}{l}\text { 가나 개발협력 역량강 } \\
\text { 화 }\end{array}$ & 연수사업 & 6.48 & 3.24 & 계속 & $2017-2018$ & 양자무상 & 17 \\
\hline 380 & 글로벌연수(ODA) & $\begin{array}{l}\text { 가나 성과기반 공공인 } \\
\text { 사관리시스템 구축과 } \\
\text { 정 (실무급) }\end{array}$ & 연수사업 & 4.86 & 1.62 & 계속 & $2017-2019$ & 양자무상 & 16 \\
\hline 381 & 글로벌연수(ODA) & $\begin{array}{l}\text { 나이지리아 농촌개발 } \\
\text { 역량강화 }\end{array}$ & 연수사업 & 4.86 & 1.62 & 계속 & $2016-2018$ & 양자무상 & 2 \\
\hline 382 & 글로벌연수(ODA) & $\begin{array}{l}\text { 르완다관개및농지개발 } \\
\text { 및유지관리역량강화 }\end{array}$ & 연수사업 & 4.86 & 1.62 & 계속 & $2017-2019$ & 양자무상 & 2 \\
\hline 383 & 글로벌연수(ODA) & $\begin{array}{l}\text { 모로코 효율적 사법제 } \\
\text { 도 및 운영개선 }\end{array}$ & 연수사업 & 4.86 & 1.62 & 계속 & $2016-2018$ & 양자무상 & 16 \\
\hline 384 & 글로벌연수(ODA) & $\begin{array}{l}\text { 모잠비크 지역개발 정 } \\
\text { 책 역량강화 }\end{array}$ & 연수사업 & 4.86 & 1.62 & 계속 & $2016-2018$ & 양자무상 & 16 \\
\hline 385 & 글로벌연수(ODA) & $\begin{array}{l}\text { 모잠비크 투자무역 촉 } \\
\text { 진 역량강화 }\end{array}$ & 연수사업 & 4.86 & 1.62 & 계속 & $2016-2018$ & 양자무상 & 16 \\
\hline 386 & 글로벌연수(ODA) & $\begin{array}{l}\text { 세네갈 모자보건 및 } \\
\text { 의료시스템 역량강화 }\end{array}$ & 연수사업 & 4.86 & 1.62 & 계속 & $2017-2019$ & 양자무상 & 3 \\
\hline 397 & 글로벌연수(ODA) & $\begin{array}{l}\text { 에티오피아헌법및민주 } \\
\text { 주의발전을위한역량강 } \\
\text { 화 }\end{array}$ & 연수사업 & 4.86 & 1.62 & 계속 & $2016-2018$ & 양자무상 & 16 \\
\hline 388 & 글로벌연수(ODA) & $\begin{array}{l}\text { 이집트 지하철 운영역 } \\
\text { 량강화 }\end{array}$ & 연수사업 & 4.86 & 1.62 & 계속 & $2016-2018$ & 양자무상 & 9 \\
\hline 389 & 글로벌연수(ODA) & $\begin{array}{l}\text { 이집트 철도운영 역량 } \\
\text { 강화 }\end{array}$ & 연수사업 & 4.86 & 1.62 & 계속 & $2016-2018$ & 양자무상 & 9 \\
\hline 390 & 글로벌연수(ODA) & $\begin{array}{l}\text { 케냐공항청고객만족을 } \\
\text { 위한역량강화 }\end{array}$ & 연수사업 & 4.86 & 1.62 & 계속 & $2017-2019$ & 양자무상 & 16 \\
\hline 391 & 글로벌연수(ODA) & $\begin{array}{l}\text { 탄자니아 농업기술교 } \\
\text { 육센터 트레이닝 양성 }\end{array}$ & 연수사업 & 4.86 & 1.62 & 계속 & $2017-2019$ & 양자무상 & 2 \\
\hline 392 & 글로벌연수(ODA) & $\begin{array}{l}\text { 탄자니아 수혈 서비스 } \\
\text { 제공 역량 강화 }\end{array}$ & 연수사업 & 4.86 & 1.62 & 계속 & $2016-2018$ & 양자무상 & 3 \\
\hline 393 & 글로벌연수(ODA) & $\begin{array}{l}\text { 탄자니아 중등학교 교 } \\
\text { 장 학교 관리 역량 강 } \\
\text { 화 }\end{array}$ & 연수사업 & 4.86 & 1.62 & 계속 & $2016-2018$ & 양자무상 & 4 \\
\hline
\end{tabular}




\begin{tabular}{|c|c|c|c|c|c|c|c|c|c|}
\hline & 세부사업명 & 내역사업명 & 사업 유형 & $\begin{array}{c}\text { 총사업예산 } \\
\text { (억원) }\end{array}$ & $\begin{array}{l}\text { ‘18년예 } \\
\text { 산 (억원) }\end{array}$ & $\begin{array}{l}\text { 신규/ } \\
\text { 계속 }\end{array}$ & $\begin{array}{l}\text { 총사업 } \\
\text { 기간 }\end{array}$ & $\begin{array}{c}\text { 구분 } \\
\text { (양-다자 } \\
\text { ) }\end{array}$ & $\begin{array}{l}\mathrm{SDGS} \\
\text { 목표 }\end{array}$ \\
\hline 394 & 글로벌연수(ODA) & $\begin{array}{l}\text { 튀니지 공공부문개혁 } \\
\text { 을 위한 공무원 역량 } \\
\text { 강화 }\end{array}$ & 연수사업 & 4.86 & 1.62 & 계속 & $2017-2019$ & 양자무상 & 16 \\
\hline 395 & 글로벌연수(ODA) & $\begin{array}{l}\text { 튀니지 사이버범죄 대 } \\
\text { 응 역량강화 }\end{array}$ & 연수사업 & 4.86 & 1.62 & 계속 & $2016-2018$ & 양자무상 & 16 \\
\hline 396 & 글로벌연수(ODA) & $\begin{array}{l}\text { 튀니지 인프라(도로 } \\
\text { 및 교량) 기획 및 건 } \\
\text { 설 역량강화 } \\
\end{array}$ & 연수사업 & 4.86 & 1.62 & 계속 & $2016-2018$ & 양자무상 & 9 \\
\hline 397 & 글로벌연수(ODA) & $\begin{array}{l}\text { 튀니지 철도운영 역량 } \\
\text { 강화 }\end{array}$ & 연수사업 & 5.35 & 1.78 & 계속 & $2017-2019$ & 양자무상 & 11 \\
\hline 398 & 글로벌연수(ODA) & $\begin{array}{l}\text { 도미니카공화국 } 911 \\
\text { 응급안전시스템 운영 } \\
\text { 자 역량강화 }\end{array}$ & 연수사업 & 4.86 & 1.62 & 계속 & $2016-2018$ & 양자무상 & 3 \\
\hline 399 & 글로벌연수(ODA) & $\begin{array}{l}\text { 볼리비아광업에따른환 } \\
\text { 경오염감소를위한정책 }\end{array}$ & 연수사업 & 4.86 & 1.62 & 계속 & $2016-2018$ & 양자무상 & 15 \\
\hline 400 & 글로벌연수(ODA) & $\begin{array}{l}\text { 에콰도르 중등교육의 } \\
\text { 형평성 제고를 위한 } \\
\text { 정책 }\end{array}$ & 연수사업 & 4.86 & 1.62 & 계속 & $2016-2018$ & 양자무상 & 4 \\
\hline 401 & 글로벌연수(ODA) & $\begin{array}{l}\text { 엘살바도르 행정발전 } \\
\text { 경험 공유 }\end{array}$ & 연수사업 & 4.86 & 1.62 & 계속 & $2016-2018$ & 양자무상 & 16 \\
\hline 402 & 글로벌연수(ODA) & $\begin{array}{l}\text { 온두라스치안및경찰역 } \\
\text { 량강화 }\end{array}$ & 연수사업 & 4.86 & 1.62 & 계속 & $2016-2018$ & 양자무상 & 16 \\
\hline 403 & 글로벌연수(ODA) & \begin{tabular}{|l|} 
콜롬비아의약품의설 \\
계,생산,품질관리기술
\end{tabular} & 연수사업 & 4.86 & 1.62 & 계속 & $2016-2018$ & 양자무상 & 9 \\
\hline 404 & 글로벌연수(ODA) & $\begin{array}{l}\text { 파라과이 철도 건설 } \\
\text { 및 관리 역량강화 }\end{array}$ & 연수사업 & 3.24 & 1.62 & 계속 & $2017-2018$ & 양자무상 & 9 \\
\hline 405 & 글로벌연수(ODA) & $\begin{array}{l}\text { 파라과이 환경보호 및 } \\
\text { 관리 역량강화 }\end{array}$ & 연수사업 & 4.86 & 1.62 & 계속 & $2016-2018$ & 양자무상 & 15 \\
\hline 406 & 글로벌연수(ODA) & 페루 전자정부 구축 & 연수사업 & 3.24 & 1.62 & 계속 & $2017-2018$ & 양자무상 & 16 \\
\hline 407 & 글로벌연수(ODA) & $\begin{array}{l}\text { 페루 지방정부 행정 } \\
\text { 역량강화 }\end{array}$ & 연수사업 & 4.86 & 1.62 & 계속 & $2016-2018$ & 양자무상 & 16 \\
\hline 408 & 글로벌연수(ODA) & $\begin{array}{l}\text { 아제르바이잔 공공서 } \\
\text { 비스 및 사회혁신 역 } \\
\text { 량강화 }\end{array}$ & 연수사업 & 4.86 & 1.62 & 계속 & $2017-2019$ & 양자무상 & 16 \\
\hline 409 & 글로벌연수(ODA) & $\begin{array}{l}\text { 아제르바이잔 세무행 } \\
\text { 정 실행 역량강화 }\end{array}$ & 연수사업 & 3.24 & 1.62 & 계속 & $2017-2018$ & 양자무상 & 16 \\
\hline 410 & 글로벌연수(ODA) & $\begin{array}{l}\text { 요르단 수자원 개발 } \\
\text { 및 관리 }\end{array}$ & 연수사업 & 4.86 & 1.62 & 계속 & $2017-2019$ & 양자무상 & 6 \\
\hline 411 & 글로벌연수(ODA) & $\begin{array}{l}\text { 요르단 전자정부 정보 } \\
\text { 기술설계 }\end{array}$ & 연수사업 & 3.24 & 1.62 & 계속 & $2017-2018$ & 양자무상 & 16 \\
\hline 412 & 글로벌연수(ODA) & $\begin{array}{l}\text { 우즈베키스탄 금융 및 } \\
\text { 예산 기획 전문가 역 } \\
\text { 량강화 }\end{array}$ & 연수사업 & 4.86 & 1.62 & 계속 & $2016-2018$ & 양자무상 & 16 \\
\hline 413 & 글로벌연수(ODA) & $\begin{array}{l}\text { 우즈베키스탄 선임연 } \\
\text { 구원 및 중간관리자를 } \\
\text { 위한 ICT 역량강화 }\end{array}$ & 연수사업 & 4.86 & 1.62 & 계속 & $2017-2019$ & 양자무상 & 9 \\
\hline 414 & 글로벌연수(ODA) & $\begin{array}{l}\text { 이라크 개발 및 전략 } \\
\text { 기획 역량강화 }\end{array}$ & 연수사업 & 4.86 & 1.62 & 계속 & $2016-2018$ & 양자무상 & 16 \\
\hline 415 & 글로벌연수(ODA) & $\begin{array}{l}\text { 이라크 범죄예방 및 } \\
\text { 대테러 역량강화 }\end{array}$ & 연수사업 & 4.86 & 1.62 & 계속 & $2017-2019$ & 양자무상 & 16 \\
\hline 416 & 글로벌연수(ODA) & $\begin{array}{l}\text { 이라크 에너지효율등 } \\
\text { 급 제도구축 및 표준 } \\
\text { 체계 역량강화 }\end{array}$ & 연수사업 & 5.35 & 1.78 & 계속 & $2017-2019$ & 양자무상 & 7 \\
\hline 417 & 글로벌연수(ODA) & $\begin{array}{l}\text { 이라크 전자정부 역량 } \\
\text { 강화 }\end{array}$ & 연수사업 & 4.86 & 1.62 & 계속 & $2017-2019$ & 양자무상 & 16 \\
\hline 418 & 글로벌연수(ODA) & $\begin{array}{l}\text { 팔레스타인재난대응및 } \\
\text { 관리역량강화 }\end{array}$ & 연수사업 & 4.86 & 1.62 & 계속 & $2017-2019$ & 양자무상 & 11 \\
\hline 419 & 글로벌연수(ODA) & $\begin{array}{l}\text { 네팔 } \mathrm{e} \text {-거버넌스와 } \\
\text { ICT 트레이닝 }\end{array}$ & 연수사업 & 5.35 & 1.78 & 신규 & $2018-2020$ & 양자무상 & 16 \\
\hline 420 & 글로벌연수(ODA) & $\begin{array}{l}\text { 네팔 선거관리 역량강 } \\
\text { 화 }\end{array}$ & 연수사업 & 5.35 & 1.78 & 신규 & $2018-2020$ & 양자무상 & 16 \\
\hline
\end{tabular}




\begin{tabular}{|c|c|c|c|c|c|c|c|c|c|}
\hline & 세부사업명 & 내역사업명 & 사업 유형 & $\begin{array}{c}\text { 총사업예산 } \\
\text { (억원) }\end{array}$ & $\begin{array}{l}\text { '18년예 } \\
\text { 산 (억원) }\end{array}$ & $\begin{array}{l}\text { 신규/ } \\
\text { 계속 }\end{array}$ & $\begin{array}{l}\text { 총사업 } \\
\text { 기간 }\end{array}$ & $\begin{array}{c}\text { 구분 } \\
\text { (양-다자 } \\
\text { ) }\end{array}$ & $\begin{array}{l}\mathrm{SDGS} \\
\text { 목표 }\end{array}$ \\
\hline 421 & 글로벌연수(ODA) & $\begin{array}{l}\text { 라오스 노동조사 역량 } \\
\text { 강화 }\end{array}$ & 연수사업 & 5.35 & 1.78 & 신규 & $2018-2020$ & 양자무상 & 16 \\
\hline 422 & 글로벌연수(ODA) & $\begin{array}{l}\text { 몽골 검찰 형사사법 } \\
\text { 역량강화 }\end{array}$ & 연수사업 & 5.59 & 1.86 & 신규 & $2018-2020$ & 양자무상 & 16 \\
\hline 423 & 글로벌연수(ODA) & $\begin{array}{l}\text { 몽골 중고등교육 교과 } \\
\text { 과정 기준수립 }\end{array}$ & 연수사업 & 5.59 & 1.86 & 신규 & $2018-2020$ & 양자무상 & 4 \\
\hline 424 & 글로벌연수(ODA) & $\begin{array}{l}\text { 방글라데시 섬유의류 } \\
\text { 산업분야 보건안전 } \\
(\mathrm{OSH}) \text { 역량강화 }\end{array}$ & 연수사업 & 5.59 & 1.86 & 신규 & $2018-2020$ & 양자무상 & 3 \\
\hline 425 & 글로벌연수(ODA) & $\begin{array}{l}\text { 베트남 범죄예방 및 } \\
\text { 수사 역량강화 }\end{array}$ & 연수사업 & 5.59 & 1.86 & 신규 & $2018-2020$ & 양자무상 & 16 \\
\hline 426 & 글로벌연수(ODA) & $\begin{array}{l}\text { 부탄 영화산업 역량강 } \\
\text { 화 }\end{array}$ & 연수사업 & 5.35 & 1.78 & 신규 & $2018-2020 \mid$ & 양자무상 & 16 \\
\hline 427 & 글로벌연수(ODA) & $\begin{array}{l}\text { 스리랑카주택개발역량 } \\
\text { 강화 }\end{array}$ & 연수사업 & 5.59 & 1.86 & 신규 & $2018-2020$ & 양자무상 & 11 \\
\hline 428 & 글로벌연수(ODA) & $\begin{array}{l}\text { 스리랑카 천연가스산 } \\
\text { 업 기술개발 }\end{array}$ & 연수사업 & 5.59 & 1.86 & 신규 & $2018-2020$ & 양자무상 & 7 \\
\hline 429 & 글로벌연수(ODA) & $\begin{array}{l}\text { 아프가니스탄 경제기 } \\
\text { 획 역량강화 }\end{array}$ & 연수사업 & 5.35 & 1.78 & 신규 & $2018-2020$ & 양자무상 & 8 \\
\hline 430 & 글로벌연수(ODA) & $\begin{array}{l}\text { 아프가니스탄 국립병 } \\
\text { 원 모자보건 역량강화 }\end{array}$ & 연수사업 & 5.35 & 1.78 & 신규 & $2018-2020$ & 양자무상 & 3 \\
\hline 431 & 글로벌연수(ODA) & $\begin{array}{l}\text { 아프가니스탄 여성 경 } \\
\text { 제역량강화 }\end{array}$ & 연수사업 & 5.35 & 1.78 & 신규 & $2018-2020$ & 양자무상 & 5 \\
\hline 432 & 글로벌연수(ODA) & $\begin{array}{l}\text { 인도네시아 내각 정책 } \\
\text { 리더십 }\end{array}$ & 연수사업 & 5.59 & 1.86 & 신규 & $2018-2020$ & 양자무상 & 16 \\
\hline 433 & 글로벌연수(ODA) & $\begin{array}{l}\text { 캄보디아 개발사업 모 } \\
\text { 니터링 및 평가 역량 } \\
\text { 강화 }\end{array}$ & 연수사업 & 5.59 & 1.86 & 신규 & $2018-2020$ & 양자무상 & 16 \\
\hline 434 & 글로벌연수(ODA) & $\begin{array}{l}\text { 파키스탄 공정경쟁 역 } \\
\text { 량강화 } \\
\end{array}$ & 연수사업 & 5.59 & 1.86 & 신규 & $2018-2020$ & 양자무상 & 8 \\
\hline 435 & 글로벌연수(ODA) & $\begin{array}{l}\text { 파키스탄 펀자브주 운 } \\
\text { 송시스템 운영효율화 }\end{array}$ & 연수사업 & 5.59 & 1.86 & 신규 & $2018-2020$ & 양자무상 & 11 \\
\hline 436 & 글로벌연수(ODA) & $\begin{array}{l}\text { 필리핀 고등교육 정책 } \\
\text { 역량강화 }\end{array}$ & 연수사업 & 11.18 & 3.73 & 신규 & $2018-2020$ & 양자무상 & 4 \\
\hline 437 & 글로벌연수(ODA) & $\begin{array}{l}\text { 필리핀 의료보험 제도 } \\
\text { 개선 }\end{array}$ & 연수사업 & 5.59 & 1.86 & 신규 & $2018-2020$ & 양자무상 & 3 \\
\hline 438 & 글로벌연수(ODA) & $\begin{array}{l}\text { 르완다 정책개발 및 } \\
\text { 조정 역량강화 }\end{array}$ & 연수사업 & 5.59 & 1.86 & 신규 & $2018-2020$ & 양자무상 & 16 \\
\hline 439 & 글로벌연수(ODA) & $\begin{array}{l}\text { 르완다 천연자원 및 } \\
\text { 에너지 연구 역량강화 } \\
\text { 사업 }\end{array}$ & 연수사업 & 5.59 & 1.86 & 신규 & $2018-2020$ & 양자무상 & 7 \\
\hline 440 & 글로벌연수(ODA) & $\begin{array}{l}\text { 모로코-아프리카 문화 } \\
\text { 외교와 소프트파워 삼 } \\
\text { 각협력 }\end{array}$ & 연수사업 & 5.35 & 1.78 & 신규 & $2018-2020$ & 양자무상 & 17 \\
\hline 441 & 글로벌연수(ODA) & $\begin{array}{l}\text { 모로코-아프리카 직업 } \\
\text { 훈련 삼각협력 }\end{array}$ & 연수사업 & 5.35 & 1.78 & 신규 & $2018-2020$ & 양자무상 & 4 \\
\hline 442 & 글로벌연수(ODA) & $\begin{array}{l}\text { 세네갈 ICT 정책 역 } \\
\text { 량강화 }\end{array}$ & 연수사업 & 5.59 & 1.86 & 신규 & $2018-2020$ & 양자무상 & 9 \\
\hline 443 & 글로벌연수(ODA) & $\begin{array}{l}\text { 알제리 수자원 관리 } \\
\text { 역량 강화 }\end{array}$ & 연수사업 & 5.35 & 1.78 & 신규 & $2018-2020$ & 양자무상 & 6 \\
\hline 444 & 글로벌연수(ODA) & $\begin{array}{l}\text { 에티오피아 제조업 전 } \\
\text { 략역량강화 }\end{array}$ & 연수사업 & 3.73 & 1.86 & 신규 & $2018-2019$ & 양자무상 & 8 \\
\hline 445 & 글로벌연수(ODA) & $\begin{array}{l}\text { 우간다 보건의료행정 } \\
\text { 역량강화 }\end{array}$ & 연수사업 & 5.59 & 1.86 & 신규 & $2018-2020$ & 양자무상 & 3 \\
\hline 446 & 글로벌연수(ODA) & $\begin{array}{l}\text { 우간다 직업훈련 역량 } \\
\text { 강화 } \\
\end{array}$ & 연수사업 & 5.59 & 1.86 & 신규 & $2018-2020$ & 양자무상 & 4 \\
\hline 447 & 글로벌연수(ODA) & $\begin{array}{l}\text { 이집트 교육방송 컨텐 } \\
\text { 츠 제작 역량강화 }\end{array}$ & 연수사업 & 5.35 & 1.78 & 신규 & $2018-2020$ & 양자무상 & 4 \\
\hline 448 & 글로벌연수(ODA) & $\begin{array}{l}\text { 카메룬 경제개발전략 } \\
\text { 역량강화 }\end{array}$ & 연수사업 & 5.35 & 1.78 & 신규 & $2018-2020$ & 양자무상 & 8 \\
\hline
\end{tabular}




\begin{tabular}{|c|c|c|c|c|c|c|c|c|c|}
\hline & 세부사업명 & 내역사업명 & 사업 유형 & $\begin{array}{c}\text { 총사업예산 } \\
\text { (억원) }\end{array}$ & $\begin{array}{l}\text { '18년 예 } \\
\text { 산 (억원) }\end{array}$ & $\begin{array}{l}\text { 신규/ } \\
\text { 계속 }\end{array}$ & $\begin{array}{l}\text { 총사업 } \\
\text { 기간 }\end{array}$ & $\begin{array}{c}\text { 구분 } \\
\text { (양-다자 } \\
\text { ) }\end{array}$ & $\begin{array}{l}\mathrm{SDGS} \\
\text { 목표 }\end{array}$ \\
\hline 449 & 글로벌연수(ODA) & $\begin{array}{l}\text { 카메룬 원조자원관리 } \\
\text { 역량강화 }\end{array}$ & 연수사업 & 5.35 & 1.78 & 신규 & $2018-2020 \mid$ & 양자무상 & 8 \\
\hline 450 & 글로벌연수(ODA) & $\begin{array}{l}\text { 케냐 공공서비스 생산 } \\
\text { 성 향상을 위한 공무 } \\
\text { 원 역량강화 }\end{array}$ & 연수사업 & 5.35 & 1.78 & 신규 & $2018-2020$ & 양자무상 & 16 \\
\hline 451 & 글로벌연수(ODA) & $\begin{array}{l}\text { 케냐 병원 운영 역량 } \\
\text { 강화 }\end{array}$ & 연수사업 & 5.35 & 1.78 & 신규 & $2018-2020$ & 양자무상 & 3 \\
\hline 452 & 글로벌연수(ODA) & $\begin{array}{l}\text { 탄자니아 공항시스템 } \\
\text { 역량강화 }\end{array}$ & 연수사업 & 5.59 & 1.86 & 신규 & $2018-2020$ & 양자무상 & 11 \\
\hline 453 & 글로벌연수(ODA) & $\begin{array}{l}\text { 탄자니아 지방행정 역 } \\
\text { 량강화 }\end{array}$ & 연수사업 & 5.59 & 1.86 & 신규 & $2018-2020$ & 양자무상 & 11 \\
\hline 454 & 글로벌연수(ODA) & $\begin{array}{l}\text { 과테말라 경찰교육 역 } \\
\text { 량강화 }\end{array}$ & 연수사업 & 5.35 & 1.78 & 신규 & $2018-2020$ & 양자무상 & 16 \\
\hline 455 & 글로벌연수(ODA) & $\begin{array}{l}\text { 도미니카 공화국 혁신 } \\
\text { 기업가 역량강화 }\end{array}$ & 연수사업 & 5.35 & 1.78 & 신규 & $2018-2020$ & 양자무상 & 8 \\
\hline 456 & 글로벌연수(ODA) & $\begin{array}{l}\text { 볼리비아 기후변화 대 } \\
\text { 응 관개 시스템 기술 }\end{array}$ & 연수사업 & 5.35 & 1.78 & 신규 & $2018-2020$ & 양자무상 & 13 \\
\hline 457 & 글로벌연수(ODA) & $\begin{array}{l}\text { 에콰도르 도시 고형 } \\
\text { 페자원 관리 }\end{array}$ & 연수사업 & 5.35 & 1.78 & 신규 & $2018-2020$ & 양자무상 & 12 \\
\hline 458 & 글로벌연수(ODA) & $\begin{array}{l}\text { 콜롬비아 중소기업의 } \\
\text { 혁신 및 국제 경쟁력 } \\
\text { 강화 }\end{array}$ & 연수사업 & 5.35 & 1.78 & 신규 & $2018-2020$ & 양자무상 & 8 \\
\hline 459 & 글로벌연수(ODA) & $\begin{array}{l}\text { 아제르바이잔 수의제 } \\
\text { 조물 및 식품생산 품 } \\
\text { 질관리역량강화 }\end{array}$ & 연수사업 & 3.56 & 1.78 & 신규 & $2018-2019$ & 양자무상 & 3 \\
\hline 460 & 글로벌연수(ODA) & $\begin{array}{l}\text { 요르단 지역개발 계획 } \\
\text { 수립 }\end{array}$ & 연수사업 & 5.35 & 1.78 & 신규 & $2018-2020$ & 양자무상 & 11 \\
\hline 461 & 글로벌연수(ODA) & $\begin{array}{l}\text { 이라크(바그다드) 농 } \\
\text { 축산 방역 역량강화 }\end{array}$ & 연수사업 & 5.35 & 1.78 & 신규 & $2018-2020$ & 양자무상 & 15 \\
\hline 462 & 글로벌연수(ODA) & $\begin{array}{l}\text { 이라크(바그다드) 병 } \\
\text { 원 관리 역량강화 }\end{array}$ & 연수사업 & 5.35 & 1.78 & 신규 & $2018-2020$ & 양자무상 & 3 \\
\hline 463 & 글로벌연수(ODA) & $\begin{array}{l}\text { 이라크(아르빌) 출입 } \\
\text { 국관리 역량강화 }\end{array}$ & 연수사업 & 5.35 & 1.78 & 신규 & $2018-2020$ & 양자무상 & 10 \\
\hline 464 & 글로벌연수(ODA) & $\begin{array}{l}\text { 키르기즈스탄 공공분 } \\
\text { 야 인적자원관리 }\end{array}$ & 연수사업 & 5.35 & 1.78 & 신규 & $2018-2020$ & 양자무상 & 16 \\
\hline 465 & 글로벌연수(ODA) & $\begin{array}{l}\text { 팔레스타인지리정보시 } \\
\text { 스템 및 원격탐사 역 } \\
\text { 량강화 }\end{array}$ & 연수사업 & 5.35 & 1.78 & 신규 & $2018-2020$ & 양자무상 & 9 \\
\hline 466 & 글로벌연수(ODA) & \begin{tabular}{|l|} 
중남미 기후변화대응 \\
을 위한 산림복합경영
\end{tabular} & 연수사업 & 4.86 & 1.62 & 계속 & $2016-2018$ & 양자무상 & 13 \\
\hline 467 & 글로벌연수(ODA) & $\begin{array}{l}\text { 아프리카 도로운영 및 } \\
\text { 유지관리 }\end{array}$ & 연수사업 & 4.86 & 1.62 & 계속 & $2016-2018$ & 양자무상 & 9 \\
\hline 468 & 글로벌연수(ODA) & CIS 과학수사역량강화 & 연수사업 & 4.86 & 1.62 & 계속 & $2016-2018$ & 양자무상 & 16 \\
\hline 469 & 글로벌연수(ODA) & $\begin{array}{l}\text { 창의발명교육 교원양 } \\
\text { 성 }\end{array}$ & 연수사업 & 4.86 & 1.62 & 계속 & $2016-2018$ & 양자무상 & 4 \\
\hline 470 & 글로벌연수(ODA) & 공공감사 관리 & 연수사업 & 4.86 & 1.62 & 계속 & $2016-2018$ & 양자무상 & 16 \\
\hline 471 & 글로벌연수(ODA) & (아산) 농업개발 과정 & 연수사업 & 4.86 & 1.62 & 계속 & $2016-2018$ & 양자무상 & 2 \\
\hline 472 & 글로벌연수(ODA) & 전통의학의 현대화 & 연수사업 & 4.86 & 1.62 & 계속 & $2016-2018$ & 양자무상 & 3 \\
\hline 473 & 글로벌연수(ODA) & 의약품 안전 & 연수사업 & 4.86 & 1.62 & 계속 & $2016-2018$ & 양자무상 & 3 \\
\hline 474 & 글로벌연수(ODA) & $\begin{array}{l}\text { (전남) 친환경 농업기 } \\
\text { 술 }\end{array}$ & 연수사업 & 4.86 & 1.62 & 계속 & $2016-2018$ & 양자무상 & 2 \\
\hline 475 & 글로벌연수(ODA) & \begin{tabular}{l|} 
품종보호제도및DUS심 \\
사기술역량강화
\end{tabular} & 연수사업 & 4.86 & 1.62 & 계속 & $2016-2018$ & 양자무상 & 2 \\
\hline 476 & 글로벌연수(ODA) & $\begin{array}{l}\text { 기후변화대응 국토개 } \\
\text { 발정책 역량강화 }\end{array}$ & 연수사업 & 4.86 & 1.62 & 계속 & $2016-2018$ & 양자무상 & 13 \\
\hline 477 & 글로벌연수(ODA) & $\begin{array}{l}\text { 농촌개발분야 역량강 } \\
\text { 화전략 }\end{array}$ & 연수사업 & 4.86 & 1.62 & 계속 & $2016-2018$ & 양자무상 & 1 \\
\hline 478 & 글로벌연수(ODA) & $\begin{array}{l}\text { 사법의 공정성과 사법 } \\
\text { 행정의 효율성 제고를 } \\
\text { 위한 파트너쉽 }\end{array}$ & 연수사업 & 4.86 & 1.62 & 계속 & $2016-2018$ & 양자무상 & 16 \\
\hline
\end{tabular}




\begin{tabular}{|c|c|c|c|c|c|c|c|c|c|}
\hline & 세부사업명 & 내역사업명 & 사업 유형 & $\begin{array}{c}\text { 총사업예산 } \\
\text { (억원) }\end{array}$ & $\begin{array}{l}\text { '18년 예 } \\
\text { 산 (억원) }\end{array}$ & $\begin{array}{l}\text { 신규/ } \\
\text { 계속 }\end{array}$ & $\begin{array}{l}\text { 총사업 } \\
\text { 기간 }\end{array}$ & $\begin{array}{c}\text { 구분 } \\
\text { (양-다자 } \\
\text { ) }\end{array}$ & $\begin{array}{l}\text { SDGs } \\
\text { 목표 }\end{array}$ \\
\hline 479 & 글로벌연수(ODA) & $\begin{array}{l}\text { 노사상생지원을 위한 } \\
\text { 정부 역량 강화 }\end{array}$ & 연수사업 & 4.86 & 1.62 & 계속 & $2016-2018$ & 양자무상 & 8 \\
\hline 480 & 글로벌연수(ODA) & $\begin{array}{l}\text { 여성인권 및 여성정책 } \\
\text { 개발 역량강화 }\end{array}$ & 연수사업 & 4.86 & 1.62 & 계속 & $2016-2018$ & 양자무상 & 5 \\
\hline 481 & 글로벌연수(ODA) & $\begin{array}{l}\text { (강원도) 지역개발 활 } \\
\text { 성화 역량강화 }\end{array}$ & 연수사업 & 4.86 & 1.62 & 계속 & $2016-2018$ & 양자무상 & 1 \\
\hline 482 & 글로벌연수(ODA) & $\begin{array}{l}\text { 대형재난 긴급구조 대 } \\
\text { 응 }\end{array}$ & 연수사업 & 4.86 & 1.62 & 계속 & $2016-2018$ & 양자무상 & 11 \\
\hline 483 & 글로벌연수(ODA) & $\begin{array}{l}\text { 지속가능한 발전을 위 } \\
\text { 한 폐기물 관리 및 자 } \\
\text { 원순환형 사회 구축 } \\
\text { 역량강화 }\end{array}$ & 연수사업 & 4.86 & 1.62 & 계속 & $2016-2018$ & 양자무상 & 1 \\
\hline 484 & 글로벌연수(ODA) & $\begin{array}{l}\text { 관세행정 현대화를 통 } \\
\text { 한 무역원활화 }\end{array}$ & 연수사업 & 4.86 & 1.62 & 계속 & $2016-2018$ & 양자무상 & 16 \\
\hline 485 & 글로벌연수(ODA) & $\begin{array}{l}\text { 아시아 해양경찰의 해 } \\
\text { 양치안 행정역량 강화 }\end{array}$ & 연수사업 & 4.86 & 1.62 & 계속 & $2016-2018$ & 양자무상 & 16 \\
\hline 486 & 글로벌연수(ODA) & $\begin{array}{l}\text { 청소년정책 및 활동 } \\
\text { 프로그램 개발·운영 } \\
\text { 역량강화 }\end{array}$ & 연수사업 & 4.86 & 1.62 & 계속 & $2016-2018$ & 양자무상 & 4 \\
\hline 487 & 글로벌연수(ODA) & $\begin{array}{l}\text { 아시아 개도국 식품위 } \\
\text { 생 공무원 역량 강화 }\end{array}$ & 연수사업 & 4.86 & 1.62 & 계속 & $2016-2018$ & 양자무상 & 12 \\
\hline 488 & 글로벌연수(ODA) & 글로벌 공공 HRD & 연수사업 & 4.86 & 1.62 & 계속 & $2016-2018$ & 양자무상 & 17 \\
\hline 489 & 글로벌연수(ODA) & $\begin{array}{l}\text { (대구) 섬유산업 발전 } \\
\text { 전략 }\end{array}$ & 연수사업 & 4.86 & 1.62 & 계속 & $2016-2018$ & 양자무상 & 8 \\
\hline 490 & 글로벌연수(ODA) & 인권정책발전 & 연수사업 & 4.86 & 1.62 & 계속 & $2016-2018$ & 양자무상 & 10 \\
\hline 491 & 글로벌연수(ODA) & $\begin{array}{l}\text { 마약범죄 퇴치 및 수 } \\
\text { 사 }\end{array}$ & 연수사업 & 4.86 & 1.62 & 계속 & $2016-2018$ & 양자무상 & 16 \\
\hline 492 & 글로벌연수(ODA) & $\begin{array}{l}\text { 석유품질관리시스템 } \\
\text { 실무교육 }\end{array}$ & 연수사업 & 4.86 & 1.62 & 계속 & $2016-2018$ & 양자무상 & 7 \\
\hline 493 & 글로벌연수(ODA) & $\begin{array}{l}\text { 사이버범죄 대응역량 } \\
\text { 강화 }\end{array}$ & 연수사업 & 4.86 & 1.62 & 계속 & $2016-2018$ & 양자무상 & 16 \\
\hline 494 & 글로벌연수(ODA) & \begin{tabular}{|l|} 
기상위성자료 활용 능 \\
력 향상
\end{tabular} & 연수사업 & 4.86 & 1.62 & 계속 & $2016-2018$ & 양자무상 & 13 \\
\hline 495 & 글로벌연수(ODA) & $\begin{array}{l}\text { 선거법제 개선 지원 } \\
\text { 세미나 }\end{array}$ & 연수사업 & 4.86 & 1.62 & 계속 & $2016-2018$ & 양자무상 & 16 \\
\hline 496 & 글로벌연수(ODA) & $\begin{array}{l}\text { 소비자업무 선진화 및 } \\
\text { 전문가 양성 }\end{array}$ & 연수사업 & 4.86 & 1.62 & 계속 & $2017-2019$ & 양자무상 & 12 \\
\hline 497 & 글로벌연수(ODA) & $\begin{array}{l}\text { 직업교육훈련 및 자격 } \\
\text { 제도 전문가 양성(아 } \\
\text { 프리카) }\end{array}$ & 연수사업 & 4.86 & 1.62 & 계속 & $2017-2019$ & 양자무상 & 9 \\
\hline 498 & 글로벌연수(ODA) & $\begin{array}{l}\text { 국가 측량 및 공간정 } \\
\text { 보기관 역량강화 }\end{array}$ & 연수사업 & 4.86 & 1.62 & 계속 & $2017-2019$ & 양자무상 & 9 \\
\hline 499 & 글로벌연수(ODA) & $\begin{array}{l}\text { 출입국 관리행정 역량 } \\
\text { 강화 }\end{array}$ & 연수사업 & 4.86 & 1.62 & 계속 & $2017-2019$ & 양자무상 & 16 \\
\hline 500 & 글로벌연수(ODA) & 글로벌행정혁신 & 연수사업 & 4.86 & 1.62 & 계속 & $2017-2019$ & 양자무상 & 17 \\
\hline 501 & 글로벌연수(ODA) & $\begin{array}{l}\text { 공공조달 공무원 역량 } \\
\text { 강화(아프리카) }\end{array}$ & 연수사업 & 4.86 & 1.62 & 계속 & $2017-2019$ & 양자무상 & 16 \\
\hline 502 & 글로벌연수(ODA) & $\begin{array}{l}\text { 중소기업 정책 역량강 } \\
\text { 화(중동CIS) }\end{array}$ & 연수사업 & 4.86 & 1.62 & 계속 & $2017-2019$ & 양자무상 & 8 \\
\hline 503 & 글로벌연수(ODA) & $\begin{array}{l}\begin{array}{l}\text { 지방행정 역량강화(아 } \\
\text { 프리카) }\end{array} \\
\end{array}$ & 연수사업 & 4.86 & 1.62 & 계속 & $2017-2019$ & 양자무상 & 17 \\
\hline 504 & 글로벌연수(ODA) & 범죄예방 전략수립 & 연수사업 & 2.03 & 2.03 & 신규 & 2018 & 양자무상 & 16 \\
\hline 505 & 글로벌연수(ODA) & 교육행정 역량강화 & 연수사업 & 6.08 & 2.03 & 신규 & $2018-2020$ & 양자무상 & 4 \\
\hline 506 & 글로벌연수(ODA) & $\begin{array}{l}\text { 국가 교육과정 및 교 } \\
\text { 과서 개발 체제 지원 }\end{array}$ & 연수사업 & 6.08 & 2.03 & 신규 & $2018-2020$ & 양자무상 & 4 \\
\hline 507 & 글로벌연수(ODA) & 과학기술 전략 개발 & 연수사업 & 2.03 & 2.03 & 신규 & 2018 & 양자무상 & 9 \\
\hline 508 & 글로벌연수(ODA) & $\begin{array}{l}\text { 자연재해 조기경보시 } \\
\text { 스템 }\end{array}$ & 연수사업 & 6.08 & 2.03 & 신규 & $2018-2020$ & 양자무상 & 11 \\
\hline 509 & 글로벌연수(ODA) & $\begin{array}{l}\text { 부동산 과세기준 가격 } \\
\text { 조사 역량강화 }\end{array}$ & 연수사업 & 6.08 & 2.03 & 신규 & $2018-2020$ & 양자무상 & 11 \\
\hline
\end{tabular}




\begin{tabular}{|c|c|c|c|c|c|c|c|c|c|}
\hline & 세부사업명 & 내역사업명 & 사업 유형 & $\begin{array}{c}\text { 총사업예산 } \\
\text { (억원) }\end{array}$ & $\begin{array}{l}\text { ‘18년예 } \\
\text { 산 (억원) }\end{array}$ & $\begin{array}{l}\text { 신규/ } \\
\text { 계속 }\end{array}$ & $\begin{array}{l}\text { 총사업 } \\
\text { 기간 }\end{array}$ & $\begin{array}{c}\text { 구분 } \\
\text { (양-다자 } \\
\text { ) }\end{array}$ & $\begin{array}{l}\text { SDGs } \\
\text { 목표 }\end{array}$ \\
\hline 510 & 글로벌연수(ODA) & $\begin{array}{l}\text { 교통혼잡 완화를 위한 } \\
\text { 교통관리 및 지능형 } \\
\text { 교통 시스템 전문가 } \\
\text { 양성 }\end{array}$ & 연수사업 & 2.03 & 2.03 & 신규 & 2018 & 양자무상 & 9 \\
\hline 511 & 글로벌연수(ODA) & $\begin{array}{l}\text { 중소기업금융 역량강 } \\
\text { 화 }\end{array}$ & 연수사업 & 6.08 & 2.03 & 신규 & $2018-2020$ & 양자무상 & 8 \\
\hline 512 & 글로벌연수(ODA) & $\begin{array}{l}\text { 국유부동산의 효율적 } \\
\text { 관리·처분 및 개발 } \\
\text { 역량강화 }\end{array}$ & 연수사업 & 2.03 & 2.03 & 신규 & 2018 & 양자무상 & 11 \\
\hline 513 & 글로벌연수(ODA) & $\begin{array}{l}\text { ICT를 이용한 기상업 } \\
\text { 무향상 }\end{array}$ & 연수사업 & 6.08 & 2.03 & 신규 & $2018-2020$ & 양자무상 & 16 \\
\hline 514 & 글로벌연수(ODA) & \begin{tabular}{|l|} 
저탄소 대중교통 정책 \\
및 운영기술
\end{tabular} & 연수사업 & 2.03 & 2.03 & 신규 & 2018 & 양자무상 & 13 \\
\hline 515 & 글로벌연수(ODA) & $\begin{array}{l}\text { 안정적인 e-gov 이행 } \\
\text { 을 위한 사이버보안 } \\
\text { 역량강화 }\end{array}$ & 연수사업 & 2.03 & 2.03 & 신규 & 2018 & 양자무상 & 16 \\
\hline 516 & 글로벌연수(ODA) & 범죄방지 및 형사사법 & 연수사업 & 2.03 & 2.03 & 신규 & 2018 & 양자무상 & 16 \\
\hline 517 & 글로벌연수(ODA) & $\begin{array}{l}\text { 지속가능한 발전을 위 } \\
\text { 한 친환경 광해관리 } \\
\text { 역량강화(심화) }\end{array}$ & 연수사업 & 6.08 & 2.03 & 신규 & $2018-2020$ & 양자무상 & 12 \\
\hline 518 & 글로벌연수(ODA) & 글로벌 공공 HRD & 연수사업 & 6.08 & 2.03 & 신규 & $2018-2020$ & 양자무상 & 16 \\
\hline 519 & 글로벌연수(ODA) & $\begin{array}{l}\text { 지방정부 일자리창출 } \\
\text { 정책 역량강화 }\end{array}$ & 연수사업 & 6.08 & 2.03 & 신규 & $2018-2020$ & 양자무상 & 8 \\
\hline 520 & 글로벌연수(ODA) & $\begin{array}{l}\text { 수산동물 질병관리 및 } \\
\text { 생산단계 수산물 안전 } \\
\text { 관리 }\end{array}$ & 연수사업 & 6.08 & 2.03 & 신규 & $2018-2020$ & 양자무상 & 14 \\
\hline 521 & 글로벌연수(ODA) & $\begin{array}{l}\text { 해운항만물류 역량강 } \\
\text { 화 } \\
\end{array}$ & 연수사업 & 2.03 & 2.03 & 신규 & 2018 & 양자무상 & 16 \\
\hline 522 & 글로벌연수(ODA) & $\begin{array}{l}\text { 금융협동조합 운영 역 } \\
\text { 량강화 }\end{array}$ & 연수사업 & 6.08 & 2.03 & 신규 & $2018-2020$ & 양자무상 & 2 \\
\hline 523 & 글로벌연수(ODA) & $\begin{array}{l}\text { 기후변화대응을위한지 } \\
\text { 속가능한물관리 }\end{array}$ & 연수사업 & 6.08 & 2.03 & 신규 & $2018-2020$ & 양자무상 & 6 \\
\hline 524 & 글로벌연수(ODA) & $\begin{array}{l}\text { 국제 기록문화유산 관 } \\
\text { 리 역량강화(아시아) }\end{array}$ & 연수사업 & 4.86 & 1.62 & 계속 & $2017-2019$ & 양자무상 & 16 \\
\hline 525 & 글로벌연수(ODA) & $\begin{array}{l}\text { UNESCO 공동연수 - } \\
\text { 아시아, 아프리카 초 } \\
\text { 등교사 역량강화 }\end{array}$ & 연수사업 & 10.13 & 2.03 & 계속 & $2016-2020$ & 양자무상 & 4 \\
\hline 526 & 글로벌연수(ODA) & $\begin{array}{l}\text { AARDO 지속가능한 } \\
\text { 농업개발 }\end{array}$ & 연수사업 & 4.86 & 1.62 & 계속 & $2016-2018$ & 양자무상 & 2 \\
\hline 527 & 글로벌연수(ODA) & $\begin{array}{l}\text { SICA 특별연수 (1) 양 } \\
\text { 성평등정책 }\end{array}$ & 연수사업 & 6.32 & 2.11 & 계속 & $2016-2018$ & 양자무상 & 5 \\
\hline 528 & 글로벌연수(ODA) & $\begin{array}{l}\text { SICA 특별연수 (2) 자 } \\
\text { 연재해예방 및 위기관 } \\
\text { 리 }\end{array}$ & 연수사업 & 6.32 & 2.11 & 계속 & $2016-2018$ & 양자무상 & 13 \\
\hline 529 & 글로벌연수(ODA) & $\begin{array}{l}\text { Colombo Plan 공동연 } \\
\text { 수 - 기후변화대응을 } \\
\text { 위한 신재생에너지 및 } \\
\text { 폐기물 에너지화 }\end{array}$ & 연수사업 & 4.86 & 1.62 & 계속 & $2016-2018$ & 양자무상 & 13 \\
\hline 530 & 글로벌연수(ODA) & $\begin{array}{l}\text { ICAO 공동연수 - 공 } \\
\text { 항건설 및 운영과정 } \\
\end{array}$ & 연수사업 & 4.86 & 1.62 & 계속 & $2017-2019$ & 양자무상 & 9 \\
\hline 531 & 글로벌연수(ODA) & $\begin{array}{l}\mathrm{ICAO} \text { 공동연수 - 레 } \\
\text { 이더접근관제 }(\mathrm{RAC})\end{array}$ & 연수사업 & 4.86 & 1.62 & 계속 & $2017-2019$ & 양자무상 & 9 \\
\hline 532 & 글로벌연수(ODA) & $\begin{array}{l}\text { ICAO 공동연수 - 공 } \\
\text { 항포장평가(인증) }\end{array}$ & 연수사업 & 4.86 & 1.62 & 계속 & $2017-2019$ & 양자무상 & 9 \\
\hline 533 & 글로벌연수(ODA) & $\begin{array}{l}\text { ICAO 공동연수 - 항 } \\
\text { 공보안 및 안전(인증) }\end{array}$ & 연수사업 & 4.86 & 1.62 & 계속 & $2017-2019$ & 양자무상 & 9 \\
\hline 534 & 글로벌연수(ODA) & $\begin{array}{l}\text { 한-태 공동연수 (1) - } \\
\text { 농촌 개발 }\end{array}$ & 연수사업 & 6.08 & 2.03 & 계속 & $2017-2019$ & 양자무상 & 2 \\
\hline 535 & 글로벌연수(ODA) & $\begin{array}{l}\text { 한-태공동연수(2)-수 } \\
\text { 자원 관리 }\end{array}$ & 연수사업 & 6.08 & 2.03 & 계속 & $2017-2019$ & 양자무상 & 6 \\
\hline
\end{tabular}




\begin{tabular}{|c|c|c|c|c|c|c|c|c|c|}
\hline & 세부사업명 & 내역사업명 & 사업 유형 & $\begin{array}{c}\text { 총사업예산 } \\
\text { (억원) }\end{array}$ & $\begin{array}{l}\text { '18년예 } \\
\text { 산 (억원) }\end{array}$ & $\begin{array}{l}\text { 신규/ } \\
\text { 계속 }\end{array}$ & $\begin{array}{l}\text { 총사업 } \\
\text { 기간 }\end{array}$ & $\begin{array}{c}\text { 구분 } \\
\text { (양-다자 } \\
\text { ) }\end{array}$ & $\begin{array}{l}\text { SDGs } \\
\text { 목표 }\end{array}$ \\
\hline 536 & 글로벌연수(ODA) & $\begin{array}{l}\text { IAEA 공동연수 - 원 } \\
\text { 전기획 및 사업관리 }\end{array}$ & 연수사업 & 1.46 & 1.46 & 신규 & 2018 & 양자무상 & 7 \\
\hline 537 & 글로벌연수(ODA) & $\begin{array}{l}\text { SAARC 특별연수 (1) } \\
\text { 신재생에너지관리 }\end{array}$ & 연수사업 & 1.30 & 1.30 & 신규 & 2018 & 양자무상 & 9 \\
\hline 538 & 글로벌연수(ODA) & $\begin{array}{l}\text { SAARC 특별연수 (2) } \\
\text { 보건의료정책관리 }\end{array}$ & 연수사업 & 1.30 & 1.30 & 신규 & 2018 & 양자무상 & 3 \\
\hline 539 & 글로벌연수(ODA) & $\begin{array}{l}\text { UNISDR 연수 - 도시 } \\
\text { 방재역량강화 }\end{array}$ & 연수사업 & 1.46 & 1.46 & 신규 & 2018 & 양자무상 & 16 \\
\hline 540 & 글로벌연수(ODA) & $\begin{array}{l}\text { UNESCAP 지속가능한 } \\
\text { 개발과 재난위기관리 } \\
\text { 를 위한 지리정보시스 } \\
\text { 템 역량개발 }\end{array}$ & 연수사업 & 1.46 & 1.46 & 신규 & 2018 & 양자무상 & 16 \\
\hline 541 & 글로벌연수(ODA) & $\begin{array}{l}\text { 한-싱 공동연수 - 고 } \\
\text { 위정책자 관리 }\end{array}$ & 연수사업 & 1.46 & 1.46 & 신규 & 2018 & 양자무상 & 16 \\
\hline 542 & 글로벌연수(ODA) & $\begin{array}{l}\text { 한-싱 공동연수 }- \text { 수 } \\
\text { 자원 개발 및 관리 }\end{array}$ & 연수사업 & 1.46 & 1.46 & 신규 & 2018 & 양자무상 & 6 \\
\hline 543 & 글로벌연수(ODA) & $\mathrm{AU}$ 공동연수 & 연수사업 & 1.62 & 1.62 & 신규 & 2018 & 양자무상 & 16 \\
\hline 544 & 글로벌연수(ODA) & $\begin{array}{l}\text { CARICOM 특별연수 - } \\
\text { 전자정부 }\end{array}$ & 연수사업 & 1.62 & 1.62 & 신규 & 2018 & 양자무상 & 16 \\
\hline 545 & 글로벌연수(ODA) & $\begin{array}{l}\text { 차세 대한국어인재양성 } \\
\text { (학생초 중급) }\end{array}$ & 연수사업 & 4.86 & 1.62 & 계속 & $2016-2018$ & 양자무상 & 4 \\
\hline 546 & 글로벌연수(ODA) & $\begin{array}{l}\text { 한국어교사양성및능력 } \\
\text { 배양(고급) }\end{array}$ & 연수사업 & 4.86 & 1.62 & 계속 & $2016-2018$ & 양자무상 & 4 \\
\hline 547 & 글로벌연수(ODA) & $\begin{array}{l}\text { 한국어문화전문가양성 } \\
\text { (중급) }\end{array}$ & 연수사업 & 4.86 & 1.62 & 계속 & $2016-2018$ & 양자무상 & 4 \\
\hline 548 & 글로벌연수(ODA) & $\begin{array}{l}\text { 한국어와 한국 문화의 } \\
\text { 이해 (공무원 초급) }\end{array}$ & 연수사업 & 4.86 & 1.62 & 계속 & $2016-2018$ & 양자무상 & 4 \\
\hline 549 & 글로벌연수(ODA) & $\begin{array}{l}\text { SLA 구상 이행을 위 } \\
\text { 한 감영병 관리 전문 } \\
\text { 인력 양성(1) }\end{array}$ & 연수사업 & 9.72 & 3.24 & 계속 & $2016-2018$ & 양자무상 & 3 \\
\hline 550 & 글로벌연수(ODA) & $\begin{array}{l}\text { PIC 특별연수 (1) - } \\
\text { 기후변화대응 }\end{array}$ & 연수사업 & 1.22 & 1.22 & 신규 & 2018 & 양자무상 & 13 \\
\hline 551 & 글로벌연수(ODA) & $\begin{array}{l}\text { PIC 특별연수 (2) - } \\
\text { 수자원개발 및 관리 }\end{array}$ & 연수사업 & 1.22 & 1.22 & 신규 & 2018 & 양자무상 & 6 \\
\hline 552 & 글로벌연수(ODA) & $\begin{array}{l}\text { ASEAN 특별연수 (1) } \\
- \text { 차세대 방송컨텐츠 } \\
\text { 제작 교류 워크숍 }\end{array}$ & 연수사업 & 1.46 & 1.46 & 신규 & 2018 & 양자무상 & 9 \\
\hline 553 & 글로벌연수(ODA) & $\begin{array}{l}\text { ASEAN 특별연수 (2) } \\
\text { - 포괄적 환경 모니터 } \\
\text { 링 }\end{array}$ & 연수사업 & 1.46 & 1.46 & 신규 & 2018 & 양자무상 & 6 \\
\hline 554 & 글로벌연수(ODA) & 외교관 역량강화 & 연수사업 & 6.08 & 2.03 & 신규 & $2018-2020$ & 양자무상 & 17 \\
\hline 555 & 글로벌연수(ODA) & $\begin{array}{l}\text { 석사학위-대기과학 역 } \\
\text { 량강화 }\end{array}$ & 장학지원 & 20.25 & 7.13 & 계속 & $2016-2020$ & 양자무상 & 13 \\
\hline 556 & 글로벌연수(ODA) & $\begin{array}{l}\text { 석사학위-아세안과학 } \\
\text { 기술융합 }\end{array}$ & 장학지원 & 27.00 & 9.51 & 계속 & $2016-2020$ & 양자무상 & 17 \\
\hline 557 & 글로벌연수(ODA) & $\begin{array}{l}\text { 석사학위-공공관리 및 } \\
\text { 행정개혁 역량강화 }\end{array}$ & 장학지원 & 27.00 & 7.61 & 계속 & $2017-2021$ & 양자무상 & 16 \\
\hline 558 & 글로벌연수(ODA) & $\begin{array}{l}\text { 석사학위-지방행정 역 } \\
\text { 량강화 }\end{array}$ & 장학지원 & 27.00 & 7.61 & 계속 & $2017-2021$ & 양자무상 & 16 \\
\hline 559 & 글로벌연수(ODA) & $\begin{array}{l}\text { 석사학위-산업 및 무 } \\
\text { 역정책 역량강화 }\end{array}$ & 장학지원 & 27.00 & 7.61 & 계속 & $2017-2021$ & 양자무상 & 8 \\
\hline 560 & 글로벌연수(ODA) & $\begin{array}{l}\text { 석사학위-재정 및 조 } \\
\text { 세정책 역량강화 }\end{array}$ & 장학지원 & 27.00 & 7.61 & 계속 & $2017-2021$ & 양자무상 & 6 \\
\hline 561 & 글로벌연수(ODA) & $\begin{array}{l}\text { 석사학위-아프리카 국 } \\
\text { 가개발정책 역량강화 }\end{array}$ & 장학지원 & 27.00 & 7.61 & 계속 & $2017-2021$ & 양자무상 & 8 \\
\hline 562 & 글로벌연수(ODA) & $\begin{array}{l}\text { 석사학위-도시개발정 } \\
\text { 책 역량강화 }\end{array}$ & 장학지원 & 27.00 & 7.61 & 계속 & $2017-2021$ & 양자무상 & 1 \\
\hline 563 & 글로벌연수(ODA) & $\begin{array}{l}\text { 석사학위-농업경제 역 } \\
\text { 량강화 }\end{array}$ & 장학지원 & 27.00 & 7.61 & 계속 & $2017-2021$ & 양자무상 & 2 \\
\hline 564 & 글로벌연수(ODA) & $\begin{array}{l}\text { 석사학위-농업공학 역 } \\
\text { 량강화 }\end{array}$ & 장학지원 & 27.00 & 7.61 & 계속 & $2017-2021$ & 양자무상 & 2 \\
\hline
\end{tabular}




\begin{tabular}{|c|c|c|c|c|c|c|c|c|c|}
\hline & 세부사업명 & 내역사업명 & 사업 유형 & $\begin{array}{c}\text { 총사업예산 } \\
\text { (억원) }\end{array}$ & $\begin{array}{l}\text { '18년 예 } \\
\text { 산 (억원) }\end{array}$ & $\begin{array}{l}\text { 신규/ } \\
\text { 계속 }\end{array}$ & $\begin{array}{l}\text { 총사업 } \\
\text { 기간 }\end{array}$ & $\begin{array}{c}\text { 구분 } \\
\text { (양-다자 } \\
\text { ) }\end{array}$ & $\begin{array}{l}\mathrm{SDGS} \\
\text { 목표 }\end{array}$ \\
\hline 565 & 글로벌연수(ODA) & $\begin{array}{l}\text { 석사학위-농업생산성 } \\
\text { 역량강화 }\end{array}$ & 장학지원 & 27.00 & 7.61 & 계속 & $2017-2021$ & 양자무상 & 2 \\
\hline 566 & 글로벌연수(ODA) & $\begin{array}{l}\text { 석사학위-지역개발 역 } \\
\text { 량강화 }\end{array}$ & 장학지원 & 48.60 & 13.69 & 계속 & $2017-2021$ & 양자무상 & 2 \\
\hline 567 & 글로벌연수(ODA) & $\begin{array}{l}\text { 석사학위-수산발전 역 } \\
\text { 량강화 }\end{array}$ & 장학지원 & 27.00 & 7.61 & 계속 & $2017-2021$ & 양자무상 & 14 \\
\hline 568 & 글로벌연수(ODA) & $\begin{array}{l}\text { 석사학위-수자원관리 } \\
\text { 역량강화 }\end{array}$ & 장학지원 & 27.00 & 7.61 & 계속 & $2017-2021$ & 양자무상 & 6 \\
\hline 569 & 글로벌연수(ODA) & $\begin{array}{l}\text { 석사학위-에너지정책 } \\
\text { 역량강화 }\end{array}$ & 장학지원 & 27.00 & 7.61 & 계속 & $2017-2021$ & 양자무상 & 7 \\
\hline 570 & 글로벌연수(ODA) & \begin{tabular}{|l} 
석사학위-정보통신정 \\
책 역량강화
\end{tabular} & 장학지원 & 27.00 & 7.61 & 계속 & $2017-2021$ & 양자무상 & 9 \\
\hline 571 & 글로벌연수(ODA) & $\begin{array}{l}\text { 석사학위-글로벌 보건 } \\
\text { 안보 역량강화 }\end{array}$ & 장학지원 & 27.00 & 7.61 & 계속 & $2017-2021$ & 양자무상 & 3 \\
\hline 572 & 글로벌연수(ODA) & $\begin{array}{l}\text { 석사학위-양성평등 역 } \\
\text { 량강화 }\end{array}$ & 장학지원 & 27.00 & 7.61 & 계속 & $2017-2021$ & 양자무상 & 10 \\
\hline 573 & 글로벌연수(ODA) & $\begin{array}{l}\text { 석사학위-금융핵심인 } \\
\text { 력양성 }\end{array}$ & 장학지원 & 27.00 & 0.90 & 계속 & $2015-2019$ & 양자무상 & 16 \\
\hline 574 & 글로벌연수(ODA) & $\begin{array}{l}\text { 석사학위- 경제정책역 } \\
\text { 량강화(1) }\end{array}$ & 장학지원 & 27.00 & 0.90 & 계속 & $2014-2018$ & 양자무상 & 8 \\
\hline 575 & 글로벌연수(ODA) & $\begin{array}{l}\text { 석사학위- 농축산 가 } \\
\text { 공/마케팅 }\end{array}$ & 장학지원 & 27.00 & 0.95 & 계속 & $2015-2019$ & 양자무상 & 2 \\
\hline 576 & 글로벌연수(ODA) & \begin{tabular}{|l} 
석사학위- 식량안보 \\
및 농업기술역량강화
\end{tabular} & 장학지원 & 27.00 & 0.95 & 계속 & $2014-2018$ & 양자무상 & 2 \\
\hline 577 & 글로벌연수(ODA) & $\begin{array}{l}\text { 석사학위- 한국개발경 } \\
\text { 험 및 경제협력 }\end{array}$ & 장학지원 & 27.00 & 0.95 & 계속 & $2014-2018$ & 양자무상 & 8 \\
\hline 578 & 글로벌연수(ODA) & $\begin{array}{l}\text { 석사학위- 경제정책역 } \\
\text { 량강화(2) } \\
\end{array}$ & 장학지원 & 27.00 & 0.90 & 계속 & $2014-2018$ & 양자무상 & 8 \\
\hline 579 & 글로벌연수(ODA) & $\begin{array}{l}\text { 석사학위- 공공행정역 } \\
\text { 량강화(1) }\end{array}$ & 장학지원 & 27.00 & 0.95 & 계속 & $2014-2018$ & 양자무상 & 16 \\
\hline 580 & 글로벌연수(ODA) & $\begin{array}{l}\text { 석사학위- 국토개발정 } \\
\text { 책역량강화 }\end{array}$ & 장학지원 & 27.00 & 0.95 & 계속 & $2014-2018$ & 양자무상 & 11 \\
\hline 581 & 글로벌연수(ODA) & $\begin{array}{l}\text { 석사학위-글로벌ICT } \\
\text { 융합 } \\
\end{array}$ & 장학지원 & 27.00 & 0.95 & 계속 & $2014-2018$ & 양자무상 & 9 \\
\hline 582 & 글로벌연수(ODA) & \begin{tabular}{|l|} 
석사학위- 경제 및 산 \\
업정책
\end{tabular} & 장학지원 & 27.00 & 0.95 & 계속 & $2014-2018$ & 양자무상 & 8 \\
\hline 583 & 글로벌연수(ODA) & \begin{tabular}{|l|} 
석사학위- 지역공동체 \\
개발 개도국 지도자 \\
및 교수요원 양성과정 \\
(2)
\end{tabular} & 장학지원 & 27.00 & 0.81 & 계속 & $2014-2018$ & 양자무상 & 2 \\
\hline 584 & 글로벌연수(ODA) & $\begin{array}{l}\text { 석사학위-지역공동체 } \\
\text { 개발 개도국 지도자 } \\
\text { 및 교수요원 양성과정 } \\
\text { (1) }\end{array}$ & 장학지원 & 48.60 & 1.33 & 계속 & $2014-2018$ & 양자무상 & 2 \\
\hline 585 & 글로벌연수(ODA) & $\begin{array}{l}\text { 석사학위- 여성지도자 } \\
\text { 역량강화 }\end{array}$ & 장학지원 & 27.00 & 0.95 & 계속 & $2014-2018$ & 양자무상 & 10 \\
\hline 586 & 글로벌연수(ODA) & \begin{tabular}{|l|} 
석사학위- 지역공동체 \\
개발 개도국 지도자 \\
및 교수요원 양성과정 \\
(3)
\end{tabular} & 장학지원 & 27.00 & 0.81 & 계속 & $2014-2018$ & 양자무상 & 2 \\
\hline 587 & 글로벌연수(ODA) & \begin{tabular}{|l|} 
석사학위- 전기전자공 \\
학
\end{tabular} & 장학지원 & 27.00 & 0.86 & 계속 & $2015-2019$ & 양자무상 & 9 \\
\hline 588 & 글로벌연수(ODA) & $\begin{array}{l}\text { 석사학위-국가보건정 } \\
\text { 책 }\end{array}$ & 장학지원 & 27.00 & 0.90 & 계속 & $2014-2018$ & 양자무상 & 3 \\
\hline 589 & 글로벌연수(ODA) & $\begin{array}{l}\text { 석사학위-금융정책 역 } \\
\text { 량강화 } \\
\end{array}$ & 장학지원 & 27.00 & 7.61 & 신규 & $2018-2022$ & 양자무상 & 8 \\
\hline 590 & 글로벌연수(ODA) & 석사학위-전자전기 & 장학지원 & 27.00 & 7.61 & 신규 & $2018-2022$ & 양자무상 & 9 \\
\hline 591 & 글로벌연수(ODA) & $\begin{array}{l}\text { 석사학위- 교육정책역 } \\
\text { 량강화 }\end{array}$ & 장학지원 & 27.00 & 7.61 & 신규 & $2018-2022$ & 양자무상 & 16 \\
\hline 592 & 글로벌연수(ODA) & 수시발굴및융합사업비 & 연수사업 & & 3.00 & 계속 & 2018 & 양자무상 & \\
\hline 593 & 글로벌연수(ODA) & 연수지원경비 & 기타 & & 29.43 & 계속 & 2018 & 양자무상 & \\
\hline
\end{tabular}




\begin{tabular}{|c|c|c|c|c|c|c|c|c|c|}
\hline & 세부사업명 & 내역사업명 & 사업 유형 & $\begin{array}{c}\text { 총사업예산 } \\
\text { (억원) }\end{array}$ & $\begin{array}{l}\text { ‘18년예 } \\
\text { 산 (억원) }\end{array}$ & $\begin{array}{l}\text { 신규/ } \\
\text { 계속 }\end{array}$ & $\begin{array}{l}\text { 총사업 } \\
\text { 기간 }\end{array}$ & $\begin{array}{c}\text { 구분 } \\
\text { (양-다자 } \\
\text { ) }\end{array}$ & $\begin{array}{l}\mathrm{SDGS} \\
\text { 목표 }\end{array}$ \\
\hline 594 & 글로벌연수(ODA) & 사후관리비 & 기타 & & 5.16 & 계속 & 2018 & 양자무상 & \\
\hline 595 & 글로벌연수(ODA) & $\begin{array}{l}\text { 국제협력 연수센터 운 } \\
\text { 영비 }\end{array}$ & 기타 & & 43.66 & 계속 & 2018 & 양자무상 & \\
\hline 596 & 글로벌연수(ODA) & 사업행정비 & 행정비용 & & 9.77 & 계속 & 2018 & 양자무상 & \\
\hline 597 & 국제기구협력(ODA) & $\begin{array}{l}\text { 한-WFP 새마을 제로 } \\
\text { 헝거 커뮤니티 사업 }\end{array}$ & 프로젝트 & 310.50 & - & 계속 & $2011-2018$ & 다자성양자 & 2 \\
\hline 598 & 국제기구협력(ODA) & $\begin{array}{l}\text { UNICEF 아동의 안전 } \\
\text { 하고 올바른 생존지원 } \\
\text { 프로그램 }\end{array}$ & 프로젝트 & 429.40 & - & 계속 & $2013-2018$ & 다자성양자 & 3 \\
\hline 599 & 국제기구협력(ODA) & $\begin{array}{l}\text { 교육을 위한 글로벌 } \\
\text { 파트너십(GPE) 신탁 } \\
\text { 기금 }\end{array}$ & 프로그램 & 56.00 & 8.05 & 계속 & $2014-2020$ & 다자성양자 & 4 \\
\hline 600 & 국제기구협력(ODA) & $\begin{array}{l}\text { 한-WFP 식량안보 프 } \\
\text { 로그램 }\end{array}$ & 프로젝트 & 206.00 & 57.50 & 계속 & $2015-2019$ & 다자성양자 & 2 \\
\hline 601 & 국제기구협력(ODA) & $\begin{array}{l}\text { UNIDO 쿠바 산업역 } \\
\text { 량강화 프로그램 }\end{array}$ & 프로젝트 & 17.67 & 5.52 & 계속 & $2016-2018$ & 다자성양자 & 9 \\
\hline 602 & 국제기구협력(ODA) & $\begin{array}{l}\text { UNIDO 쿠바 음악산 } \\
\text { 업 경쟁력 강화사업 }\end{array}$ & 프로젝트 & 14.82 & 3.45 & 계속 & $2016-2018$ & 다자성양자 & 9 \\
\hline 603 & 국제기구협력(ODA) & $\begin{array}{l}\text { UNHCR 카메룬 동부 } \\
\text { 지역 난민 공동체 개 } \\
\text { 발사업 }\end{array}$ & 프로젝트 & 62.70 & 36.43 & 계속 & $2016-2018$ & 다자성양자 & 1 \\
\hline 604 & 국제기구협력(ODA) & $\begin{array}{l}\mathrm{WHO} \text { 피지 학교보건 } \\
\text { 증진사업 }\end{array}$ & 프로젝트 & 34.20 & 11.50 & 계속 & $2016-2019$ & 다자성양자 & 3 \\
\hline 605 & 국제기구협력(ODA) & $\begin{array}{l}\text { UNHCR 난민 아동(여 } \\
\text { 아)의 양질의 교육에 } \\
\text { 대한 접근성 향상 사 } \\
\text { 업 }\end{array}$ & 프로젝트 & 57.50 & 19.20 & 계속 & $2017-2019$ & 다자성양자 & 4 \\
\hline 606 & 국제기구협력(ODA) & $\begin{array}{l}\text { UNICEF 교육 및 보건 } \\
\text { 개선을 통한 소녀들의 } \\
\text { 보다 나은 삶 지원 프 } \\
\text { 로그램 }\end{array}$ & 프로젝트 & 460.00 & 117.59 & 계속 & $2017-2021$ & 다자성양자 & 4 \\
\hline 607 & 국제기구협력(ODA) & $\begin{array}{l}\text { WHO 항생제 내성 } \\
\text { (AMR) 등 신규 감염 } \\
\text { 병 대응을 위한 국가 } \\
\text { 대응능력 향상 사업 }\end{array}$ & 프로젝트 & 172.50 & 39.68 & 계속 & $2017-2021$ & 다자성양자 & 3 \\
\hline 608 & 국제기구협력(ODA) & $\begin{array}{l}\text { UNESCO 남아시아 불 } \\
\text { 교 유적지에 대한 지 } \\
\text { 속가능 관광개발 지원 } \\
\text { 사업 }\end{array}$ & 프로젝트 & 5.18 & 1.73 & 계속 & $2017-2018$ & 다자성양자 & 11 \\
\hline 609 & 국제기구협력(ODA) & $\begin{array}{l}\text { UNESCO 인도네시아 } \\
\text { 및 나미비아 사이언스 } \\
\text { 파크 및 비즈니스 인 } \\
\text { 큐베이터 구축 지원사 } \\
\text { 업 }\end{array}$ & 프로젝트 & 4.03 & 3.45 & 계속 & $2017-2018$ & 다자성양자 & 9 \\
\hline 610 & 국제기구협력(ODA) & $\begin{array}{l}\text { WFP 니카라과 취약 } \\
\text { 지역 학교 급식을 통 } \\
\text { 한 기후변화 복원력 } \\
\text { 구축 지원사업 }\end{array}$ & 프로젝트 & 34.50 & 11.50 & 신규 & $2018-2021$ & 다자성양자 & 2 \\
\hline 611 & 국제기구협력(ODA) & $\begin{array}{l}\text { WFP 니제르 기후변 } \\
\text { 화 위험관리 역량강화 } \\
\text { 를 통한 식량안보 지 } \\
\text { 원사업 }\end{array}$ & 프로젝트 & 34.50 & 11.50 & 신규 & $2018-2022$ & 다자성양자 & 13 \\
\hline 612 & 국제기구협력(ODA) & $\begin{array}{l}\text { WFP 짐바브웨 기후 } \\
\text { 변화 위험관리 역량강 } \\
\text { 화를 통한 식량안보 } \\
\text { 지원사업 }\end{array}$ & 프로젝트 & 34.50 & 11.50 & 신규 & $2018-2021$ & 다자성양자 & 13 \\
\hline 613 & 국제기구협력(ODA) & $\begin{array}{l}\text { WFP 방글라데시 취 } \\
\text { 약계층 복원력 구축 } \\
\text { 및 지속가능 식량 시 } \\
\text { 스템 강화사업 }\end{array}$ & 프로젝트 & 52.90 & 14.38 & 신규 & $2018-2022$ & 다자성양자 & 2 \\
\hline
\end{tabular}




\begin{tabular}{|c|c|c|c|c|c|c|c|c|c|}
\hline & 세부사업명 & 내역사업명 & 사업 유형 & $\begin{array}{l}\text { 총사업예산 } \\
\text { (억원) }\end{array}$ & $\begin{array}{l}\text { ‘18년예 } \\
\text { 산 (억원) }\end{array}$ & $\begin{array}{l}\text { 신규/ } \\
\text { 계속 }\end{array}$ & $\begin{array}{l}\text { 총사업 } \\
\text { 기간 }\end{array}$ & $\begin{array}{c}\text { 구분 } \\
\text { (양-다자 } \\
\text { ) }\end{array}$ & $\begin{array}{l}\text { SDGs } \\
\text { 목표 }\end{array}$ \\
\hline 614 & 국제기구협력(ODA) & $\begin{array}{l}\text { UNDP 남수단 평화구 } \\
\text { 축 강화 및 공동체 통 } \\
\text { 합 지원사업 }\end{array}$ & 프로젝트 & 34.50 & 11.50 & 신규 & $2018-2021$ & 다자성양자 & 16 \\
\hline 615 & 국제기구협력(ODA) & $\begin{array}{l}\text { UNDP 사모아 여성의 } \\
\text { 정치활동 참여지원 사업 }\end{array}$ & 프로젝트 & 41.17 & 13.80 & 신규 & $2018-2021$ & 다자성양자 & 5 \\
\hline 616 & 국제기구협력(ODA) & $\begin{array}{l}\text { UNDP DR콩고 북키부 } \\
\text { 주 여성 및 청소년의 } \\
\text { 거버넌스 활동참여 지 } \\
\text { 원사업 }\end{array}$ & 프로젝트 & 34.50 & 11.50 & 신규 & $2018-2021$ & 다자성양자 & 16 \\
\hline 617 & 국제기구협력(ODA) & $\begin{array}{l}\text { WHO 전염병 대응 역 } \\
\text { 량강화를 위한 보건관 } \\
\text { 리 서비스 개선사업 }\end{array}$ & 프로젝트 & 67.16 & 17.25 & 신규 & $2018-2022$ & 다자성양자 & 3 \\
\hline 618 & 국제기구협력(ODA) & $\begin{array}{l}\text { UNHRC 남수단 평화 } \\
\text { 를 위한 소녀교육 사 } \\
\text { 업 }\end{array}$ & 프로젝트 & 57.50 & 29.56 & 신규 & & 다자성양자 & 4 \\
\hline 619 & 국제기구협력(ODA) & $\begin{array}{l}\text { UNMAS DR콩고 폭발 } \\
\text { 물 및 무기 제거를 통 } \\
\text { 한 평화 및 안정화 사 } \\
\text { 업 }\end{array}$ & 프로젝트 & 30.02 & 15.01 & 신규 & $2018-2019$ & 다자성양자 & 16 \\
\hline 620 & 국제기구협력(ODA) & 사업효과성제고비 & 기타 & & 3.75 & 계속 & 2018 & 다자성양자 & \\
\hline 621 & 국제기구협력(ODA) & 사업행정비 & 기타 & & 1.28 & 계속 & 2018 & 다자성양자 & \\
\hline 622 & $\begin{array}{l}\text { Development Action } \\
\text { Program(ODA) }\end{array}$ & $\begin{array}{l}\text { 창의적 가치창출 프로 } \\
\text { 그램 }\end{array}$ & 민관협력 & & 94.80 & 계속 & 2018 & 양자무상 & 17 \\
\hline 623 & $\begin{array}{l}\text { Development Action } \\
\text { Program(ODA) }\end{array}$ & $\begin{array}{l}\text { 개도국 주민 비즈니스 } \\
\text { 기회창출 프로그램 }\end{array}$ & 민관협력 & & 96.85 & 계속 & 2018 & 양자무상 & 8 \\
\hline 624 & $\begin{array}{l}\text { Development Action } \\
\text { Program(ODA) }\end{array}$ & $\begin{array}{l}\text { 기후변화대응 혁신 프 } \\
\text { 로그램 }\end{array}$ & 프로젝트 & & 5.20 & 계속 & 2018 & 양자무상 & 13 \\
\hline 625 & $\begin{array}{l}\text { Development Action } \\
\text { Program(ODA) }\end{array}$ & $\begin{array}{l}\text { 해외파트너십 프로그 } \\
\text { 램 }\end{array}$ & 민관협력 & & 79.18 & 계속 & 2018 & 양자무상 & 17 \\
\hline 626 & $\begin{array}{l}\text { Development Action } \\
\text { Program(ODA) }\end{array}$ & 사업행정비 & 행정비용 & & 2.87 & 계속 & 2018 & 양자무상 & \\
\hline 627 & 협력사업 지원(ODA) & 협력사업지원 & 기타 & & 580.90 & 계속 & 2018 & 양자무상 & 1 \\
\hline
\end{tabular}




\section{법무부 2018년도 ODA 예산 계획[안]}

\section{$\square$ 총괄}

(단위: 억원)

\begin{tabular}{l|c|c|c||c|c|c}
\hline \multirow{2}{*}{ ODA 시행부처(기관) } & \multicolumn{3}{|c||}{2017} & \multicolumn{3}{c}{2018 (요구) } \\
\cline { 2 - 7 } & 양자 무상 & 다자 & 합계 & 양자 무상 & 다자 & 합계 \\
\hline 법무부 & 8.47 & - & 8.47 & 10.78 & - & 10.78 \\
\hline
\end{tabular}

※ 다자성양자는 양자에 포함

○ '18년도 ODA 시행목표

- 개도국의 법제 개선 및 사회 안정 등을 통한 법치주의 확립 지원

0 주요 정책과제

- UNODC 파견을 통한 범죄 및 마약 이슈 대응 관련 국제적 협력 강화

- 라오스 마약퇴치역량 강화 및 콜롬비아 과학수사 지원을 통한 SDGs 달성에 기여

- 개발협력을 통한 인류정의 실현 및 개도국의 평화적인 사회 지향

\section{$\square$ 유형별 분류}

(억원, \%)

\begin{tabular}{|c|c|c|c|c|c|c|c|c|c|c|c|c|}
\hline \multirow[b]{2}{*}{ 구분 } & \multirow[b]{2}{*}{ 계 } & \multirow[b]{2}{*}{ 프로 } & \multirow[b]{2}{*}{$\begin{array}{l}\text { 프로 } \\
\text { 그램 }\end{array}$} & \multirow[b]{2}{*}{$\begin{array}{l}\text { 개발 } \\
\text { 컨설팅 }\end{array}$} & \multicolumn{4}{|c|}{ 기술협력 } & \multirow{2}{*}{$\begin{array}{c}\text { 민관 } \\
\text { 협력 } \\
\text { (NGO, } \\
\text { 기업) }\end{array}$} & \multirow[b]{2}{*}{$\begin{array}{l}\text { 행정 } \\
\text { 비용 }\end{array}$} & \multirow[b]{2}{*}{ 기타 } & \multirow[b]{2}{*}{$\begin{array}{l}\text { 순수 } \\
\text { 다자* }\end{array}$} \\
\hline & & & & & $\begin{array}{l}\text { 연수 } \\
\text { 사업 }\end{array}$ & $\begin{array}{l}\text { 장학 } \\
\text { 지원 }\end{array}$ & $\begin{array}{l}\text { 봉사단 } \\
\text { 파견 }\end{array}$ & $\begin{array}{l}\text { 기타 } \\
\text { 기술 } \\
\text { 협력 }\end{array}$ & & & & \\
\hline \multirow{2}{*}{ '17년 } & 8.47 & 3.40 & - & - & 1.40 & - & - & 1.62 & - & - & 2.09 & - \\
\hline & 100 & 40.1 & $\begin{array}{l}\cdots \\
-\end{array}$ & - & 16.1 & - & - & 19.1 & - & - & 24.7 & $\begin{array}{l}\cdots \\
-\end{array}$ \\
\hline '18년 & 10.78 & 6.98 & - & - & - & - & - & 1.7 & - & - & 2.1 & - \\
\hline (요구) & 100 & 64.7 & $\begin{array}{l}\cdots \\
-\end{array}$ & - & $\begin{array}{l}\cdots \\
-\end{array}$ & - & $\begin{array}{l}\cdots \\
-\end{array}$ & 15.8 & $\cdots$ & - & 19.5 & - \\
\hline
\end{tabular}

* 다자성양자를 제외한 순수다자만 해당되며, 다자성양자는 사업 유형에 맞게 분류

$\square$ 총 사업 목록

\begin{tabular}{|c|c|c|c|c|c|c|c|c|c|}
\hline & 세부사업명 & 내역사업명 & 사업 유형 & $\begin{array}{l}\text { 총사업 예산 } \\
\text { (억원) }\end{array}$ & $\begin{array}{l}\text { '18년예산 } \\
\text { (억원) }\end{array}$ & $\begin{array}{l}\text { 신규/ } \\
\text { 계속 }\end{array}$ & $\begin{array}{l}\text { 총사업 } \\
\text { 기간 }\end{array}$ & \begin{tabular}{|c|} 
구분 \\
(양·다자)
\end{tabular} & $\begin{array}{l}\text { SDGs } \\
\text { 목표 }\end{array}$ \\
\hline 1 & $\begin{array}{l}\text { 개발도상국 법제정비 } \\
\text { 지원 }\end{array}$ & $\begin{array}{l}\text { 개발도상국 법제정비 } \\
\text { 지원(라오스) }\end{array}$ & 기타기술협력 & 8.55 & 1.71 & 계속 & $2016-2020$ & 양자무상 & 16 \\
\hline 2 & $\begin{array}{l}\text { 국제형사협력지원 } \\
\text { (ODA) }\end{array}$ & $\begin{array}{l}\text { 유엔마약범죄사무소 } \\
\text { 파견 부담금 및 유엔 } \\
\text { 범죄예방.형사사법위 } \\
\text { 원회 부담금 }\end{array}$ & 기타 & & 2.09 & 계속 & $2017-2019$ & 다자성양자 & 16 \\
\hline 3 & 국제마약퇴치지원 & $\begin{array}{l}\text { 라오스 마약통제역량 } \\
\text { 강화 }\end{array}$ & 프로젝트 & 3.40 & 3.40 & 신규 & 1년 & 양자무상 & 16 \\
\hline 4 & $\begin{array}{l}\text { 콜롬비아 DNA 장비 } \\
\text { 및 연수 지원 }\end{array}$ & $\begin{array}{l}\text { 콜롬비아 과학수사분야 } \\
\text { 장비 및 연수 지원 }\end{array}$ & 프로젝트 & 3.58 & 3.58 & 신규 & 1년 & 양자무상 & 16 \\
\hline
\end{tabular}




\section{행정자치부 2018년도 ODA 예산 계획[안]}

$\square$ 총괄

(단위: 억원)

\begin{tabular}{l|c|c|c||c|c|c}
\hline \multirow{2}{*}{$\mathrm{ODA}$ 시행부처(기관) } & \multicolumn{3}{|c||}{2017} & \multicolumn{3}{c}{2018 (요구) } \\
\cline { 2 - 7 } & 양자 무상 & 다자 & 합계 & 양자 무상 & 다자 & 합계 \\
\hline 행정자치부 & 73.4 & - & 73.4 & 86.2 & - & 86.2 \\
\hline
\end{tabular}

※ 다자성양자는 양자에 포함

○ '18년도 ODA 시행목표

- 새마을 초청연수 50 여 개국 450 명 대상 실시, 새마을 시범마을 11 개국 41 개 마을 조성

- 우리나라의 전자정부 구축 및 추진 경험노하우 전수를 통해 개도국 전자정부 발전 지원과 국내기업의 해외진출 거점 확보

으주요 정책과제

- 새마을 초청연수를 통한 개도국 주민들의 자립역량 개발

- 새마을 시범마을 조성을 통한 개도국 농촌개발 및 자립기반 구축

- 전자정부 해외진출 전략국가를 중심으로 전자정부협력 센터를 운영하고 전자정부 협력 네트워크 구축을 강화하여, 국내기업의 해외진출 확대 추진

$\square$ 유형별 분류

(억원, \%)

\begin{tabular}{|c|c|c|c|c|c|c|c|c|c|c|c|c|}
\hline \multirow[b]{2}{*}{ 구분 } & \multirow[b]{2}{*}{ 계 } & \multirow[b]{2}{*}{ 프로 } & \multirow[b]{2}{*}{$\begin{array}{l}\text { 프로 } \\
\text { 그램 }\end{array}$} & \multirow[b]{2}{*}{$\begin{array}{l}\text { 개발 } \\
\text { 컨설팅 }\end{array}$} & \multicolumn{4}{|c|}{ 기술협력 } & \multirow{2}{*}{$\begin{array}{c}\text { 민관 } \\
\text { 협력 } \\
\text { (NGO, } \\
\text { 기업) }\end{array}$} & \multirow[b]{2}{*}{$\begin{array}{l}\text { 행정 } \\
\text { 비용 }\end{array}$} & \multirow[b]{2}{*}{ 기타 } & \multirow[b]{2}{*}{$\begin{array}{l}\text { 순수 } \\
\text { 다자* }\end{array}$} \\
\hline & & & & & $\begin{array}{l}\text { 연수 } \\
\text { 사업 }\end{array}$ & $\begin{array}{l}\text { 장학 } \\
\text { 지원 }\end{array}$ & $\begin{array}{l}\text { 봉사단 } \\
\text { 파견 }\end{array}$ & $\begin{array}{l}\text { 기타 } \\
\text { 기술 } \\
\text { 협력 }\end{array}$ & & & & \\
\hline \multirow{2}{*}{ '17년 } & 73.4 & 13.6 & 0.8 & 9.6 & 25.1 & - & - & 0.6 & $-\ldots$ & - & 23.8 & \\
\hline & 100 & 18.5 & 1.0 & 13.1 & 34.2 & - & - & 0.7 & - & - & 32.4 & - \\
\hline \multirow{2}{*}{$\begin{array}{l}\text { '18년 } \\
\text { (요구) }\end{array}$} & 86.2 & 13.7 & 3.0 & 14.9 & 27.0 & - & $\therefore$ & 1.5 & - & - & 26.2 & - \\
\hline & 100 & 15.9 & 3.5 & 17.3 & & - & $\cdots$ & 1.7 & - & - & 30.4 & \\
\hline
\end{tabular}

* 다자성양자를 제외한 순수다자만 해당되며, 다자성양자는 사업 유형에 맞게 분류

$\square$ 총 사업 목록

\begin{tabular}{l|l|l|l|r|r|r|r|r|r}
\hline \multicolumn{1}{|c|}{ 세부사업명 } & 내역사업명 & 사업 유형 & $\begin{array}{c}\text { 총사업예산 } \\
\text { (억원) }\end{array}$ & $\begin{array}{c}18 \text { 년예산 } \\
\text { (억원) }\end{array}$ & $\begin{array}{l}\text { 신규/ } \\
\text { 계속 }\end{array}$ & $\begin{array}{c}\text { 총사업 } \\
\text { 기간 }\end{array}$ & $\begin{array}{c}\text { 구분 } \\
\text { (양.다자) }\end{array}$ & $\begin{array}{c}\text { SDGs } \\
\text { 목표 }\end{array}$ \\
\hline 1 & $\begin{array}{l}\text { 맞춤형 새마을운동 } \\
\text { 지원사업 }\end{array}$ & 개도국 새마을 초청연수 & 연수사업 & 18.13 & 18.13 & 신규 & 2018 & 양자무상 & 1 \\
\hline 2 & $\begin{array}{l}\text { 맞춤형 새마을운동 } \\
\text { 지원사업 }\end{array}$ & $\begin{array}{l}\text { 라오스 새마을운동 시 } \\
\text { 범마을 조성 및 관리 }\end{array}$ & 프로젝트 & 11.02 & 1.74 & 계속 & $2015-2019$ & 양자무상 & 1 \\
\hline 3 & $\begin{array}{l}\text { 맞춤형 새마을운동 } \\
\text { 지원사업 }\end{array}$ & $\begin{array}{l}\text { 우간다 새마을운동 시 } \\
\text { 범마을 조성 및 관리 }\end{array}$ & 프로젝트 & 14.27 & 2.53 & 계속 & $2015-2019$ & 양자무상 & 1 \\
\hline 4 & $\begin{array}{l}\text { 맞춤형 새마을운동 } \\
\text { 지원사업 }\end{array}$ & $\begin{array}{l}\text { 동티모르 새마을운동 시 } \\
\text { 범마을 조성 및 관리 }\end{array}$ & 프로젝트 & 7.42 & 1.58 & 계속 & $2016-2020$ & 양자무상 & 1 \\
\hline 5 & $\begin{array}{l}\text { 맞춤형 새마을운동 } \\
\text { 지원사업 }\end{array}$ & $\begin{array}{l}\text { 키르기즈 새마을운동 } \\
\text { 시범마을 조성 및 관 } \\
\text { 리 }\end{array}$ & 프로젝트 & 7.77 & 1.58 & 계속 & $2017-2021$ & 양자무상 & 1 \\
\hline 6 & $\begin{array}{l}\text { 맞춤형 새마을운동 } \\
\text { 지원사업 }\end{array}$ & $\begin{array}{l}\text { 미얀마 새마을운동 시 } \\
\text { 범마을 조성 및 관리 }\end{array}$ & 프로젝트 & 2.62 & 0.34 & 계속 & $2017-2021$ & 양자무상 & 2 \\
\hline
\end{tabular}




\begin{tabular}{|c|c|c|c|c|c|c|c|c|c|}
\hline & 세부사업명 & 내역사업명 & 사업 유형 & $\begin{array}{c}\begin{array}{c}\text { 총사업 예산 } \\
\text { (억원) }\end{array} \\
\end{array}$ & $\begin{array}{l}\text { '18년예산 } \\
\text { (억원) }\end{array}$ & $\begin{array}{l}\text { 신규/ } \\
\text { 계속 }\end{array}$ & $\begin{array}{l}\text { 총사업 } \\
\text { 기간 }\end{array}$ & $\begin{array}{c}\text { 구분 } \\
\text { (양-다자) }\end{array}$ & $\begin{array}{l}\text { SDGs } \\
\text { 목표 }\end{array}$ \\
\hline & $\begin{array}{l}\text { 맞춤형 새마을운동 } \\
\text { 지원사업 }\end{array}$ & \begin{tabular}{l|}
$\begin{array}{l}\text { 몽골 새마을운동 시범 } \\
\text { 마을 조성 및 관리 }\end{array}$
\end{tabular} & 프로젝트 & 2.47 & 0.43 & 계속 & $2015-2019$ & 양자무상 & 1 \\
\hline & $\begin{array}{l}\text { 맞춤형 새마을운동 } \\
\text { 지원사업 }\end{array}$ & $\begin{array}{l}\text { 네팔 새마을운동 시범 } \\
\text { 마을 조성 및 관리 }\end{array}$ & 프로젝트 & 1.65 & 0.32 & 계속 & $2015-2019$ & 양자무상 & 2 \\
\hline & $\begin{array}{l}\text { 맞춤형 새마을운동 } \\
\text { 지원사업 }\end{array}$ & \begin{tabular}{|l|} 
캄보디아 새마을운동 시 \\
범마을 조성 및 관리
\end{tabular} & 프로젝트 & 1.90 & 0.30 & 계속 & $2015-2019$ & 양자무상 & 2 \\
\hline & $\begin{array}{l}\text { 맞춤형 새마을운동 } \\
\text { 지원사업 }\end{array}$ & $\begin{array}{l}\text { 탄자니아 새마을운동 시 } \\
\text { 범마을 조성 및 관리 }\end{array}$ & 프로젝트 & 1.82 & 0.34 & 계속 & $2015-2019$ & 양자무상 & 1 \\
\hline & $\begin{array}{l}\text { 맞춤형 새마을운동 } \\
\text { 지원사업 }\end{array}$ & $\begin{array}{l}\text { 부룬디 새마을운동 시 } \\
\text { 범마을 조성 및 관리 }\end{array}$ & 프로젝트 & 1.30 & 0.26 & 신규 & $2018-2022$ & 양자무상 & 1 \\
\hline & $\begin{array}{l}\text { 맞춤형 새마을운동 } \\
\text { 지원사업 }\end{array}$ & $\begin{array}{l}\text { 파푸아뉴기니 새마을 } \\
\text { 운동 시범마을 조성 } \\
\text { 및 관리 }\end{array}$ & 프로젝트 & 8.00 & 1.6 & 신규 & $2018-2022$ & 양자무상 & 1 \\
\hline & $\begin{array}{l}\text { 전자정부 국가 간 협 } \\
\text { 력 강화 }\end{array}$ & $\begin{array}{l}\text { 인도네시아 전자정부 } \\
\text { 협력센터 운영 }\end{array}$ & 개발컨설팅 & 14.85 & 4.95 & 계속 & 2016 2018 & 양자무상 & 9 \\
\hline & $\begin{array}{l}\text { 전자정부 국가 간 협 } \\
\text { 력 강화 }\end{array}$ & $\begin{array}{l}\text { 페루 전자정부 협력센 } \\
\text { 터 운영 }\end{array}$ & 개발컨설팅 & 14.56 & 4.95 & 신규 & 2017 2019 & 양자무상 & 9 \\
\hline & $\begin{array}{l}\text { 전자정부 국가 간 협 } \\
\text { 력 강화 }\end{array}$ & $\begin{array}{l}\text { 케냐 젖자정부 협력센 } \\
\text { 터 운영 }\end{array}$ & 개발컨설팅 & 14.56 & 4.95 & 계속 & 2017 2019 & 양자무상 & 9 \\
\hline & \begin{tabular}{|l|} 
전자정부분야 국제기 \\
구 교류협력
\end{tabular} & 전자정부 초청연수 & 연수사업 & 5.11 & 5.11 & 신규 & 2018 & 양자무상 & 9 \\
\hline & $\begin{array}{l}\text { 국제 기록관리 연수 } \\
\text { 과정 }\end{array}$ & $\begin{array}{l}\text { 국제 기록관리 연수 } \\
\text { 과정(우즈베키스탄, } \\
\text { 카자흐스탄) }\end{array}$ & 연수사업 & 0.64 & 0.64 & 신규 & 2018 2018 & 양자무상 & 17 \\
\hline & $\begin{array}{l}\text { 국제 기록관리 연수 } \\
\text { 과정 }\end{array}$ & $\begin{array}{l}\text { 국제 기록관리 연수 } \\
\text { 과정(모잠비크, 탄자 } \\
\text { 니아) }\end{array}$ & 연수사업 & 0.74 & 0.74 & 신규 & 2018 2018 & 양자무상 & 17 \\
\hline & $\begin{array}{l}\text { 우간다 농촌개발을 } \\
\text { 위한 새마을금고 프로 } \\
\text { 젝트 }\end{array}$ & $\begin{array}{l}\text { 우간다 농촌개발을 위 } \\
\text { 한 새마을금고 프로 } \\
\text { 젝트 }\end{array}$ & 프로젝트 & 6.95 & 2.65 & 신규 & $\begin{array}{c}2018 \sim \\
2020\end{array}$ & 양자무상 & 1 \\
\hline & $\begin{array}{l}\text { 외국지방공무원 교육 } \\
\text { 운영 }\end{array}$ & \begin{tabular}{|l|} 
몽골 NAOG 교수요원 \\
역량강화과정
\end{tabular} & 연수사업 & 0.63 & 0.63 & 신규 & 2018 & 양자무상 & 16 \\
\hline & $\begin{array}{l}\text { 외국지방공무원 교육 } \\
\text { 운영 }\end{array}$ & 몽골 군수 역량강화과정 & 연수사업 & 0.63 & 0.63 & 신규 & 2018 & 양자무상 & 16 \\
\hline & $\begin{array}{l}\text { 외국지방공무원 교육 } \\
\text { 운영 }\end{array}$ & 개도국 지방행정과정 & 연수사업 & 1.14 & .14 & 신규 & 2018 & 양자무상 & 17 \\
\hline & $\begin{array}{l}\text { 외국지방공무원 교육 } \\
\text { 운영 }\end{array}$ & 현지 방문교육 & 기타기술협력 & 0.67 & 0.67 & 신규 & 매년 & 양자무상 & 4 \\
\hline & $\begin{array}{l}\text { 미얀마 바간 사진 아 } \\
\text { 카이브 보존 및 디지 } \\
\text { 털화 사업 }\end{array}$ & $\begin{array}{l}\text { 미얀마바간사진아카이 } \\
\text { 브보존및디지털화사업 } \\
\text { (UNESCO) }\end{array}$ & 프로그램 & 6.00 & 3.00 & 신규 & 2018 2019 & 다자성양자 & 17 \\
\hline & 전자정부분야 국제기 & $\begin{array}{l}\text { UN무역개발회의 } \\
\text { (UNCTAD) 분담금 } \\
\text { 납부 }\end{array}$ & 기타기술협력 & & 0.81 & 계속 & $2011 \sim$ & 다자성양자 & 17 \\
\hline & \begin{tabular}{|l|} 
UN거버넌스센터사업 \\
지원 \\
(대한민국정부와국제 \\
연합간의기술협력신탁 \\
기금협정)
\end{tabular} & \begin{tabular}{|l|}
$\begin{array}{l}\text { UN거버넌스센터사업 } \\
\text { 지원 } \\
\text { (대한민국정부와국제 } \\
\text { 연합간의기술협력신탁 } \\
\text { 기금협정) }\end{array}$
\end{tabular} & 기타 & & 26.17 & 계속 & $2006-2030$ & 다자성양자 & 17 \\
\hline
\end{tabular}


$\square$ 총괄

(단위: 억원)

\begin{tabular}{l|c|c|c||c|c|c}
\hline \multirow{2}{*}{$\mathrm{ODA}$ 시행부처(기관) } & \multicolumn{3}{|c||}{2017} & \multicolumn{3}{c}{2018 (요구) } \\
\cline { 2 - 7 } & 양자 무상 & 다자 & 합계 & 양자 무상 & 다자 & 합계 \\
\hline 문화체육관광부 & 110.8 & - & 110.8 & 148.7 & - & 148.7 \\
\hline
\end{tabular}

※ 다자성양자는 양자에 포함

○ '18년도 ODA 시행목표

- 개발도상국의 문화예술, 체육, 관광 분야 역량 강화를 통한 문화향유권 증 대, 문화산업 발전 및 문화를 통한 수원국의 사회통합에 기여

으주요 정책과제

- 한국의 문화발전 경험을 바탕으로 한 다양한 신규 사업 발굴 및 한국형 문화 $\mathrm{ODA}$ 모델 구축을 통한 체계적이고 내실 있는 문화ODA 추진

- 초청연수, 장학지원, 전문가파견, 문화 관련 인프라 구축 지원 등을 통해 개도국 문화 분야 공무원 및 관계자 역량제고, 지역주민의 문화향유 여건 개선

- 문화ODA 사후관리시스템 체계화를 통한 사업의 지속가능성 제고

- 국제기구, 타 기관과의 연계·협업 증진

$\square$ 유형별 분류

(억원, \%)

\begin{tabular}{|c|c|c|c|c|c|c|c|c|c|c|c|c|}
\hline \multirow[b]{2}{*}{ 구분 } & \multirow[b]{2}{*}{ 계 } & \multirow[b]{2}{*}{$\begin{array}{l}\text { 프로 } \\
\text { 젝트 }\end{array}$} & \multirow[b]{2}{*}{$\begin{array}{l}\text { 프로 } \\
\text { 르램 }\end{array}$} & \multirow[b]{2}{*}{$\begin{array}{l}\text { 개발 } \\
\text { 컨설팅 }\end{array}$} & \multicolumn{4}{|c|}{ 기술협력 } & \multirow{2}{*}{$\begin{array}{c}\text { 민관 } \\
\text { 협력 } \\
\text { (NGO, } \\
\text { 기업) } \\
\end{array}$} & \multirow[b]{2}{*}{$\begin{array}{l}\text { 행정 } \\
\text { 비용 }\end{array}$} & \multirow[b]{2}{*}{ 기타 } & \multirow[b]{2}{*}{$\begin{array}{l}\text { 순수 } \\
\text { 다자* }\end{array}$} \\
\hline & & & & & $\begin{array}{l}\text { 연수 } \\
\text { 사업 }\end{array}$ & $\begin{array}{l}\text { 장학 } \\
\text { 지원 }\end{array}$ & $\begin{array}{l}\text { 봉사단 } \\
\text { 파견 }\end{array}$ & $\begin{array}{l}\text { 기타 } \\
\text { 기술 } \\
\text { 협력 }\end{array}$ & & & & \\
\hline , 17녀 & 110.8 & 63.3 & $\therefore$ & $\therefore$ & 63.3 & 28.6 & 1.1 & 5.9 & - & $\begin{array}{ll}- \\
\cdots\end{array}$ & 12.0 & $\therefore$ \\
\hline 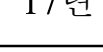 & 100 & 57.1 & $\begin{array}{l}\cdots \\
-\end{array}$ & - & 57.1 & 25.8 & 1.0 & 5.3 & - & - & 10.8 & - \\
\hline '18년 & 148.7 & 22.3 & - & 5.5 & 80.5 & 34.8 & - & 4.0 & - & - & 1.6 & - \\
\hline (요구) & 100 & 15.0 & - & 3.7 & 54.1 & 23.4 & - & 2.7 & - & - & 1 & - \\
\hline
\end{tabular}

* 다자성양자를 제외한 순수다자만 해당되며, 다자성양자는 사업 유형에 맞게 분류

$\square$ 총 사업 목록

\begin{tabular}{|c|c|c|c|c|c|c|c|c|c|}
\hline & 세부사업명 & 내역사업명 & 사업 유형 & $\begin{array}{c}\text { 총사업예산 } \\
\text { (억원) }\end{array}$ & $\begin{array}{l}\text { '18년예산 } \\
\text { (억원) }\end{array}$ & $\begin{array}{l}\text { 신규/ } \\
\text { 계속 }\end{array}$ & $\begin{array}{l}\text { 총사업 } \\
\text { 기간 }\end{array}$ & $\begin{array}{c}\text { 구분 } \\
\text { (양-다자) }\end{array}$ & $\begin{array}{l}\text { SDGs } \\
\text { 목표 }\end{array}$ \\
\hline 1 & $\begin{array}{l}\text { 개도국 문화자원 역량 } \\
\text { 강화ODA }\end{array}$ & 문화동반자사업 & 연수사업 & 12.15 & 12.15 & 신규 & 2018 & 양자무상 & 17 \\
\hline 2 & $\begin{array}{l}\text { 개도국 문화자원 역량 } \\
\text { 강화ODA }\end{array}$ & $\begin{array}{l}\text { 인도네시아 전통음악 } \\
\text { 진흥을 위한 한-인 } \\
\text { 니 지식공유 사업 }\end{array}$ & 개발컨설팅 & 7.00 & 5.50 & 신규 & $\begin{array}{c}2018 \sim 201 \\
9\end{array}$ & 양자무상 & 11 \\
\hline 3 & 해외작은도서관조성 & $\begin{array}{l}\text { 고맙습니다. 작은도서 } \\
\text { 관 조성 지원(몽골) }\end{array}$ & 프로젝트 & 1.80 & 1.80 & 신규 & 2018 & 양자무상 & 4 \\
\hline 4 & 해외작은도서관조성 & $\begin{array}{l}\text { 고맙습니다. 작은도서관 } \\
\text { 조성 지원(베트남) }\end{array}$ & 프로젝트 & 1.80 & 1.80 & 신규 & 2018 & 양자무상 & 4 \\
\hline 5 & 해외작은도서관조성 & $\begin{array}{l}\text { 고맙습니다. 작은도서관 } \\
\text { 조성 지원(탄자니아) }\end{array}$ & 프로젝트 & 3.90 & 3.90 & 신규 & 2018 & 양자무상 & 4 \\
\hline
\end{tabular}




\begin{tabular}{|c|c|c|c|c|c|c|c|c|c|}
\hline & 세부사업명 & 내역사업명 & 사업 유형 & $\begin{array}{l}\begin{array}{l}\text { 총사업 예산 } \\
\text { (억원) }\end{array} \\
\end{array}$ & $\begin{array}{l}18 \text { 년예산 } \\
\text { (억원) }\end{array}$ & $\begin{array}{l}\text { 신규/ } \\
\text { 계속 }\end{array}$ & $\begin{array}{l}\text { 총사업 } \\
\text { 기간 } \\
\end{array}$ & $\begin{array}{c}\text { 구분 } \\
\text { (양-다자) }\end{array}$ & $\begin{array}{l}\text { SDGs } \\
\text { 목표 }\end{array}$ \\
\hline 6 & 문화예술ODA & $\begin{array}{l}\text { 문화예술교육ODA(베 } \\
\text { 트남) }\end{array}$ & 기타기술협력 & 8.00 & 2.00 & 신규 & 2018 2021 & 양자무상 & 4 \\
\hline 7 & 문화예술ODA & $\begin{array}{l}\text { 문화예술교육ODA(인 } \\
\text { 도네시아) }\end{array}$ & 기타기술협력 & 18.00 & 2.00 & 신규 & $2018 \sim 2022$ & 양자무상 & 4 \\
\hline 8 & $\begin{array}{l}\text { 저개발국 관광지도자 } \\
\text { 벤치마킹 사업연수 } \\
\text { (ODA) }\end{array}$ & $\begin{array}{l}\text { 저개발국 관광지도자 } \\
\text { 벤치마킹 연수 사업 }\end{array}$ & 연수사업 & 15.00 & 15.00 & 신규 & 2018 & 양자무상 & 17 \\
\hline 9 & $\begin{array}{l}\text { 개도국 스포츠 발전 } \\
\text { 지원 }\end{array}$ & $\begin{array}{l}\text { 개도국 선수 합동훈련 } \\
\text { 과정 }\end{array}$ & 연수사업 & 6.55 & 6.55 & 신규 & 2018 & 양자무상 & 17 \\
\hline & $\begin{array}{l}\text { 개도국 스포츠 발전 } \\
\text { 지원 }\end{array}$ & $\begin{array}{l}\text { 개도국 스포츠지도자 } \\
\text { 교육과정 }\end{array}$ & 연수사업 & 14.42 & 14.42 & 신규 & 2018 & 양자무상 & 17 \\
\hline 11 & $\begin{array}{l}\begin{array}{l}\text { 개도국 스포츠 발전 } \\
\text { 지원 }\end{array} \\
\end{array}$ & $\begin{array}{l}\text { 개도국 스포츠행정가 } \\
\text { 교육과정 }\end{array}$ & 장학지원 & 22.27 & 22.27 & 신규 & 2018 & 양자무상 & 16 \\
\hline 12 & $\begin{array}{l}\text { 개도국 스포츠 발전 } \\
\text { 지원 }\end{array}$ & $\begin{array}{l}\text { 스포츠동반자 프로그 } \\
\text { 램 }\end{array}$ & 연수사업 & 15.72 & 15.72 & 신규 & 2018 & 양자무상 & 17 \\
\hline 13 & $\begin{array}{l}\text { 개도국 스포츠 발전 } \\
\text { 지원 }\end{array}$ & $\begin{array}{l}\text { 라오스 야구장 건립 } \\
\text { 지원 }\end{array}$ & 프로젝트 & 9.00 & 4.8 & 신규 & $2018 \sim 2019$ & 양자무상 & 4 \\
\hline 14 & 아시아예술계인력양성 & $\begin{array}{l}\text { Art Major } \\
\text { Asian(AMA) 장학사 } \\
\text { 업 }\end{array}$ & 장학지원 & 12.52 & 12.52 & 신규 & 2018 & 양자무상 & 4 \\
\hline 15 & 아시아예술계인력양성 & $\begin{array}{l}\text { AMFEK 초청연수사 } \\
\text { 업 }\end{array}$ & 연수사업 & 10.00 & 10.00 & 신규 & 2018 & 양자무상 & 17 \\
\hline & $\begin{array}{l}\text { 유네스코 세종문해상 } \\
\text { 지원 }\end{array}$ & $\begin{array}{l}\text { 유네스코 세종문해상 } \\
\text { 지원 }\end{array}$ & 기타 & 1.24 & 1.24 & 계속 & $\begin{array}{l}1990- \\
\text { 계속 }\end{array}$ & 다자성양자 & 4 \\
\hline 17 & $\begin{array}{l}\text { WIPO 신탁기금 지 } \\
\text { 원 }\end{array}$ & WIPO 신탁기금 지원 & 기타 & 10.72 & 0.32 & 계속 & $\begin{array}{l}2007- \\
\text { 계속 }\end{array}$ & 다자성양자 & 16 \\
\hline 1 & $\begin{array}{l}\text { 아시아문화역량 강화 } \\
\text { 지원 }\end{array}$ & $\begin{array}{l}\text { 미얀마 문화예술 활용 } \\
\text { 역량 강화 지원 사업 }\end{array}$ & 프로젝트 & 20.00 & 10.00 & 신규 & $2018 \sim 2019$ & 양자무상 & 16 \\
\hline 19 & $\begin{array}{l}\text { 언론인 역량강화 및 } \\
\text { 인적개발 사업 }\end{array}$ & $\begin{array}{l}\text { 언론인 역량강화 및 } \\
\text { 인적개발 사업 }\end{array}$ & 연수사업 & 54.16 & 6.67 & 신규 & 2018 2023 & 양자무상 & 17 \\
\hline
\end{tabular}


$\square$ 총괄

(단위: 억원)

\begin{tabular}{l|c|c|c||c|c|c}
\hline \multirow{2}{*}{ ODA 시행부처(기관) } & \multicolumn{3}{|c||}{2017} & \multicolumn{3}{c}{2018 (요구) } \\
\cline { 2 - 7 } & 양자 무상 & 다자 & 합계 & 양자 무상 & 다자 & 합계 \\
\hline 농림축산식품부 & 180.9 & 89.0 & 269.9 & 672.3 & 92.0 & 764.3 \\
\hline
\end{tabular}

※ 다자성양자는 양자에 포함

○ '18년도 ODA 시행목표

- 우리나라 농업·농촌개발의 경험을 개도국에 전수하여 개도국의 농가소득 향상과 지속가능한 농업발전에 기여

- 사업 대상국가·유망분야에 ODA 사업을 연계·추진, 기업의 해외진출 지원 * 민-관 협의체를 운영하여, 중점지원국을 대상으로 ODA 사업 발굴

으주요 정책과제

- 우리기업의 해외진출 가능성이 큰 분야를 대상으로 ODA와 연계 중점 추진

- 전문화·차별화 전략을 통하여 협력사업 표준모델을 개발·활용, 농업·농촌 개발 분야에서의 주도적인 역할 강화

* 협력대상국의 이익 증대 및 사업 효과성 제고를 위한 사업 발굴·확대 추진

$\square$ 유형별 분류

(억 원, \%)

\begin{tabular}{|c|c|c|c|c|c|c|c|c|c|c|c|c|}
\hline \multirow[b]{2}{*}{ 구분 } & \multirow[b]{2}{*}{ 계 } & \multirow[b]{2}{*}{ 프로 } & \multirow[b]{2}{*}{$\begin{array}{l}\text { 프로 } \\
\text { 그램 }\end{array}$} & \multirow[b]{2}{*}{$\begin{array}{l}\text { 개발 } \\
\text { 컨설팅 }\end{array}$} & \multicolumn{4}{|c|}{ 기술협력 } & \multirow{2}{*}{$\begin{array}{c}\text { 민관 } \\
\text { 협력 } \\
\text { (NGO, } \\
\text { 기업) }\end{array}$} & \multirow[b]{2}{*}{$\begin{array}{l}\text { 행 정 } \\
\text { 비용 }\end{array}$} & \multirow[b]{2}{*}{ 기타 } & \multirow[b]{2}{*}{$\begin{array}{l}\text { 순수 } \\
\text { 다자* }\end{array}$} \\
\hline & & & & & $\begin{array}{l}\text { 연수 } \\
\text { 사업 }\end{array}$ & $\begin{array}{l}\text { 장학 } \\
\text { 지원 }\end{array}$ & $\begin{array}{l}\text { 봉사단 } \\
\text { 파견 }\end{array}$ & $\begin{array}{l}\text { 기타 } \\
\text { 기술 } \\
\text { 협력 }\end{array}$ & & & & \\
\hline \multirow{2}{*}{ '17년 } & 269.9 & 150.8 & - & 12.0 & 4.2 & - & $\therefore$ & 0.7 & - & 7.0 & 6.3 & 89.0 \\
\hline & 100 & 55.9 & - & 4.4 & 1.5 & - & $\begin{array}{c}\cdots \\
-\end{array}$ & 0.3 & $\begin{array}{c}\cdots \\
-\end{array}$ & 2.6 & 2.3 & 33.0 \\
\hline '18년 & 764.3 & 652.7 & - & 12.0 & 6.1 & - & - & - & - & - & 1.5 & 92.0 \\
\hline (요구) & 100 & 85.4 & - & 1.5 & 0.8 & - & - & - & - & - & 0.2 & 12.0 \\
\hline
\end{tabular}

* 다자성양자를 제외한 순수다자만 해당되며, 다자성양자는 사업 유형에 맞게 분류

$\square$ 총 사업 목록

\begin{tabular}{|c|c|c|c|c|c|c|c|c|c|}
\hline & 세부사업명 & 내역사업명 & 사업 유형 & $\begin{array}{l}\text { 총사업 예산 } \\
\text { (억원) }\end{array}$ & $\begin{array}{l}\text { '18년예산 } \\
\text { (억원) }\end{array}$ & $\begin{array}{l}\text { 신규/ } \\
\text { 계속 }\end{array}$ & $\begin{array}{l}\text { 총사업 } \\
\text { 기간 }\end{array}$ & $\begin{array}{c}\text { 구분 } \\
\text { (양.다자) }\end{array}$ & $\begin{array}{l}\text { SDGS } \\
\text { 목표 }\end{array}$ \\
\hline 1 & 국제농업협력(ODA) & $\begin{array}{l}\text { 카메룬 벼 재배단지를 } \\
\text { 활용한 교육연구단지 } \\
\text { 조성사업 }\end{array}$ & 프로젝트 & 30.41 & 6.87 & 계속 & '14-'18 & 양자무상 & 2 \\
\hline 2 & 국제농업협력(ODA) & $\begin{array}{l}\text { 르완다 사료생산 및 } \\
\text { 수확후처리 지원사업 }\end{array}$ & 프로젝트 & 43.41 & 23.25 & 계속 & '14-'18 & 양자무상 & 2 \\
\hline 3 & 국제농업협력(ODA) & $\begin{array}{l}\text { 라오스 쌍통군 농촌개 } \\
\text { 발 및 영농기계기술 } \\
\text { 지원센터 구축사업 }\end{array}$ & 프로젝트 & 45.41 & 19.02 & 계속 & '15-'18 & 양자무상 & 2 \\
\hline 4 & 국제농업협력(ODA) & $\begin{array}{l}\text { 캄보디아 쌀산업 발전 } \\
\text { 을 위한 건조저장시 } \\
\text { 설 구축사업 }\end{array}$ & 프로젝트 & 30.41 & 14.59 & 계속 & '15-'18 & 양자무상 & 2 \\
\hline 5 & 국제농업협력(ODA) & $\begin{array}{l}\text { 필리핀 MIC사업지구 } \\
\text { 농촌개발사업 }\end{array}$ & 프로젝트 & 27.41 & 2.11 & 계속 & '15-'18 & 양자무상 & 2 \\
\hline
\end{tabular}




\begin{tabular}{|c|c|c|c|c|c|c|c|c|c|}
\hline & 세부사업명 & 내역사업명 & 사업 유형 & $\begin{array}{l}\begin{array}{l}\text { 총사업예산 } \\
\text { (억 원) }\end{array} \\
\end{array}$ & $\begin{array}{l}\text { '18년예산 } \\
\text { (억원) }\end{array}$ & $\begin{array}{l}\text { 신규/ } \\
\text { 계속 }\end{array}$ & $\begin{array}{l}\text { 총사업 } \\
\text { 기간 }\end{array}$ & \begin{tabular}{c|} 
구분 \\
(양.다자) \\
\end{tabular} & $\begin{array}{l}\text { SDGs } \\
\text { 목표 }\end{array}$ \\
\hline 6 & 국제농업협력(ODA) & \begin{tabular}{|l|} 
가나 아쿠마단 농촌개 \\
발 및 채소단지 관개 \\
사업
\end{tabular} & 프로젝트 & 37.41 & 17.75 & 계속 & '15-'18 & 양자무상 & 2 \\
\hline 7 & 국제농업협력(ODA) & $\begin{array}{l}\text { 미얀마 농업생산성 증 } \\
\text { 대를 위한 건조저장 } \\
\text { 시설 구축사업 }\end{array}$ & 프로젝트 & 38.84 & 10.96 & 계속 & '16-'19 & 양자무상 & 2 \\
\hline 8 & 국제농업협력(ODA) & $\begin{array}{l}\text { 에티오피아 하라리주 } \\
\text { 관개시설 구축사업 }\end{array}$ & 프로젝트 & 36.26 & 5.29 & 계속 & '16-'20 & 양자무상 & 2 \\
\hline 9 & 국제농업협력(ODA) & $\begin{array}{l}\text { 우즈베키스탄 시설농 } \\
\text { 업 지원 및 } \\
\text { 사이술접수 }\end{array}$ & 프로젝트 & 40.84 & 6.34 & 계속 & $\begin{array}{r}2016-201 \\
9\end{array}$ & 양자무상 & 2 \\
\hline 10 & 국제농요 & \begin{tabular}{|l|} 
볼리비아 씨감자 생산 \\
체계 구축 및 생산기 \\
술 전수사업
\end{tabular} & 프로젝트 & 41.26 & 6.34 & 계속 & '16-'19 & 양자무상 & 2 \\
\hline 11 & 국제농요 & $\begin{array}{l}\text { 캄보디아 영농기술전 } \\
\text { 수를 통한 농업생산 } \\
\text { 성 증대 사업 }\end{array}$ & 프로젝트 & 41.68 & 7.40 & 계속 & '17-'21 & 양자무상 & 2 \\
\hline 12 & (ODA) & $\begin{array}{l}\text { 에티오피아 농가소득 } \\
\text { 향상을 위한 농업기 } \\
\text { 술 보급사업 }\end{array}$ & 프로젝트 & 31.26 & 5.29 & 계속 & '17-'20 & 양자무상 & 2 \\
\hline 13 & 국제농업협력(ODA) & $\begin{array}{l}\text { 에티오피아 곡물가공 } \\
\text { 기술 전수사업 }\end{array}$ & 프로젝트 & 16.84 & 3.65 & 계속 & '17-'19 & 양자무상 & 2 \\
\hline 14 & (ODA) & $\begin{array}{l}\text { 우간다 곡물가공기술 } \\
\text { 전수사업 }\end{array}$ & 프로젝트 & 16.84 & 3.65 & 계속 & '17-'19 & 양자무상 & 2 \\
\hline 15 & 국제농업협력(ODA) & $\begin{array}{l}\text { 베트남 우수농산물 저 } \\
\text { 장 유통센터 지원사 } \\
\text { 업 }\end{array}$ & 프로젝트 & 32.10 & 1.59 & 신규 & $\begin{array}{r}2018-202 \\
2\end{array}$ & 양자무상 & 2 \\
\hline 16 & 국제농업협력(ODA) & $\begin{array}{l}\text { 에티오피아 낙농기술 } \\
\text { 지원을 통한 생산성 } \\
\text { 향상사업 }\end{array}$ & 프로젝트 & 31.68 & 1.59 & 신규 & '18-'21 & 양자무상 & 2 \\
\hline 17 & 력(ODA) & \begin{tabular}{|l|} 
우간다 낙농기술지원 \\
을 통한 생산성 향상 \\
사업
\end{tabular} & 프로젝트 & 31.26 & 1.59 & 신규 & '18-'20 & 양자무상 & 2 \\
\hline 18 & 력(ODA) & \begin{tabular}{|l|} 
모잠비크 소농을 위한 \\
농업기술 보급체계 \\
강화사업
\end{tabular} & 프로젝트 & 42.10 & 1.59 & 신규 & '18-'22 & 양자무상 & 2 \\
\hline 19 & ODA） & $\begin{array}{l}\text { 개도국 식량안보를 위 } \\
\text { 한 우리나라 농정 성 } \\
\text { 과확산 사업(몽골) }\end{array}$ & 개발컨설팅 & 3.80 & 3.80 & 신규 & 2018 & 양자무상 & 2 \\
\hline 20 & ODA） & \begin{tabular}{|l|} 
개도국 식량안보를 위 \\
한 우리나라 농정 성 \\
과확산 사업(캄보디 \\
아)
\end{tabular} & 개발컨설팅 & 3.71 & 3.71 & 신규 & 2018 & 양자무상 & 2 \\
\hline 21 & DA） & $\begin{array}{l}\text { 개도국 식량안보를 위 } \\
\text { 한 우리나라 농정 성 } \\
\text { 과확산 사업(라오스) }\end{array}$ & 개발컨설팅 & 4.49 & 4.49 & 신규 & 2018 & 양자무상 & 2 \\
\hline 22 & 동식물검역 & $\begin{array}{l}\text { 개도국 식물검역전문 } \\
\text { 가 역량 강화 사업 }\end{array}$ & 수사업 & 1.90 & 1.90 & 신규 & 2018 & 양자무상 & 2 \\
\hline 23 & 동식물검역검사ODA & $\begin{array}{l}\text { 개도국 국경검역시스 } \\
\text { 템 구축지원 }\end{array}$ & 프로젝트 & 0.54 & 0.54 & 계속 & 2018 & 양자무상 & 2 \\
\hline & $\begin{array}{l}\text { 아시아 개도국 농산 } \\
\text { 물 안전성 관련 관계 } \\
\text { 관 초청연수 }\end{array}$ & $\begin{array}{l}\text { 아시아 개도국 농산물 } \\
\text { 안전성 관련 관계관 } \\
\text { 초청연수 }\end{array}$ & 연수사업 & 0.71 & 0.71 & 신규 & 2018(4주) & 양자무상 & 3 \\
\hline $2 !$ & $\begin{array}{l}\text { 종자산업 및 품종보 } \\
\text { 호(ODA) }\end{array}$ & $\begin{array}{l}\text { 아시아 종자산업 발전 } \\
\text { 을 위한 역량강화 연 } \\
\text { 수 }\end{array}$ & 연수사업 & 0.85 & 0.85 & 신규 & 2018(2주) & 양자무상 & 2 \\
\hline 26 & 국제농업협력(ODA) & \begin{tabular}{|l|} 
아세안+3식량안보정 \\
보시스템2단계협력 \\
(필리핀 국가농식품정 \\
보시스템 구축)
\end{tabular} & 프로젝트 & 23.00 & 5.00 & 신규 & $\begin{array}{r}2018-202 \\
0\end{array}$ & 양자무상 & 2 \\
\hline
\end{tabular}




\begin{tabular}{|c|c|c|c|c|c|c|c|c|c|}
\hline & 세부사업명 & 내역사업명 & 사업 유형 & $\begin{array}{c}\text { 총사업 예산 } \\
\text { (억원) }\end{array}$ & $\begin{array}{l}\text { '18년예산 } \\
\text { (억원) }\end{array}$ & $\begin{array}{l}\text { 신규/ } \\
\text { 계속 }\end{array}$ & $\begin{array}{l}\text { 총사업 } \\
\text { 기간 }\end{array}$ & $\begin{array}{c}\text { 구분 } \\
\text { (양-다자) }\end{array}$ & $\begin{array}{l}\text { SDGs } \\
\text { 목표 }\end{array}$ \\
\hline 27 & 국제농업협력(ODA) & $\begin{array}{l}\text { 아세안+3식량안보정 } \\
\text { 보시스템2단계혁력 } \\
\text { (라오스 국가농식품정 } \\
\text { 보시스템 구축) }\end{array}$ & 프로젝트 & 23.00 & 4.00 & 신규 & $\begin{array}{r}2018-202 \\
0\end{array}$ & 양자무상 & 2 \\
\hline 28 & 국제농업협력(ODA) & 타당성 조사 & 프로젝트 & 3.60 & 3.60 & 신규 & 2018 & 양자무상 & 2 \\
\hline 29 & 국제농업협력(ODA) & 사후관리 & 프로젝트 & 2.00 & 2.00 & 신규 & 2018 & 양자무상 & 2 \\
\hline 30 & 국제농업협력(ODA) & 평가 & 기타 & 1.50 & 1.50 & 계속 & 2011 계속 & 양자무상 & \\
\hline 31 & 국제농업협력(ODA) & $\begin{array}{l}\text { 축산물의 생산 및 유 } \\
\text { 통체계 개선(베트남) }\end{array}$ & 연수사업 & 3.20 & 0.80 & 신규 & $\begin{array}{r}2018 \sim 202 \\
1 \\
\end{array}$ & 양자무상 & 2 \\
\hline 32 & 국제농업협력(ODA) & $\begin{array}{l}\text { 축산물 품질평가 및 } \\
\text { 이력시스템 정착(인 } \\
\text { 도네시아) }\end{array}$ & 연수사업 & 3.20 & 0.80 & 신규 & $\begin{array}{r}2018 \sim 202 \\
1\end{array}$ & 양자무상 & 4 \\
\hline 33 & 국제농업협력(ODA) & $\begin{array}{l}\text { 축산물이력제 및 축산 } \\
\text { 물품질평가 제도 구 } \\
\text { 축(르완다) }\end{array}$ & 연수사업 & 4.00 & 1.00 & 신규 & $\begin{array}{r}2018 \sim 202 \\
1\end{array}$ & 양자무상 & 2 \\
\hline 34 & 국제농업협력 & $\begin{array}{l}\text { 농식품부-FAO 간 식 } \\
\text { 량안보 협력사업(개 } \\
\text { 도국 조류 인플루엔자 } \\
\text { 대응 능력 제고 사업) }\end{array}$ & 프로젝트 & 30.00 & 8.66 & 계속 & $\begin{array}{r}2015-201 \\
8\end{array}$ & 다자성양자 & 2 \\
\hline 35 & 국제농업협력 & $\begin{array}{l}\text { 농식품부-FAO 간 식 } \\
\text { 량안보 협력사업(채 } \\
\text { 소 및 과실 장려 프로 } \\
\text { 그램 지원) }\end{array}$ & 프로젝트 & 18.52 & 3.20 & 신규 & $\begin{array}{r}2018-202 \\
3\end{array}$ & 다자성양자 & 2 \\
\hline 36 & 국제농업협력 & $\begin{array}{l}\text { 농식품부-FAO 간 식 } \\
\text { 량안보 협력사업(베 } \\
\text { 트남 가뭄조기경보시 } \\
\text { 스템 구축을 통하 농 } \\
\text { 업기후정보시스템 강 } \\
\text { 화) }\end{array}$ & 프로젝트 & 19.09 & 5.70 & 신규 & $\begin{array}{r}2018-202 \\
0\end{array}$ & 다자성양자 & 2 \\
\hline 37 & 국제농업협력 & $\begin{array}{l}\text { 농식품부-FAO 간 식 } \\
\text { 량안보 협력사업(한국 } \\
\text {-FAO-수계국 삼자협 } \\
\text { 력을 통한 개도국 쌀 } \\
\text { 기술 및 교육 허브 구 } \\
\text { 축) }\end{array}$ & 프로젝트 & 33.86 & 6.11 & 신규 & $\begin{array}{r}2018-202 \\
1\end{array}$ & 다자성양자 & 2 \\
\hline 38 & 국제농업협력 & $\begin{array}{l}\text { 농식품부 - IFAD간 } \\
\text { 공동협력 보충기금사 } \\
\text { 업(ICT를 활용한 농 } \\
\text { 업기술지도 및 정보시 } \\
\text { 스템 구축사업) }\end{array}$ & 프로젝트 & 20.00 & 5.00 & 계속 & $\begin{array}{r}2016-201 \\
9\end{array}$ & 다자성양자 & 2 \\
\hline 39 & 국제농업협력 & $\begin{array}{l}\text { 농식품부 - IFAD간 } \\
\text { 공동협력 보충기금사 } \\
\text { 업(남태평양 주요도서 } \\
\text { 국 농림수산식품 생산 } \\
\text { 기반 및 유통구조 개 } \\
\text { 선사업) }\end{array}$ & 프로젝트 & 20.00 & 5.00 & 계속 & $\begin{array}{r}2015-201 \\
8\end{array}$ & 다자성양자 & 2 \\
\hline 40 & 국제농업협력 & 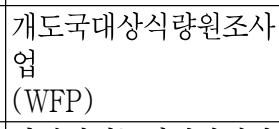 & 프로젝트 & & 460.00 & 신규 & 2018-계속 & 다자성양자 & 2 \\
\hline 41 & 국제농업협력 & $\begin{array}{l}\text { 아태지역농업및가치사 } \\
\text { 슬발전사업 } \\
\text { (ADB) }\end{array}$ & 프로젝트 & 20.00 & 5.00 & 신규 & $\begin{array}{r}2018-202 \\
1\end{array}$ & 다자성양자 & 2 \\
\hline 42 & 국제기구분담금 & $\begin{array}{l}\text { 국제농업개발기금 } \\
\text { (IFAD) 분담금 }\end{array}$ & & & 35.50 & 계속 & 1978 계속 & 다자 & \\
\hline & 국제기구분담금 & $\begin{array}{l}\text { 세계식량계획(WFP) } \\
\text { 분담금 }\end{array}$ & & & 1.15 & 계속 & 1981 계속 & 다자 & \\
\hline & $\begin{array}{l}\text { 국제식량농업기구 } \\
\text { (FAO) 분담금 }\end{array}$ & $\begin{array}{l}\text { 국제식량농업기구 } \\
\text { (FAO) 분담금 }\end{array}$ & & 108.60 & 55.39 & 계속 & 1949 계속 & 다자 & \\
\hline
\end{tabular}


$\square$ 총괄

(단위: 억원)

\begin{tabular}{l|c|c|c||c|c|c}
\hline \multirow{2}{*}{$\mathrm{ODA}$ 시행부처(기관) } & \multicolumn{3}{|c||}{2017} & \multicolumn{3}{c}{2018 (요구) } \\
\cline { 2 - 7 } & 양자 무상 & 다자 & 합계 & 양자 무상 & 다자 & 합계 \\
\hline 산업통상자원부 & 252.7 & 14.4 & 267.1 & 469.8 & 14.4 & 469.8 \\
\hline
\end{tabular}

※ 다자성양자는 양자에 포함

○ '18년도 ODA 시행목표

- 개도국과의 전략적인 산업협력 확대추진

으주요 정책과제

- 개도국의 산업발전 역량강화를 위한 시설·기자재·기술협력·컨설팅 등 지원을 위한 산업통상협력개발지원사업 확대

- 개도국 전력·에너지분야 역량강화 및 에너지산업협력 지원을 위한 에너지산업 협력개발지원사업 추진

- 기후변화협약 대응 개도국 역량강화 및 제도 수립 지원을 위한 한-개도국 협력 사업 지원

- 기술무역장벽 완화, 우리 기업의 수출 지원, 시험인증기관 해외진출 지원 등을 위해 개도국을 대상으로 한국형 표준·인증 체계를 전수

- 국제면화자문위원회, 아시아생산성기구 등 국제기구 분담금 집행

$\square$ 유형별 분류

(억 원, \%)

\begin{tabular}{|c|c|c|c|c|c|c|c|c|c|c|c|c|}
\hline \multirow[b]{2}{*}{ 구분 } & \multirow[b]{2}{*}{ 계 } & \multirow[b]{2}{*}{ 프로 } & \multirow[b]{2}{*}{$\begin{array}{l}\text { 프로 } \\
\text { 그램 }\end{array}$} & \multirow[b]{2}{*}{$\begin{array}{l}\text { 개발 } \\
\text { 컨설팅 }\end{array}$} & \multicolumn{4}{|c|}{ 기술협력 } & \multirow{2}{*}{\begin{tabular}{|c|} 
민관 \\
협력 \\
(NGO, \\
기업) \\
\end{tabular}} & \multirow[b]{2}{*}{$\begin{array}{l}\text { 행정 } \\
\text { 비용 }\end{array}$} & \multirow[b]{2}{*}{ 기타 } & \multirow[b]{2}{*}{$\begin{array}{l}\text { 순수 } \\
\text { 다자 }\end{array}$} \\
\hline & & & & & $\begin{array}{l}\text { 연수 } \\
\text { 사업 }\end{array}$ & $\begin{array}{l}\text { 장학 } \\
\text { 지원 }\end{array}$ & $\begin{array}{l}\text { 봉사단 } \\
\text { 파견 }\end{array}$ & $\begin{array}{l}\text { 기타 } \\
\text { 기술 } \\
\text { 협력 }\end{array}$ & & & & \\
\hline \multirow{2}{*}{ '17년 } & 267.1 & 179.4 & - & 22.8 & 6.5 & - & - & 22.0 & 10.0 & 6.0 & 6.0 & 14.4 \\
\hline & 100 & 67.2 & $\begin{array}{l}\cdots \\
-\end{array}$ & 8.5 & 2.4 & - & - & 3.2 & 3.7 & 2.2 & 2.2 & 5.4 \\
\hline '18년 & 469.8 & 400.4 & - & 17.1 & - & - & - & 23.0 & 15.0 & - & - & 14.4 \\
\hline (요구) & 100 & 85.2 & - & 3.6 & - & - & - & 4.9 & 3.2 & - & $\begin{array}{l}\cdots \\
-\end{array}$ & 3.1 \\
\hline
\end{tabular}

* 다자성양자를 제외한 순수다자만 해당되며, 다자성양자는 사업 유형에 맞게 분류

$\square$ 총 사업 목록

\begin{tabular}{|c|c|c|c|c|c|c|c|c|c|}
\hline & 세부사업명 & 내역사업명 & 사업 유형 & $\begin{array}{c}\text { 총사업예산 } \\
\text { (억원) }\end{array}$ & $\begin{array}{l}18 \text { 년 예산 } \\
\text { (억원) }\end{array}$ & $\begin{array}{l}\text { 신규/ } \\
\text { 계속 }\end{array}$ & $\begin{array}{l}\text { 총사업 } \\
\text { 기간 }\end{array}$ & \begin{tabular}{|c|} 
구분 \\
(양-다자)
\end{tabular} & $\begin{array}{l}\text { SDGS } \\
\text { 목표 }\end{array}$ \\
\hline 1 & $\begin{array}{l}\text { 산업통상협력개발지원 } \\
\text { 사업 }\end{array}$ & $\begin{array}{l}\text { 우즈베키스탄 섬유 테 } \\
\text { 크노파크 조성 }\end{array}$ & 프로젝트 & 189.40 & 59.40 & 계속 & $2015-2019$ & 양자무상 & 9 \\
\hline 2 & $\begin{array}{l}\begin{array}{l}\text { 산업통상협력개발지원 } \\
\text { 사업 }\end{array} \\
\end{array}$ & $\begin{array}{l}\text { 우즈베키스탄 농기계 } \\
\text { R\&D센터 조성 }\end{array}$ & 프로젝트 & 66.00 & 20.00 & 계속 & $2016-2019$ & 양자무상 & 9 \\
\hline 3 & $\begin{array}{l}\text { 산업통상협력개발지원 } \\
\text { 사업 }\end{array}$ & $\begin{array}{l}\text { 베트남 농기계 개량, } \\
\text { 시범보급 }\end{array}$ & 프로젝트 & 86.40 & 42.00 & 계속 & $2015-2018$ & 양자무상 & 9 \\
\hline 4 & $\begin{array}{l}\begin{array}{l}\text { 산업통상협력개발지원 } \\
\text { 사업 }\end{array} \\
\end{array}$ & \begin{tabular}{|l|} 
콜롬비아 수처리 테크 \\
노파크 조성 지원
\end{tabular} & 프로젝트 & 60.00 & 10.00 & 신규 & $2018-2021$ & 양자무상 & 9 \\
\hline 5 & $\begin{array}{l}\begin{array}{l}\text { 산업통상협력개발지원 } \\
\text { 사업 }\end{array} \\
\end{array}$ & \begin{tabular}{|l|} 
콜롬비아 하수처리 실 \\
증단지 구축
\end{tabular} & 프로젝트 & 70.00 & 20.00 & 신규 & $2018-2020$ & 양자무상 & 9 \\
\hline
\end{tabular}




\begin{tabular}{|c|c|c|c|c|c|c|c|c|c|}
\hline & 세부사업명 & 내역사업명 & 사업 유형 & $\begin{array}{l}\begin{array}{c}\text { 총사업예산 } \\
\text { (억원) }\end{array} \\
\end{array}$ & $\begin{array}{l}\text { '18년예산 } \\
\text { (억원) }\end{array}$ & $\begin{array}{l}\text { 신규/ } \\
\text { 계속 }\end{array}$ & $\begin{array}{l}\text { 총사업 } \\
\text { 기간 }\end{array}$ & $\begin{array}{c}\text { 구분 } \\
\text { (양.다자) } \\
\end{array}$ & $\begin{array}{l}\text { SDGs } \\
\text { 목표 }\end{array}$ \\
\hline & $\begin{array}{l}\text { 산업통상협력개발지원 } \\
\text { 사업 }\end{array}$ & $\begin{array}{l}\text { 에티오피아 섬유 테크 } \\
\text { 노파크 조성 지원 }\end{array}$ & 프로젝트 & 84.00 & 20.00 & 신규 & $2018-2022$ & 양자무상 & 9 \\
\hline & $\begin{array}{l}\begin{array}{l}\text { 산업통상협력개발지원 } \\
\text { 사업 }\end{array} \\
\end{array}$ & $\begin{array}{l}\text { 베트남 동나이성 하수 } \\
\text { 처리 플랜트 구축 }\end{array}$ & 프로젝트 & 60.00 & 25.00 & 신규 & $2018-2020$ & 양자무상 & 9 \\
\hline & $\begin{array}{l}\text { 산업통상협력개발지원 } \\
\text { 사업 }\end{array}$ & $\begin{array}{l}\text { 인도네시아 공작기계 } \\
\text { 테크니컬센터 설립 }\end{array}$ & 프로젝트 & 65.00 & 10.00 & 신규 & $2018-2020$ & 양자무상 & 9 \\
\hline & $\begin{array}{l}\begin{array}{l}\text { 산업통상협력개발지원 } \\
\text { 사업 }\end{array} \\
\end{array}$ & $\begin{array}{l}\text { 필리핀 금형 솔루션센 } \\
\text { 터 조성 }\end{array}$ & 프로젝트 & 50.00 & 10.00 & 신규 & $2018-2020$ & 양자무상 & 9 \\
\hline & $\begin{array}{l}\text { 산업통상협력개발지원 } \\
\text { 사업 }\end{array}$ & $\begin{array}{l}\text { 개도국 생산현장 애 } \\
\text { 로기술지도(미얀마) }\end{array}$ & 기타기술협력 & 4.70 & 3.50 & 계속 & $2017-2018$ & 양자무상 & 9 \\
\hline & $\begin{array}{l}\text { 산업통상협력개발지원 } \\
\text { 사업 }\end{array}$ & $\begin{array}{l}\text { 개도국 생산현장 애 } \\
\text { 로기술지도(이란) }\end{array}$ & 기타기술협력 & 4.80 & 3.50 & 계속 & $2017-2018$ & 양자무상 & 9 \\
\hline & $\begin{array}{l}\text { 산업통상협력개발지원 } \\
\text { 사업 }\end{array}$ & $\begin{array}{l}\text { 개도국 생산현장 애 } \\
\text { 로기술지도(필리핀) }\end{array}$ & 기타기술협력 & 5.00 & 2.50 & 신규 & $2018-2019$ & 양자무상 & 9 \\
\hline & 3 산업통상협력개발지원 & $\begin{array}{l}\text { 개도국 생산현장 애 } \\
\text { 로기술지도(라오스) }\end{array}$ & 기타기술협력 & 5.00 & 2.50 & 신규 & $2018-2019$ & 양자무상 & 9 \\
\hline & 4 산업통상협력개발지원 & $\begin{array}{l}\text { 개도국 생산현장 애 } \\
\text { 로기술지도(감보디아) }\end{array}$ & 기타기술협력 & 5.00 & 2.50 & 신규 & $2018-2019$ & 양자무상 & 9 \\
\hline & 산업통상협력개발지원 & $\begin{array}{l}\text { 개도국 생산현장 애 } \\
\text { 로기술지도(아제르바 } \\
\text { 이잔) }\end{array}$ & 기타기술협력 & 5.00 & 2.50 & 신규 & $2018-2019$ & 양자무상 & 9 \\
\hline & $\begin{array}{l}\text { 산업통상협력개발지원 } \\
\text { 사업 }\end{array}$ & $\begin{array}{l}\text { 개도국 생산현장 } \\
\text { 로개새룰지도(파라과이) }\end{array}$ & 기타기술협력 & 6.00 & 3.00 & 신규 & $2018-2019$ & 양자무상 & 9 \\
\hline & $\begin{array}{l}\text { 산업통상협력개발지원 } \\
\text { 사업 }\end{array}$ & $\begin{array}{l}\text { 개도국 생산현장 애 } \\
\text { 로기술지도(콜롬비아) }\end{array}$ & 협력 & 6.00 & 3.00 & 신규 & $2018-2019$ & 양자무상 & 9 \\
\hline & $\begin{array}{l}\text { 에너지산업협력개발지 } \\
\text { 원사업 }\end{array}$ & $\begin{array}{l}\text { 페루 스마트 배전망 } \\
\text { 구축 }\end{array}$ & 프로젝트 & 80.00 & 60.00 & 계속 & $2017-2019$ & 양자무상 & 7 \\
\hline & $\begin{array}{l}\text { 에너지산업협력개발지 } \\
\text { 원사업 }\end{array}$ & 필리핀 배전승압 지원 & 믈젝트 & 35.00 & 15.00 & 계속 & $2017-2018$ & 양자무상 & 7 \\
\hline & $\begin{array}{l}\text { 에너지산업협력개발지 } \\
\text { 원사업 }\end{array}$ & $\begin{array}{l}\text { 몽골 친환경 에너지타 } \\
\text { 운 조성지원 }\end{array}$ & 프로젝트 & 50.00 & 30.00 & 계속 & $2017-2018$ & 양자무상 & 7 \\
\hline & $\begin{array}{l}\text { 에너지산업협력개발지 } \\
\text { 원사업 }\end{array}$ & $\begin{array}{l}\text { 탄자니아 스마트 전력 } \\
\text { 수요관리 시스템 구 } \\
\text { 축 }\end{array}$ & E & .00 & .00 & 신규 & 2019 & 무상 & 7 \\
\hline 22 & $\begin{array}{l}\text { 에너지산업협력개발지 } \\
\text { 원사업 }\end{array}$ & $\begin{array}{l}\text { 에콰도르 마이크로그 } \\
\text { 리드 구축 }\end{array}$ & 프로제트 & 70.00 & 20.00 & 신규 & $2018-2020$ & 양자무상 & 7 \\
\hline 23 & $\begin{array}{l}\text { 에너지산업협력개발지 } \\
\text { 원사업 }\end{array}$ & $\begin{array}{l}\text { 라오스 수몰지역 이주 } \\
\text { 민 신재생에너지공급 } \\
\text { 친환경에너지타운 조 } \\
\text { 성 }\end{array}$ & 로젝트 & 37.41 & 30.97 & 신규 & $2018-2020$ & 양자무상 & 7 \\
\hline 24 & 전략국가기술협력사업 & $\begin{array}{l}\text { 개도국과의 적정기술 } \\
\text { 산업협력 }\end{array}$ & 민관협력 & & 8.00 & 신규 & $2017-2026$ & 양자무상 & 9 \\
\hline & $\begin{array}{l}\text { 한-개도국 협력사업 } \\
\text { 권역별 정책컬설팅 지 } \\
\text { 원사업(동남아시아) }\end{array}$ & \begin{tabular}{l|l|} 
권역별 정책컨설팅 \\
지원사업(인도네시아)
\end{tabular} & 개발컨설팅 & 7.84 & 1.96 & 신규 & $2017 \sim 2020$ & 양자무상 & 13 \\
\hline & $\begin{array}{l}\text { 한-개도국 협력사업 } \\
\text { 권역별 정책컨설팅 지 } \\
\text { 원사업(서남아시아) }\end{array}$ & $\begin{array}{l}\text { 권역별 정책컨설팅 } \\
\text { 지원사업(스리랑카) }\end{array}$ & 개발컨설팅 & 6.20 & 1.55 & 계속 & 2017 2020 & 양자무상 & 7 \\
\hline & $\begin{array}{l}\text { 한-개도국 협력사업 } \\
\text { 권역별 정책컬설팅 지 } \\
\text { 원사업(중앙아시아) }\end{array}$ & $\begin{array}{l}\text { 권역별 정책컨설팅 } \\
\text { 지원사업(우즈베키스 } \\
\text { 탄) }\end{array}$ & 개발컨설팅 & 6.20 & 1.55 & 계속 & 2017 2020 & 양자무상 & 13 \\
\hline & $\begin{array}{l}\text { 한-개도국 협력사업 } \\
3 \text { 권역별 정책컨설팅 지 } \\
\text { 원사업(중남미) }\end{array}$ & $\begin{array}{l}\text { 권역별 정책컨설팅 } \\
\text { 지원사업(페루) }\end{array}$ & 개발컨설팅 & 7.40 & 1.85 & 계속 & $2017 \sim 2020$ & 양자무상 & 13 \\
\hline & $\begin{array}{l}\text { 한-개도국 협력사업 } \\
\text { 국제기구협력사업(아 } \\
\text { 시아개발은행 협력) }\end{array}$ & $\begin{array}{l}\text { 국제기구협력사업 } \\
\text { (AsDB) }\end{array}$ & 프로젝트 & 8.40 & 2.00 & 신규 & 2018 2020 & 다자성양자 & 13 \\
\hline & $\begin{array}{l}\text { 한-개도국 협력사업 } \\
\text { 국제기구협력사업(아 } \\
\text { 시아에너지센터 협력) }\end{array}$ & $\begin{array}{l}\text { 국제기구협력사업 } \\
\text { (ASEAN) }\end{array}$ & 프로젝트 & 7.90 & 2.00 & 신규 & 2018 2020 & 다자성양자 & 13 \\
\hline
\end{tabular}




\begin{tabular}{|c|c|c|c|c|c|c|c|c|c|}
\hline & 세부사업명 & 내역사업명 & 사업 유형 & $\begin{array}{l}\text { 총사업 예산 } \\
\text { (억원) }\end{array}$ & $\begin{array}{l}\text { '18년예산 } \\
\text { (억원) }\end{array}$ & $\begin{array}{l}\text { 신규/ } \\
\text { 계속 }\end{array}$ & $\begin{array}{l}\text { 총사업 } \\
\text { 기간 }\end{array}$ & \begin{tabular}{|c|} 
구분 \\
(양-다자)
\end{tabular} & $\begin{array}{l}\text { SDGs } \\
\text { 목표 }\end{array}$ \\
\hline 31 & $\begin{array}{l}\text { 한-개도국 협력사업 } \\
\text { 국제기구협력사업(세 } \\
\text { 계은행_국제금융공사 } \\
\text { 협력) }\end{array}$ & $\begin{array}{l}\text { 국제기구협력사업 } \\
\text { (IFC) }\end{array}$ & 프로젝트 & 7.90 & 2.00 & 신규 & 2018 2020 & 다자성양자 & 13 \\
\hline 32 & $\begin{array}{l}\text { 한-개도국 협력사업 } \\
\text { 온실가스감축프로젝트 } \\
\text { 지원사업(개도국) }\end{array}$ & $\begin{array}{l}\text { 온실가스감축프로젝트 } \\
\text { 지원사업 }\end{array}$ & 민관협력 & 7.00 & 7.00 & 신규 & 2018 & 양자무상 & 13 \\
\hline 33 & $\begin{array}{l}\text { 개도국표준체계보급지 } \\
\text { 원사업 }\end{array}$ & $\begin{array}{l}\text { 캄보디아의 법정계량 } \\
\text { 및 제품안전제도 선 } \\
\text { 진화 지원 }\end{array}$ & 개발컨설팅 & 5.50 & 0.75 & 계속 & $2015-2019$ & 양자무상 & 8 \\
\hline 34 & $\begin{array}{l}\text { 개도국표준체계보급지 } \\
\text { 원사업 }\end{array}$ & $\begin{array}{l}\text { 라오스의 국가인정제 } \\
\text { 도 선진화 지원 }\end{array}$ & 개발컨설팅 & 5.50 & 0.75 & 계속 & $2015-2019$ & 양자무상 & 8 \\
\hline 35 & $\begin{array}{l}\text { 개도국표준체계보급지 } \\
\text { 원사업 }\end{array}$ & $\begin{array}{l}\text { 베트남의 법정계량 및 } \\
\text { 시험인증제도 선진화 } \\
\text { 지원 }\end{array}$ & 개발컨설팅 & 3.00 & 0.75 & 계속 & $2013-2019$ & 양자무상 & 8 \\
\hline 36 & $\begin{array}{l}\text { 개도국표준체계보급지 } \\
\text { 원사업 }\end{array}$ & $\begin{array}{l}\text { 미얀마의 국가표준인 } \\
\text { 증제도 선진화 지원 }\end{array}$ & 개발컨설팅 & 5.50 & 2.20 & 계속 & $2017-2021$ & 양자무상 & 8 \\
\hline 37 & $\begin{array}{l}\text { 개도국표준체계보급지 } \\
\text { 원사업 }\end{array}$ & $\begin{array}{l}\text { 페루의 법정계량 제도 } \\
\text { 및 제품안전 제도 전 } \\
\text { 수 }\end{array}$ & 개발컨설팅 & 7.00 & 1.50 & 계속 & $2016-2020$ & 양자무상 & 8 \\
\hline 38 & $\begin{array}{l}\text { 개도국표준체계보급지 } \\
\text { 원사업 }\end{array}$ & $\begin{array}{l}\text { 파라과이의 국가표준 } \\
\text { 인증제도 선진화 지 } \\
\text { 원 }\end{array}$ & 개발컨설팅 & 7.00 & 1.60 & 계속 & $2016-2020$ & 양자무상 & 8 \\
\hline 39 & $\begin{array}{l}\text { 개도국표준체계보급지 } \\
\text { 원사업 }\end{array}$ & $\begin{array}{l}\text { 키르기스스탄의 섬유 } \\
\text { 분야 시험·검사 및 } \\
\text { 제품안전제도 선진화 } \\
\text { 지원 }\end{array}$ & 개발컨설팅 & 5.50 & 2.60 & 신규 & $2018-2022$ & 양자무상 & 8 \\
\hline 40 & $\begin{array}{l}\text { 국제면화자문위원회 } \\
\text { 분담금 }\end{array}$ & $\begin{array}{l}\text { 국제자문면화위원회분 } \\
\text { 담금 } \\
\text { (ICAC) }\end{array}$ & & & 0.68 & 계속 & $1954-$ & 다자 & \\
\hline 41 & $\begin{array}{l}\text { 아시아생산성기구 분 } \\
\text { 담금 }\end{array}$ & $\begin{array}{l}\text { 아시아생산성기구분담 } \\
\text { 금 } \\
\text { (APO) }\end{array}$ & & & 13.69 & 계속 & $1961-$ & 다자 & \\
\hline 4 & $\begin{array}{l}\text { 한-개도국 국제기구 } \\
\text { 협력사업 }\end{array}$ & $\begin{array}{l}\text { 국제기구협력사업 } \\
\text { (IDB) }\end{array}$ & 프로젝트 & 6.00 & 2.00 & 신규 & $2018-2020$ & 다자성양자 & 13 \\
\hline
\end{tabular}




\section{보건복지부 2018년도 ODA 예산 계획[안]}

$\square$ 총괄

(단위: 억원)

\begin{tabular}{l|c|c|c||c|c|c}
\hline \multirow{2}{*}{ ODA 시행부처(기관) } & \multicolumn{3}{|c||}{2017} & \multicolumn{3}{c}{2018 (요구) } \\
\cline { 2 - 7 } & 양자 무상 & 다자 & 합계 & 양자 무상 & 다자 & 합계 \\
\hline 보건복지부 & 295.0 & 198.3 & 493.3 & 390.7 & 225.0 & 615.7 \\
\hline
\end{tabular}

※ 다자성양자는 양자에 포함

○ '18년도 ODA 시행목표

- 보건분야 SDGs 달성에 기여하여 개도국의 기본적 삶의 질 개선

- 특히, 보건의료분야에서 우리의 비교우위가 있는 모자보건 관련 국가 전략 목표 달성 지원, 보건의료서비스 전달체계 구축 지원, 건강보험정책 협력, 의료인력 중장기교육 등을 집중 추진

* SDGs 3.1 모성사망률 감소, 3.2 신생아 및 아동사망률 감소, 3.8 보편적 의료보장 달성에 기여, 3.c 개도국 보건의료 인력 개발 및 교육 확대

- 수원국 보건의료체계 강화 지원을 통해 자립역량 및 지속가능성 제고 노력 · 수원국 보건의료서비스 전달체계 개선에 기여

* 수원국과 공동으로 계획 · 수행 · 검토하는 체계룰 구축하여 수원국 보건전략 이행 지원

* 수원국 보건관계자의 역량을 강화하여 수원국 주인의식(Ownership) 제고

· 기지원사업 사후관리를 통해 상호책임성 및 지속가능성 증진 노력

- 협업기반 보건의료협력 사업 추진

- 국내 건강보험 및 질병관리 분야 전문기관과 협업을 강화하여 우리의 선진제도 전수 - 대학·연구기관 등과 협업하여 근거기반(evidence-based) 사업 수행 및 관리

우주요 정책과제

- 내실있는 ODA

- 한국형 $\mathrm{ODA}$ 보건분야 모델을 고려하여 재단 중점추진분야를 집중 지원

* 모자보건 증진, 보건의료체계 강화, 중장기 보건의료인력 교육훈련, 병원운영컨설팅, 건강보험 협력, 의료기기 관리운영체계 구축, 감염병 관리

- SDGs 목표 3 보건분야 달성에 기여하고 아동 - 여성 등 취약계층 중심의 보건의료서비스 이용률 제고

· ODA 평가·환류를 위한 자체평가 및 외부평가 강화

* 사업비 상위 5 개 사업 중 3 개 이상 사업에 대해 외부평가 실시 및 관련 예산 반영 예정

- 함께하는 ODA

- 유-무상 간 협의체 운영을 통해 효과적인 원조 수단을 도출, 상호 유기적으로 사업을 시행하며, 무-무상 간 협의체 상시운영을 통해 수원국 내 원조 조화 노력 지속

* (유상) EDCF: 보건의료 인프라+기자재지원, (무상) $\mathrm{KOFIH}$ : 운영자문 및 인적역량강화 
이기타(MOU 체결 현황)

\begin{tabular}{|c|c|c|c|c|}
\hline 연번 & 대상국가 & 대상 기관 & 기간 & 협약 내용 \\
\hline 1 & $\begin{array}{l}\text { 라오스 } \\
\text { (이종욱) }\end{array}$ & 보건부 & $' 15 \sim ' 18$ & $\begin{array}{l}\text { 탄자니아 도, 구 단위 병원 의공기사 역 } \\
\text { 량강화를 위한 교육훈련 및 의료기기 관리 } \\
\text { 체계 개선사업 지원 }\end{array}$ \\
\hline 2 & $\begin{array}{l}\text { 탄자니아 } \\
\text { (이종욱) }\end{array}$ & 보건부 & $' 15 \sim ' 18$ & $\begin{array}{l}\text { 라오스 중앙, 도 단위 병원 의공기사 역 } \\
\text { 량강화를 위한 교육훈련 및 의료기기 관리 } \\
\text { 체계 개선사업 지원 }\end{array}$ \\
\hline 3 & $\begin{array}{l}\text { 에티오피아 } \\
\text { (이종욱) }\end{array}$ & $\begin{array}{l}\text { 에 티 오 피 아 } \\
\text { St. Paul 병원 }\end{array}$ & ‘16 ’19 & 의료인력 역량강화 사업 지원 \\
\hline 4 & $\begin{array}{l}\text { 우간다 } \\
\text { (이종욱) }\end{array}$ & $\begin{array}{l}\text { 우간다 } \\
\text { 국립암센터 }\end{array}$ & $' 16 \sim ' 19$ & 암 진단 관리 역량강화 사업 지원 \\
\hline 5 & 캄보디아 & 보건부 & ‘17 ’21 & $\begin{array}{l}\text { 바탐방도 내 모자보건 서비스의 질, 이용 } \\
\text { 가능성 및 접근성 강화 지원, 교육자 수업 기 } \\
\text { 술 및 학생의 역량 강화 지원 협약 체결 } \\
\text { * 사업 협약 체결을 위한 문안 조정 중. } \\
\text { 협약 체결 예정(17.4월) }\end{array}$ \\
\hline 6 & 가나 & 보건부 & $' 13 \sim 18$ & 모자보건 및 건강보험제도 협력 지원 \\
\hline 7 & 에티오피아 & 재정경제부 & $' 14 \sim ’ 19$ & $\begin{array}{l}\text { 모자보건증진, 건강보험제도협력, 의료 } \\
\text { 기기 관리운영 체계 구축 지원 }\end{array}$ \\
\hline 8 & 미얀마 & 보건부 & $' 14 \sim ' 19$ & $\begin{array}{l}\text { 미얀마 일차보건의료체계 강화사업 지원 } \\
\text { 및 양 기관 역할 및 책임 명시 }\end{array}$ \\
\hline 9 & 라오스 & 보건부 & '16 '21 & $\begin{array}{l}\text { 라오스 보건의료체계 강화 사업 지원 } \\
\text { 및 양 기관 역할 명시 }\end{array}$ \\
\hline 10 & 탄자니아 & $\begin{array}{l}\text { 보건부 및 주 } \\
\text { 보건국 }\end{array}$ & ‘16 ’21 & $\begin{array}{l}\text { 지역보건의료체계강화를 통한 모자보건증 } \\
\text { 진 지원 }\end{array}$ \\
\hline 11 & 베트남 & 보건국 & $' 13 \sim ’ 21$ & $\begin{array}{l}\text { 종합병원 의료기기 사후관리 사업 세부 } \\
\text { 내용 및 양 기관 역할 명시 }\end{array}$ \\
\hline 12 & 탄자니아 & $\begin{array}{l}\text { 무힘빌리 } \\
\text { 의과대학 }\end{array}$ & $' 15 \sim ' 18$ & $\begin{array}{l}\text { 의과대학병원 개원 전·후 운영 컨설팅 및 } \\
\text { 의료인력 교육에 대한 지원 }\end{array}$ \\
\hline 13 & 모잠비크 & 보건부 & $' 15 \sim ' 18$ & $\begin{array}{l}\text { 켈리만 중앙 병원 개원 전·후 운영 컨설 } \\
\text { 팅 및 의료인력 교육에 대한 지원 }\end{array}$ \\
\hline 14 & $\begin{array}{l}\text { 우즈베키 } \\
\text { 스탄 }\end{array}$ & 보건부 & ‘14 '19 & $\begin{array}{l}\text { 국립아동병원 병원건립·운영 컨설팅 및 } \\
\text { 역량강화 사업을 위한 양 기관 역할 및 } \\
\text { 책임 명시 }\end{array}$ \\
\hline 15 & 몽골 & 보건부 & $' 16 \sim ' 19$ & $\begin{array}{l}\text { 몽골 국립진단치료센터 핵의학실 운영관 } \\
\text { 련 역량강화 및 컨설팅 지원 }\end{array}$ \\
\hline 16 & 스리랑카 & 보건국 & $' 15 \sim ’ 18$ & $\begin{array}{l}\text { 아비사웰라 지역병원 의료정보시스템 구 } \\
\text { 축 지원 }\end{array}$ \\
\hline 17 & 필리핀 & 보건부 & $' 11 \sim ' 16$ & 결핵 서비스 패키지 사업 지원 \\
\hline 18 & 우간다 & $\begin{array}{l}\text { 국립표준 } \\
\text { 실험실 }\end{array}$ & $' 16 \sim ' 19$ & 감염병 관리 체계 구축 지원 \\
\hline 19 & 케냐 & 의약품공급청 & $' 16$ '19 & 의약품 공급체계 개선 지원 \\
\hline
\end{tabular}


(억원, \%)

\begin{tabular}{|c|c|c|c|c|c|c|c|c|c|c|c|c|}
\hline \multirow[b]{2}{*}{ 구분 } & \multirow[b]{2}{*}{ 계 } & \multirow[b]{2}{*}{$\begin{array}{l}\text { 프로 } \\
\text { 젝트 }\end{array}$} & \multirow[b]{2}{*}{$\begin{array}{l}\text { 프로 } \\
\text { 르램 }\end{array}$} & \multirow[b]{2}{*}{$\begin{array}{l}\text { 개발 } \\
\text { 컨설팅 }\end{array}$} & \multicolumn{4}{|c|}{ 기술협력 } & \multirow{2}{*}{$\begin{array}{c}\text { 민관 } \\
\text { 협력 } \\
\text { (NGO, } \\
\text { 기업) }\end{array}$} & \multirow[b]{2}{*}{$\begin{array}{l}\text { 행정 } \\
\text { 비용 }\end{array}$} & \multirow[b]{2}{*}{ 기타 } & \multirow[b]{2}{*}{$\begin{array}{l}\text { 순수 } \\
\text { 다자* }\end{array}$} \\
\hline & & & & & $\begin{array}{l}\text { 연수 } \\
\text { 사업 }\end{array}$ & $\begin{array}{l}\text { 장항 } \\
\text { 지원 }\end{array}$ & $\begin{array}{l}\text { 봉사단 } \\
\text { 파견 }\end{array}$ & $\begin{array}{l}\text { 기타 } \\
\text { 기술 } \\
\text { 협력 }\end{array}$ & & & & \\
\hline \multirow{2}{*}{ '17년 } & 493.3 & 176.4 & 20.9 & 6.0 & 50.5 & - & - & 3.8 & 0.9 & 27.1 & 9.5 & 198.3 \\
\hline & 100 & 35.8 & 4.2 & 1.2 & 10.2 & - & - & 0.8 & 0.2 & 5.5 & 1.9 & 40.2 \\
\hline '18년 & 615.7 & 239.3 & - & - & 62.3 & - & - & - & 0.9 & 25.8 & 62.3 & 225.0 \\
\hline (요구) & 100 & 38.9 & - & - & 10.0 & - & - & - & 0.1 & 4.2 & 10.1 & 36.5 \\
\hline
\end{tabular}

* 다자성양자를 제외한 순수다자만 해당되며, 다자성양자는 사업 유형에 맞게 분류

\section{$\square$ 총 사업 목록}

\begin{tabular}{|c|c|c|c|c|c|c|c|c|c|}
\hline & 세부사업명 & 내역사업명 & 사업 유형 & $\begin{array}{c}\text { 총사업예산 } \\
\text { (억원) }\end{array}$ & $\begin{array}{l}\text { '18년예산 } \\
\text { (억원) }\end{array}$ & \begin{tabular}{|l|} 
신규/ \\
계속
\end{tabular} & $\begin{array}{l}\text { 총사업 } \\
\text { 기간 }\end{array}$ & $\begin{array}{c}\text { 구분 } \\
\text { (양-다자) }\end{array}$ & $\begin{array}{l}\text { SDGs } \\
\text { 목표 }\end{array}$ \\
\hline 1 & 개도국개발협력사업 & $\begin{array}{l}\text { 이종욱펠로우십 프로 } \\
\text { 그램 }\end{array}$ & 연수사업 & 58.56 & 58.56 & 계속 & 11 계속 & 양자무상 & 3 \\
\hline 2 & 개도국개발협력사업 & $\begin{array}{l}\text { 캄보디아 통합모자보 } \\
\text { 건증진사업 }\end{array}$ & 프로젝트 & 128.60 & 23.00 & 계속 & $17 \sim 21$ & 양자무상 & 3 \\
\hline 3 & 개도국개발협력사업 & $\begin{array}{l}\text { 가나 모자보건증진 및 } \\
\text { 건강보험제도 개선 협 } \\
\text { 력사업 }\end{array}$ & 프로젝트 & 75.00 & 17.20 & 계속 & $13 \sim 18$ & 양자무상 & 3 \\
\hline 4 & 개도국개발 & $\begin{array}{l}\text { 에티오피아 모자보건 } \\
\text { 증진 및 건강보험제 } \\
\text { 도 협력사업 }\end{array}$ & 프로젝트 & 76.73 & 16.80 & 계속 & $14 \sim 19$ & 양자무상 & 3 \\
\hline 5 & 개도국개발협력사업 & $\begin{array}{l}\text { 미얀마 1차보건의료 } \\
\text { 체계 강화사업 }\end{array}$ & 프로젝트 & 67.90 & 12.00 & 계속 & $14 \sim 19$ & 양자무상 & 3 \\
\hline 6 & 개도국개 & $\begin{array}{l}\text { 라오스 보건의료체계 } \\
\text { 강화사업 }\end{array}$ & 프로젝트 & 148.00 & 23.00 & 계속 & $16 \sim 21$ & 양자무상 & 3 \\
\hline 7 & 개도국개발협력사업 & $\begin{array}{l}\text { 탄자니아 지역보건의 } \\
\text { 료체계 강화사업 }\end{array}$ & 프로젝트 & 59.44 & 10.00 & 계속 & $16 \sim 21$ & 양자무상 & 3 \\
\hline 8 & $\begin{array}{l}\text { 개도국개발협력사업 } \\
\text { (ODA) }\end{array}$ & $\begin{array}{l}\text { 베트남 의료시설 건립 } \\
\text { 운영 유무상연계사업 }\end{array}$ & 프로젝트 & 39.35 & 3.50 & 계속 & $2013-2021$ & 양자무상 & 3 \\
\hline 9 & 개도국개블 & $\begin{array}{l}\text { 탄자니아 의료시설건 } \\
\text { 敦운영 유무상 연계 } \\
\text { 사업 }\end{array}$ & 프로젝트 & 20.70 & 3.00 & 계속 & $13 \sim 19$ & 양자무상 & 3 \\
\hline 10 & 개도국가 & 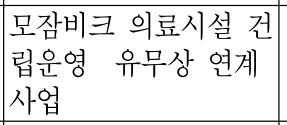 & 프로젝트 & 18.50 & 3.00 & 계속 & $13 \sim 19$ & 양자무상 & 3 \\
\hline 11 & 개도국개발협력사업 & $\begin{array}{l}\text { 우즈베키스탄 의료시 } \\
\text { 설 건립운영 유무상 } \\
\text { 연계사업 }\end{array}$ & 프로젝트 & 47.00 & 8.00 & 계속 & $2014-2019$ & 양자무상 & 3 \\
\hline 12 & 개도국가 & $\begin{array}{l}\text { 몽골 의료시설 건립운 } \\
\text { 영 유무상 연계사업 }\end{array}$ & 프로젝트 & 12.60 & 3.00 & 계속 & $15 \sim 19$ & 양자무상 & 3 \\
\hline 13 & 개도국 & $\begin{array}{l}\text { 에티오피아 의료기기 } \\
\text { 관리운영체계 구축사 } \\
\text { 업 }\end{array}$ & 프로젝트 & 53.00 & 9.00 & 계속 & $15 \sim 20$ & 양자무상 & 3 \\
\hline 14 & 개도국개발협력사업 & $\begin{array}{l}\text { 신규사업개발연구및타 } \\
\text { 당성조사사업 }\end{array}$ & 행정비용 & 1.60 & 1.60 & 신규 & 2018 & 양자무상 & 3 \\
\hline 15 & 개도국개발협력사업 & $\begin{array}{l}\text { 기지원사업 사후관리 } \\
\text { 및 지속가능성 제고 } \\
\text { 사업 (스리랑카) }\end{array}$ & 프로젝트 & 6.29 & 1.14 & 계속 & $14 \sim 18$ & 양자무상 & 3 \\
\hline 16 & 개도국개발협력사업 & $\begin{array}{l}\text { 기지원사업 사후관리 } \\
\text { 哭 지속가능성 제고 } \\
\text { 사업 (필리핀) }\end{array}$ & 프로젝트 & 3.03 & 1.20 & 계속 & $17 \sim 19$ & 양자무상 & 3 \\
\hline 17 & 개도국개발협력사업 & $\begin{array}{l}\text { 우간다 국가 감염병관 } \\
\text { 리 역량강화 사업 }\end{array}$ & 프로젝트 & 15.00 & 3.00 & 계속 & $17 \sim 21$ & 양자무상 & 3 \\
\hline
\end{tabular}




\begin{tabular}{|c|c|c|c|c|c|c|c|c|c|}
\hline & 세부사업명 & 내역사업명 & 사업 유형 & $\begin{array}{l}\begin{array}{c}\text { 총사업 예산 } \\
\text { (억원) }\end{array} \\
\end{array}$ & $\begin{array}{l}18 \text { 년예산 } \\
\text { (억원) }\end{array}$ & $\begin{array}{l}\text { 신규/ } \\
\text { 계속 }\end{array}$ & $\begin{array}{l}\text { 총사업 } \\
\text { 기간 }\end{array}$ & \begin{tabular}{|c|} 
구분 \\
(양-다자)
\end{tabular} & $\begin{array}{l}\text { SDGS } \\
\text { 목표 }\end{array}$ \\
\hline 18 & 개도국개발협력사업 & $\begin{array}{l}\text { 케냐 지역사회 건강증 } \\
\text { 진 및 건강보험 정책 } \\
\text { 협력사업 }\end{array}$ & 프로젝트 & 11.00 & 3.00 & 계속 & $17 \sim 19$ & 양자무상 & 3 \\
\hline 19 & 개도국개발협력사업 & $\begin{array}{l}\text { 우간다 지역사회 건강 } \\
\text { 증진사업 }\end{array}$ & 프로젝트 & 43.27 & 8.00 & 계속 & $17 \sim 21$ & 양자무상 & 3 \\
\hline 20 & 개도국개발협력사업 & $\begin{array}{l}\text { 라오스 감염병관리 역 } \\
\text { 량강화 사업 }\end{array}$ & 프로젝트 & 12.00 & 3.00 & 신규 & $18 \sim 21$ & 양자무상 & 3 \\
\hline 21 & 개도국개발협력사업 & $\begin{array}{l}\text { 라오스 의료기기 관리 } \\
\text { 운영 체계구축 }\end{array}$ & 프로젝트 & 50.00 & 8.00 & 신규 & $18 \sim 22$ & 양자무상 & 3 \\
\hline 22 & 개도국개발협력사업 & ODA 운영비 & 행정비용 & 24.24 & 24.24 & 계속 & & 양자무상 & \\
\hline 23 & $\begin{array}{l}\text { 사회복지정책수립 및 } \\
\text { 관리활동 }\end{array}$ & $\begin{array}{l}\text { 사회복지 국제교류 } \\
\text { 및 협력지원(에티오피 } \\
\text { 아) }\end{array}$ & 연수사업 & 3.75 & 0.94 & 계속 & $17 \sim 20$ & 양자무상 & 10 \\
\hline 24 & $\begin{array}{l}\text { 사회복지정책수립 및 } \\
\text { 관리활동 }\end{array}$ & $\begin{array}{l}\text { 사회복지 국제교류 및 } \\
\text { 협력지원(우간다) }\end{array}$ & 연수사업 & 3.75 & 0.94 & 계속 & $17 \sim 20$ & 양자무상 & 10 \\
\hline 25 & $\begin{array}{l}\text { 사회복지정책수립 및 } \\
\text { 관리활동 }\end{array}$ & $\begin{array}{l}\text { 사회복지 국제교류 및 } \\
\text { 협력지원(몽골) }\end{array}$ & 연수사업 & 3.75 & 0.94 & 계속 & $17 \sim 20$ & 양자무상 & 10 \\
\hline 26 & $\begin{array}{l}\text { 사회복지정책수립 및 } \\
\text { 관리활동 }\end{array}$ & $\begin{array}{l}\text { 사회복지 국제교류 및 } \\
\text { 협력지원(라오스) }\end{array}$ & 연수사업 & 3.75 & 0.94 & 신규 & $18 \sim 21$ & 양자무상 & 10 \\
\hline 27 & $\begin{array}{l}\text { WHO 사업분담금 지 } \\
\text { 원 }\end{array}$ & $\begin{array}{l}\text { WHO 사업분담금 지 } \\
\text { 원 }\end{array}$ & 프로젝트 & & 22.73 & 계속 & 2012 & 다자성양자 & 3 \\
\hline 28 & $\begin{array}{l}\text { WPRO 전략사업 추 } \\
\text { 진 }\end{array}$ & WPRO 전략사업 추진 & 프로젝트 & & 26.74 & 계속 & $2007 \sim$ & 다자성양자 & 3 \\
\hline 29 & $\begin{array}{l}\text { WHO전통의약활성화 } \\
\text { 지원 }\end{array}$ & $\begin{array}{l}\text { WHO전통의약활성화 } \\
\text { 지원 }\end{array}$ & 프로젝트 & & 6.00 & 계속 & $2010 \sim$ & 다자성양자 & 3 \\
\hline 30 & 감염병관리국제부담금 & 감염병관리국제부담금 & 프로젝트 & & 25.00 & 계속 & $2006 \sim$ & 다자성양자 & 3 \\
\hline 31 & 인구개발국제부담금 & $\begin{array}{l}\text { 국제인구보건복지연맹 } \\
\text { 분담금 }\end{array}$ & 민관협력 & & 0.91 & 계속 & $1974 \sim$ & 다자성양자 & 3 \\
\hline 32 & $\begin{array}{l}\text { 국제적십자위원회분담 } \\
\text { 금(ODA) }\end{array}$ & $\begin{array}{l}\text { 국제적십자위원회분담 } \\
\text { 금 }\end{array}$ & & & 3.54 & 계속 & 2006-계속 & 다자 & \\
\hline 33 & $\begin{array}{l}\text { WHO 의무분담금 납 } \\
\text { 부 }\end{array}$ & $\begin{array}{l}\text { WHO 의무분담금 납 } \\
\text { 부 }\end{array}$ & & & 85.52 & 계속 & 2006-계속 & 다자 & \\
\hline 34 & $\begin{array}{l}\text { 국제암연구소 분담금 } \\
\text { 납부(ODA) }\end{array}$ & 국제암연구소 분담금 & 기타 & & 9.48 & 계속 & 2006 & 다자성양자 & \\
\hline 35 & $\begin{array}{l}\text { 세계보건기구 담배규 } \\
\text { 제기본협약 분담금 }\end{array}$ & $\begin{array}{l}\text { 세계보건기구 담배규 } \\
\text { 제기본협약 분담금 }\end{array}$ & 기타 & & 2.83 & 계속 & $2007 \sim$ & 다자성양자 & 3 \\
\hline 36 & 인구개발국제부담금 & $\begin{array}{l}\text { 유엔인구활동기금 분 } \\
\text { 담금 }\end{array}$ & & & 1.16 & 계속 & $1974 \sim$ & 다자 & \\
\hline 37 & 글로벌펀드 기여금 & 글로벌펀드 기여금 & & & 20.54 & 계속 & 2004-계속 & 다자 & \\
\hline 38 & 국제백신연구소지원 & 국제백신연구소지원 & & & 114.26 & 계속 & 1995-계속 & 다자 & \\
\hline 39 & 국제백 & \begin{tabular}{|l|} 
글로벌헬스기술연구기 \\
금 설립
\end{tabular} & 기타 & 261.63 & 50.00 & 신규 & $2018-2022$ & 다자성양자 & 3 \\
\hline
\end{tabular}


$\square$ 총괄

(단위: 억원)

\begin{tabular}{l|c|c|c||c|c|c}
\hline \multirow{2}{*}{ ODA 시행부처(기관) } & \multicolumn{3}{|c||}{2017} & \multicolumn{3}{c}{2018 (요구) } \\
\cline { 2 - 7 } & 양자 무상 & 다자 & 합계 & 양자 무상 & 다자 & 합계 \\
\hline 환경부 & 67.2 & 43.3 & 110.6 & 87.7 & 38 & 125.7 \\
\hline
\end{tabular}

※ 다자성양자는 양자에 포함

○ '18년도 ODA 시행목표

- SDG의 방향에 부합하도록 환경 분야 신규사업 발굴 및 지원 확대 추진

우주요 정책과제

- 환경개선 마스터플랜, 서울이니셔티브 등 개도국의 환경정책 개선에 기여하여 개도국 삶의 질 향상 도모

- 주요 국제기구 분담금 납부를 통해 책임 있는 국제사회 일원으로 활동

$\square$ 유형별 분류

(억원, \%)

\begin{tabular}{|c|c|c|c|c|c|c|c|c|c|c|c|c|}
\hline \multirow[b]{2}{*}{ 구분 } & \multirow[b]{2}{*}{ 계 } & \multirow[b]{2}{*}{$\begin{array}{l}\text { 프로 } \\
\text { 젝트 }\end{array}$} & \multirow[b]{2}{*}{$\begin{array}{l}\text { 프로 } \\
\text { 르램 }\end{array}$} & \multirow[b]{2}{*}{$\begin{array}{l}\text { 개발 } \\
\text { 컨설팅 }\end{array}$} & \multicolumn{4}{|c|}{ 기술협력 } & \multirow{2}{*}{$\begin{array}{c}\text { 민관 } \\
\text { 협력 } \\
\text { (NGO, } \\
\text { 기업) }\end{array}$} & \multirow[b]{2}{*}{$\begin{array}{l}\text { 행정 } \\
\text { 비용 }\end{array}$} & \multirow[b]{2}{*}{ 기타 } & \multirow[b]{2}{*}{$\begin{array}{l}\text { 순수 } \\
\text { 다자* }\end{array}$} \\
\hline & & & & & $\begin{array}{l}\text { 연수 } \\
\text { 사업 }\end{array}$ & $\begin{array}{l}\text { 장항 } \\
\text { 지원 }\end{array}$ & $\begin{array}{l}\text { 봉사단 } \\
\text { 파견 }\end{array}$ & $\begin{array}{l}\text { 기타 } \\
\text { 기술 } \\
\text { 협력 }\end{array}$ & & & & \\
\hline \multirow{2}{*}{ '17년 } & 110.6 & 28.5 & - & 20.2 & 2.0 & - & - & 16.5 & - & - & - & 43.3 \\
\hline & 100 & 25.8 & - & 18.3 & 1.8 & - & - & 14.9 & - & - & - & 39.2 \\
\hline \multirow{2}{*}{$\begin{array}{c}\text { '18년 } \\
(\text { 요구) }\end{array}$} & 125.7 & 33.1 & - & 29.2 & 2.0 & - & - & 16.2 & - & - & 7.2 & 38 \\
\hline & 100 & 26.3 & - & 23.2 & 1.6 & - & - & 12.9 & - & - & 5.7 & 30.3 \\
\hline
\end{tabular}

* 다자성양자를 제외한 순수다자만 해당되며, 다자성양자는 사업 유형에 맞게 분류

$\square$ 총 사업 목록

\begin{tabular}{|c|c|c|c|c|c|c|c|c|c|}
\hline & 세부사업명 & 내역사업명 & 사업 유형 & $\begin{array}{l}\text { 총사업예산 } \\
\text { (억원) }\end{array}$ & $\begin{array}{l}\text { '18년예산 } \\
\text { (억원) }\end{array}$ & $\begin{array}{l}\text { 신규/ } \\
\text { 계속 }\end{array}$ & $\begin{array}{l}\text { 총사업 } \\
\text { 기간 }\end{array}$ & $\begin{array}{c}\text { 구분 } \\
\text { (양-다자) }\end{array}$ & $\begin{array}{l}\text { SDGs } \\
\text { 목표 }\end{array}$ \\
\hline 1 & $\begin{array}{l}\text { 환경산업수출기반육성 } \\
\text { 지원 }\end{array}$ & $\begin{array}{l}\text { 개도국 환경개선마스 } \\
\text { 터플랜 수립지원사업 } \\
\text { (에티오피아) }\end{array}$ & 개발컨설팅 & 9.00 & 9.00 & 신규 & 2018 & 양자무상 & 6 \\
\hline 2 & $\begin{array}{l}\text { 환경산업수출기반육성 } \\
\text { 지원 }\end{array}$ & $\begin{array}{l}\text { 개도국 환경개선마스 } \\
\text { 터플랜 수립지원사업 } \\
\text { (인도네시아) }\end{array}$ & 개발컨설팅 & 9.00 & 9.00 & 신규 & 14 개월 & 양자무상 & 6 \\
\hline 3 & $\begin{array}{l}\text { 환경산업수출기반육성 } \\
\text { 지원 }\end{array}$ & $\begin{array}{l}\text { 개도국 환경개선마스 } \\
\text { 터플랜 수립지원사업 } \\
\text { (베트남) }\end{array}$ & 개발컨설팅 & 9.00 & 9.00 & 신규 & 2018 2019 & 양자무상 & 3 \\
\hline 4 & $\begin{array}{l}\text { 확경산업수출기반육성 } \\
\text { 지원 }\end{array}$ & $\begin{array}{l}\text { 해외환경기술인력 초 } \\
\text { 청연수 }\end{array}$ & 연수사업 & 2.00 & 2.00 & 신규 & $2018 \sim 2025$ & 양자무상 & 4 \\
\hline 5 & 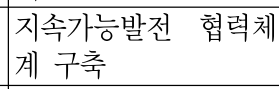 & $\begin{array}{l}\text { 서울이니셔티브 네트 } \\
\text { 워크 사업(필리핀) }\end{array}$ & 개발컨설팅 & 1.10 & 1.10 & 신규 & 2018 & 양자무상 & 13 \\
\hline 6 & $\begin{array}{l}\text { 지속가능발전 협력체 } \\
\text { 계 구축 }\end{array}$ & $\begin{array}{l}\text { 태평양 도서국 농촌지 } \\
\text { 역의 소규모 하수도 } \\
\text { 보급사업(피지) }\end{array}$ & 프로젝트 & 5.50 & 5.50 & 신규 & 2018 & 양자무상 & 6 \\
\hline
\end{tabular}




\begin{tabular}{|c|c|c|c|c|c|c|c|c|c|}
\hline & 세부사업명 & 내역사업명 & 사업 유형 & $\begin{array}{c}\begin{array}{c}\text { 총사업 예산 } \\
\text { (억원) }\end{array} \\
\end{array}$ & $\begin{array}{l}\text { '18년 예산 } \\
\text { (억원) }\end{array}$ & \begin{tabular}{|l|} 
신규/ \\
계속 \\
\end{tabular} & $\begin{array}{l}\text { 총사업 } \\
\text { 기간 }\end{array}$ & $\begin{array}{c}\text { 구분 } \\
\text { (양-다자) }\end{array}$ & $\begin{array}{l}\text { SDGS } \\
\text { 목표 }\end{array}$ \\
\hline 7 & $\begin{array}{l}\mathrm{UN} \text { 지속가능발전센 } \\
\text { 터 부담금 }\end{array}$ & $\begin{array}{l}\text { UN 지속가능발전센터 } \\
\text { 부담금 }\end{array}$ & 기타기술협력 & 94.40 & 16.18 & 계속 & $2011-2018$ & 다자성양자 & 17 \\
\hline 8 & 환경보건 기반 강화 & $\begin{array}{l}\text { WHO 환경보건 국제 } \\
\text { 분담금 }\end{array}$ & 프로젝트 & & 3.00 & 신규 & 2018 계속 & 다자성양자 & 3 \\
\hline 9 & $\begin{array}{l}\text { 한-UNEP 녹색경제 } \\
\text { 이행지원사업 }\end{array}$ & $\begin{array}{l}\text { 한-UNEP 녹색경제 } \\
\text { 이행지원사업 }\end{array}$ & 프로젝트 & & 9.30 & 계속 & $2013 \sim 2020$ & 다자성양자 & 8 \\
\hline 10 & 자연보전 국제협력 & 습지보호지역 분담금 & 프로젝트 & & 5.30 & 계속 & 1997-계속 & 다자성양자 & 15 \\
\hline 11 & 국제환경협력 분담금 & UNEP 분담금 & & & 7.44 & 계속 & 1983-계속 & 다자 & \\
\hline 12 & 국제환경협력 분담금 & UNESCAP 분담금 & 기타 & & 1.11 & 계속 & 2006-계속 & 다자성양자 & 17 \\
\hline 13 & 국제환경협력 분담금 & 기후변화협약 분담금 & & & 7.50 & 계속 & 1995-계속 & 다자 & \\
\hline 14 & 4지구환경금융 부담금 & 지구환경금융 부담금 & & 85.43 & 23.18 & 계속 & 1995-계속 & 다자 & \\
\hline 15 & 5 자연보전 국제협력 & IUCN 국가회원 회비 & 기타 & & 3.46 & 계속 & 2006-계속 & 다자성양자 & 15 \\
\hline 16 & 5자연보전 국제협력 & $\begin{array}{l}\text { IUCN 프레임워크 파 } \\
\text { 트너십 }\end{array}$ & 프로젝트 & & 10.00 & 신규 & $2018-2020$ & 다자성양자 & 15 \\
\hline 17 & 7자연보전 국제협력 & $\begin{array}{l}\text { 멸종위기 동식물 협약 } \\
\text { 분담금 }\end{array}$ & 기타 & & 1.42 & 계속 & 1993-계속 & 다자성양자 & 15 \\
\hline 18 & 3바젤협약 분담금 & 바젤협약 분담금 & 기타 & & 1.38 & 계속 & 2006-계속 & 다자성양자 & 3 \\
\hline
\end{tabular}




\section{고용노동부 2018년도 ODA 예산 계획[안]}

$\square$ 총괄

(단위: 억원)

\begin{tabular}{l|c|c|c||c|c|c}
\hline \multirow{2}{*}{$\mathrm{ODA}$ 시행부처(기관) } & \multicolumn{3}{|c||}{2017} & \multicolumn{3}{c}{2018 (요구) } \\
\cline { 2 - 7 } & 양자 무상 & 다자 & 합계 & 양자 무상 & 다자 & 합계 \\
\hline 고용노동부 & 19.9 & 54.7 & 74.5 & 58.9 & 54.7 & 113.6 \\
\hline
\end{tabular}

※ 다자성양자는 양자에 포함

○ '18년도 ODA 시행목표

- 고용정책, 노동시장, 직업훈련 등 개도국 고용노동분야 제도 구축 지원을 통해 $\mathrm{SDG} 8$ (지속적, 포괄적 경제성장 및 생산적 완전고용 및 양질의 일자리 창출) 실현에 기여

- 우리 기업 진출국 등 기술인력 양성, 작업환경(산업안전) 개선 및 노사관계 지원을 통해 중점협력국 사회 발전 및 양국간 경제교류 활성화에 기여

으주요 정책과제

- 개도국 노동시장, 직업훈련, 산업안전, 고용서비스 등 고용노동분야 정책컨 설팅·세미나·교류협력을 통해 우리나라 발전경험 전수

\section{유형별 분류}

(억원, \%)

\begin{tabular}{|c|c|c|c|c|c|c|c|c|c|c|c|c|}
\hline \multirow[b]{2}{*}{ 구분 } & \multirow[b]{2}{*}{ 계 } & \multirow[b]{2}{*}{ 프로 } & \multirow[b]{2}{*}{$\begin{array}{l}\text { 프로 } \\
\text { 그램 }\end{array}$} & \multirow[b]{2}{*}{$\begin{array}{l}\text { 개발 } \\
\text { 컨설팅 }\end{array}$} & \multicolumn{4}{|c|}{ 기술협력 } & \multirow{2}{*}{$\begin{array}{c}\text { 민관 } \\
\text { 협력 } \\
\text { (NGO, } \\
\text { 기업) }\end{array}$} & \multirow[b]{2}{*}{$\begin{array}{l}\text { 행정 } \\
\text { 비용 }\end{array}$} & \multirow[b]{2}{*}{ 기타 } & \multirow[b]{2}{*}{$\begin{array}{l}\text { 순수 } \\
\text { 다자* }\end{array}$} \\
\hline & & & & & $\begin{array}{l}\text { 연수 } \\
\text { 사업 }\end{array}$ & $\begin{array}{l}\text { 장학 } \\
\text { 지원 }\end{array}$ & $\begin{array}{l}\text { 봉사단 } \\
\text { 파견 }\end{array}$ & $\begin{array}{l}\text { 기타 } \\
\text { 기술 } \\
\text { 협력 }\end{array}$ & & & & \\
\hline \multirow{2}{*}{ '17년 } & 74.5 & 2.0 & - & 3.4 & 2.4 & - & - & 12.0 & - & - & - & 54.7 \\
\hline & 100 & 2.7 & - & 4.6 & 3.2 & - & 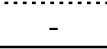 & 16.2 & - & - & - & 73.4 \\
\hline '18년 & 113.6 & 32.0 & - & - & 14.2 & - & - & 12.7 & - & - & - & 54.7 \\
\hline (요구) & 100 & 28.2 & - & $\cdots$ & 12.5 & - & $\begin{array}{l}\cdots \\
-\end{array}$ & 11.2 & $\begin{array}{l}\cdots \\
-\end{array}$ & - & - & 48.1 \\
\hline
\end{tabular}

* 다자성양자를 제외한 순수다자만 해당되며, 다자성양자는 사업 유형에 맞게 분류

$\square$ 총 사업 목록

\begin{tabular}{|c|c|c|c|c|c|c|c|c|c|}
\hline & 세부사업명 & 내역사업명 & 사업 유형 & $\begin{array}{l}\text { 총사업 예산 } \\
\text { (억원) }\end{array}$ & $\begin{array}{l}\text { '18년예산 } \\
\text { (억원) }\end{array}$ & $\begin{array}{l}\text { 신규/ } \\
\text { 계속 }\end{array}$ & $\begin{array}{l}\text { 총사업 } \\
\text { 기간 }\end{array}$ & $\begin{array}{c}\text { 구분 } \\
\text { (양-다자) }\end{array}$ & $\begin{array}{l}\text { SDGs } \\
\text { 목표 }\end{array}$ \\
\hline 1 & $\begin{array}{l}\text { 개도국 고용노동분야 } \\
\text { 개발협력(ODA) }\end{array}$ & $\begin{array}{l}\text { 개도국 고용노동분야 } \\
\text { 제도구축 지원(라오 } \\
\text { 스) }\end{array}$ & 연수사업 & 4.20 & 1.40 & 신규 & $\begin{array}{c}\text { 2018년 20 } \\
\text { 20년 }\end{array}$ & 양자무상 & 8 \\
\hline 2 & $\begin{array}{l}\text { 개도국 고용노동분야 } \\
\text { 개발협력(ODA) }\end{array}$ & $\begin{array}{l}\text { 개도국 고용노동분야 } \\
\text { 제도구축 지원(스리 } \\
\text { 랑카) }\end{array}$ & 연수사업 & 4.20 & 1.40 & 신규 & $\begin{array}{c}\text { 2018년 20 } \\
\text { 20년 }\end{array}$ & 양자무상 & 8 \\
\hline 3 & $\begin{array}{l}\text { 개도국 고용노동분야 } \\
\text { 개발협력(ODA) }\end{array}$ & $\begin{array}{l}\text { 개도국 고용노동분야 } \\
\text { 제도구축 지원(페루) }\end{array}$ & 연수사업 & 4.20 & 1.40 & 신규 & $\begin{array}{c}\text { 2018년 20 } \\
\text { 20년 }\end{array}$ & 양자무상 & 8 \\
\hline 4 & $\begin{array}{l}\text { 개도국 고용노동분야 } \\
\text { 개발협력(ODA) }\end{array}$ & $\begin{array}{l}\text { 한-ASEAN 고용노동 } \\
\text { 정책교류 }\end{array}$ & 기타기술협력 & 0.80 & 0.80 & 신규 & 2018년 & 양자무상 & 8 \\
\hline
\end{tabular}




\begin{tabular}{|c|c|c|c|c|c|c|c|c|c|}
\hline & 세부사업명 & 내역사업명 & 사업 유형 & $\begin{array}{l}\begin{array}{l}\text { 총사업 예산 } \\
\text { (억원) }\end{array} \\
\end{array}$ & $\begin{array}{l}18 \text { 년예산 } \\
\text { (억원) }\end{array}$ & \begin{tabular}{|l} 
신규/ \\
계속
\end{tabular} & $\begin{array}{l}\text { 총사업 } \\
\text { 기간 }\end{array}$ & \begin{tabular}{|c|} 
구분 \\
(양-다자) \\
\end{tabular} & $\begin{array}{l}\text { SDGs } \\
\text { 목표 }\end{array}$ \\
\hline 5 & $\begin{array}{l}\text { 개도국 고용노동분야 } \\
\text { 개발협력(ODA) }\end{array}$ & $\begin{array}{l}\text { 다자금융기구(IDB } \\
\text { 등)를 통한 개도국 } \\
\text { 역량강화 }\end{array}$ & 기타기술협력 & 0.93 & 0.93 & 신규 & 2018년 & 양자무상 & 8 \\
\hline 6 & $\begin{array}{l}\text { 개도국 고용노동분야 } \\
\text { 개발협력(ODA) }\end{array}$ & $\begin{array}{l}\text { 개도국 고용서비스 } \\
\text { (PES) 전산망 구축 } \\
\text { 지원(베트남) }\end{array}$ & 프로젝트 & 34.00 & 30.00 & 계속 & $\begin{array}{c}\text { 2017년 20 } \\
\text { 19년 }\end{array}$ & 양자무상 & 8 \\
\hline 7 & $\begin{array}{l}\text { 개도국 고용노동분야 } \\
\text { 개발협력(ODA) }\end{array}$ & $\begin{array}{l}\text { 개도국 고용서비스 } \\
\text { (PES) 전산망 구축 } \\
\text { 지원(캄보디아) }\end{array}$ & 프로젝트 & 34.00 & 2.00 & 신규 & $\begin{array}{c}\text { 2018년 20 } \\
20 \text { 년 }\end{array}$ & 양자무상 & 8 \\
\hline 8 & $\begin{array}{l}\text { 개도국 고용노동분야 } \\
\text { 개발협력(ODA) }\end{array}$ & $\begin{array}{l}\text { 개도국 직업훈련분야 } \\
\text { 역량강화(기능경기) }\end{array}$ & 연수사업 & 30.00 & 10.00 & 신규 & $\begin{array}{c}\text { 2018년 20 } \\
\text { 20년 }\end{array}$ & 양자무상 & 4 \\
\hline 9 & $\begin{array}{l}\text { 개도국 고용노동분야 } \\
\text { 개발협력(ODA) }\end{array}$ & 한-ILO 협력사업 & 기타기술협력 & 10.94 & 10.94 & 계속 & $\begin{array}{c}\text { 2004년 계 } \\
\text { 속 }\end{array}$ & 다자성양자 & 8 \\
\hline 10 & ILO 분담금 & ILO 분담금 & & 91.15 & 54.69 & 계속 & $\begin{array}{c}\text { 1992년 계 } \\
\text { 속 }\end{array}$ & 다자 & \\
\hline
\end{tabular}




\section{여성가족부 2018년도 ODA 예산 계획[안]}

$\square$ 총괄

(단위: 억원)

\begin{tabular}{l|c|c|c||c|c|c}
\hline \multirow{2}{*}{ ODA 시행부처(기관) } & \multicolumn{3}{|c||}{2017} & \multicolumn{3}{c}{2018 (요구) } \\
\cline { 2 - 7 } & 양자 무상 & 다자 & 합계 & 양자 무상 & 다자 & 합계 \\
\hline 여성가족부 & 19.9 & 45.6 & 65.5 & 10.7 & 54.7 & 65.4 \\
\hline
\end{tabular}

※ 다자성양자는 양자에 포함

○ '18년도 ODA 시행목표

- 수원국에 우리나라의 우수 여성정책을 공유·전수하고, 여성 역량강화를 위한 지원

으주요 정책과제

- 수원국 여성의 역량 강화를 위한 여성 특화 ODA 사업 추진을 통해 수원국 여성의 경제활동 참여 증진 및 지위 향상 도모

$\square$ 유형별 분류

(억원, \%)

\begin{tabular}{|c|c|c|c|c|c|c|c|c|c|c|c|c|}
\hline \multirow[b]{2}{*}{ 구분 } & \multirow[b]{2}{*}{ 계 } & \multirow[b]{2}{*}{$\begin{array}{l}\text { 프로 } \\
\text { 젝트 }\end{array}$} & \multirow[b]{2}{*}{$\begin{array}{l}\text { 프로 } \\
\text { 그램 }\end{array}$} & \multirow[b]{2}{*}{$\begin{array}{c}\text { 개발 } \\
\text { 컨설팅 }\end{array}$} & \multicolumn{4}{|c|}{ 기술협력 } & \multirow{2}{*}{$\begin{array}{c}\text { 민관 } \\
\text { 협력 } \\
\text { (NGO, } \\
\text { 기업) }\end{array}$} & \multirow[b]{2}{*}{$\begin{array}{l}\text { 행정 } \\
\text { 비용 }\end{array}$} & \multirow[b]{2}{*}{ 기타 } & \multirow[b]{2}{*}{$\begin{array}{l}\text { 순수 } \\
\text { 다자* }\end{array}$} \\
\hline & & & & & $\begin{array}{l}\text { 연수 } \\
\text { 사업 }\end{array}$ & $\begin{array}{l}\text { 장학 } \\
\text { 지원 }\end{array}$ & $\begin{array}{l}\text { 봉사단 } \\
\text { 파견 }\end{array}$ & $\begin{array}{l}\text { 기타 } \\
\text { 기술 } \\
\text { 협력 }\end{array}$ & & & & \\
\hline \multirow{2}{*}{ '17년 } & 65.5 & - & - & - & 3.0 & - & - & 15.1 & 1.8 & - & - & 45.6 \\
\hline & 100 & - & - & - & 4.6 & - & - & 23.0 & 2.8 & - & - & 69.6 \\
\hline '18년 & 65.4 & 5.95 & - & - & 3.0 & - & - & - & 1.8 & - & - & 54.65 \\
\hline (요구) & 100 & 9.1 & $\begin{array}{l}\cdots \\
-\end{array}$ & $\begin{array}{l}\cdots \\
-\end{array}$ & 4.5 & - & $\begin{array}{l}\cdots \\
-\end{array}$ & $\begin{array}{l}\cdots \\
-\end{array}$ & 2.7 & $\cdots$ & $\cdots$ & 83.6 \\
\hline
\end{tabular}

* 다자성양자를 제외한 순수다자만 해당되며, 다자성양자는 사업 유형에 맞게 분류

$\square$ 총 사업 목록

\begin{tabular}{|c|c|c|c|c|c|c|c|c|c|}
\hline & 세부사업명 & 내역사업명 & 사업 유형 & $\begin{array}{c}\text { 총사업예산 } \\
\text { (억원) }\end{array}$ & $\begin{array}{l}18 \text { 년 예산 } \\
\text { (억원) }\end{array}$ & $\begin{array}{l}\text { 신규/ } \\
\text { 계속 }\end{array}$ & $\begin{array}{l}\text { 총사업 } \\
\text { 기간 }\end{array}$ & $\begin{array}{c}\text { 구분 } \\
\text { (양-다자) }\end{array}$ & $\begin{array}{l}\text { SDGs } \\
\text { 목표 }\end{array}$ \\
\hline 1 & 국제개발협력(ODA) & $\begin{array}{l}\text { 개도국 여성직업능력 } \\
\text { 개발 교육훈련 }\end{array}$ & 연수사업 & 3.00 & 3.00 & 신규 & 2018 & 양자무상 & 5 \\
\hline 2 & 국제개발협력(ODA) & $\begin{array}{l}\text { 개도국 여성직업능력 } \\
\text { 개발 지원 }\end{array}$ & 프로젝트 & 5.95 & 5.95 & 계속 & $2016 \sim 2018$ & 양자무상 & 5 \\
\hline 3 & 국제개발협력(ODA) & $\begin{array}{l}\text { 개도국 성매매 등 여 } \\
\text { 성폭력 방지 및 피해 } \\
\text { 자 지원 }\end{array}$ & 민관협력 & 1.81 & 1.81 & 계속 & $2013-2019$ & 양자무상 & 5 \\
\hline 4 & $\begin{array}{l}\begin{array}{l}\text { 유엔여성기구 기여금 } \\
\text { (ODA) }\end{array} \\
\end{array}$ & 유엔여성기구 기여금 & & & 54.65 & 계속 & $2011 \sim$ & 다자 & \\
\hline
\end{tabular}


$\square$ 총괄

(단위: 억원)

\begin{tabular}{l|c|c|c||c|c|c}
\hline \multirow{2}{*}{ ODA 시행부처(기관) } & \multicolumn{3}{|c||}{2017} & \multicolumn{3}{c}{2018 (요구) } \\
\cline { 2 - 7 } & 양자 무상 & 다자 & 합계 & 양자 무상 & 다자 & 합계 \\
\hline 국토교통부 & 127.6 & 1.6 & 129.2 & 214.5 & 1.5 & 216.0 \\
\hline
\end{tabular}

※ 다자성양자는 양자에 포함

○ '18년도 ODA 시행목표

- 인프라 개발협력을 통해 2030 지속가능 개발목표(SDGs) '목표99 지속가능 산업화 및 혁신, '목표(11) 지속가 능도시', '목표(6) 물과 위생 달성에 기여'

$\square$ 유형별 분류

(억원, \%)

\begin{tabular}{|c|c|c|c|c|c|c|c|c|c|c|c|c|}
\hline \multirow[b]{2}{*}{ 구분 } & \multirow[b]{2}{*}{ 계 } & \multirow[b]{2}{*}{$\begin{array}{l}\text { 프로 } \\
\text { 젝트 }\end{array}$} & \multirow[b]{2}{*}{$\begin{array}{l}\text { 프로 } \\
\text { 그램 }\end{array}$} & \multirow[b]{2}{*}{$\begin{array}{l}\text { 개발 } \\
\text { 컨설팅 }\end{array}$} & \multicolumn{4}{|c|}{ 기술협력 } & \multirow{2}{*}{$\begin{array}{c}\text { 민관 } \\
\text { 협력 } \\
\text { (NGO, } \\
\text { 기업) }\end{array}$} & \multirow[b]{2}{*}{$\begin{array}{l}\text { 행정 } \\
\text { 비용 }\end{array}$} & \multirow[b]{2}{*}{ 기타 } & \multirow[b]{2}{*}{$\begin{array}{l}\text { 순수 } \\
\text { 다자* }\end{array}$} \\
\hline & & & & & 연수 & $\begin{array}{l}\text { 장학 } \\
\text { 지원 }\end{array}$ & $\begin{array}{l}\text { 봉사단 } \\
\text { 파견 }\end{array}$ & $\begin{array}{l}\text { 기타 } \\
\text { 기술 } \\
\text { 협력 }\end{array}$ & & & & \\
\hline \multirow{2}{*}{ '17년 } & 129.2 & 5.3 & 32.0 & 83.4 & 6.9 & - & - & - & - & - & - & 1.6 \\
\hline & 100 & 4.1 & 24.8 & 64.5 & 5.3 & - & - & $\begin{array}{l}\cdots \\
-\end{array}$ & - & - & - & 1.3 \\
\hline '18년 & 216.0 & 98.0 & - & 106.3 & 10.0 & - & - & - & - & - & 0.2 & 1.5 \\
\hline (요구) & 100 & 45.4 & $\begin{array}{l}\cdots \\
-\end{array}$ & 49.2 & 4.6 & - & - & - & - & $\begin{array}{l}\cdots \\
-\end{array}$ & 0.1 & 0.7 \\
\hline
\end{tabular}

* 다자성양자를 제외한 순수다자만 해당되며, 다자성양자는 사업 유형에 맞게 분류

$\square$ 총 사업 목록

\begin{tabular}{|c|c|c|c|c|c|c|c|c|c|}
\hline & 세부사업명 & 내역사업명 & 사업 유형 & $\begin{array}{l}\text { 총사업 예산 } \\
\text { (억원) }\end{array}$ & $\begin{array}{c}\begin{array}{c}18 \text { 년예산 } \\
\text { (억원) }\end{array} \\
\end{array}$ & $\begin{array}{l}\text { 신규/ } \\
\text { 계속 }\end{array}$ & $\begin{array}{l}\text { 총사업 } \\
\text { 기간 }\end{array}$ & $\begin{array}{c}\text { 구분 } \\
\text { (양-다자) }\end{array}$ & $\begin{array}{l}\text { SDGs } \\
\text { 목표 }\end{array}$ \\
\hline 1 & $\begin{array}{l}\text { 국제개발협력사업지원 } \\
\text { (ODA) }\end{array}$ & $\begin{array}{l}\text { 베트남 도로 중온 아 } \\
\text { 스팔트 기술 최적화 } \\
\text { 사업 }\end{array}$ & 프로젝트 & 20.00 & 7.00 & 신규 & $18-' 20$ & 양자무상 & 11 \\
\hline 2 & $\begin{array}{l}\text { 국제개발협력사업지원 } \\
\text { (ODA) }\end{array}$ & $\begin{array}{l}\text { 인도네시아 덴파사르 } \\
\text { 스마트 물관리 } \\
\text { (SWM) }\end{array}$ & 개발컨설팅 & 12.00 & 12.00 & 신규 & 2018 & 양자무상 & 9 \\
\hline 3 & $\begin{array}{l}\text { 국제개발협력사업지원 } \\
\text { (ODA) }\end{array}$ & $\begin{array}{l}\text { 우즈베키스탄 상수도 } \\
\text { 인프라 개선 사업 }\end{array}$ & 개발컨설팅 & 10.00 & 10.00 & 신규 & 2018 & 양자무상 & 9 \\
\hline 4 & $\begin{array}{l}\text { 국제개발협력사업지원 } \\
\text { (ODA) }\end{array}$ & $\begin{array}{l}\text { 페루 리막강 통합수자 } \\
\text { 원관리 사업 }\end{array}$ & 프로젝트 & 50.00 & 9.00 & 신규 & $18-22$ & 양자무상 & 6 \\
\hline 5 & $\begin{array}{l}\text { 국제개발협력사업지원 } \\
\text { (ODA) }\end{array}$ & $\begin{array}{l}\text { 요르단 북부지역 스마 } \\
\text { 트 물 관리 사업 }\end{array}$ & 개발컨설팅 & 10.00 & 10.00 & 신규 & 2018 & 양자무상 & 6 \\
\hline 6 & $\begin{array}{l}\text { 국제개발협력사업지원 } \\
\text { (ODA) }\end{array}$ & $\begin{array}{l}\text { 에티오피아 국가표준 } \\
\text { 통합 토지인프라 구 } \\
\text { 축 사업 }\end{array}$ & 개발컨설팅 & 10.00 & 10.00 & 신규 & 2018 & 양자무상 & 6 \\
\hline 7 & $\begin{array}{l}\text { 국제개발협력사업지원 } \\
\text { (ODA) }\end{array}$ & \begin{tabular}{|l} 
캄보디아 국가 토지정 \\
보인프라 사업
\end{tabular} & 개발컨설팅 & 10.00 & 10.00 & 신규 & 2018 & 양자무상 & 6 \\
\hline 8 & $\begin{array}{l}\text { 국제개발협력사업지원 } \\
\text { (ODA) }\end{array}$ & $\begin{array}{l}\text { 라오스 토지정보인프 } \\
\text { 라 구축 사업 }\end{array}$ & 개발컨설팅 & 10.00 & 10.00 & 신규 & 2018 & 양자무상 & 9 \\
\hline 9 & $\begin{array}{l}\begin{array}{l}\text { 국제개발협력사업지원 } \\
\text { (ODA) }\end{array} \\
\end{array}$ & \begin{tabular}{|l|} 
개발도상국 고위공무 \\
원 및 주한공관원 초 \\
청연수
\end{tabular} & 연수사업 & 10.00 & 10.00 & 신규 & 2018 & 양자무상 & 9 \\
\hline
\end{tabular}




\begin{tabular}{|c|c|c|c|c|c|c|c|c|c|}
\hline & 세부사업명 & 내역사업명 & 사업 유형 & $\begin{array}{c}\text { 총사업 예산 } \\
\text { (억원) }\end{array}$ & $\begin{array}{c}\text { '18년예산 } \\
\text { (억원) }\end{array}$ & \begin{tabular}{|l|} 
신규/ \\
계속 \\
\end{tabular} & $\begin{array}{l}\text { 총사업 } \\
\text { 기간 }\end{array}$ & \begin{tabular}{|c|} 
구분 \\
(양-다자)
\end{tabular} & $\begin{array}{l}\text { SDGs } \\
\text { 목표 }\end{array}$ \\
\hline & $\begin{array}{l}\text { 국제개발협력사업지원 } \\
\text { (ODA) }\end{array}$ & $\begin{array}{l}\text { 사업기획컨설팅(아시 } \\
\text { 아등13개중점협력국) } \\
\text {-CLMV,인니, 필리핀, } \\
\text { 네팔,방를라,스리랑카, } \\
\text { 파키스탄, } \\
\text { 몽골, 우즈벡, 아제 } \\
\text { 르바이잔 }\end{array}$ & 개발컨설팅 & 2.00 & 2.00 & 신규 & 2018 & 양자무상 & 9 \\
\hline 11 & $\begin{array}{l}1 \text { 국제개발협력사업지원 } \\
\text { (ODA) }\end{array}$ & $\begin{array}{l}\text { 사업기획컨설팅(중남 } \\
\text { 미 } 4 \text { 개중점협력국) } \\
\text { - 볼리비아, 파라과이, } \\
\text { 콜롬비아,페루 }\end{array}$ & 개발컨설팅 & 1.00 & 1.00 & 신규 & 2018 & 양자무상 & 9 \\
\hline & $\begin{array}{l}\text { 국제개발협력사업지원 } \\
\text { (ODA) }\end{array}$ & $\begin{array}{l}\text { 사업기획컨설팅(아프 } \\
\text { 리카7개중점협력국) } \\
\text {-가나,세네가, ,르완다, } \\
\text { 모잠비크,에티오피아, } \\
\text { 우간다, 탄자니아 }\end{array}$ & 개발컨설팅 & 1.00 & 1.00 & 신규 & 2018 & 양자무상 & 9 \\
\hline & $\begin{array}{l}\text { 국제개발협력사업지원 } \\
\text { (ODA) }\end{array}$ & $\begin{array}{l}\text { 페루 아레키파 도시 } \\
\text { 교통(ITS 등) 개발 }\end{array}$ & 개발컨설팅 & 10.00 & 10.00 & 신규 & 2018 & 양자무상 & 9 \\
\hline & $\begin{array}{l}\text { 국제개발협력사업지원 } \\
\text { (ODA) }\end{array}$ & $\begin{array}{l}\text { 콜롬비아 메데진시 } \\
\text { 도심지교통 기능향상 } \\
\text { 사업 }\end{array}$ & 프로젝트 & 150.00 & 50.00 & 신규 & $2018 \sim 2020$ & 양자무상 & 9 \\
\hline & $\begin{array}{l}\text { 유네스코 개도국 물 } \\
\text { 안보 정책 수립 지원 }\end{array}$ & $\begin{array}{l}\text { 유네스코 개도국 물 } \\
\text { 안보 정책 수립 지원 }\end{array}$ & 개발컨설팅 & 300.00 & 18.00 & 신규 & $\begin{array}{c}2018 \sim 2027 \\
\text { (10년간) }\end{array}$ & 다자성양자 & 13 \\
\hline & 유엔 아프리카 자원 & $\begin{array}{l}\text { 유엔 아프리카 자원공 } \\
\text { 간정보 구축 }\end{array}$ & 프로젝트 & 135.00 & 32.00 & 계속 & $2016-2020$ & 다자성양자 & 7 \\
\hline & $\begin{array}{l}\text { 유엔 해비타트 개도 } \\
\text { 국 도시지원 }\end{array}$ & $\begin{array}{l}\text { 개도국 신도시개발 및 } \\
\text { 도시정책 수립 지원 }\end{array}$ & 개발컨설팅 & 30.00 & 12.30 & 계속 & 2017 2019 & 다자성양자 & 11 \\
\hline & 3 UN ESCAP 분담금 & UN ESCAP 분담금 & 기타 & 0.15 & 0.15 & 계속 & $\begin{array}{c}1993 \text { 년 - 계 } \\
\text { 속 }\end{array}$ & 다자성양자 & 11 \\
\hline & $\begin{array}{l}\text { 기타국제기구분담금 } \\
\text { (ODA) }\end{array}$ & $\begin{array}{l}\text { UN-HABITAT 분담 } \\
\text { 금 }\end{array}$ & & & 1.50 & 계속 & 2004 계속 & 다자 & \\
\hline
\end{tabular}




\section{해양수산부 2018년도 ODA 예산 계획[안]}

$\square$ 총괄

(단위: 억원)

\begin{tabular}{l|c|c|c||c|c|c}
\hline \multirow{2}{*}{ ODA 시행부처(기관) } & \multicolumn{3}{|c||}{2017} & \multicolumn{3}{c}{2018 (요구) } \\
\cline { 2 - 7 } & 양자 무상 & 다자 & 합계 & 양자 무상 & 다자 & 합계 \\
\hline 해양수산부 & 47.7 & - & 47.7 & 167.2 & - & 167.2 \\
\hline
\end{tabular}

※ 다자성양자는 양자에 포함

○ '18년도 ODA 시행목표

- 연안 개도국의 해양수산 분야 기반구축을 통한 빈곤해소 및 해양수산협력 강화를 통한 아국 해외 어장의 안정적 조업기반 확보

우주요 정책과제

- 안정적인 해외 해양수산자원 확보를 위해 해양.수산 ODA 중장기 발전계획 수립·시행

· 연안 개도국 해양수산 인프라시설구축 및 전문가 파견

· 개도국 공무원 및 연구·전문가에 대한 해양수산기술 및 정책교육

\section{유형별 분류}

(억원, \%)

\begin{tabular}{|c|c|c|c|c|c|c|c|c|c|c|c|c|}
\hline \multirow[b]{2}{*}{ 구분 } & \multirow[b]{2}{*}{ 계 } & \multirow[b]{2}{*}{$\begin{array}{l}\text { 프로 } \\
\text { 젝트 }\end{array}$} & \multirow[b]{2}{*}{$\begin{array}{l}\text { 프로 } \\
\text { 르램 }\end{array}$} & \multirow[b]{2}{*}{$\begin{array}{l}\text { 개발 } \\
\text { 컨설팅 }\end{array}$} & \multicolumn{4}{|c|}{ 기술협력 } & \multirow{2}{*}{$\begin{array}{c}\text { 민관 } \\
\text { 협력 } \\
\text { (NGO, } \\
\text { 기업) }\end{array}$} & \multirow[b]{2}{*}{$\begin{array}{l}\text { 행정 } \\
\text { 비용 }\end{array}$} & \multirow[b]{2}{*}{ 기타 } & \multirow[b]{2}{*}{$\begin{array}{l}\text { 순수 } \\
\text { 다자* }\end{array}$} \\
\hline & & & & & $\begin{array}{l}\text { 연수 } \\
\text { 사업 }\end{array}$ & $\begin{array}{l}\text { 장항 } \\
\text { 지원 }\end{array}$ & $\begin{array}{l}\text { 봉사단 } \\
\text { 파견 }\end{array}$ & $\begin{array}{l}\text { 기타 } \\
\text { 기술 } \\
\text { 협력 }\end{array}$ & & & & \\
\hline \multirow{2}{*}{ '17년 } & 47.7 & 40.0 & - & - & 2.9 & - & - & 4.7 & - & - & - & - \\
\hline & 100 & 84.0 & - & - & 6.2 & - & - & 9.9 & - & - & - & - \\
\hline '18년 & 167.2 & 158.7 & - & - & 3.8 & - & - & 4.7 & - & - & - & - \\
\hline (요구) & 100 & 94.9 & - & - & 2.3 & - & - & 2.8 & - & - & - & - \\
\hline
\end{tabular}

* 다자성양자를 제외한 순수다자만 해당되며, 다자성양자는 사업 유형에 맞게 분류

$\square$ 총 사업 목록

\begin{tabular}{|c|c|c|c|c|c|c|c|c|c|}
\hline & 세부사업명 & 내역사업명 & 사업 유형 & $\begin{array}{l}\text { 총사업 예산 } \\
\text { (억원) }\end{array}$ & $\begin{array}{l}\text { '18년예산 } \\
\text { (억원) }\end{array}$ & $\begin{array}{l}\text { 신규/ } \\
\text { 계속 }\end{array}$ & $\begin{array}{l}\text { 총사업 } \\
\text { 기간 }\end{array}$ & $\begin{array}{c}\text { 구분 } \\
\text { (양-다자) }\end{array}$ & $\begin{array}{l}\text { SDGs } \\
\text { 목표 }\end{array}$ \\
\hline 1 & $\begin{array}{l}\text { 연안국과의 협력 } \\
\text { (ODA) }\end{array}$ & $\begin{array}{l}\text { 해양수산 국제협력 컨 } \\
\text { 퍼런스 }\end{array}$ & 기타기술협력 & 4.70 & 4.70 & 신규 & 2018 & 양자무상 & 14 \\
\hline 2 & $\begin{array}{l}\text { 연안국과의 협력 } \\
\text { (ODA) }\end{array}$ & $\begin{array}{l}\text { 해외수산위생시설지원 } \\
\text { (에콰도르) }\end{array}$ & 프로젝트 & 15.04 & 2.61 & 계속 & $2015-2019$ & 양자무상 & 4 \\
\hline 3 & $\begin{array}{l}\text { 연안국과의 협력 } \\
\text { (ODA) }\end{array}$ & $\begin{array}{l}\text { 필리핀 해양수산 인프 } \\
\text { 라 시설 구축 }\end{array}$ & 프로젝트 & 48.30 & 33.70 & 계속 & $2015 \sim 2018$ & 양자무상 & 14 \\
\hline 4 & $\begin{array}{l}\text { 연안국과의 협력 } \\
\text { (ODA) }\end{array}$ & $\begin{array}{l}\text { 피지 기후변화 대응역 } \\
\text { 량 강화 }\end{array}$ & 프로젝트 & 59.00 & 31.50 & 계속 & $2016 \sim 2020$ & 양자무상 & 13 \\
\hline 5 & $\begin{array}{l}\text { 연안국과의 협력 } \\
\text { (ODA) }\end{array}$ & $\begin{array}{l}\text { 연안 개발도상국 수 } \\
\text { 산인프라지원(키리바 } \\
\text { 시) }\end{array}$ & 프로젝트 & 8.80 & 2.20 & 계속 & $2017-2018$ & 양자무상 & 14 \\
\hline
\end{tabular}




\begin{tabular}{|c|c|c|c|c|c|c|c|c|c|}
\hline & 세부사업명 & 내역사업명 & 사업 유형 & $\begin{array}{c}\text { 총사업예산 } \\
\text { (억원) }\end{array}$ & $\begin{array}{l}\text { '18년예산 } \\
\text { (억원) }\end{array}$ & $\begin{array}{l}\text { 신규/ } \\
\text { 계속 }\end{array}$ & $\begin{array}{l}\text { 총사업 } \\
\text { 기간 }\end{array}$ & \begin{tabular}{|c|} 
구분 \\
(양-다자)
\end{tabular} & $\begin{array}{l}\mathrm{SDGS} \\
\text { 목표 }\end{array}$ \\
\hline 6 & $\begin{array}{l}\text { 연안국과의 협력 } \\
\text { (ODA) }\end{array}$ & 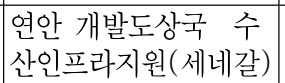 & 프로젝트 & 8.80 & 4.40 & 계속 & $2017-2018$ & 양자무상 & 4 \\
\hline 7 & $\begin{array}{l}\text { 연안국과의 협력 } \\
\text { (ODA) }\end{array}$ & $\begin{array}{l}\text { 수산인프라구축지원사 } \\
\text { 업(선원학교 교육훈 } \\
\text { 련 및 역량강화) }\end{array}$ & 프로젝트 & 15.00 & 3.75 & 계속 & $2017 \sim 2020$ & 양자무상 & 4 \\
\hline 8 & $\begin{array}{l}\text { 연안국과의 협력 } \\
\text { (ODA) }\end{array}$ & $\begin{array}{l}\text { 연안도서국 수산기술 } \\
\text { 및 교육 정책연수 }\end{array}$ & 연수사업 & 2.00 & 2.00 & 신규 & 2018 & 양자무상 & 4 \\
\hline 9 & $\begin{array}{l}\text { 연안국과의 협력 } \\
\text { (ODA) }\end{array}$ & $\begin{array}{l}\text { 캄보디아연안·해양환 } \\
\text { 경관리역량강화 }\end{array}$ & 연수사업 & 4.50 & 1.78 & 신규 & $2017-2019$ & 양자무상 & 14 \\
\hline & $\begin{array}{l}\text { 연안국과의 협력 } \\
\text { (ODA) }\end{array}$ & $\begin{array}{l}\text { 연안 개발도상국 수 } \\
\text { 산인프라지원(가나) }\end{array}$ & 프로젝트 & 8.80 & 4.40 & 신규 & $2018-2019$ & 양자무상 & 4 \\
\hline & $\begin{array}{l}\text { 연안국과의 협력 } \\
\text { (ODA) }\end{array}$ & $\begin{array}{l}\text { 열대관상어자원 개발 } \\
\text { 및 기술전수 }\end{array}$ & 프로젝트 & 35.00 & 7.00 & 계속 & $2017 \sim 2021$ & 양자무상 & 14 \\
\hline & $\begin{array}{l}\text { 연안국과의 협력 } \\
\text { (ODA) }\end{array}$ & $\begin{array}{l}\text { 태평양소도서국 해양 } \\
\text { 산성화 관측 및 대응 } \\
\text { 네트워크 구축 }\end{array}$ & 프로젝트 & 60.00 & 17.00 & 신규 & $2018 \sim 2021$ & 다자성양자 & 14 \\
\hline & $\begin{array}{l}\text { 연안국과의 협력 } \\
\text { (ODA) }\end{array}$ & \begin{tabular}{|l} 
서부아프리카 통합 \\
IUU어업 감시시스템 \\
구축
\end{tabular} & 프로젝트 & 27.61 & 8.09 & 신규 & $2018-2022$ & 다자성양자 & 14 \\
\hline & $\begin{array}{l}\text { 연안국과의 협력 } \\
\text { (ODA) }\end{array}$ & \begin{tabular}{|l|} 
키리바시 해수를 이용 \\
한 식수 및 식량생산 \\
시스템 지원사업
\end{tabular} & 프로젝트 & 7.00 & 4.00 & 신규 & $2018-2020$ & 양자무상 & 14 \\
\hline & $\begin{array}{l}\text { 연안국과의 협력 } \\
\text { (ODA) }\end{array}$ & $\begin{array}{l}\text { 투발루해수온도차발전 } \\
\text { 기획및이용역량강화사 } \\
\text { 업 }\end{array}$ & 프로젝트 & 9.00 & 3.00 & 신규 & $2018-2020$ & 양자무상 & 14 \\
\hline & $\begin{array}{l}\begin{array}{l}\text { 연안국과의 협력 } \\
\text { (ODA) }\end{array} \\
\end{array}$ & \begin{tabular}{|l|} 
연안 개발도상국 수 \\
산인프라지원(피지)
\end{tabular} & 프로젝트 & 8.80 & 4.40 & 신규 & $2018-2019$ & 양자무상 & 14 \\
\hline & $\begin{array}{l}\text { 연안국과의 협력 } \\
\text { (ODA) }\end{array}$ & $\begin{array}{l}\text { 세네갈 수산물 품질관 } \\
\text { 리 연구소 건설지원 } \\
\text { 사업 }\end{array}$ & 프로젝트 & 25.74 & 8.44 & 신규 & $2018-2021$ & 양자무상 & 4 \\
\hline & $\begin{array}{l}\text { 연안국과의 협력 } \\
\text { (ODA) }\end{array}$ & $\begin{array}{l}\text { 베트남 연안 수산자원 } \\
\text { 조성·관리 모델 구축 }\end{array}$ & 프로젝트 & 19.70 & 1.60 & 신규 & $2018-2022$ & 양자무상 & 14 \\
\hline & $\begin{array}{l}\text { 연안국과의 협력 } \\
\text { (ODA) }\end{array}$ & $\begin{array}{l}\text { 콜롬비아 해양예보시 } \\
\text { 스템 연구능력 확충 }\end{array}$ & 프로젝트 & 20.00 & 5.00 & 신규 & $2018 \sim 2021$ & 양자무상 & 14 \\
\hline 2 & $\begin{array}{l}\text { 연안국과의 협력 } \\
\text { (ODA) }\end{array}$ & $\begin{array}{l}\text { 미얀마 한국형 해상가 } \\
\text { 두리 시범 양식장 지 } \\
\text { 원사업 }\end{array}$ & 프로젝트 & 11.10 & 5.55 & 신규 & $2018-2019$ & 양자무상 & 4 \\
\hline & $\begin{array}{l}\text { 연안국과의 협력 } \\
\text { (ODA) }\end{array}$ & $\begin{array}{l}\text { 해양 및 연안 기초조 } \\
\text { 사와 역량강화 }\end{array}$ & 프로젝트 & 50.00 & 12.00 & 신규 & $2018-2021$ & 양자무상 & 13 \\
\hline
\end{tabular}




\section{국민안전처 2018년도 ODA 예산 계획[안]}

$\square$ 총괄

(단위: 억원)

\begin{tabular}{l|c|c|c||c|c|c}
\hline \multirow{2}{*}{ ODA 시행부처(기관) } & \multicolumn{3}{|c||}{2017} & \multicolumn{3}{c}{2018 (요구) } \\
\cline { 2 - 7 } & 양자 무상 & 다자 & 합계 & 양자 무상 & 다자 & 합계 \\
\hline 국민안전처 & 8.3 & - & 8.3 & 18.5 & - & 18.5 \\
\hline
\end{tabular}

※ 다자성양자는 양자에 포함

○ '18년도 ODA 시행목표

- 재난안전 기술이전을 통한 협력대상국 재난대응 역량 강화

- 협력대상국 총괄기관 요청중심의 ODA사업 추진

- 중소기업 참여기회 확대를 통한 창조경제 정부 3.0 목표 수행

- 재난관리 역량강화를 통한 수원국 자연재해 저감

- ICT를 활용한 체계적이고 효율적인 재난관리 시스템 전파

- 방재분야 선점 및 진출 교두보 마련

으주요 정책과제

- '14년 한-ASEAN 특별정상회담 제2섹션 정부 발표자료('14.12.), ASEAN 재난대응 역량강화 지원을 위하여 우리나라 $\mathrm{ODA}$ 중점협력사업에 방재분야 추가에 따른 후속조치

- ' 14 년 12 월, 제 16 차 국가과학기술자문회의에서 재난 과학기술 분야 아세안 국가와 협력강화 제시

- (SDGs 목표)

- (11) 포용적이고 안전하며 회복력 있고 지속가능한 도시와 정주지 조성

· (13) 기후변화와 그 영향을 방지하기 위한 긴급한 행동의 실시

$\square$ 유형별 분류

(억원, \%)

\begin{tabular}{|c|c|c|c|c|c|c|c|c|c|c|c|c|}
\hline \multirow[b]{2}{*}{ 구분 } & \multirow[b]{2}{*}{ 계 } & \multirow[b]{2}{*}{$\begin{array}{l}\text { 프로 } \\
\text { 젝트 }\end{array}$} & \multirow[b]{2}{*}{$\begin{array}{l}\text { 프로 } \\
\text { 그램 }\end{array}$} & \multirow[b]{2}{*}{$\begin{array}{l}\text { 개발 } \\
\text { 컨설팅 }\end{array}$} & \multicolumn{4}{|c|}{ 기술협력 } & \multirow{2}{*}{$\begin{array}{c}\text { 민관 } \\
\text { 협력 } \\
\text { (NGO, } \\
\text { 기업) }\end{array}$} & \multirow[b]{2}{*}{$\begin{array}{l}\text { 행정 } \\
\text { 비용 }\end{array}$} & \multirow[b]{2}{*}{ 기타 } & \multirow[b]{2}{*}{$\begin{array}{l}\text { 순수 } \\
\text { 다자* }\end{array}$} \\
\hline & & & & & $\begin{array}{l}\text { 연수 } \\
\text { 사업 }\end{array}$ & $\begin{array}{l}\text { 장학 } \\
\text { 지원 }\end{array}$ & $\begin{array}{l}\text { 봉사단 } \\
\text { 파견 }\end{array}$ & $\begin{array}{l}\text { 기타 } \\
\text { 기술 } \\
\text { 협력 }\end{array}$ & & & & \\
\hline \multirow{2}{*}{ '17년 } & 8.3 & 8.3 & - & - & - & - & - & - & - & - & - & - \\
\hline & 100 & 100 & $\begin{array}{l}\cdots \\
-\end{array}$ & $\begin{array}{c}\cdots \\
-\end{array}$ & $\begin{array}{l}\cdots \\
-\end{array}$ & - & - & $\begin{array}{l}\cdots \\
-\end{array}$ & $\begin{array}{l}\cdots \\
-\end{array}$ & - & - & $\begin{array}{l}\cdots \\
-\end{array}$ \\
\hline '18년 & 18.5 & 15.0 & - & - & 3.5 & - & - & - & - & - & - & - \\
\hline (요구) & 100 & 81.1 & $\begin{array}{l}\cdots \\
-\end{array}$ & $\begin{array}{l}\cdots \\
-\end{array}$ & 18.9 & - & - & $\begin{array}{l}\cdots \\
-\end{array}$ & - & - & - & $\begin{array}{l}\cdots \\
-\end{array}$ \\
\hline
\end{tabular}

* 다자성양자를 제외한 순수다자만 해당되며, 다자성양자는 사업 유형에 맞게 분류 
$\square$ 총 사업 목록

\begin{tabular}{|c|c|c|c|c|c|c|c|c|c|}
\hline & 세부사업명 & 내역사업명 & 사업 유형 & $\begin{array}{c}\begin{array}{c}\text { 총사업 예산 } \\
\text { (억원) }\end{array}\end{array}$ & $\begin{array}{l}\text { '18년예산 } \\
\text { (억원) }\end{array}$ & \begin{tabular}{|l} 
신규/ \\
계속
\end{tabular} & $\begin{array}{l}\text { 총사업 } \\
\text { 기간 }\end{array}$ & \begin{tabular}{c|} 
구분 \\
(양-다자)
\end{tabular} & $\begin{array}{l}\text { SDGs } \\
\text { 목표 }\end{array}$ \\
\hline 1 & $\begin{array}{l}\text { 재난안전 신기술 } \\
\text { 해외보큽(ODA) }\end{array}$ & $\begin{array}{l}\text { 재난안전신기술해외보 } \\
\text { 급(ODA) } \\
\text { (라오스) }\end{array}$ & 프로젝트 & 15.65 & 7.50 & 계속 & 2016 2018 & 양자무상 & 13 \\
\hline 2 & $\begin{array}{l}\text { 재난안전 신기술 } \\
\text { 해외보급(ODA) }\end{array}$ & $\begin{array}{l}\text { 재난안전신기술해외보 } \\
\text { 급(ODA) } \\
\text { (베트남) }\end{array}$ & 프로젝트 & 15.65 & 7.50 & 계속 & 2016 2018 & 양자무상 & 13 \\
\hline 3 & $\begin{array}{l}\text { 재난관리 } \\
\text { 역량강화사업(ODA) }\end{array}$ & $\begin{array}{l}\text { 우간다 재난관리 } \\
\text { 역량강화사업 }\end{array}$ & 연수사업 & 7.40 & 1.75 & 신규 & 2018 2020 & 양자무상 & 11 \\
\hline 4 & $\begin{array}{l}\text { 재난관리 } \\
\text { 역량강화사업(ODA) }\end{array}$ & $\begin{array}{l}\text { 키르기즈스탄 } \\
\text { 재난관리 } \\
\text { 역량강화사업 }\end{array}$ & 연수사업 & 7.40 & 1.75 & 신규 & 2018 2020 & 양자무상 & 11 \\
\hline
\end{tabular}




\section{인사혁신처 2018년도 ODA 예산 계획[안]}

$\square$ 총괄

(단위: 억원)

\begin{tabular}{l|c|c|c||c|c|c}
\hline \multirow{2}{*}{ ODA 시행부처(기관) } & \multicolumn{3}{|c||}{2017} & \multicolumn{3}{c}{2018 (요구) } \\
\cline { 2 - 7 } & 양자 무상 & 다자 & 합계 & 양자 무상 & 다자 & 합계 \\
\hline 인사혁신처 & 107.1 & - & 107.1 & 113.2 & - & 113.2 \\
\hline
\end{tabular}

※ 다자성양자는 양자에 포함

유형별 분류

(억원, \%)

\begin{tabular}{|c|c|c|c|c|c|c|c|c|c|c|c|c|}
\hline \multirow[b]{2}{*}{ 구분 } & \multirow[b]{2}{*}{ 계 } & \multirow[b]{2}{*}{ 프로 } & \multirow[b]{2}{*}{$\begin{array}{l}\text { 프로 } \\
\text { 그램 }\end{array}$} & \multirow[b]{2}{*}{$\begin{array}{l}\text { 개발 } \\
\text { 컨설팅 }\end{array}$} & \multicolumn{4}{|c|}{ 기술협력 } & \multirow{2}{*}{$\begin{array}{c}\text { 민관 } \\
\text { 협력 } \\
\text { (NGO, } \\
\text { 기업) }\end{array}$} & \multirow[b]{2}{*}{$\begin{array}{l}\text { 행정 } \\
\text { 비용 }\end{array}$} & \multirow[b]{2}{*}{ 기타 } & \multirow[b]{2}{*}{$\begin{array}{l}\text { 순수 } \\
\text { 다자* }\end{array}$} \\
\hline & & & & & $\begin{array}{l}\text { 연수 } \\
\text { 사업 }\end{array}$ & $\begin{array}{l}\text { 장학 } \\
\text { 지원 }\end{array}$ & $\begin{array}{l}\text { 봉사단 } \\
\text { 파견 }\end{array}$ & $\begin{array}{l}\text { 기타 } \\
\text { 기술 } \\
\text { 협력 }\end{array}$ & & & & \\
\hline \multirow{2}{*}{ '17년 } & 107.1 & $\therefore$ & - & - & - & - & $\therefore$ & - & $\therefore$ & - & 107.1 & - \\
\hline & 100 & - & - & - & - & - & - & - & - & - & 100 & - \\
\hline '18년 & 113.2 & - & - & - & - & - & - & - & - & - & 113.2 & - \\
\hline (요구) & 100 & $\begin{array}{l}\cdots \\
-\end{array}$ & $\because$ & $\begin{array}{l}\cdots \\
-\end{array}$ & $\begin{array}{l}\cdots \\
-\end{array}$ & - & $\begin{array}{l}\cdots \\
-\end{array}$ & $\because$ & $\begin{array}{c}\cdots \\
-\end{array}$ & $\because$ & 100 & - \\
\hline
\end{tabular}

* 다자성양자를 제외한 순수다자만 해당되며, 다자성양자는 사업 유형에 맞게 분류

$\square$ 총 사업 목록

\begin{tabular}{l|c|c|c|c|c|c|c|c|c}
\hline & 세부사업명 & 내역사업명 & 사업 유형 & $\begin{array}{c}\text { 총사업 예산 } \\
\text { (억원) }\end{array}$ & $\begin{array}{c}18 \text { 년예산 } \\
\text { (억원) }\end{array}$ & $\begin{array}{l}\text { 신규/ } \\
\text { 계속 }\end{array}$ & $\begin{array}{c}\text { 총사업 } \\
\text { 기간 }\end{array}$ & $\begin{array}{c}\text { 구분 } \\
\text { (양-다자) }\end{array}$ & $\begin{array}{c}\text { SDGs } \\
\text { 목표 }\end{array}$ \\
\hline \multirow{2}{*}{$\begin{array}{l}\text { 국제기구고용휴직제도 } \\
\text { 운욱제깅ㄱㄱㄱ고용휴직제도 } \\
\text { 운영 }\end{array}$} & 기타 & & 113.2 & 계속 & & 다자성양자 & \\
\hline
\end{tabular}




\section{식품의약품안전처 2018년도 ODA 예산 계획[안]}

$\square$ 총괄

(단위: 억원)

\begin{tabular}{c|c|c|c||c|c|c}
\hline \multirow{2}{*}{$\mathrm{ODA}$ 시행부처(기관) } & \multicolumn{3}{|c||}{2017} & \multicolumn{3}{c}{2018 (요구) } \\
\cline { 2 - 7 } & 양자 무상 & 다자 & 합계 & 양자 무상 & 다자 & 합계 \\
\hline 식품의약품안전처 & 18.9 & - & 18.9 & 57.3 & - & 57.3 \\
\hline
\end{tabular}

※ 다자성양자는 양자에 포함

○ '18년도 ODA 시행목표

- 식약처의 식의약 안전 및 품질관리 컨트롤타워로서의 축척된 경험에 기초하여 지 속가능하고 전문성있는 ODA사업 추진을 위해 자체사업 신규 발굴 및 확대

- 식약처 $\mathrm{MOU}$ 체결국 또는 우리나라 FTA 체결국과 중점협력국 대상으로 식품 및 의료제품분야 역량강화 신규사업 발굴 추진, 대상국 확대

- 식약처 자체적으로 사후관리지침을 제정('17.2)하여 ODA사업 사후관리 기본방향 마련

으주요 정책과제

- 제2차 국제개발협력 기본계획(2016-2020)과 UN의 SDGs에 합치하도록 ODA성과의 지속적 확대

이기타

- 한·아세안 FTA 체결('07.6)

- 식약청과 인도네시아 식품의약품안전청간 식품, 의약품, 생약제제, 화장품, 건강기능식 품에 관한 양해각서('12.7)

- 식약처-페루 보건부간 협력 MOU 체결('16.1.29)

- 식약처-아르헨티나 식품의약품의료기술청간 기관협력 $\mathrm{MOU}$ 체결('16.12.7)

- 식약처-멕시코 보건부간 협력 $\mathrm{MOU}$ 체결('16.4.4)

- 식약처-에콰도르 공공보건부간 $\mathrm{MOU}$ 체결('14.3.11)

- 식약처-브라질 위생감시국간 MOU 체결('14.11.18)

- 한국-콜롬비아 FTA 발효('16.7.15)

- 식약처-베트남 보건부간 MOU체결('15.12.2)

- 식약처-WHO 서태평양지역사무처 $\mathrm{MOU}$ 체결('11)

\section{유형별 분류}

(억 원, \%)

\begin{tabular}{|c|c|c|c|c|c|c|c|c|c|c|c|c|}
\hline \multirow[b]{2}{*}{ 구분 } & \multirow[b]{2}{*}{ 계 } & \multirow[b]{2}{*}{ 프로 } & \multirow[b]{2}{*}{$\begin{array}{l}\text { 프로 } \\
\text { 그램 }\end{array}$} & \multirow[b]{2}{*}{$\begin{array}{l}\text { 개발 } \\
\text { 컨설팅 }\end{array}$} & \multicolumn{4}{|c|}{ 기술협력 } & \multirow{2}{*}{$\begin{array}{c}\text { 민관 } \\
\text { 협력 } \\
\text { (NGO, } \\
\text { 기업) }\end{array}$} & \multirow[b]{2}{*}{$\begin{array}{l}\text { 행정 } \\
\text { 비용 }\end{array}$} & \multirow[b]{2}{*}{ 기타 } & \multirow[b]{2}{*}{$\begin{array}{l}\text { 순수 } \\
\text { 다자* }\end{array}$} \\
\hline & & & & & $\begin{array}{l}\text { 연수 } \\
\text { 사업 }\end{array}$ & $\begin{array}{l}\text { 장학 } \\
\text { 지원 }\end{array}$ & $\begin{array}{l}\text { 봉사단 } \\
\text { 파견 }\end{array}$ & $\begin{array}{l}\text { 기타 } \\
\text { 기술 } \\
\text { 협력 }\end{array}$ & & & & \\
\hline \multirow{2}{*}{ '17년 } & 18.9 & 17.8 & - & - & - & - & - & 1.1 & - & - & 0.1 & - \\
\hline & 100 & 92.8 & $\begin{array}{l}\cdots \\
-\end{array}$ & - & 6.5 & - & $\begin{array}{c}\cdots \\
-\end{array}$ & - & - & - & 0.6 & - \\
\hline '18년 & 57.3 & 32.6 & - & - & 20.9 & - & - & 3.8 & - & - & 0.1 & - \\
\hline (요구) & 100 & 56.8 & $\begin{array}{l}\cdots \\
-\end{array}$ & - & 36.4 & - & $\begin{array}{l}\cdots \\
-\end{array}$ & 6.6 & $\begin{array}{c}\cdots \\
-\end{array}$ & - & 0.2 & - \\
\hline
\end{tabular}

* 다자성양자를 제외한 순수다자만 해당되며, 다자성양자는 사업 유형에 맞게 분류 


\section{$\square$ 총 사업 목록}

\begin{tabular}{|c|c|c|c|c|c|c|c|c|c|}
\hline & 세부사업명 & 내역사업명 & 사업 유형 & $\begin{array}{c}\text { 총사업 예산 } \\
\text { (억원) }\end{array}$ & $\begin{array}{c}\text { '18년예산 } \\
\text { (억원) }\end{array}$ & $\begin{array}{l}\text { 신규/ } \\
\text { 계속 }\end{array}$ & $\begin{array}{l}\text { 총사업 } \\
\text { 기간 }\end{array}$ & $\begin{array}{c}\text { 구분 } \\
\text { (양-다자) }\end{array}$ & $\begin{array}{l}\text { SDGs } \\
\text { 목표 }\end{array}$ \\
\hline 1 & $\begin{array}{l}\text { 아세안및개도국농축수 } \\
\text { 산물안전관리역량강화 } \\
\text { 세미나 }\end{array}$ & $\begin{array}{l}\text { 아세안및개도국농축수 } \\
\text { 산물안전관리역량강화 } \\
\text { 세미난 }\end{array}$ & $\begin{array}{c}\text { 기타기술협 } \\
\text { 력 }\end{array}$ & 1.15 & 1.15 & 신규 & 2018 & 양자무상 & 3 \\
\hline 2 & $\begin{array}{l}\text { 필리핀 식품검사능력 } \\
\text { 강화 }\end{array}$ & $\begin{array}{l}\text { 필리핀 식품검사능력 } \\
\text { 강화 }\end{array}$ & 프로젝트 & 6.94 & 2.63 & 신규 & $2018 \sim 2020$ & 양자무상 & 2 \\
\hline 3 & $\begin{array}{l}\text { 인도네시아 식품안전 } \\
\text { 역량강화 }\end{array}$ & $\begin{array}{l}\text { 인도네시아 식품안전 } \\
\text { 역량강화 }\end{array}$ & 연수사업 & 2.79 & 0.90 & 신규 & $2018-2020$ & 양자무상 & 2 \\
\hline 4 & $\begin{array}{l}\text { 중남미 생물의약품 } \\
\text { 허가심사 인력교육 }\end{array}$ & $\begin{array}{l}\text { 중남미 생물의약품 허 } \\
\text { 가심사 인력교육 }\end{array}$ & 연수사업 & 50.00 & 10.00 & 신규 & $2018-2022$ & 양자무상 & 3 \\
\hline 5 & $\begin{array}{l}\text { 개도국 화장품 규제 } \\
\text { 당국자 초청 연수 }\end{array}$ & $\begin{array}{l}\text { 개도국 화장품 규제당 } \\
\text { 국자 초청 연수 }\end{array}$ & 연수사업 & 50.00 & 10.00 & 신규 & $2018-2022$ & 양자무상 & 4 \\
\hline 6 & $\begin{array}{l}\text { 콜롬보플랜 마약자문 } \\
\text { 사업 }\end{array}$ & $\begin{array}{l}\text { 콜롬보플랜 마약자문 } \\
\text { 사업 }\end{array}$ & 기타 & 0.11 & 0.11 & 계속 & $\begin{array}{c}1998 \sim ~ \\
\text { 계속 }\end{array}$ & 다자성양자 & 3 \\
\hline 7 & $\begin{array}{l}\text { 식중독 감영 예방·대 } \\
\text { 응 네트워크 운영 }\end{array}$ & $\begin{array}{l}\text { 식중독 감영 예방·대 } \\
\text { 응 네트워크 운영 }\end{array}$ & 프로젝트 & 13.00 & 2.60 & 계속 & $2014-2018$ & 다자성양자 & 3 \\
\hline & $\begin{array}{l}\text { 서태평양지역 개도국 } \\
\text { 바이오의약품 평가 및 } \\
\text { 허가 기술지원 }\end{array}$ & $\begin{array}{l}\text { 서태평양지역개도국바 } \\
\text { 이오의약품평가및허가 } \\
\text { 기술지원 } \\
\text { (WHOWPRO) }\end{array}$ & EE & 80.78 & 25.00 & 계속 & $2015-2019$ & 벙양자 & 3 \\
\hline & $\begin{array}{l}\text { 서태평양지역 개도국 } \\
\text { 바이오의약품 평가 및 } \\
\text { 허가 기술지원 }\end{array}$ & $\begin{array}{l}\text { 아시아개도국전통의약 } \\
\text { 품안전관리기반구축현 } \\
\text { 지역량조사사업 } \\
\text { (WHOWPRO) }\end{array}$ & 프로젝트 & 4.40 & 1.00 & 계속 & $2016-2020$ & 다자성양자 & 3 \\
\hline & $\begin{array}{l}\text { WHO 식품 위해평가 } \\
0 \text { 등 네트워크 운영 대 } \\
\text { 응능력 향상 프로그램 }\end{array}$ & $\begin{array}{l}\text { WHO 식품안전 자문 } \\
\text { 프로그램 지원 }\end{array}$ & 프로젝트 & 2.64 & 1.32 & 신규 & $2017-2018$ & 다자성양자 & 3 \\
\hline & $\begin{array}{l}1 \text { 아시아 식품안전 당 } \\
\text { 국자 네트워크 } \\
\text { (INFOSAN)를 통한 } \\
\text { 식품안전관리 역량 제 } \\
\text { 고 }\end{array}$ & $\begin{array}{l}\text { 아시아 식품안전 당국 } \\
\text { 자 네트워크 } \\
\text { (INFOSAN)를 통한 } \\
\text { 식품안전관리 역량 제 } \\
\text { 고 }\end{array}$ & $\begin{array}{c}\text { 기타기술협 } \\
\text { 력 }\end{array}$ & 4.10 & 0.98 & 신규 & $2018-2021$ & 다자성양자 & 1 \\
\hline & $\begin{array}{l}\text { 한아세안 건강기능식 } \\
\text { 품 위생협력 }\end{array}$ & $\begin{array}{l}\text { 한아세안 건강기능식 } \\
\text { 품 위생협력 }\end{array}$ & \begin{tabular}{|c|}
$\begin{array}{c}\text { 기타기술협 } \\
\text { 력 }\end{array}$ \\
\end{tabular} & 4.86 & 1.62 & 신규 & $2018-2020$ & 양자무상 & 2 \\
\hline
\end{tabular}




\section{관세청 2018년도 ODA 예산 계획[안]}

$\square$ 총괄

(단위: 억원)

\begin{tabular}{l|c|c|c||c|c|c}
\hline \multirow{2}{*}{$\mathrm{ODA}$ 시행부처(기관) } & \multicolumn{3}{|c||}{2017} & \multicolumn{3}{c}{2018 (요구) } \\
\cline { 2 - 7 } & 양자 무상 & 다자 & 합계 & 양자 무상 & 다자 & 합계 \\
\hline 관세청 & 40.5 & 19.7 & 60.2 & 33.7 & 19.7 & 53.4 \\
\hline
\end{tabular}

※ 다자성양자는 양자에 포함

○ '18년도 ODA 시행목표

- 전자통관시스템(UNI-PASS) 수출 확대와 체계적인 초청연수 운영으로 개도국 통관환경 개선 및 글로벌 관세행정 발전을 위한 국제 기여도 제고

- 수원국의 관세행정 현대화를 통한 조세수입 증대로 경제발전 및 자립성장 원조

- UN 지속가능개발목표(SDGs) 중 ‘경제성장·글로벌 파트너십 강화’ 달성

0 주요 정책과제

- UNI-PASS 수출기반 확장 및 개도국 통관환경 개선사업 주도

- 외국 세관직원에 대한 초청연수 내실화와 체계적인 인적 네트워크 구축으로 개도국 세관행정 현대화 지원 및 해외에 관세행정 친한파 육성

- 국제개발협력과 관련된 경제성장 및 글로벌 파트너십 강화(SDGs)에 기여

- 개발컨설팅· 초청연수 등을 통한 과학기술 역량 강화에 기여

\section{유형별 분류}

(억원, \%)

\begin{tabular}{|c|c|c|c|c|c|c|c|c|c|c|c|c|}
\hline \multirow[b]{2}{*}{ 구분 } & \multirow[b]{2}{*}{ 계 } & \multirow[b]{2}{*}{ 프로 } & \multirow[b]{2}{*}{$\begin{array}{l}\text { 프로 } \\
\text { 그램 }\end{array}$} & \multirow[b]{2}{*}{$\begin{array}{l}\text { 개발 } \\
\text { 컨설팅 }\end{array}$} & \multicolumn{4}{|c|}{ 기술협력 } & \multirow{2}{*}{$\begin{array}{c}\text { 민관 } \\
\text { 협력 } \\
\text { (NGO, } \\
\text { 기업) }\end{array}$} & \multirow[b]{2}{*}{$\begin{array}{l}\text { 행정 } \\
\text { 비용 }\end{array}$} & \multirow[b]{2}{*}{ 기타 } & \multirow[b]{2}{*}{$\begin{array}{l}\text { 순수 } \\
\text { 다자* }\end{array}$} \\
\hline & & & & & $\begin{array}{l}\text { 연수 } \\
\text { 사업 }\end{array}$ & $\begin{array}{l}\text { 장학 } \\
\text { 지원 }\end{array}$ & $\begin{array}{l}\text { 봉사단 } \\
\text { 파견 }\end{array}$ & $\begin{array}{l}\text { 기타 } \\
\text { 기술 } \\
\text { 협력 }\end{array}$ & & & & \\
\hline \multirow{2}{*}{ '17년 } & 60.2 & - & - & 29.3 & 11.1 & - & - & 0.2 & - & - & - & 19.7 \\
\hline & 100 & - & - & 48.6 & 18.4 & - & - & 0.3 & - & - & - & 32.7 \\
\hline '18년 & 53.4 & - & - & 22.4 & 10.9 & - & - & 0.4 & - & $\therefore$ & - & 19.7 \\
\hline (요구) & 100 & $\cdots$ & $\begin{array}{l}\cdots \\
-\end{array}$ & 42.1 & 20.4 & - & $\begin{array}{l}\cdots \\
-\end{array}$ & 0.7 & $\begin{array}{l}\cdots \\
-\end{array}$ & - & $\begin{array}{l}\cdots \\
-\end{array}$ & 36.8 \\
\hline
\end{tabular}

* 다자성양자를 제외한 순수다자만 해당되며, 다자성양자는 사업 유형에 맞게 분류

$\square$ 총 사업 목록

\begin{tabular}{|c|c|c|c|c|c|c|c|c|c|}
\hline & 세부사업명 & 내역사업명 & 사업 유형 & $\begin{array}{c}\text { 총사업 예산 } \\
\text { (억원) }\end{array}$ & $\begin{array}{c}\text { '18년예산 } \\
\text { (억원) }\end{array}$ & $\begin{array}{l}\text { 신규/ } \\
\text { 계속 }\end{array}$ & $\begin{array}{l}\text { 총사업 } \\
\text { 기간 }\end{array}$ & $\begin{array}{c}\text { 구분 } \\
\text { (양·다자) }\end{array}$ & $\begin{array}{c}\text { SDGs } \\
\text { 목표 }\end{array}$ \\
\hline & $\begin{array}{l}\text { 개도국 관세행정 현 } \\
\text { 대화 지원(ODA) }\end{array}$ & $\begin{array}{l}\text { 개도국관세행정업무재 } \\
\text { 설계 } \\
\text { (나이지리아) }\end{array}$ & 개발컨설팅 & 7.32 & 0.50 & 신규 & $2018-2019$ & 양자무상 & 8 \\
\hline & $\begin{array}{l}\text { 개도국 관세행정 현 } \\
\text { 대화 지원(ODA) }\end{array}$ & $\begin{array}{l}\text { 개도국관세행정업무재 } \\
\text { 설계 } \\
\text { (알제리) }\end{array}$ & 개발컨설팅 & 7.32 & 7.32 & 신규 & 2018 & 양자무상 & 8 \\
\hline & $\begin{array}{l}\text { 개도국 관세행정 현 } \\
\text { 대화 지원(ODA) }\end{array}$ & $\begin{array}{l}\text { 개도국관세행정업무재 } \\
\text { 설계 } \\
\text { (피지) }\end{array}$ & 개발컨설팅 & 7.32 & 7.32 & 신규 & 2018 & 양자무상 & 8 \\
\hline
\end{tabular}




\begin{tabular}{|c|c|c|c|c|c|c|c|c|c|}
\hline & 세부사업명 & 내역사업명 & 사업 유형 & $\begin{array}{l}\text { 총사업 예산 } \\
\text { (억원) }\end{array}$ & $\begin{array}{c}\text { '18년 예산 } \\
\text { (억원) }\end{array}$ & $\begin{array}{l}\text { 신규/ } \\
\text { 계속 }\end{array}$ & $\begin{array}{l}\text { 총사업 } \\
\text { 기간 }\end{array}$ & $\begin{array}{c}\text { 구분 } \\
\text { (양·다자) }\end{array}$ & $\begin{array}{l}\text { SDGs } \\
\text { 목표 }\end{array}$ \\
\hline 4 & $\begin{array}{l}\text { 개도국 관세행정 현 } \\
\text { 대화 지원(ODA) }\end{array}$ & $\begin{array}{l}\text { 개도국관세행정업무재 } \\
\text { 설계 } \\
\text { (요르단) }\end{array}$ & 개발컨설팅 & 7.32 & 7.32 & 신규 & 2018 & 양자무상 & 8 \\
\hline 5 & $\begin{array}{l}\mathrm{AEO} \text { 무역원활화 연 } \\
\text { 수 }\end{array}$ & $\begin{array}{l}\mathrm{AEO} \text { 무역원활화 연 } \\
\text { 수 }\end{array}$ & 연수사업 & 5.83 & 5.83 & 신규 & 2018 & 양자무상 & 8 \\
\hline$\left.6\right|_{1} ^{1}$ & $\begin{array}{l}\text { IT,SW 분야 WCO } \\
\text { RTC 과정 운영 }\end{array}$ & $\begin{array}{l}\text { IT,SW 분야 WCO } \\
\text { RTC 과정 운영 }\end{array}$ & 연수사업 & 3.41 & 3.41 & 신규 & 2018 & 양자무상 & 17 \\
\hline 7 & $\begin{array}{l}\text { 한국 관세청의 선진 } \\
\text { 관세행정기법 전수 }\end{array}$ & $\begin{array}{l}\text { 한국관세청의선진관세 } \\
\text { 행정기법전수 } \\
\text { (세르비아) }\end{array}$ & 연수사업 & 0.54 & 0.54 & 신규 & 2018 & 양자무상 & 8 \\
\hline 8 & $\begin{array}{l}\text { 한국 관세청의 선진 } \\
\text { 관세행정기법 전수 }\end{array}$ & $\begin{array}{l}\text { 한국관세청의선진관세 } \\
\text { 행정기법전수 } \\
\text { (미얀마) }\end{array}$ & 연수사업 & 0.54 & 0.54 & 신규 & 2018 & 양자무상 & 8 \\
\hline 9 & $\begin{array}{l}\text { 한국 관세청의 선진 } \\
\text { 관세행정기법 전수 }\end{array}$ & $\begin{array}{l}\text { 한국관세청의선진관세 } \\
\text { 행정기법전수 } \\
\text { (태국) }\end{array}$ & 연수사업 & 0.54 & 0.54 & 신규 & 2018 & 양자무상 & 8 \\
\hline 10 & $\begin{array}{l}\text { 세관행정 현대화 워 } \\
\text { 크숍 }\end{array}$ & $\begin{array}{l}\text { 세관행정 현대화 워크 } \\
\text { 숍 }\end{array}$ & 기타기술협력 & 0.40 & 0.40 & 신규 & 2018 & 양자무상 & 8 \\
\hline 11 & $\begin{array}{l}\text { 세계관세기구(WCO) } \\
\text { 세관협력기금(CCF) }\end{array}$ & $\begin{array}{l}\text { 세계관세기구(WCO) } \\
\text { 세관협력기금(CCF) }\end{array}$ & & 19.65 & 19.65 & 계속 & $2011-2018$ & 다자 & \\
\hline
\end{tabular}




\section{통계청 2018년도 ODA 예산 계획[안]}

$\square$ 총괄

(단위: 억원)

\begin{tabular}{l|c|c|c||c|c|c}
\hline \multirow{2}{*}{ ODA 시행부처(기관) } & \multicolumn{3}{|c||}{2017} & \multicolumn{3}{c}{2018 (요구) } \\
\cline { 2 - 7 } & 양자 무상 & 다자 & 합계 & 양자 무상 & 다자 & 합계 \\
\hline 통계청 & 15.4 & - & 15.4 & 32.1 & - & 32.1 \\
\hline
\end{tabular}

* 다자성양자는 양자에 포함

○ '18년도 ODA 시행목표

- SDGs 모니터링 및 이행지원을 위한 개도국 통계역량강화

으주요 정책과제

- 통계분야 개발협력사업의 체계화 및 효율화

- 사업효과성 증진을 위한 모니터링 및 평가체계 강화

$\square$ 유형별 분류

(억원, \%)

\begin{tabular}{|c|c|c|c|c|c|c|c|c|c|c|c|c|}
\hline \multirow[b]{2}{*}{ 구분 } & \multirow[b]{2}{*}{ 계 } & \multirow[b]{2}{*}{ 프로 } & \multirow[b]{2}{*}{$\begin{array}{l}\text { 프로 } \\
\text { 그램 }\end{array}$} & \multirow[b]{2}{*}{$\begin{array}{l}\text { 개발 } \\
\text { 컨설팅 }\end{array}$} & \multicolumn{4}{|c|}{ 기술협력 } & \multirow{2}{*}{$\begin{array}{c}\text { 민관 } \\
\text { 협력 } \\
\text { (NGO, } \\
\text { 기업) }\end{array}$} & \multirow[b]{2}{*}{$\begin{array}{l}\text { 행정 } \\
\text { 비용 }\end{array}$} & \multirow[b]{2}{*}{ 기타 } & \multirow[b]{2}{*}{$\begin{array}{l}\text { 순수 } \\
\text { 다자* }\end{array}$} \\
\hline & & & & & $\begin{array}{l}\text { 연수 } \\
\text { 사업 }\end{array}$ & $\begin{array}{l}\text { 장학 } \\
\text { 지원 }\end{array}$ & $\begin{array}{l}\text { 봉사단 } \\
\text { 파견 }\end{array}$ & $\begin{array}{l}\text { 기타 } \\
\text { 기술 } \\
\text { 협력 }\end{array}$ & & & & \\
\hline \multirow{2}{*}{ '17년 } & 15.4 & 8.4 & - & 4.0 & 1.8 & - & - & - & - & - & 1.2 & - \\
\hline & 100 & 54.6 & - & 26.0 & 11.8 & - & - & - & - & - & 7.7 & - \\
\hline '18년 & 32.1 & 29.0 & - & - & 1.9 & - & - & - & - & - & 1.2 & - \\
\hline (요구) & 100 & 90.3 & $\begin{array}{l}\cdots \\
-\end{array}$ & - & 5.8 & - & - & - & - & - & 3.9 & - \\
\hline
\end{tabular}

* 다자성양자를 제외한 순수다자만 해당되며, 다자성양자는 사업 유형에 맞게 분류

$\square$ 총 사업 목록

\begin{tabular}{|c|c|c|c|c|c|c|c|c|c|}
\hline & 세부사업명 & 내역사업명 & 사업 유형 & $\begin{array}{l}\text { 총사업 예산 } \\
\text { (억원) }\end{array}$ & $\begin{array}{l}18 \text { 년예산 } \\
\text { (억원) }\end{array}$ & $\begin{array}{l}\text { 신규/ } \\
\text { 계속 }\end{array}$ & $\begin{array}{l}\text { 총사업 } \\
\text { 기간 }\end{array}$ & \begin{tabular}{|c|} 
구분 \\
(양-다자)
\end{tabular} & $\begin{array}{l}\text { SDGs } \\
\text { 목표 }\end{array}$ \\
\hline 1 & 개도국통계지원 & $\begin{array}{l}\text { 라오스 통계역량강화 } \\
\text { 사업 }\end{array}$ & 프로젝트 & 45.00 & 15.00 & 계속 & $2017-2020$ & 양자무상 & 17 \\
\hline 2 & 개도국통계지원 & $\begin{array}{l}\text { 콜롬비아 통계역량강 } \\
\text { 화사업 }\end{array}$ & 프로젝트 & 11.56 & 7.00 & 계속 & $2017-2018$ & 양자무상 & 17 \\
\hline 3 & 개도국통계지원 & $\begin{array}{l}\text { 아제르바이잔 통계역 } \\
\text { 량강화사업 }\end{array}$ & 프로젝트 & 18.70 & 7.00 & 신규 & $2018-2019$ & 양자무상 & 17 \\
\hline 4 & 개도국통계지원 & $\begin{array}{l}\text { 선진협력기관 공조 개 } \\
\text { 도국 초청연수 }\end{array}$ & 연수사업 & 1.07 & 1.07 & 신규 & 2018 & 양자무상 & 17 \\
\hline 5 & 개도국통계지원 & $\begin{array}{l}\text { UNSIAP 공조 개도국 } \\
\text { 초청연수 }\end{array}$ & 연수사업 & 0.80 & 0.80 & 신규 & 2018 & 양자무상 & 17 \\
\hline 6 & 개도국통계지원 & $\begin{array}{l}\text { UNESCAP(UNSIAP) } \\
\text { 분담금 }\end{array}$ & 기타 & 0.70 & 0.70 & 계속 & 매년('11 ) & 다자성양자 & 17 \\
\hline 7 & 개도국통계지원 & $\begin{array}{l}\text { OECD(PARIS21) 분 } \\
\text { 담금 }\end{array}$ & 기타 & 0.54 & 0.54 & 계속 & 매년('99 ) & 다자성양자 & 17 \\
\hline
\end{tabular}




\section{경찰청 2018년도 ODA 예산 계획[안]}

$\square$ 총괄

(단위: 억원)

\begin{tabular}{l|c|c|c||c|c|c}
\hline \multirow{2}{*}{$\mathrm{ODA}$ 시행부처(기관) } & \multicolumn{3}{|c||}{2017} & \multicolumn{3}{c}{2018 (요구) } \\
\cline { 2 - 7 } & 양자 무상 & 다자 & 합계 & 양자 무상 & 다자 & 합계 \\
\hline 경찰청 & 24.0 & - & 24.0 & 37.3 & - & 37.3 \\
\hline
\end{tabular}

※ 다자성양자는 양자에 포함

○ '18년도 ODA 시행목표

- 베트남 과학수사 발전을 위한 기초 인프라를 구축하고 우간다 경찰 발전을 위한 인적자원 개발을 추진해 ‘범죄로부터 안전한 사회 구현’ 지원(국제개발기 본법 제3조 제2항 2호 관련)

- 한국 경찰의 선진 치안시스템 전수를 통해 양국 경찰간 협력관계 구축 및 교류 추진, ‘더 안전한 세계’를 위한 협력 강화(국제개발기본법 제3조 제2항 관련)

이주요 정책과제

- 베트남경찰의 과학수사 역량 강화를 위한 인프라(DNA감식동) 구축

- 과학수사 제도 정착을 위한 전문가 양성(교육훈련 지원)

- 우간다경찰의 범죄예방 역량 강화를 위한 초청연수 실시

$\square$ 유형별 분류

(억원, \%)

\begin{tabular}{|c|c|c|c|c|c|c|c|c|c|c|c|c|}
\hline \multirow[b]{2}{*}{ 구분 } & \multirow[b]{2}{*}{ 계 } & \multirow[b]{2}{*}{ 프로 } & \multirow[b]{2}{*}{$\begin{array}{l}\text { 프로 } \\
\text { 그램 }\end{array}$} & \multirow[b]{2}{*}{$\begin{array}{l}\text { 개발 } \\
\text { 컨설팅 }\end{array}$} & \multicolumn{4}{|c|}{ 기술협력 } & \multirow{2}{*}{\begin{tabular}{|c|} 
민관 \\
협력 \\
(NGO, \\
기업) \\
\end{tabular}} & \multirow[b]{2}{*}{$\begin{array}{l}\text { 행정 } \\
\text { 비용 }\end{array}$} & \multirow[b]{2}{*}{ 기타 } & \multirow[b]{2}{*}{$\begin{array}{l}\text { 순수 } \\
\text { 다자* }\end{array}$} \\
\hline & & & & & $\begin{array}{l}\text { 연수 } \\
\text { 사업 }\end{array}$ & $\begin{array}{l}\text { 장학 } \\
\text { 지원 }\end{array}$ & $\begin{array}{l}\text { 봉사단 } \\
\text { 파견 }\end{array}$ & $\begin{array}{l}\text { 기타 } \\
\text { 기술 } \\
\text { 협력 }\end{array}$ & & & & \\
\hline \multirow{2}{*}{ '17년 } & 24.0 & 22.2 & - & - & 1.8 & - & - & - & - & - & - & - \\
\hline & 100 & 92.5 & $\begin{array}{l}\cdots \\
-\end{array}$ & - & 7.5 & - & - & - & - & - & - & - \\
\hline '18년 & 37.3 & 35.5 & - & - & 1.8 & - & - & - & - & - & - & - \\
\hline (요구) & 100 & 95.2 & - & - & 4.8 & - & - & - & - & - & - & - \\
\hline
\end{tabular}

* 다자성양자를 제외한 순수다자만 해당되며, 다자성양자는 사업 유형에 맞게 분류

$\square$ 총 사업 목록

\begin{tabular}{l|l|l|r|r|r|r|r|r|r}
\hline \multicolumn{1}{|c|}{ 세부사업명 } & \multicolumn{1}{|c|}{ 내역사업명 } & 사업 유형 & $\begin{array}{c}\text { 총사업 예산 } \\
\text { (억원) }\end{array}$ & $\begin{array}{c}18 \text { 년예산 } \\
\text { (억원) }\end{array}$ & $\begin{array}{l}\text { 신규/ } \\
\text { 계속 }\end{array}$ & $\begin{array}{c}\text { 총사업 } \\
\text { 기간 }\end{array}$ & $\begin{array}{c}\text { 구분 } \\
\text { (양-다자) }\end{array}$ & $\begin{array}{l}\text { SDGs } \\
\text { 목표 }\end{array}$ \\
\hline $\begin{array}{l}\text { 베트남 } \\
\text { 과학수사역량 } \\
\text { 강화사업 }\end{array}$ & $\begin{array}{l}\text { 베트남 } \\
\text { 과학수사역량 } \\
\text { 강화사업 }\end{array}$ & 프로젝트 & 61.89 & 35.51 & 계속 & $2017 \sim 2019$ & 양자무상 & 16 \\
\hline $\begin{array}{l}\text { 우간다 치안역량 } \\
\text { 강화사업 }\end{array}$ & $\begin{array}{l}\text { 우간다 치안역량 } \\
\text { 강화사업 }\end{array}$ & 연수사업 & 5.43 & 1.81 & 계속 & $2017 \sim 2019$ & 양자무상 & 16 \\
\hline
\end{tabular}




\section{문화재청 2018년도 ODA 예산 계획[안]}

$\square$ 총괄

(단위: 억원)

\begin{tabular}{l|c|c|c||c|c|c}
\hline \multirow{2}{*}{$\mathrm{ODA}$ 시행부처(기관) } & \multicolumn{3}{|c||}{2017} & \multicolumn{3}{c}{2018 (요구) } \\
\cline { 2 - 7 } & 양자 무상 & 다자 & 합계 & 양자 무상 & 다자 & 합계 \\
\hline 문화재청 & 30.4 & 0.9 & 31.3 & 42.7 & 0.1 & 42.8 \\
\hline
\end{tabular}

※ 다자성양자는 양자에 포함

○ '18년도 ODA 시행목표

- 위험에 처한 협력국의 세계유산 등 문화유산 보존 지원 및 국제기구(UNESCO, ICCROM 등) 기여를 통해 수원국의 지속가능한 발전에 기여

우주요 정책과제

- (양자)라오스, 미얀마 등 중점협력국 대상 문화재 보존관리 인프라 구축, 전문인력 양성 지 원, 기술 교류 등을 통해 협력국의 문화유산 보존관리 역량 강화에 기여

- (다자)세계유산 심사자문기구(UNESCO, ICOMOS, IUCN, ICCROM) 분담금과 신탁기금 확 대로 세계유산 관련 국제적 위상 제고 및 세계유산 등재 효율성 증대

$\square$ 유형별 분류

(억원, \%)

\begin{tabular}{|c|c|c|c|c|c|c|c|c|c|c|c|c|}
\hline \multirow[b]{2}{*}{ 구분 } & \multirow[b]{2}{*}{ 계 } & \multirow[b]{2}{*}{$\begin{array}{l}\text { 프로 } \\
\text { 젝트 }\end{array}$} & \multirow[b]{2}{*}{$\begin{array}{l}\text { 프로 } \\
\text { 르램 }\end{array}$} & \multirow[b]{2}{*}{$\begin{array}{l}\text { 개발 } \\
\text { 컨설팅 }\end{array}$} & \multicolumn{4}{|c|}{ 기술협력 } & \multirow{2}{*}{$\begin{array}{c}\text { 민관 } \\
\text { 협력 } \\
\text { (NGO, } \\
\text { 기업) }\end{array}$} & \multirow[b]{2}{*}{$\begin{array}{l}\text { 행정 } \\
\text { 비용 }\end{array}$} & \multirow[b]{2}{*}{ 기타 } & \multirow[b]{2}{*}{$\begin{array}{l}\text { 순수 } \\
\text { 다자** }\end{array}$} \\
\hline & & & & & $\begin{array}{l}\text { 연수 } \\
\text { 사업 }\end{array}$ & $\begin{array}{l}\text { 장학 } \\
\text { 지원 }\end{array}$ & $\begin{array}{l}\text { 봉사단 } \\
\text { 파견 }\end{array}$ & $\begin{array}{l}\text { 기타 } \\
\text { 기술 } \\
\text { 협력 }\end{array}$ & & & & \\
\hline \multirow{2}{*}{ '17년 } & 31.3 & - & - & - & - & - & - & 28.3 & - & - & 2.1 & 0.9 \\
\hline & 100 & - & - & - & - & - & - & 90.5 & - & - & 6.6 & 2.9 \\
\hline \multirow{2}{*}{$\begin{array}{l}\text { '18년 } \\
\text { (요구) }\end{array}$} & 42.8 & 26.6 & - & - & - & - & - & 14.1 & - & - & 2.1 & 0.1 \\
\hline & 100 & 62.1 & - & - & - & - & - & 32.8 & - & - & 4.8 & 0.3 \\
\hline
\end{tabular}

* 다자성양자를 제외한 순수다자만 해당되며, 다자성양자는 사업 유형에 맞게 분류

$\square$ 총 사업 목록

\begin{tabular}{|c|c|c|c|c|c|c|c|c|c|}
\hline & 세부사업명 & 내역사업명 & 사업 유형 & $\begin{array}{c}\text { 총사업 예산 } \\
\text { (억원) }\end{array}$ & $\begin{array}{c}\text { '18년예산 } \\
\text { (억원) }\end{array}$ & $\begin{array}{l}\text { 신규/ } \\
\text { 계속 }\end{array}$ & $\begin{array}{l}\text { 총사업 } \\
\text { 기간 }\end{array}$ & $\begin{array}{c}\text { 구분 } \\
\text { (양-다자) }\end{array}$ & $\begin{array}{l}\text { SDGs } \\
\text { 목표 }\end{array}$ \\
\hline 1 & $\begin{array}{l}\text { 협력국 세계유산 보 } \\
\text { 존관리 지원사업 }\end{array}$ & $\begin{array}{l}\text { 협력국 세계유산 보존 } \\
\text { 관리 지원(라오스) }\end{array}$ & 프로젝트 & 83.30 & 21.60 & 계속 & $2013-2020$ & 양자무상 & 11 \\
\hline 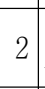 & $\begin{array}{l}\text { 협력국 세계유산 보 } \\
\text { 존관리 지원사업 }\end{array}$ & $\begin{array}{l}\text { 협력국 세계유산 보존 } \\
\text { 관리 지원(미얀마) }\end{array}$ & 프로젝트 & 18.00 & 5.00 & 계속 & $2015-2020$ & 양자무상 & 11 \\
\hline 3 & $\begin{array}{l}\text { 협력국 무형유산 보호 } \\
\text { 제도 구축지원사업 }\end{array}$ & $\begin{array}{l}\text { 협력국 무형유산 보 } \\
\text { 호제도 구축지원(라오 } \\
\text { 스) }\end{array}$ & 기타기술협력 & 2.50 & 0.50 & 계속 & $2015-2019$ & 양자무상 & 11 \\
\hline 4 & $\begin{array}{l}\text { 협ㄹㅕㅕ국 무형유산 보 } \\
\text { 호제도 구축지원사업 }\end{array}$ & $\begin{array}{l}\text { 협력국 무형유산 보호 } \\
\text { 제도 구축지원(카자 } \\
\text { 흐스탄) }\end{array}$ & 기타기술협력 & 0.50 & 0.50 & 신규 & 2018 & 양자무상 & 11 \\
\hline 5 & $\begin{array}{l}\text { 협력국 유네스코 유 } \\
\text { 산 등재역량 강화 지 } \\
\text { 원사업 }\end{array}$ & $\begin{array}{l}\text { 협력국 유네스코 유산 } \\
\text { 등재역량 강화 지원 } \\
\text { (아시아) }\end{array}$ & 기타기술협력 & 1.50 & 1.50 & 신규 & 2018 & 양자무상 & 11 \\
\hline
\end{tabular}




\begin{tabular}{|c|c|c|c|c|c|c|c|c|c|}
\hline & 세부사업명 & 내역사업명 & 사업 유형 & $\begin{array}{c}\begin{array}{c}\text { 총사업 예산 } \\
\text { (억원) }\end{array} \\
\end{array}$ & $\begin{array}{l}\text { '18년 예산 } \\
\text { (억원) }\end{array}$ & \begin{tabular}{|l|} 
신규/ \\
계속 \\
\end{tabular} & $\begin{array}{l}\text { 총사업 } \\
\text { 기간 }\end{array}$ & $\begin{array}{c}\text { 구분 } \\
\text { (양-다자) }\end{array}$ & $\begin{array}{l}\text { SDGS } \\
\text { 목표 }\end{array}$ \\
\hline 6 & $\begin{array}{l}\text { 문화재청-UNESCO아 } \\
\text { 태지역세계유산 } \\
\text { 보호를위한신탁기금 }\end{array}$ & $\begin{array}{l}\text { 문화재청-UNESCO아 } \\
\text { 태지역세계유산 } \\
\text { 보호를위한신탁기금 }\end{array}$ & 기타기술협력 & 23.00 & 4.60 & 계속 & $\begin{array}{c}2017-2021 \\
\text { (5년) }\end{array}$ & 다자성양자 & 11 \\
\hline 7 & $\begin{array}{l}\text { 문화재청-ICCROM } \\
\text { 아태지역 문화재 보존 } \\
\text { 역량 강화를 위한 신 } \\
\text { 탁기금 }\end{array}$ & $\begin{array}{l}\text { 문화재청-ICCROM } \\
\text { 아태지역 문화재 보 } \\
\text { 존역량 강화를 위한 } \\
\text { 신탁기금 }\end{array}$ & 기타기술협력 & 12.50 & 2.50 & 신규 & $\begin{array}{l}2018-2022 \\
\quad \text { (5년) } \\
* 1 \text { 차사업: } 20 \\
13-2017 \text { ( } 5 \\
\text { 년) }\end{array}$ & 다자성양자 & 11 \\
\hline 8 & $\begin{array}{l}\text { 문화재청-IUCN아태 } \\
\text { 지역주제연구사업 } \\
\text { 기여금 }\end{array}$ & $\begin{array}{l}\text { 문화재청-IUCN아태 } \\
\text { 지역주제연구사업 } \\
\text { 기여금 }\end{array}$ & 기타기술협력 & 1.50 & 0.50 & 계속 & $\begin{array}{c}2017-2019 \\
\text { (3년) }\end{array}$ & 다자성양자 & 11 \\
\hline 9 & $\begin{array}{l}\text { 문화재청-ICOMOS아 } \\
\text { 태지역주제연구 } \\
\text { 사업기여금 }\end{array}$ & $\begin{array}{l}\text { 문화재청-ICOMOS아 } \\
\text { 태지역주제연구 } \\
\text { 사업기여금 }\end{array}$ & 기타기술협력 & 1.50 & 0.50 & 계속 & $\begin{array}{c}2017-2019 \\
\text { (3년) }\end{array}$ & 다자성양자 & 11 \\
\hline 10 & $\begin{array}{l}\text { 문화재청-UNESCO무 } \\
\text { 형문화유산의지속개발 } \\
\text { 을위한역량강화사업 }\end{array}$ & $\begin{array}{l}\text { 문화재청-UNESCO무 } \\
\text { 형문화유산의지속개발 } \\
\text { 을 } \\
\text { 위한역량강화사업 }\end{array}$ & 기타기술협력 & 10.35 & 3.45 & 신규 & $\begin{array}{c}2018-2022 \\
\text { (5년) }\end{array}$ & 다자성양자 & 11 \\
\hline 11 & $\begin{array}{l}1 \text { UNESCO세계유산보 } \\
\text { 호협약의무분담금 }\end{array}$ & $\begin{array}{l}\text { UNESCO 세계유산보 } \\
\text { 호협약 의무분담금 }\end{array}$ & 기타 & & 0.48 & 계속 & 1988-계속 & 다자성양자 & 11 \\
\hline 12 & $\begin{array}{l}\text { UNESCO무형유산보 } \\
\text { 호협약 의무분담금 }\end{array}$ & $\begin{array}{l}\text { UNESCO무형유산보 } \\
\text { 호협약 의무분담금 }\end{array}$ & 기타 & & 0.48 & 계속 & 2005-계속 & 다자성양자 & 11 \\
\hline 13 & $3 \mathrm{IUCN}$ 의무 & IUCN 의무분 & & & 0.11 & 계속 & $\begin{array}{c}\text { 해당사항 } \\
\text { 없음 }\end{array}$ & 다자 & \\
\hline 14 & $4 \mathrm{ICCROM}$ 의무분담금 & ICCROM 의무분담금 & 기타 & & 1.10 & 계속 & $\begin{array}{l}\text { 해당사항 } \\
\text { 없음 }\end{array}$ & 다자성양자 & 11 \\
\hline
\end{tabular}




\section{농촌진흥청 2018년도 ODA 예산 계획[안]}

$\square$ 총괄

(단위: 억원)

\begin{tabular}{l|c|c|c||c|c|c}
\hline \multirow{2}{*}{$\mathrm{ODA}$ 시행부처(기관) } & \multicolumn{3}{|c||}{2017} & \multicolumn{3}{c}{2018 (요구) } \\
\cline { 2 - 7 } & 양자 무상 & 다자 & 합계 & 양자 무상 & 다자 & 합계 \\
\hline 농촌진흥청 & 184.9 & 3.2 & 188.1 & 244.4 & 2.8 & 247.2 \\
\hline
\end{tabular}

※ 다자성양자는 양자에 포함

유형별 분류

(억원, \%)

\begin{tabular}{|c|c|c|c|c|c|c|c|c|c|c|c|c|}
\hline \multirow[b]{2}{*}{ 구분 } & \multirow[b]{2}{*}{ 계 } & \multirow[b]{2}{*}{$\begin{array}{l}\text { 프로 } \\
\text { 젝트 }\end{array}$} & \multirow[b]{2}{*}{ 프로 } & \multirow[b]{2}{*}{$\begin{array}{l}\text { 개발 } \\
\text { 컨설팅 }\end{array}$} & \multicolumn{4}{|c|}{ 기술협력 } & \multirow{2}{*}{$\begin{array}{c}\text { 민관 } \\
\text { 협력 } \\
\text { (NGO, } \\
\text { 기업) }\end{array}$} & \multirow[b]{2}{*}{$\begin{array}{l}\text { 행정 } \\
\text { 비용 }\end{array}$} & \multirow[b]{2}{*}{ 기타 } & \multirow[b]{2}{*}{$\begin{array}{l}\text { 순수 } \\
\text { 다자** }\end{array}$} \\
\hline & & & & & $\begin{array}{l}\text { 연수 } \\
\text { 사업 }\end{array}$ & $\begin{array}{l}\text { 장항 } \\
\text { 지원 }\end{array}$ & $\begin{array}{l}\text { 봉사단 } \\
\text { 파견 }\end{array}$ & $\begin{array}{l}\text { 기타 } \\
\text { 기술 } \\
\text { 협력 }\end{array}$ & & & & \\
\hline \multirow{2}{*}{ '17년 } & 188.1 & 71.7 & $\therefore$ & 109.1 & - & - & - & 4.0 & - & - & - & 3.2 \\
\hline & 100 & 38.1 & - & 58.0 & - & - & - & 2.1 & - & - & - & 1.7 \\
\hline '18년 & 247.2 & - & 2.0 & 240.0 & - & - & - & 2.4 & - & - & - & 2.8 \\
\hline (요구) & 100 & - & 0.8 & 97.1 & - & - & - & 1.0 & - & $\ldots$ & - & 1.1 \\
\hline
\end{tabular}

* 다자성양자를 제외한 순수다자만 해당되며, 다자성양자는 사업 유형에 맞게 분류

$\square$ 총 사업 목록

\begin{tabular}{|c|c|c|c|c|c|c|c|c|c|}
\hline & 세부사업명 & 내역사업명 & 사업 유형 & $\begin{array}{l}\text { 총사업 예산 } \\
\text { (억원) }\end{array}$ & $\begin{array}{l}18 \text { 년예산 } \\
\text { (억원) }\end{array}$ & $\begin{array}{l}\text { 신규/ } \\
\text { 계속 }\end{array}$ & $\begin{array}{l}\text { 총사업 } \\
\text { 기간 }\end{array}$ & $\begin{array}{c}\text { 구분 } \\
\text { (양-다자) }\end{array}$ & $\begin{array}{l}\text { SDGS } \\
\text { 목표 }\end{array}$ \\
\hline 1 & 해외농업기술개발지원 & $\begin{array}{l}\text { 베트남 해외농업기술 } \\
\text { 개발(KOPIA) 2차 사업 }\end{array}$ & 개발컨설팅 & 40.00 & 10.00 & 계속 & $2014-2018$ & 양자무상 & 2 \\
\hline 2 & 해외농업기술개발지원 & $\begin{array}{l}\text { 캄보디아 해외농업기 } \\
\text { 술개발(KOPIA) 2차 } \\
\text { 사업 }\end{array}$ & 개발컨설팅 & 40.00 & 6.00 & 계속 & $2015-2019$ & 양자무상 & 2 \\
\hline 3 & 해외농업기술개발지원 & $\begin{array}{l}\text { 필리핀 해외농업기술 } \\
\text { 개발(KOPIA) } 2 \text { 차 사업 }\end{array}$ & 개발컨설팅 & 35.00 & 6.00 & 계속 & $2015-2019$ & 양자무상 & 2 \\
\hline 4 & 해외농업기술개발지원 & $\begin{array}{l}\text { 미얀마 해외농업기술 } \\
\text { 개발(KOPIA) 2차 사업 }\end{array}$ & 개발컨설팅 & 25.50 & 6.00 & 계속 & $2014-2018$ & 양자무상 & 2 \\
\hline 5 & 해외농업기술개발지원 & $\begin{array}{l}\text { 우즈베키스탄 해외농 } \\
\text { 업기술개발(KOPIA) } \\
2 \text { 차 사업 }\end{array}$ & 개발컨설팅 & 25.50 & 6.00 & 계속 & $2014-2018$ & 양자무상 & 2 \\
\hline 6 & 해외농업기술개발지원 & \begin{tabular}{|l|} 
태국 해외농업기술개 \\
발(KOPIA) 2차 사업
\end{tabular} & 개발컨설팅 & 20.00 & 6.00 & 계속 & $2017-2021$ & 양자무상 & 2 \\
\hline 7 & 해외농업기술개발지원 & $\begin{array}{l}\text { 스리랑카 해외농업기 } \\
\text { 술개발(KOPIA)2차 } \\
\text { 사업 }\end{array}$ & 개발컨설팅 & 40.00 & 6.00 & 계속 & $2017-2021$ & 양자무상 & 2 \\
\hline 8 & 해외농업기술개발지원 & $\begin{array}{l}\text { 케냐 해외농업기술개 } \\
\text { 발(KOPIA) 2차 사업 }\end{array}$ & 개발컨설팅 & 35.00 & 10.00 & 계속 & $2014-2018$ & 양자무상 & 2 \\
\hline 9 & 해외농업기술개발지원 & $\begin{array}{l}\text { 에티오피아 해외농업 } \\
\text { 기술개발(KOPIA) } 2 \\
\text { 차 사업 }\end{array}$ & 개발컨설팅 & 20.00 & 6.00 & 계속 & $2016-2020$ & 양자무상 & 2 \\
\hline 10 & 해외농업기술개발지원 & $\begin{array}{l}\text { 알제리 해외농업기술 } \\
\text { 개발(KOPIA) 2차 사 } \\
\text { 업 }\end{array}$ & 개발컨설팅 & 20.00 & 6.00 & 계속 & $2015-2019$ & 양자무상 & 2 \\
\hline 11 & 해외농업기술개발지원 & $\begin{array}{l}\text { 파라과이 해외농업기 } \\
\text { 술개발사업(KOPIA) } \\
2 \text { 차 사업 }\end{array}$ & 개발컨설팅 & 25.50 & 10.00 & 계속 & $2015-2019$ & 양자무상 & 2 \\
\hline
\end{tabular}




\begin{tabular}{|c|c|c|c|c|c|c|c|c|c|}
\hline & 세부사업명 & 내역사업명 & 사업 유형 & $\begin{array}{l}\begin{array}{c}\text { 총사업예산 } \\
\text { (억 원) }\end{array} \\
\end{array}$ & $\begin{array}{l}\text { '18년예산 } \\
\text { (억원) }\end{array}$ & $\begin{array}{l}\text { 신규/ } \\
\text { 계속 }\end{array}$ & $\begin{array}{l}\text { 총사업 } \\
\text { 기간 }\end{array}$ & \begin{tabular}{c|} 
구분 \\
(양.다자) \\
\end{tabular} & $\begin{array}{l}\text { SDGs } \\
\text { 목표 }\end{array}$ \\
\hline 12 & 해외농업기술개발지원 & \begin{tabular}{|l|} 
볼리비아 해외농업기 \\
술개발사업(KOPIA) \\
2 차 사업
\end{tabular} & 개발컨설팅 & 20.00 & 6.00 & 계속 & $2016-2020 \mid$ & 양자무상 & 2 \\
\hline 13 & 해외농업기술개발지원 & $\begin{array}{l}\text { 에콰도르 해외농업기 } \\
\text { 술개발사업(KOPIA) } \\
2 \text { 차 사업 }\end{array}$ & 개발컨설팅 & 28.00 & 6.00 & 계속 & $2017-2021$ & 양자무상 & 2 \\
\hline 14 & 해외농업기술개발지원 & $\begin{array}{l}\text { 우간다 해외농업기술 } \\
\text { 개발(KOPIA) } 2 \text { 차 사 } \\
\text { 업 }\end{array}$ & 개발컨설팅 & 20.00 & 6.00 & 계속 & $2017-2021$ & 양자무상 & 2 \\
\hline 15 & 해외농업기술개발지원 & 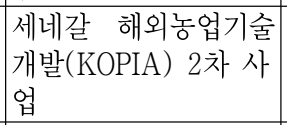 & 개발컨설팅 & 28.00 & 6.00 & 계속 & $2017-2022$ & 양자무상 & 2 \\
\hline 16 & 해외농업기술개발지원 & $\begin{array}{l}\text { 몽골 해외농업기술개 } \\
\text { 발사업(KOPIA) 사업 }\end{array}$ & 개발컨설팅 & 25.00 & 6.00 & 계속 & $2014-2018$ & 양자무상 & 2 \\
\hline 17 & 해외농업기술 & $\begin{array}{l}\text { 도미니카 해외농업기 } \\
\text { 술개발사업(KOPIA) } \\
\text { 사업 }\end{array}$ & 개발컨설팅 & 25.00 & 6.00 & 계속 & $2017-2021$ & 양자무상 & 2 \\
\hline 18 & 해외농업기술 & $\begin{array}{l}\text { 라오스 해외농업기술 } \\
\text { 개발사업(KOPIA) 사 } \\
\text { 업 }\end{array}$ & 개발컨설팅 & 25.00 & 6.00 & 계속 & $2016-2020 \mid$ & 양자무상 & 2 \\
\hline 19 & 해외농업기술개발지원 & $\begin{array}{l}\text { 짐바브웨 해외농업기 } \\
\text { 술개발사업(KOPIA) } \\
\text { 사업 }\end{array}$ & 개발컨설팅 & 25.00 & 6.00 & 계속 & $2016-2020$ & 양자무상 & 2 \\
\hline 20 & 해외농욤 & $\begin{array}{l}\begin{array}{l}\text { 니카라과 해외농업기 } \\
\text { 술개발사업(KOPIA) } \\
\text { 사업 }\end{array} \\
\end{array}$ & 개발컨설팅 & 22.00 & 6.00 & 계속 & $2017-2021$ & 양자무상 & 2 \\
\hline 21 & 해외농업기술개발지원 & $\begin{array}{l}\text { 가나 해외농업기술개 } \\
\text { 발사업(KOPIA) 사업 }\end{array}$ & 개발컨설팅 & 25.00 & 5.00 & 신규 & $2018-2022$ & 양자무상 & 2 \\
\hline 22 & 해외농업기술 & $\begin{array}{l}\text { 아시아 농식품 기술협 } \\
\text { 력 협의체 (AFACI) } \\
\text { 운영 }\end{array}$ & 개발컨설팅 & 120.00 & 23.90 & 계속 & $2015-2019$ & 양자무상 & 2 \\
\hline 23 & 해외농업기술개발지원 & $\begin{array}{l}\text { 한-아프리카 농식품 } \\
\text { 기술협력 협의체 } \\
\text { (KAFACI) 운영 }\end{array}$ & 개발컨설팅 & & 48.54 & 계속 & 11-계속 & 양자무상 & 2 \\
\hline 24 & 해외농업기술개발지원 & 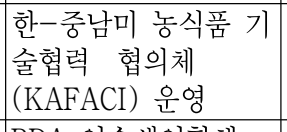 & 개발컨설팅 & & 30.52 & 계속 & 14-계속 & 양자무상 & 2 \\
\hline 25 & 해외농업기술개발지원 & $\begin{array}{l}\mathrm{RDA} \text { 연수생연합체 } \\
\text { 기술지원 사업 운영 }\end{array}$ & 기타기술협력 & 12.15 & 2.43 & 계속 & $2015-2019$ & 양자무상 & 17 \\
\hline 26 & 해외농업기술개발지원 & \begin{tabular}{|l|} 
국제기관기구분담금 \\
(아태식량비료기술센터 \\
(FFTC)분담금지원)
\end{tabular} & 프로그램 & & 0.60 & 계속 & 06-계속 & 다자성양자 & 2 \\
\hline 27 & 해외농업기술개발지원 & \begin{tabular}{|l|} 
국제기관기구분담금 \\
(세계채소센터 \\
(WorldVeg)분담금지 \\
원)
\end{tabular} & 프로그램 & & 0.60 & 계속 & 06-계속 & 다자성양자 & 2 \\
\hline 28 & 해외농업기술개발지원 & $\begin{array}{l}\text { 국제기관기구분담금 } \\
\text { (유엔/아태경제이사회 } \\
\text { 위원회CAPSA 및 } \\
\text { CSAM분담금지원) }\end{array}$ & 프로그램 & & 0.36 & 계속 & 06-계속 & 다자성양자 & 2 \\
\hline 29 & 해외농업기술개발지원 & $\begin{array}{l}\text { 국제기관기구분담금 } \\
\text { (경제개발협력기구 } \\
\text { (OECD)농약작법반및 } \\
\text { 트렉터시험코드분담금 } \\
\text { 지원) }\end{array}$ & 프로그램 & & 0.30 & 계속 & 08-계속 & 다자성양자 & 2 \\
\hline 30 & 해외농업기술개발지원 & $\begin{array}{l}\text { 국제기관기구분담금 } \\
\text { (아태농업연구기관협 } \\
\text { 의회(APAARI)분담금 } \\
\text { 지원) }\end{array}$ & 프로그램 & & 0.12 & 계속 & 01-계속 & 다자성양자 & 2 \\
\hline 31 & 해외농업기술개발지원 & \begin{tabular}{|l|} 
국제기관기구분담금 \\
(국제농업연구자문단 \\
(CGIAR)분담금)
\end{tabular} & & & 2.81 & 계속 & 11-계속 & 다자 & \\
\hline
\end{tabular}




\section{산림청 2018년도 ODA 예산 계획[안]}

$\square$ 총괄

(단위: 억원)

\begin{tabular}{l|c|c|c||c|c|c}
\hline \multirow{2}{*}{$\mathrm{ODA}$ 시행부처(기관) } & \multicolumn{3}{|c||}{2017} & \multicolumn{3}{c}{2018 (요구) } \\
\cline { 2 - 7 } & 양자 무상 & 다자 & 합계 & 양자 무상 & 다자 & 합계 \\
\hline 산림청 & 136.9 & 3.0 & 139.9 & 143.6 & 3.0 & 146.6 \\
\hline
\end{tabular}

※ 다자성양자는 양자에 포함

○ '18년도 ODA 시행목표

- 개도국의 삶의 질 향상 기여 및 산림협력 강화

이주요 정책과제

- 개도국과의 산림협력 사업 지속 추진

- 국제협력 대응사업 지속 추진으로 토지 황폐화 및 사막화 방지에 기여

$\square$ 유형별 분류

(억원, \%)

\begin{tabular}{|c|c|c|c|c|c|c|c|c|c|c|c|c|}
\hline \multirow[b]{2}{*}{ 구분 } & \multirow[b]{2}{*}{ 계 } & \multirow[b]{2}{*}{ 프로 } & \multirow[b]{2}{*}{$\begin{array}{l}\text { 프로 } \\
\text { 그램 }\end{array}$} & \multirow[b]{2}{*}{$\begin{array}{l}\text { 개발 } \\
\text { 컨설팅 }\end{array}$} & \multicolumn{4}{|c|}{ 기술협력 } & \multirow{2}{*}{\begin{tabular}{|c} 
민관 \\
협력 \\
(NGO, \\
기업) \\
\end{tabular}} & \multirow[b]{2}{*}{$\begin{array}{l}\text { 행정 } \\
\text { 비용 }\end{array}$} & \multirow[b]{2}{*}{ 기타 } & \multirow[b]{2}{*}{$\begin{array}{l}\text { 순수 } \\
\text { 다자* }\end{array}$} \\
\hline & & & & & $\begin{array}{l}\text { 연수 } \\
\text { 사업 }\end{array}$ & $\begin{array}{l}\text { 장학 } \\
\text { 지원 }\end{array}$ & $\begin{array}{l}\text { 봉사단 } \\
\text { 파견 }\end{array}$ & $\begin{array}{l}\text { 기타 } \\
\text { 기술 } \\
\text { 협력 }\end{array}$ & & & & \\
\hline \multirow{2}{*}{ '17년 } & 139.9 & 130.5 & - & 6.4 & - & - & - & - & - & - & - & 3.0 \\
\hline & 100 & 93.3 & - & 4.6 & - & - & - & - & - & - & - & 2.1 \\
\hline '18년 & 146.6 & 139.0 & - & - & 4.6 & - & - & - & - & - & - & 3.0 \\
\hline (요구) & 100 & 94.8 & - & - & 3.2 & - & - & - & $\begin{array}{l}\cdots \\
-\end{array}$ & - & - & 2.0 \\
\hline
\end{tabular}

* 다자성양자를 제외한 순수다자만 해당되며, 다자성양자는 사업 유형에 맞게 분류

$\square$ 총 사업 목록

\begin{tabular}{|c|c|c|c|c|c|c|c|c|c|}
\hline & 세부사업명 & 내역사업명 & 사업 유형 & $\begin{array}{c}\text { 총사업 예산 } \\
\text { (억원) }\end{array}$ & $\begin{array}{l}\text { '18년예산 } \\
\text { (억원) }\end{array}$ & $\begin{array}{l}\text { 신규/ } \\
\text { 계속 }\end{array}$ & $\begin{array}{l}\text { 총사업 } \\
\text { 기간 }\end{array}$ & $\begin{array}{c}\text { 구분 } \\
\text { (양-다자) }\end{array}$ & $\begin{array}{l}\mathrm{SDGS} \\
\text { 목표 }\end{array}$ \\
\hline 1 & $\begin{array}{l}\text { 국제산림협력 } \\
\text { 공적개발원조 } \\
\text { (ODA) }\end{array}$ & $\begin{array}{l}\text { 몽골그린벨트 조림사 } \\
\text { 업 }\end{array}$ & 프로젝트 & 100.35 & 20.07 & 계속 & $2017-2021$ & 양자무상 & 15 \\
\hline 2 & $\begin{array}{l}\text { 국제산림협력 } \\
\text { 공적개발원조 } \\
\text { (ODA) }\end{array}$ & $\begin{array}{l}\text { 민간 사막화방지 조림 } \\
\text { 지원 사업 }\end{array}$ & 프로젝트 & 59.73 & 5.00 & 계속 & $2007-2021$ & 양자무상 & 15 \\
\hline 3 & $\begin{array}{l}\text { 국제산림협력 } \\
\text { 공적개발원조 } \\
\text { (ODA) }\end{array}$ & $\begin{array}{l}\text { 개도국 열대림의 지속 } \\
\text { 가능한 관리 및 이용 } \\
\text { 을 위한 기술지원 }\end{array}$ & 프로젝트 & 77.75 & 6.40 & 계속 & $2009-2021$ & 양자무상 & 13 \\
\hline 4 & $\begin{array}{l}\text { 국제산림협력 } \\
\text { 공적개발원조 } \\
\text { (ODA) }\end{array}$ & $\begin{array}{l}\text { 한-인도네시아 산림 } \\
\text { 휴양 및 생태관광 협 } \\
\text { 력사업 }\end{array}$ & 프로젝트 & 27.00 & 6.20 & 계속 & $2015-2018$ & 양자무상 & 15 \\
\hline 5 & $\begin{array}{l}\text { 국제산림협력 } \\
\text { 공적개발원조 } \\
\text { (ODA) }\end{array}$ & $\begin{array}{l}\text { 메콩강유역 산림협력 } \\
\text { 센터 운영 }\end{array}$ & 프로젝트 & 21.00 & 5.00 & 계속 & $2016-2020$ & 양자무상 & 13 \\
\hline 6 & $\begin{array}{l}\text { 국제산림협력 } \\
\text { 공적개발원조 } \\
\text { (ODA) }\end{array}$ & $\begin{array}{l}\text { 유라시아 산림 협력 } \\
\text { 사업(카자흐스탄) }\end{array}$ & 프로젝트 & 32.24 & 8.62 & 계속 & $2016-2018$ & 양자무상 & 13 \\
\hline
\end{tabular}




\begin{tabular}{|c|c|c|c|c|c|c|c|c|c|}
\hline & 세부사업명 & 내역사업명 & 사업 유형 & $\begin{array}{c}\text { 총사업 예산 } \\
\text { (억원) }\end{array}$ & $\begin{array}{c}\text { '18년예산 } \\
\text { (억원) }\end{array}$ & $\begin{array}{l}\text { 신규/ } \\
\text { 계속 }\end{array}$ & $\begin{array}{l}\text { 총사업 } \\
\text { 기간 }\end{array}$ & $\begin{array}{c}\text { 구분 } \\
\text { (양-다자) }\end{array}$ & $\begin{array}{l}\text { SDGS } \\
\text { 목표 }\end{array}$ \\
\hline 7 & $\begin{array}{l}\text { 국제산림협력 } \\
\text { 공적개발원조 } \\
\text { (ODA) }\end{array}$ & $\begin{array}{l}\text { 아프리카 지속가능한 } \\
\text { 산림관리이용증진 과 } \\
\text { 정 }\end{array}$ & 연수사업 & 18.56 & 4.64 & 신규 & $2018-2021$ & 양자무상 & 4 \\
\hline 8 & $\begin{array}{l}\text { 국제산림협력 } \\
\text { 공적개발원조 } \\
\text { (ODA) }\end{array}$ & $\begin{array}{l}\text { 창원이니셔티브이행 } \\
\text { (UNCCD) }\end{array}$ & 프로젝트 & 355.00 & 20.00 & 계속 & $2012-2030$ & 다자성양자 & 15 \\
\hline 9 & $\begin{array}{l}\text { 국제산림협력 } \\
\text { 공적개발원조 } \\
\text { (ODA) }\end{array}$ & FAO 협력사업 & 프로젝트 & 42.00 & 3.00 & 계속 & $2011-2024$ & 다자성양자 & 15 \\
\hline 10 & $\begin{array}{l}\text { 국제산림협력 } \\
\text { 공적개발원조 } \\
\text { (ODA) }\end{array}$ & $\begin{array}{l}\text { 산림생태계복원 이니 } \\
\text { 셔티브 이행 }\end{array}$ & 프로젝트 & 36.32 & 7.00 & 계속 & $2015-2020$ & 다자성양자 & 15 \\
\hline 11 & $\begin{array}{l}\text { 국제산림협력 } \\
\text { 공적개발원조 } \\
\text { (ODA) }\end{array}$ & $\begin{array}{l}\text { 아시아산림협력기구 } \\
\text { 협력사업 }\end{array}$ & 프로젝트 & 600.00 & 51.00 & 계속 & $2012-2025$ & 다자성양자 & 15 \\
\hline 12 & $\begin{array}{l}\text { 국제산림협력 } \\
\text { 공적개발원조 } \\
\text { (ODA) }\end{array}$ & $\begin{array}{l}\text { 국제열대목재기구 } \\
\text { (ITTO) 사업부담금 }\end{array}$ & 프로젝트 & 20.00 & 4.10 & 계속 & $2016-2020$ & 다자성양자 & 13 \\
\hline 13 & $\begin{array}{l}\text { 국제산림협력 } \\
\text { 공적개발원조 } \\
\text { (ODA) }\end{array}$ & $\begin{array}{l}\text { 세계자연보전연맹 } \\
\text { (IUCN) 국제부담금 }\end{array}$ & 프로젝트 & & 0.11 & 계속 & 2011-계속 & 다자성양자 & 13 \\
\hline 14 & $\begin{array}{l}\text { 국제산림협력 } \\
\text { 공적개발원조 } \\
\text { (ODA) }\end{array}$ & $\begin{array}{l}\text { 국제임업연구센터 } \\
\text { (CIFOR) } \\
\text { 부담금 }\end{array}$ & 프로젝트 & 13.60 & 2.50 & 계속 & $2017-2021$ & 다자성양자 & 15 \\
\hline 15 & $\begin{array}{l}\text { 국제산림협력 } \\
\text { 공적개발원조 } \\
\text { (ODA) }\end{array}$ & $\begin{array}{l}\text { 국제열대목재기구 } \\
\text { (ITTO) 의무분담금 }\end{array}$ & & & 3.00 & 계속 & 2006-계속 & 다자 & \\
\hline
\end{tabular}




\section{중소기업청 2018년도 ODA 예산 계획[안]}

$\square$ 총괄

(단위: 억원)

\begin{tabular}{l|c|c|c||c|c|c}
\hline \multirow{2}{*}{$\mathrm{ODA}$ 시행부처(기관) } & \multicolumn{3}{|c||}{2017} & \multicolumn{3}{c}{2018 (요구) } \\
\cline { 2 - 7 } & 양자 무상 & 다자 & 합계 & 양자 무상 & 다자 & 합계 \\
\hline 중소기업청 & - & - & - & 9.5 & - & 9.5 \\
\hline
\end{tabular}

※ 다자성양자는 양자에 포함

○ '18년도 ODA 시행목표

- 최빈국 중소기업의 전자 상거래 및 글로벌 기준의 수출 품질관리를 지원하여 양질의 일자리 창출 및 경제성장 유도

우주요 정책과제

- 최빈국 수공예품·패션 생산업자의 전자 상거래 지원

- 개도국 및 최빈국 중소기업의 수출 품질관리 역량 강화를 위한 온라인 웹 기반 플랫폼 개발 및 품질관리 전문가 양성

$\square$ 유형별 분류

(억 원, \%)

\begin{tabular}{|c|c|c|c|c|c|c|c|c|c|c|c|c|}
\hline \multirow[b]{2}{*}{ 구분 } & \multirow[b]{2}{*}{ 계 } & \multirow[b]{2}{*}{$\begin{array}{l}\text { 프로 } \\
\text { 젝트 }\end{array}$} & \multirow[b]{2}{*}{$\begin{array}{l}\text { 프로 } \\
\text { 그램 }\end{array}$} & \multirow[b]{2}{*}{$\begin{array}{l}\text { 개발 } \\
\text { 컨설팅 }\end{array}$} & \multicolumn{4}{|c|}{ 기술협력 } & \multirow{2}{*}{$\begin{array}{c}\text { 민관 } \\
\text { 협력 } \\
\text { (NGO, } \\
\text { 기업) }\end{array}$} & \multirow[b]{2}{*}{$\begin{array}{l}\text { 행정 } \\
\text { 비용 }\end{array}$} & \multirow[b]{2}{*}{ 기타 } & \multirow[b]{2}{*}{$\begin{array}{l}\text { 순수 } \\
\text { 다자* }\end{array}$} \\
\hline & & & & & 연수 & $\begin{array}{l}\text { 장학 } \\
\text { 지원 }\end{array}$ & $\begin{array}{l}\text { 봉사단 } \\
\text { 파견 }\end{array}$ & $\begin{array}{l}\text { 기타 } \\
\text { 기술 } \\
\text { 협력 }\end{array}$ & & & & \\
\hline \multirow{2}{*}{ '17년 } & - & - & - & - & - & - & - & - & - & 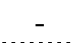 & - & - \\
\hline & - & - & - & - & - & - & - & - & $\begin{array}{c}\cdots \\
-\end{array}$ & - & - & - \\
\hline '18년 & 9.5 & 9.5 & - & - & - & - & - & - & - & - & - & - \\
\hline (요구) & 100 & 100 & - & - & - & - & - & - & - & - & - & - \\
\hline
\end{tabular}

* 다자성양자를 제외한 순수다자만 해당되며, 다자성양자는 사업 유형에 맞게 분류

$\square$ 총 사업 목록

\begin{tabular}{|c|c|c|c|c|c|c|c|c|c|}
\hline & 세부사업명 & 내역사업명 & 사업 유형 & $\begin{array}{c}\text { 총사업 예산 } \\
\text { (억원) }\end{array}$ & $\begin{array}{c}\text { '18년예산 } \\
\text { (억원) }\end{array}$ & $\begin{array}{l}\text { 신규/ } \\
\text { 계속 }\end{array}$ & $\begin{array}{l}\text { 총사업 } \\
\text { 기간 }\end{array}$ & $\begin{array}{c}\text { 구분 } \\
\text { (양-다자) }\end{array}$ & $\begin{array}{c}\mathrm{SDGS} \\
\text { 목표 }\end{array}$ \\
\hline 1 & 최빈국 중소기업 지원 & $\begin{array}{l}\text { 최빈국 수공예품 및 } \\
\text { 패션 생산업자의 전자 } \\
\text { 상거래 지원(네팔, 캄보 } \\
\text { 디아) }\end{array}$ & 프로젝트 & 6.89 & 3.61 & 신규 & $2018-2019$ & 다자성양자 & 8 \\
\hline 2 & 최빈국 중소기업 지원 & $\begin{array}{l}\text { 개도국 및 최빈국 중소 } \\
\text { 기업의 수출 품질관리 } \\
\text { 年량 강화(7개 개도국, } \\
\text { 미정) }\end{array}$ & 프로젝트 & 11.49 & 5.91 & 신규 & $2018-2019$ & 다자성양자 & 8 \\
\hline
\end{tabular}




\section{특허청 2018년도 ODA 예산 계획[안]}

$\square$ 총괄

(단위: 억원)

\begin{tabular}{l|c|c|c||c|c|c}
\hline \multirow{2}{*}{ ODA 시행부처(기관) } & \multicolumn{3}{|c||}{2017} & \multicolumn{3}{c}{2018 (요구) } \\
\cline { 2 - 7 } & 양자 무상 & 다자 & 합계 & 양자 무상 & 다자 & 합계 \\
\hline 특허청 & 17.2 & 0.1 & 17.3 & 18.0 & 0.1 & 18.1 \\
\hline
\end{tabular}

※ 다자성양자는 양자에 포함

○ '18년도 ODA 시행목표

- 최빈국, 개도국의 삶의 질 향상과 지속가능한 경제 발전 촉진을 위한 지식 재산권의 활용 확산 강화

우주요 정책과제

- 특허청의 장점을 활용하여 차별화되는 ODA 정책 구현 추진

- ODA 사업간 연계를 강화하여 사업의 효과성 제고

유형별 분류

(억원, \%)

\begin{tabular}{|c|c|c|c|c|c|c|c|c|c|c|c|c|}
\hline \multirow[b]{2}{*}{ 구분 } & \multirow[b]{2}{*}{ 계 } & \multirow[b]{2}{*}{ 프로 } & \multirow[b]{2}{*}{$\begin{array}{l}\text { 프로 } \\
\text { 그램 }\end{array}$} & \multirow[b]{2}{*}{$\begin{array}{l}\text { 개발 } \\
\text { 컨설팅 }\end{array}$} & \multicolumn{4}{|c|}{ 기술협력 } & \multirow{2}{*}{$\begin{array}{c}\text { 민관 } \\
\text { 협력 } \\
\text { (NGO, } \\
\text { 기업) }\end{array}$} & \multirow[b]{2}{*}{$\begin{array}{l}\text { 행정 } \\
\text { 비용 }\end{array}$} & \multirow[b]{2}{*}{ 기타 } & \multirow[b]{2}{*}{$\begin{array}{l}\text { 순수 } \\
\text { 다자* }\end{array}$} \\
\hline & & & & & $\begin{array}{l}\text { 연수 } \\
\text { 사업 }\end{array}$ & $\begin{array}{l}\text { 장학 } \\
\text { 지원 }\end{array}$ & $\begin{array}{l}\text { 봉사단 } \\
\text { 파견 }\end{array}$ & $\begin{array}{l}\text { 기타 } \\
\text { 기술 } \\
\text { 협력 }\end{array}$ & & & & \\
\hline \multirow{2}{*}{ '17년 } & 17.3 & 4.7 & - & - & - & - & - & 12.5 & - & - & - & 0.1 \\
\hline & 100 & 27.1 & - & - & - & - & - & 72.2 & - & - & - & 0.7 \\
\hline '18년 & 18.1 & 6.0 & - & - & 2.0 & - & - & 10.0 & - & - & - & 0.1 \\
\hline (요구) & 100 & 33.1 & $\begin{array}{l}\cdots \\
-\end{array}$ & $\cdots$ & 11 & - & $\begin{array}{l}\cdots \\
-\end{array}$ & 55.2 & $\begin{array}{l}\cdots \\
-\end{array}$ & $\begin{array}{l}\cdots \\
-\end{array}$ & - & 0.6 \\
\hline
\end{tabular}

* 다자성양자를 제외한 순수다자만 해당되며, 다자성양자는 사업 유형에 맞게 분류

$\square$ 총 사업 목록

\begin{tabular}{|c|c|c|c|c|c|c|c|c|c|}
\hline & 세부사업명 & 내역사업명 & 사업 유형 & $\begin{array}{l}\text { 총사업예산 } \\
\text { (억원) }\end{array}$ & $\begin{array}{l}\text { '18년 예산 } \\
\text { (억원) }\end{array}$ & $\begin{array}{l}\text { 신규/ } \\
\text { 계속 }\end{array}$ & $\begin{array}{l}\text { 총사업 } \\
\text { 기간 }\end{array}$ & \begin{tabular}{|c|} 
구분 \\
(양·다자)
\end{tabular} & $\begin{array}{l}\mathrm{SDGS} \\
\text { 목표 }\end{array}$ \\
\hline 1 & 국제지식재산나눔 & $\begin{array}{l}\text { 국제지식재산나눔_몽 } \\
\text { 골 }\end{array}$ & 프로젝트 & 3.00 & 3.00 & 신규 & $\begin{array}{l}\text { '18년도(단 } \\
\text { 년도) }\end{array}$ & 양자무상 & 2 \\
\hline 2 & 국제지식재산나눔 & $\begin{array}{l}\text { 국제지식재산나눔_베 } \\
\text { 트남 }\end{array}$ & 프로젝트 & 3.00 & 3.00 & 신규 & $\begin{array}{c}\text { '18년도(단 } \\
\text { 년도) }\end{array}$ & 양자무상 & 1 \\
\hline 3 & 국제지식재산나눔 & $\begin{array}{l}\text { 국제지식재산나눔_인 } \\
\text { 도네시아 }\end{array}$ & 연수사업 & 2.00 & 2.00 & 신규 & $\begin{array}{c}\text { '18년도(단 } \\
\text { 년도) }\end{array}$ & 양자무상 & 1 \\
\hline 4 & WIPO 국제분담금 & WIPO 한국신탁기금 & 기타기술협력 & 10.00 & 10.00 & 계속 & $\begin{array}{c}\text { '18년도(단 } \\
\text { 년도) }\end{array}$ & 다자성양자 & 8 \\
\hline 5 & WIPO 국제분담금 & 의무분담금 & & 4.02 & 0.12 & 계속 & $\begin{array}{c}\text { '18년도(단 } \\
\text { 년도) }\end{array}$ & 다자 & \\
\hline
\end{tabular}




\section{기상청 2018년도 ODA 예산 계획[안]}

$\square$ 총괄

(단위: 억원)

\begin{tabular}{l|c|c|c||c|c|c}
\hline \multirow{2}{*}{$\mathrm{ODA}$ 시행부처(기관) } & \multicolumn{3}{|c||}{2017} & \multicolumn{3}{c}{2018 (요구) } \\
\cline { 2 - 7 } & 양자 무상 & 다자 & 합계 & 양자 무상 & 다자 & 합계 \\
\hline 기상청 & 27.6 & 0.7 & 28.3 & 35.4 & 0.7 & 36.1 \\
\hline
\end{tabular}

※ 다자성양자는 양자에 포함

○ '18년도 ODA 시행목표

- 사업 추진 체계 내실화를 통한 자연재해 및 기후변화 대응에 기여

으주요 정책과제

- SDGs 해당 목표 : (13) 기후변화 대응

$\square$ 유형별 분류

(억원, \%)

\begin{tabular}{|c|c|c|c|c|c|c|c|c|c|c|c|c|}
\hline \multirow[b]{2}{*}{ 구분 } & \multirow[b]{2}{*}{ 계 } & \multirow[b]{2}{*}{$\begin{array}{l}\text { 프로 } \\
\text { 젝트 }\end{array}$} & \multirow[b]{2}{*}{$\begin{array}{l}\text { 프로 } \\
\text { 르램 }\end{array}$} & \multirow[b]{2}{*}{$\begin{array}{l}\text { 개발 } \\
\text { 컨설팅 }\end{array}$} & \multicolumn{4}{|c|}{ 기술협력 } & \multirow{2}{*}{$\begin{array}{c}\text { 민관 } \\
\text { 협력 } \\
\text { (NGO, } \\
\text { 기업) }\end{array}$} & \multirow[b]{2}{*}{$\begin{array}{l}\text { 행정 } \\
\text { 비용 }\end{array}$} & \multirow[b]{2}{*}{ 기타 } & \multirow[b]{2}{*}{$\begin{array}{l}\text { 순수 } \\
\text { 다자* }\end{array}$} \\
\hline & & & & & $\begin{array}{l}\text { 연수 } \\
\text { 사업 }\end{array}$ & $\begin{array}{l}\text { 장항 } \\
\text { 지원 }\end{array}$ & $\begin{array}{l}\text { 봉사단 } \\
\text { 파견 }\end{array}$ & $\begin{array}{l}\text { 기타 } \\
\text { 기수룰 } \\
\text { 협력 }\end{array}$ & & & & \\
\hline , 17너 & 28.3 & 25.2 & - & - & 2.0 & - & 0.5 & - & - & - & - & 0.7 \\
\hline $1 / 14$ & 100 & 88.9 & - & - & 7.0 & - & 1.7 & - & - & - & - & 2.4 \\
\hline '18년 & 36.1 & 33.5 & - & - & 2.0 & - & - & - & - & - & - & 0.7 \\
\hline (요구) & 100 & 92.6 & $\because$ & - & 5.5 & - & - & $\because-$ & - & - & - & 1.9 \\
\hline
\end{tabular}

* 다자성양자를 제외한 순수다자만 해당되며, 다자성양자는 사업 유형에 맞게 분류

$\square$ 총 사업 목록

\begin{tabular}{|c|c|c|c|c|c|c|c|c|c|}
\hline & 세부사업명 & 내역사업명 & 사업 유형 & $\begin{array}{c}\text { 총사업 예산 } \\
\text { (억원) }\end{array}$ & $\begin{array}{l}\text { '18년예산 } \\
\text { (억원) }\end{array}$ & $\begin{array}{l}\text { 신규/ } \\
\text { 계속 }\end{array}$ & $\begin{array}{l}\text { 총사업 } \\
\text { 기간 }\end{array}$ & $\begin{array}{c}\text { 구분 } \\
\text { (양-다자) }\end{array}$ & $\begin{array}{l}\text { SDGS } \\
\text { 목표 }\end{array}$ \\
\hline 1 & $\begin{array}{l}\text { 개도국 기상·기후업 } \\
\text { 무 수행기반 구축·운 } \\
\text { 영 지원(ODA) }\end{array}$ & $\begin{array}{l}\text { 미얀마 기상재해감시 } \\
\text { 시스템 현대화 사업 }\end{array}$ & 프로젝트 & 39.58 & 16.80 & 계속 & '17 '19 & 양자무상 & 13 \\
\hline 2 & $\begin{array}{l}\text { 개도국 기상·기후업 } \\
\text { 무 수행기반 구축·운 } \\
\text { 영 지원(ODA) }\end{array}$ & $\begin{array}{l}\text { 몽골 자동기상관측시 } \\
\text { 스템 구축 사업 }\end{array}$ & 프로젝트 & 25.84 & 11.36 & 계속 & '17 '19 & 양자무상 & 13 \\
\hline 3 & $\begin{array}{l}\text { 개도국 기상·기후업 } \\
\text { 무 수행기반 구축·운 } \\
\text { 영 지원(ODA) }\end{array}$ & $\begin{array}{l}\text { 방글라데시 천리안위 } \\
\text { 성 수신·분석시스템 } \\
\text { 활용 지원 }\end{array}$ & 프로젝트 & 12.50 & 0.60 & 신규 & '18 '20 & 양자무상 & 13 \\
\hline 4 & $\begin{array}{l}\text { 개도국 기상·기후업 } \\
\text { 무 수행기반 구축·운 } \\
\text { 영 지원(ODA) }\end{array}$ & $\begin{array}{l}\text { 피지 통합해안범람예 } \\
\text { 보시스템 구축시범사 } \\
\text { 업(CIFDP) }\end{array}$ & 프로젝트 & 13.80 & 4.70 & 계속 & '16 '19 & 다자성양자 & 13 \\
\hline 5 & $\begin{array}{l}\text { 개도국 기상·기후업 } \\
\text { 무 수행기반 구축·운 } \\
\text { 영 지원(ODA) }\end{array}$ & $\begin{array}{l}\text { 외국인 기상예보관 과 } \\
\text { 정 }\end{array}$ & 연수사업 & 6.00 & 0.99 & 신규 & '15 '18 & 양자무상 & 13 \\
\hline 6 & $\begin{array}{l}\text { 개도국 기상·기후업 } \\
\text { 무 수행기반 구축·운 } \\
\text { 영 지원(ODA) }\end{array}$ & $\begin{array}{l}\text { 외국인 기상레이더 자 } \\
\text { 료활용능력 향상과정 }\end{array}$ & 연수사업 & 6.00 & 0.99 & 신규 & '15 '18 & 양자무상 & 13 \\
\hline 7 & $\begin{array}{l}\text { 개도국 기상·기후업 } \\
\text { 무 수행기반 구축·운 } \\
\text { 영 지원(ODA) }\end{array}$ & WMO 국가분담금 & & & 0.69 & 계속 & '03 계속 & 다자 & \\
\hline
\end{tabular}




\section{헌법재판소 2018년도 ODA 예산 계획(안)}

$\square$ 총괄

(단위: 억원)

\begin{tabular}{l|c|c|c||c|c|c}
\hline \multirow{2}{*}{$\mathrm{ODA}$ 시행부처(기관) } & \multicolumn{3}{|c||}{2017} & \multicolumn{3}{c}{2018 (요구) } \\
\cline { 2 - 7 } & 양자 무상 & 다자 & 합계 & 양자 무상 & 다자 & 합계 \\
\hline 헌법재판소 & 0.4 & - & 0.4 & 0.6 & - & 0.6 \\
\hline
\end{tabular}

※ 다자성양자는 양자에 포함

○ '18년도 ODA 시행목표

- 민주주의 및 평화·제도 구축 지원

$\square$ 유형별 분류

(억원, \%)

\begin{tabular}{|c|c|c|c|c|c|c|c|c|c|c|c|c|}
\hline \multirow[b]{2}{*}{ 구분 } & \multirow[b]{2}{*}{ 계 } & \multirow[b]{2}{*}{$\begin{array}{l}\text { 프로 } \\
\text { 젝트 }\end{array}$} & \multirow[b]{2}{*}{$\begin{array}{l}\text { 프로 } \\
\text { 그램 }\end{array}$} & \multirow[b]{2}{*}{$\begin{array}{l}\text { 개발 } \\
\text { 컨설팅 }\end{array}$} & \multicolumn{4}{|c|}{ 기술협력 } & \multirow{2}{*}{$\begin{array}{c}\text { 민관 } \\
\text { 협력 } \\
\text { (NGO, } \\
\text { 기업) }\end{array}$} & \multirow[b]{2}{*}{$\begin{array}{l}\text { 행정 } \\
\text { 비용 }\end{array}$} & \multirow[b]{2}{*}{ 기타 } & \multirow[b]{2}{*}{$\begin{array}{l}\text { 순수 } \\
\text { 다자* }\end{array}$} \\
\hline & & & & & $\begin{array}{l}\text { 연수 } \\
\text { 사업 }\end{array}$ & $\begin{array}{l}\text { 장학 } \\
\text { 지원 }\end{array}$ & $\begin{array}{l}\text { 봉사단 } \\
\text { 파견 }\end{array}$ & $\begin{array}{l}\text { 기타 } \\
\text { 기술 } \\
\text { 협력 }\end{array}$ & & & & \\
\hline \multirow{2}{*}{ '17년 } & 0.4 & - & - & - & 0.4 & - & - & - & - & - & - & - \\
\hline & 100 & - & - & - & 100 & - & - & - & - & - & - & - \\
\hline '18년 & 0.6 & - & - & - & 0.6 & - & - & - & - & - & - & - \\
\hline (요구) & 100 & $\cdots$ & - & $\cdots$ & 100 & - & - & - & $\begin{array}{l}\cdots \\
-\end{array}$ & - & - & $\begin{array}{l}\cdots \\
-\end{array}$ \\
\hline
\end{tabular}

* 다자성양자를 제외한 순수다자만 해당되며, 다자성양자는 사업 유형에 맞게 분류

총 사업 목록

\begin{tabular}{l|l|l|r|r|r|r|r|r|r}
\hline & \multicolumn{1}{|c|}{ 세부사업명 } & \multicolumn{1}{|c|}{ 내역사업명 } & 사업 유형 & $\begin{array}{c}\text { 총사업 예산 } \\
\text { (억원) }\end{array}$ & $\begin{array}{c}18 \text { 년예산 } \\
\text { (억원) }\end{array}$ & $\begin{array}{c}\text { 신규/ } \\
\text { 계속 }\end{array}$ & $\begin{array}{c}\text { 총사업 } \\
\text { 기간 }\end{array}$ & $\begin{array}{c}\text { 구분 } \\
\text { (양-다자) }\end{array}$ & $\begin{array}{c}\text { SDGs } \\
\text { 목표 }\end{array}$ \\
\hline \multirow{2}{*}{$\begin{array}{l}\text { 헌법재판연구원 } \\
\text { 운영지원 }\end{array}$} & $\begin{array}{l}\text { 개발도상국 등 } \\
\text { 헌법재판기관 } \\
\text { 초청사업 }\end{array}$ & 연수사업 & 0.57 & 0.57 & 신규 & 2018 & 양자무상 & 16 \\
\hline
\end{tabular}


$\square$ 총괄

(단위: 억원)

\begin{tabular}{l|c|c|c||c|c|c}
\hline \multirow{2}{*}{$\mathrm{ODA}$ 시행부처(기관) } & \multicolumn{3}{|c||}{2017} & \multicolumn{3}{c}{2018 (요구) } \\
\cline { 2 - 7 } & 양자 무상 & 다자 & 합계 & 양자 무상 & 다자 & 합계 \\
\hline 공정거래위원회 & 1.5 & - & 1.5 & 1.6 & - & 1.6 \\
\hline
\end{tabular}

※ 다자성양자는 양자에 포함

○ '18년도 ODA 시행목표

- 개도국의 경쟁법 집행역량 강화 및 역내 경쟁문화 확산.발전 도모에 기여

으주요 정책과제

- 개도국 및 국제기구와의 경쟁 분야 협력 및 엮량 강화 지원

$\square$ 유형별 분류

(억 원, \%)

\begin{tabular}{|c|c|c|c|c|c|c|c|c|c|c|c|c|}
\hline \multirow[b]{2}{*}{ 구분 } & \multirow[b]{2}{*}{ 계 } & \multirow[b]{2}{*}{ 프로 } & \multirow[b]{2}{*}{$\begin{array}{l}\text { 프로 } \\
\text { 그램 }\end{array}$} & \multirow[b]{2}{*}{$\begin{array}{l}\text { 개발 } \\
\text { 컨설팅 }\end{array}$} & \multicolumn{4}{|c|}{ 기술협력 } & \multirow{2}{*}{$\begin{array}{c}\text { 민관 } \\
\text { 협력 } \\
\text { (NGO, } \\
\text { 기업) }\end{array}$} & \multirow[b]{2}{*}{$\begin{array}{l}\text { 행정 } \\
\text { 비용 }\end{array}$} & \multirow[b]{2}{*}{ 기타 } & \multirow[b]{2}{*}{$\begin{array}{l}\text { 순수 } \\
\text { 다자* }\end{array}$} \\
\hline & & & & & 연수 & $\begin{array}{l}\text { 장학 } \\
\text { 지원 }\end{array}$ & 봉사단 & $\begin{array}{l}\text { 기타 } \\
\text { 기술 } \\
\text { 협력 }\end{array}$ & & & & \\
\hline \multirow{2}{*}{ '17년 } & 1.5 & - & $-\ldots$ & - & 0.3 & $-\ldots$ & 1.1 & 0.1 & - & - & - & - \\
\hline & 100 & - & $\because$ & - & 18.7 & - & 75.3 & 6.0 & - & $\begin{array}{l}\cdots \\
-\end{array}$ & - & $\because$ \\
\hline '18년 & 1.6 & - & - & - & 0.3 & - & - & 1.3 & - & - & - & - \\
\hline (요구) & 100 & - & $\begin{array}{l}\cdots \\
-\end{array}$ & - & 19.4 & $\begin{array}{l}\cdots \\
-\end{array}$ & 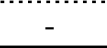 & 80.6 & - & $\begin{array}{l}\cdots \\
-\end{array}$ & - & $\begin{array}{l}\cdots \\
-\end{array}$ \\
\hline
\end{tabular}

* 다자성양자를 제외한 순수다자만 해당되며, 다자성양자는 사업 유형에 맞게 분류

$\square$ 총 사업 목록

\begin{tabular}{l|c|c|r|r|r|r|r|c|c}
\hline & 세부사업명 & 내역사업명 & 사업 유형 & $\begin{array}{c}\text { 총사업 예산 } \\
\text { (억원) }\end{array}$ & $\begin{array}{c}18 \text { 년예산 } \\
\text { (억원) }\end{array}$ & $\begin{array}{c}\text { 신규/ } \\
\text { 계속 }\end{array}$ & $\begin{array}{c}\text { 총사업 } \\
\text { 기간 }\end{array}$ & $\begin{array}{c}\text { 구분 } \\
\text { (양.다자) }\end{array}$ & $\begin{array}{c}\text { SDGs } \\
\text { 목표 }\end{array}$ \\
\hline 1 개도국 기술 지원 $\begin{array}{l}\text { 개도국 경쟁당국 } \\
\text { 직원 인턴십 }\end{array}$ & 연수사업 & 0.30 & 0.30 & 신규 & 1 년 & 양자무상 & 17 \\
\hline 2 & 개도국 기술 지원 $\begin{array}{l}\text { 개도국 경쟁당국 } \\
\text { 전문관 파견 }\end{array}$ & $\begin{array}{c}\text { 기타기술 } \\
\text { 협력 }\end{array}$ & 0.10 & 0.10 & 신규 & 1 년 & 양자무상 & 17 \\
\hline 3 개도국 기술 지원 & $\begin{array}{l}\text { UNCTAD 전문관 } \\
\text { 파견 }\end{array}$ & $\begin{array}{c}\text { 기타기술 } \\
\text { 협력 }\end{array}$ & 1.15 & 1.15 & 계속 & $2016-2018$ & 다자성양자 & 17 \\
\hline
\end{tabular}


$\square$ 총괄

(단위: 억원)

\begin{tabular}{l|c|c|c||c|c|c}
\hline \multirow{2}{*}{$\mathrm{ODA}$ 시행부처(기관) } & \multicolumn{3}{|c||}{2017} & \multicolumn{3}{c}{2018 (요구) } \\
\cline { 2 - 7 } & 양자 무상 & 다자 & 합계 & 양자 무상 & 다자 & 합계 \\
\hline 국민권익위원회 & 0.8 & - & 0.8 & 1.0 & - & 1.0 \\
\hline
\end{tabular}

※ 다자성양자는 양자에 포함

○ '18년도 ODA 시행목표

- 우리의 반부패 정책 및 경험 공유를 통해 개도국과의 상호교류관계를 증진하고, 반부패 제도 구축 및 역량강화를 지원하여 개도국 사회 전반의 부패수준 감소에 기여

으주요 정책과제

- 개도국 공무원의 반부패 역량강화

- 개도국 사회 전반에 우수 반부패 제도 구축

이티타

- 반부패 협력 $\mathrm{MOU}$ 체결(인도네시아, 베트남, 몽골, 튀니지)

$\square$ 유형별 분류

(억원, \%)

\begin{tabular}{|c|c|c|c|c|c|c|c|c|c|c|c|c|}
\hline \multirow[b]{2}{*}{ 구분 } & \multirow[b]{2}{*}{ 계 } & \multirow[b]{2}{*}{ 프로 } & \multirow[b]{2}{*}{$\begin{array}{l}\text { 프로 } \\
\text { 그램 }\end{array}$} & \multirow[b]{2}{*}{$\begin{array}{l}\text { 개발 } \\
\text { 컨설팅 }\end{array}$} & \multicolumn{4}{|c|}{ 기술협력 } & \multirow{2}{*}{$\begin{array}{c}\text { 민관 } \\
\text { 협력 } \\
\text { (NGO, } \\
\text { 기업) }\end{array}$} & \multirow[b]{2}{*}{$\begin{array}{l}\text { 행정 } \\
\text { 비용 }\end{array}$} & \multirow[b]{2}{*}{ 기타 } & \multirow[b]{2}{*}{$\begin{array}{l}\text { 순수 } \\
\text { 다자* }\end{array}$} \\
\hline & & & & & $\begin{array}{l}\text { 연수 } \\
\text { 사업 }\end{array}$ & $\begin{array}{l}\text { 장학 } \\
\text { 지원 }\end{array}$ & $\begin{array}{l}\text { 봉사단 } \\
\text { 파견 }\end{array}$ & $\begin{array}{l}\text { 기타 } \\
\text { 기술 } \\
\text { 협력 }\end{array}$ & & & & \\
\hline \multirow{2}{*}{ '17년 } & 0.8 & $\therefore$ & - & - & 0.6 & - & $\therefore$ & 0.2 & - & - & - & - \\
\hline & 100 & - & - & - & 77.8 & - & - & 22.2 & $\begin{array}{l}\cdots \\
-\end{array}$ & - & - & - \\
\hline '18년 & 1.0 & - & - & - & 0.9 & - & - & 0.1 & - & - & - & - \\
\hline (요구) & 100 & - & - & - & 87.5 & - & - & 12.5 & - & - & - & - \\
\hline
\end{tabular}

* 다자성양자를 제외한 순수다자만 해당되며, 다자성양자는 사업 유형에 맞게 분류

$\square$ 총 사업 목록

\begin{tabular}{|c|c|c|c|c|c|c|c|c|c|}
\hline & 세부사업명 & 내역사업명 & 사업 유형 & $\begin{array}{l}\text { 총사업 예산 } \\
\text { (억원) }\end{array}$ & $\begin{array}{l}\text { '18년예산 } \\
\text { (억원) }\end{array}$ & $\begin{array}{l}\text { 신규/ } \\
\text { 계속 }\end{array}$ & $\begin{array}{l}\text { 총사업 } \\
\text { 기간 }\end{array}$ & \begin{tabular}{|c|} 
구분 \\
(양-다자)
\end{tabular} & $\begin{array}{l}\text { SDGS } \\
\text { 목표 }\end{array}$ \\
\hline 1 & 반부패기술지원 & \begin{tabular}{|l|} 
반부패 역량 강화 지 \\
원(인도네시아)
\end{tabular} & 기타기술협력 & 0.30 & 0.13 & 계속 & $\begin{array}{c}\text { 2016년 20 } \\
\text { 18년 }\end{array}$ & 양자무상 & 16 \\
\hline 2 & 반부패기술지원 & $\begin{array}{l}\text { 반부패 역량 강화 지 } \\
\text { 원(베트남) }\end{array}$ & 연수사업 & 0.17 & 0.03 & 계속 & $\begin{array}{c}\text { 2016년 20 } \\
\text { 18년 }\end{array}$ & 양자무상 & 16 \\
\hline 3 & 반부패기술지원 & $\begin{array}{l}\text { 반부패 역량 강화 지 } \\
\text { 원(몽골) }\end{array}$ & 연수사업 & 0.20 & 0.03 & 신규 & $\begin{array}{c}\text { 2016년 20 } \\
\text { 19년 }\end{array}$ & 양자무상 & 16 \\
\hline 4 & 반부패기술지원 & $\begin{array}{l}\text { 반부패 역량 강화 지 } \\
\text { 원(튀니지) }\end{array}$ & 연수사업 & 0.21 & 0.21 & 신규 & $\begin{array}{c}\text { 2016년 20 } \\
\text { 18년 }\end{array}$ & 양자무상 & 16 \\
\hline 5 & 반부패기술지원 & \begin{tabular}{|l|} 
외국공무원 대상 청렴 \\
교육과정 운영
\end{tabular} & 연수사업 & 0.64 & 0.64 & 신규 & 2018 & 양자무상 & 16 \\
\hline
\end{tabular}




\section{중앙선거관리위원회 2018년도 ODA 예산 계획[안]}

$\square$ 총괄

(단위: 억원)

\begin{tabular}{c|c|c|c||c|c|c}
\hline \multirow{2}{*}{$\mathrm{ODA}$ 시행부처(기관) } & \multicolumn{3}{|c||}{2017} & \multicolumn{3}{c}{2018 (요구) } \\
\cline { 2 - 7 } & 양자 무상 & 다자 & 합계 & 양자 무상 & 다자 & 합계 \\
\hline 중앙선거관리위원회 & 47.7 & - & 47.7 & 68.5 & - & 68.5 \\
\hline
\end{tabular}

※ 다자성양자는 양자에 포함

○ '18년도 ODA 시행목표

- 후발민주주의 국가의 지속가능한 발전을 위한 민주주의·선거분야 지원

으주요 정책과제

- 투명하고 신뢰할 수 있는 민주적 선거기반 조성을 위한 선거 ICT 지원

- 자유롭고 공정한 선거문화 확립을 위한 역량강화 추진

$\square$ 유형별 분류

\begin{tabular}{|c|c|c|c|c|c|c|c|c|c|c|c|c|}
\hline \multirow[b]{2}{*}{ 구분 } & \multirow[b]{2}{*}{ 계 } & \multirow[b]{2}{*}{$\begin{array}{l}\text { 프로 } \\
\text { 젝트 }\end{array}$} & \multirow[b]{2}{*}{$\begin{array}{l}\text { 프로 } \\
\text { 그램 }\end{array}$} & \multirow[b]{2}{*}{$\begin{array}{l}\text { 개발 } \\
\text { 컨설팅 }\end{array}$} & \multicolumn{4}{|c|}{ 기술협력 } & \multirow{2}{*}{$\begin{array}{c}\text { 민관 } \\
\text { 협력 } \\
\text { (NGO, } \\
\text { 기업) }\end{array}$} & \multirow[b]{2}{*}{$\begin{array}{l}\text { 행정 } \\
\text { 비용 }\end{array}$} & \multirow[b]{2}{*}{ 기타 } & \multirow[b]{2}{*}{$\begin{array}{l}\text { 순수 } \\
\text { 다자* }\end{array}$} \\
\hline & & & & & $\begin{array}{l}\text { 연수 } \\
\text { 사업 }\end{array}$ & $\begin{array}{l}\text { 장학 } \\
\text { 지원 }\end{array}$ & $\begin{array}{l}\text { 봉사단 } \\
\text { 파견 }\end{array}$ & $\begin{array}{l}\text { 기타 } \\
\text { 기술 } \\
\text { 협력 }\end{array}$ & & & & \\
\hline \multirow{2}{*}{ '17년 } & 47.7 & 36.6 & - & 1.4 & 9.7 & - & - & - & $-\therefore$ & - & - & - \\
\hline & 100 & 76.8 & - & 2.9 & 20.3 & - & - & - & - & - & - & - \\
\hline '18년 & 68.5 & 31.1 & - & 1.8 & 32.0 & - & - & 3.6 & - & - & - & - \\
\hline (요구) & 100 & 45.4 & - & 2.6 & 46.7 & - & - & 5.3 & - & - & - & - \\
\hline
\end{tabular}

* 다자성양자를 제외한 순수다자만 해당되며, 다자성양자는 사업 유형에 맞게 분류

$\square$ 총 사업 목록

\begin{tabular}{|c|c|c|c|c|c|c|c|c|c|}
\hline & 세부사업명 & 내역사업명 & 사업 유형 & $\begin{array}{c}\text { 총사업예산 } \\
\text { (억원) }\end{array}$ & $\begin{array}{l}\text { '18년예산 } \\
\text { (억원) }\end{array}$ & $\begin{array}{l}\text { 신규/ } \\
\text { 계속 }\end{array}$ & $\begin{array}{l}\text { 총사업 } \\
\text { 기간 }\end{array}$ & $\begin{array}{c}\text { 구분 } \\
\text { (양-다자) }\end{array}$ & $\begin{array}{l}\text { SDGs } \\
\text { 목표 }\end{array}$ \\
\hline 1 & 한국선거제도해외전파 & $\begin{array}{l}\text { 제7회 } \\
\text { 전국동시지방선거 } \\
\text { 禀제선거참관 } \\
\text { 프로그램 운영 }\end{array}$ & 연수사업 & 4.72 & 4.72 & 신규 & 2018년 & 양자무상 & 16 \\
\hline 2 & $\begin{array}{l}\text { 외국시민교육관계자 } \\
\text { 연수 }\end{array}$ & $\begin{array}{l}\text { 외국시민교육관계자 } \\
\text { 연수 }\end{array}$ & 연수사업 & 1.70 & 1.70 & 신규 & 2018년 & 양자무상 & 17 \\
\hline 3 & $\begin{array}{l}\text { 파푸아뉴기니 } \\
\text { 선거관리 선진화사업 }\end{array}$ & $\begin{array}{l}\text { 파푸아뉴기니 } \\
\text { 선거관리 선진화사업 }\end{array}$ & 프로젝트 & 17.90 & 16.37 & 신규 & $2018 \sim 2019$ & 양자무상 & 16 \\
\hline 4 & $\begin{array}{l}\text { 상ㅁㅇㅇㅏ 선거관리 } \\
\text { 선진화사업 }\end{array}$ & $\begin{array}{l}\text { 삼ㅁㅇㅇㅏ 선거관리 } \\
\text { 선진화사업 }\end{array}$ & 프로젝트 & 22.67 & 11.60 & 신규 & 2018 2021 & 양자무상 & 16 \\
\hline 5 & $\begin{array}{l}\text { 기니 선거관리 } \\
\text { 선진화사업 }\end{array}$ & $\begin{array}{l}\text { 긴니 선거관리 } \\
\text { 선진화사업 }\end{array}$ & 개발컨설팅 & 1.79 & 1.79 & 신규 & 2018 & 양자무상 & 16 \\
\hline 6 & $\begin{array}{l}\text { 피지공화국 투·개표 } \\
\text { 선진화를 통한 선거 } \\
\text { 관리 역량강화사업 }\end{array}$ & $\begin{array}{l}\text { 피지공화국 투·개표 } \\
\text { 선진화를 통한 선거 } \\
\text { 관리 역량강화사업 }\end{array}$ & 프로젝트 & 9.85 & 1.59 & 계속 & $2017 \sim 2018$ & 양자무상 & 16 \\
\hline 7 & $\begin{array}{l}\text { 엘살바도르공화국 } \\
\text { 선걷ㄷ 선진화 } \\
\text { 지원사업 }\end{array}$ & $\begin{array}{l}\text { 엘살바도르공화국 } \\
\text { 선걷전ㄴㄴㄴㄴㄴㅎㅘ } \\
\text { 치원사업 }\end{array}$ & 프로젝트 & 17.57 & 1.50 & 계속 & $2017 \sim 2018$ & 양자무상 & 16 \\
\hline 8 & $\begin{array}{l}\text { 선걱관계자 역량강화 } \\
\text { 운수 }\end{array}$ & $\begin{array}{l}\text { 선거관계자 역량강화 } \\
\text { 연수 }\end{array}$ & 연수사업 & 15.61 & 15.61 & 신규 & 2018년 & 양자무상 & 16 \\
\hline 9 & $\begin{array}{l}\text { 엘살바도르의 } \\
\text { 자유로고고ㅇㅓㅓ안 } \\
\text { 선건ㄱㄹ 지원 }\end{array}$ & $\begin{array}{l}\text { 엘살바도르의 } \\
\text { 자율로고 공정한 } \\
\text { 선거관리 지원 }\end{array}$ & 기타기술협력 & 3.62 & 3.62 & 신규 & 2018년 & 양자무상 & 16 \\
\hline & $\begin{array}{l}\text { 선진 선겆제도 도입 } \\
\text { ICT 위륵화 현순서 }\end{array}$ & $\begin{array}{l}\text { 선진 선거제도 도입 } \\
\text { 징원을위한 선거 } \\
\text { ICT 특화 현수 }\end{array}$ & 연수사업 & 10.02 & 10.02 & 신규 & 2018년 & 양자무상 & 16 \\
\hline
\end{tabular}




\section{지방자치단체 2018년도 ODA 예산 계획[안]}

$\square$ 총괄

(단위: 억원)

\begin{tabular}{l|c|c|c||c|c|c}
\hline \multirow{2}{*}{ ODA 시행부처(기관) } & \multicolumn{3}{|c||}{2017} & \multicolumn{3}{c}{2018 (요구) } \\
\cline { 2 - 7 } & 양자 무상 & 다자 & 합계 & 양자 무상 & 다자 & 합계 \\
\hline 지방자치단체 & 102.8 & 22.1 & 124.9 & 113.6 & - & 113.6 \\
\hline
\end{tabular}

※ 다자성양자는 양자에 포함

유형별 분류

(억원, \%)

\begin{tabular}{|c|c|c|c|c|c|c|c|c|c|c|c|c|}
\hline \multirow[b]{2}{*}{ 구분 } & \multirow[b]{2}{*}{ 계 } & \multirow[b]{2}{*}{$\begin{array}{l}\text { 프로 } \\
\text { 젝트 }\end{array}$} & \multirow[b]{2}{*}{$\begin{array}{l}\text { 프로 } \\
\text { 그램 }\end{array}$} & \multirow[b]{2}{*}{$\begin{array}{l}\text { 개발 } \\
\text { 컨설팅 }\end{array}$} & \multicolumn{4}{|c|}{ 기술협력 } & \multirow{2}{*}{$\begin{array}{c}\text { 민관 } \\
\text { 협력 } \\
\text { (NGO, } \\
\text { 기업) }\end{array}$} & \multirow[b]{2}{*}{$\begin{array}{l}\text { 행정 } \\
\text { 비용 }\end{array}$} & \multirow[b]{2}{*}{ 기타 } & \multirow[b]{2}{*}{$\begin{array}{l}\text { 순수 } \\
\text { 다자* }\end{array}$} \\
\hline & & & & & $\begin{array}{l}\text { 연수 } \\
\text { 사업 }\end{array}$ & $\begin{array}{l}\text { 장학 } \\
\text { 지원 }\end{array}$ & $\begin{array}{l}\text { 봉사단 } \\
\text { 파견 }\end{array}$ & $\begin{array}{l}\text { 기타 } \\
\text { 기술 } \\
\text { 협력 }\end{array}$ & & & & \\
\hline \multirow{2}{*}{ '16년 } & 124.9 & 61.3 & - & - & 26.5 & 5.6 & 3.2 & 0.5 & - & - & 5.7 & 22.1 \\
\hline & 100 & 49.1 & - & - & 21.2 & 4.5 & 2.5 & 0.4 & - & - & 4.6 & 17.7 \\
\hline '17년 & 113.6 & 57.9 & - & - & 17.5 & 5.7 & 3.2 & 1.3 & 4.6 & - & 23.3 & - \\
\hline (요구) & 100 & 51.0 & $\begin{array}{l}\cdots \\
-\end{array}$ & - & 15.4 & 5.0 & 2.8 & 1.1 & 4.1 & - & 20.5 & - \\
\hline
\end{tabular}

*다자성양자를 제외한 순수다자만 해당되며, 다자성양자는 사업 유형에 맞게 분류

$\square$ 총 사업 목록

\begin{tabular}{|c|c|c|c|c|c|c|c|c|c|c|}
\hline & 시도 & 세부사업명 & 내역사업명 & 사업 유형 & $\begin{array}{l}\text { 총사업예산 } \\
\text { (억원) }\end{array}$ & $\begin{array}{l}\text { 18년예산 } \\
\text { (억원) }\end{array}$ & $\begin{array}{l}\text { 신규/ } \\
\text { 계속 }\end{array}$ & $\begin{array}{l}\text { 총사업 } \\
\text { 기간 }\end{array}$ & $\begin{array}{c}\text { 구분 } \\
\text { (양-다자) }\end{array}$ & $\begin{array}{l}\text { SDGs } \\
\text { 목표 }\end{array}$ \\
\hline 1 & 서울 & $\begin{array}{l}\text { 불용소방차량 개도국 } \\
\text { 지원 }\end{array}$ & $\begin{array}{l}\text { 불용소방차량 개도국 } \\
\text { 지원 }\end{array}$ & 기타기술협력 & 4.50 & 0.90 & 신규 & 2016-2022 & 양자무상 & 9 \\
\hline 2 & 서울 & $\begin{array}{l}\text { 페루 찬차마요시 수 } \\
\text { 도시설 개선사업 }\end{array}$ & $\begin{array}{l}\text { 수도시설 개선사업 } \\
\text { (정수장, 취수장, 배 } \\
\text { 급수관로) }\end{array}$ & 프로젝트 & 2.94 & 2.94 & 계속 & 2018 & 양자무상 & 6 \\
\hline 3 & 서울 & 서울혁신파크 운영 & $\begin{array}{l}\text { 해외 혁신기관 협력 } \\
\text { 사업 추진 }\end{array}$ & 프로젝트 & 2.00 & 2.00 & 신규 & 2018 & $\begin{array}{c}\text { 다자성양 } \\
\text { 자 }\end{array}$ & 11 \\
\hline 4 & 부산 & $\begin{array}{l}\text { 아세안 공무원 초청 } \\
\text { 시정연수 }\end{array}$ & $\begin{array}{l}\text { 아세안 공무원 초청 } \\
\text { 시정연수 }\end{array}$ & 연수사업 & 0.25 & 0.25 & 신규 & 2018 & 양자무상 & 9 \\
\hline 5 & 부산 & $\begin{array}{l}\text { ODA관계자 국제 초 } \\
\text { 청연수 }\end{array}$ & $\begin{array}{l}\text { ODA관계자 국제 초 } \\
\text { 청연수 }\end{array}$ & 연수사업 & 0.65 & 0.65 & 신규 & 2018 & 양자무상 & 9 \\
\hline 6 & 부산 & 부산해외봉사단 파견 & $\begin{array}{l}\begin{array}{l}\text { 부산해외봉사단 파견 } \\
\text { 봉사 }\end{array} \\
\end{array}$ & 봉사단파견 & 0.60 & 0.60 & 신규 & 2018 & 양자무상 & 3 \\
\hline 7 & 대구 & $\begin{array}{l}\text { 새마을운동 전문인력 } \\
\text { 양성사업 }\end{array}$ & $\begin{array}{l}\text { 새마을운동 전문인력 } \\
\text { 양성사업 }\end{array}$ & 장학지원 & 32.00 & 5.00 & 계속 & 2012-2019 & 양자무상 & 1 \\
\hline 8 & 대구 & 해외의료봉사 I & $\begin{array}{l}\text { 개도국 의료보건 봉 } \\
\text { 사 }\end{array}$ & 봉사단파견 & 1.50 & 1.50 & 신규 & 2018 & 양자무상 & 3 \\
\hline 9 & 대구 & 해외의료봉사 II & $\begin{array}{l}\text { 개도국 의료보건 봉 } \\
\text { 사 }\end{array}$ & 봉사단파견 & 0.30 & 0.30 & 신규 & 2018 & 양자무상 & 3 \\
\hline 10 & 대구 & 국제기능봉사활동 & 국제기능봉사활동 & 봉사단파견 & 0.30 & 0.30 & 신규 & 2018 & 양자무상 & 3 \\
\hline 11 & 대구 & $\begin{array}{l}\text { 지역농업대학 개도국 } \\
\text { 유학생 선진농업 체 } \\
\text { 험 }\end{array}$ & $\begin{array}{l}\text { 지역농업대학 개도국 } \\
\text { 유학생 선진농업 체 } \\
\text { 험 }\end{array}$ & 기타기술협력 & 0.40 & 0.40 & 신규 & 2018 & 양자무상 & 2 \\
\hline 12 & 광주 & $\begin{array}{l}\text { 대외인도적지원사업 } \\
\text { 추진 }\end{array}$ & $\begin{array}{l}\text { 아시아(캄보디아)광 } \\
\text { 주진료소 지원 }\end{array}$ & 민관협력 & 2.50 & 0.40 & 계속 & 2013-2018 & 양자무상 & 3 \\
\hline 13 & 광주 & $\begin{array}{l}\text { 대외인도적지원사업 } \\
\text { 추진 }\end{array}$ & $\begin{array}{l}\text { 아시아(네팔)광주진 } \\
\text { 료소 지원 }\end{array}$ & 민관협력 & 0.40 & 0.40 & 신규 & 2018 & 양자무상 & 3 \\
\hline
\end{tabular}




\begin{tabular}{|c|c|c|c|c|c|c|c|c|c|c|}
\hline & 시도 & 세부사업명 & 내역사업명 & 사업 유형 & $\begin{array}{c}\begin{array}{c}\text { 총사업예산 } \\
\text { (억원) }\end{array} \\
\end{array}$ & $\begin{array}{c}18 \text { 년예산 } \\
\text { (억원) }\end{array}$ & $\begin{array}{l}\text { 신규/ } \\
\text { 계속 }\end{array}$ & $\begin{array}{l}\text { 총사업 } \\
\text { 기간 }\end{array}$ & $\begin{array}{c}\text { 구분 } \\
\text { (양-다자) }\end{array}$ & $\begin{array}{l}\mathrm{SDGS} \\
\text { 목표 }\end{array}$ \\
\hline 14 & 인천 & $\begin{array}{l}\text { 아시아권 교류도시 } \\
\text { 의료지원사업 }\end{array}$ & $\begin{array}{l}\text { 아시아권 교류도시 } \\
\text { 의료지원사업 }\end{array}$ & 민관협력 & 0.50 & 0.50 & 신규 & 2018 & 양자무상 & 3 \\
\hline 15 & 인천 & $\begin{array}{l}\text { 몽골 '인천 희망의 } \\
\text { 숲' 조성사업 }\end{array}$ & $\begin{array}{l}\text { 몽골 '인천 희망의 } \\
\text { 숲' 조성사업 }\end{array}$ & 민관협력 & 2.00 & 2.00 & 신규 & 2018 & 양자무상 & 13 \\
\hline 16 & 인천 & $\begin{array}{l}\text { UN ESCAP 국제부 } \\
\text { 담금 지급 }\end{array}$ & $\begin{array}{l}\text { UN ESCAP 국제부 } \\
\text { 담금 지급 }\end{array}$ & 기타 & 23.30 & 23.30 & 계속 & 2018 & $\begin{array}{c}\text { 다자성양 } \\
\text { 자 }\end{array}$ & 8 \\
\hline 17 & 울산 & $\begin{array}{l}\text { 개도국 의료진 초청 } \\
\text { 연수 }\end{array}$ & $\begin{array}{l}\text { 개도국 의료진 초청 } \\
\text { 연수 }\end{array}$ & 연수사업 & 0.09 & 0.09 & 신규 & 2018 & 양자무상 & 3 \\
\hline 18 & 울산 & $\begin{array}{l}\text { 개도국 의료 봉사단 } \\
\text { 파견 }\end{array}$ & $\begin{array}{l}\text { 개도국 의료 봉사단 } \\
\text { 파견 }\end{array}$ & 봉사단파견 & 0.50 & 0.50 & 신규 & 2018 & 양자무상 & 3 \\
\hline 19 & 경기 & 스마트 교실 구축사업 & 스마트 교실 구축사업 & 프로젝트 & 20.00 & 5.00 & 계속 & 2014-2019 & 양자무상 & 4 \\
\hline 20 & 경기 & $\begin{array}{l}\text { 인도네시아 청년인재 } \\
\text { 초청 ICT 역량강화 } \\
\text { 교육 }\end{array}$ & $\begin{array}{l}\text { 인도네시아 청년인재 } \\
\text { 초청 ICT 역량강화 } \\
\text { 교육 }\end{array}$ & 연수사업 & 14.00 & 4.50 & 계속 & 2016-2018 & 양자무상 & 8 \\
\hline 21 & 강원 & $\begin{array}{l}\text { 지속가능 도시화 역 } \\
\text { 량 강화 }\end{array}$ & $\begin{array}{l}\text { 욱제연수프로그램 } \\
\text { (초청\&현지) }\end{array}$ & 연수사업 & 17.50 & 3.50 & 계속 & 2017 2021 & $\begin{array}{c}\text { 다자성양 } \\
\text { 자 }\end{array}$ & 11 \\
\hline 22 & 강원 & 에티오피아장학사업 & $\begin{array}{l}\text { 한국전 에티오피아 } \\
\text { 참전군 후손 지원사 } \\
\text { 업 }\end{array}$ & 장학지원 & 4.62 & 0.73 & 계속 & $2009 \sim$ & 양자무상 & 4 \\
\hline 23 & 경북 & $\begin{array}{l}\text { 저개발국새마을시범 } \\
\text { 마을조성 }\end{array}$ & $\begin{array}{l}\text { 저개발국새마을시범 } \\
\text { 마을조성 } \\
\text { (에티오피아) }\end{array}$ & 프로젝트 & 51.76 & 4.00 & 계속 & 2010 2018 & 양자무상 & 2 \\
\hline 24 & 경북 & $\begin{array}{l}\text { 저개발국새마을시범 } \\
\text { 마을조성 }\end{array}$ & $\begin{array}{l}\text { 저개발국새마을시범 } \\
\text { 마을조성 } \\
\text { (르완다) }\end{array}$ & 프로젝트 & 41.37 & 4.00 & 계속 & 2010 2018 & 양자무상 & 2 \\
\hline 25 & 경북 & $\begin{array}{l}\text { 저개발국새마을시범 } \\
\text { 마을조성 }\end{array}$ & $\begin{array}{l}\text { 저개발국새마을시범 } \\
\text { 마을조성 } \\
\text { (세네갈) }\end{array}$ & 프로젝트 & 23.00 & 5.00 & 계속 & 2014 2018 & 양자무상 & 2 \\
\hline 26 & 경북 & $\begin{array}{l}\text { 저개발국새마을시범 } \\
\text { 마을조성 }\end{array}$ & $\begin{array}{l}\text { 저개발국새마을시범 } \\
\text { 마을조성 } \\
\text { (코트디부아르) }\end{array}$ & 프로젝트 & 9.00 & 3.00 & 계속 & 2016 2018 & 양자무상 & 2 \\
\hline 27 & 경북 & $\begin{array}{l}\text { 저개발국새마을시범 } \\
\text { 마을조성 }\end{array}$ & $\begin{array}{l}\text { 저개발국새마을시범 } \\
\text { 마을조성 } \\
\text { (필리핀) }\end{array}$ & 프로젝트 & 27.70 & 2.00 & 계속 & 2014 2018 & 양자무상 & 2 \\
\hline 28 & 경북 & $\begin{array}{l}\text { 저개발국새마을시범 } \\
\text { 마을조성 }\end{array}$ & $\begin{array}{l}\text { 저개발국새마을시범 } \\
\text { 마을조성 } \\
\text { (베트남) }\end{array}$ & 프로젝트 & 42.00 & 12.00 & 계속 & 2014 2018 & 양자무상 & 2 \\
\hline 29 & 경북 & $\begin{array}{l}\text { 저개발국새마을시범 } \\
\text { 마을조성 }\end{array}$ & $\begin{array}{l}\text { 저개발국새마을시범 } \\
\text { 마을조성 } \\
\text { (스리랑카) }\end{array}$ & 프로젝트 & 15.50 & 3.50 & 계속 & 2014-2018 & 양자무상 & 2 \\
\hline 30 & 경북 & $\begin{array}{l}\text { 저개발국새마을시범 } \\
\text { 마을조성 }\end{array}$ & $\begin{array}{l}\text { 저개발국새마을시범 } \\
\text { 마을조성 } \\
\text { (인도네시아) }\end{array}$ & 프로젝트 & 22.50 & 6.00 & 계속 & 2015 2018 & 양자무상 & 2 \\
\hline 31 & 경북 & $\begin{array}{l}\text { 저개발국새마을시범 } \\
\text { 마을조성 }\end{array}$ & $\begin{array}{l}\text { 저개발국새마을시범 } \\
\text { 마을조성 } \\
\text { (캄보디아) }\end{array}$ & 프로젝트 & 13.50 & 4.50 & 계속 & 2016 2018 & 양자무상 & 2 \\
\hline 32 & 경북 & $\begin{array}{l}\text { 저개발국새마을시범 } \\
\text { 마을조성 }\end{array}$ & $\begin{array}{l}\text { 저개발국새마을시범 } \\
\text { 마을조성 } \\
\text { (라오스) }\end{array}$ & 프로젝트 & 9.00 & 3.00 & 계속 & 2016 2018 & 양자무상 & 2 \\
\hline 33 & 경북 & $\begin{array}{l}\text { 저개발국새마을연수 } \\
\text { 및보급 }\end{array}$ & $\begin{array}{l}\text { 저개발국새마을연수 } \\
\text { 및보급 }\end{array}$ & 연수사업 & 8.50 & 8.50 & 신규 & 2018 2018 & 양자무상 & 2 \\
\hline 34 & 경남 & $\begin{array}{l}\text { ODA 사업을 통한 } \\
\text { 짐바브웨 보건의료 } \\
\text { 인프라 개선 }\end{array}$ & $\begin{array}{l}\text { ODA 사업을 통한 } \\
\text { 짐바브웨 보건의료 } \\
\text { 인프라 개선 }\end{array}$ & 민관협력 & 4.00 & 1.00 & 계속 & 2015 2018 & 양자무상 & 3 \\
\hline 35 & 경남 & $\begin{array}{l}\text { "world friends PC" } \\
\text { 지원 }\end{array}$ & $\begin{array}{l}\text { “world friends } \mathrm{PC}^{\prime \prime} \\
\text { (네팔) }\end{array}$ & 민관협력 & 0.20 & 0.20 & 신규 & 2018 & 양자무상 & 4 \\
\hline 36 & 경남 & $\begin{array}{l}\text { "world friends PC" } \\
\text { 지원 }\end{array}$ & $\begin{array}{l}\text { "world friends } \mathrm{PC}^{\prime \prime} \\
\text { (탄자니아) }\end{array}$ & 민관협력 & 0.05 & 0.05 & 신규 & 2018 & 양자무상 & 4 \\
\hline 37 & 경남 & \begin{tabular}{|l} 
모자보건 감염관리 \\
제대관리용품 지원
\end{tabular} & $\begin{array}{l}\text { 모자보건 감염관리 } \\
\text { 제대관리용품 } \quad \text { 지원 }\end{array}$ & 민관협력 & 0.05 & 0.05 & 신규 & 2018 & 양자무상 & 3 \\
\hline 38 & 제주 & $\begin{array}{l}\text { 제주-동티모르 우호 } \\
\text { 의 수ㅍㅗㅗ조성 사업 }\end{array}$ & $\begin{array}{l}\text { 제주-동티모르 우호 } \\
\text { 의 숲 조성 사업 }\end{array}$ & 프로젝트 & 3.00 & 1.00 & 계속 & $\begin{array}{l}2017 \sim \\
2019\end{array}$ & 양자무상 & 11 \\
\hline
\end{tabular}

